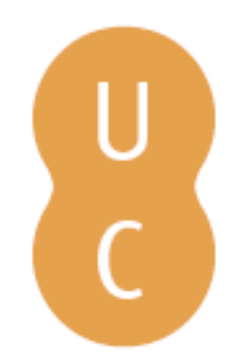

\title{
pompalina
}

\section{Plutarco e as Artes: pintura, cinema e artes decorativas}

$\begin{array}{ll}\text { Autor(es): } & \begin{array}{l}\text { Ferreira, Luísa de Nazaré; Rodrigues, Paulo Simões; Rodrigues, Nuno } \\ \text { Simões }\end{array} \\ \text { Publicado por: } & \begin{array}{l}\text { Centro de Estudos Clássicos e Humanísticos; Imprensa da Universidade } \\ \text { de Coimbra }\end{array} \\ \text { URL } & \text { URI:http://hdl.handle.net/10316.2/2418 } \\ \text { persistente: } & \text { DOI:http://dx.doi.org/10.14195/978-989-8281-57-9 } \\ \text { DOI: } & \text { 26-Apr-2023 12:40:11 } \\ \text { Accessed : } & \end{array}$

A navegação consulta e descarregamento dos títulos inseridos nas Bibliotecas Digitais UC Digitalis, UC Pombalina e UC Impactum, pressupõem a aceitação plena e sem reservas dos Termos e Condições de Uso destas Bibliotecas Digitais, disponíveis em https://digitalis.uc.pt/pt-pt/termos.

Conforme exposto nos referidos Termos e Condições de Uso, o descarregamento de títulos de acesso restrito requer uma licença válida de autorização devendo o utilizador aceder ao(s) documento(s) a partir de um endereço de IP da instituição detentora da supramencionada licença.

Ao utilizador é apenas permitido o descarregamento para uso pessoal, pelo que o emprego do(s) título(s) descarregado(s) para outro fim, designadamente comercial, carece de autorização do respetivo autor ou editor da obra.

Na medida em que todas as obras da UC Digitalis se encontram protegidas pelo Código do Direito de Autor e Direitos Conexos e demais legislação aplicável, toda a cópia, parcial ou total, deste documento, nos casos em que é legalmente admitida, deverá conter ou fazer-se acompanhar por este aviso.

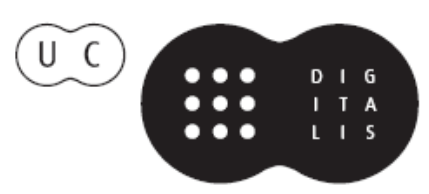


Colecção Autores Gregos e Latinos SÉRIE ENSAIOS

\section{Luísa de Nazaré Ferreira \\ Paulo Simôes Rodrigues Nuno Simões Rodrigues}

\section{Plutarco e as Artes}

Pintura, Cinema e Artes Decorativas

IMPRENSA DA UNIVERSIDADE DE COIMBRA COIMBRA UNIVERSITY PRESS 
(Página deixada propositadamente em branco) 
(Página deixada propositadamente em branco) 
Luísa de Nazaré Ferreira

Universidade de Coimbra

Paulo Simốes Rodrigues

Universidade de Évora

Nuno Simốes Rodrigues

Universidade de Lisboa

\section{Plutarco e as Artes}

Pintura, Cinema e Artes Decorativas

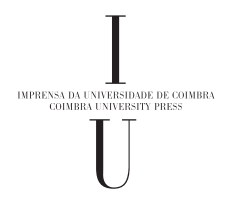


Todos os Volumes desta SÉRIE SÃo SUJeITOS A ARbitragem CIENTÍFICA INDEPENDENTE.

Título - Plutarco e as Artes - Pintura, Cinema e Artes Decorativas Autor - Luísa de Nazaré Ferreira, Paulo Simốes Rodrigues e Nuno Simóes Rodrigues

Série Autores Gregos e Latinos - Estudos

Coordenador Científico do plano de edição: Maria do Céu Fialho

Conselho Editorial

José Ribeiro Ferreira Francisco de Oliveira

Maria de Fátima Silva Nair Castro Soares

Director Técnico: Delfim Leão

\section{Obra realizada no Âmbito das aCtividades da UI\&D \\ Centro de Estudos Clássicos e Humanísticos}

\section{EDIÇÃo}

Imprensa da Universidade de Coimbra

URL: http://www.uc.pt/imprensa_uc

E-mail: imprensa@uc.pt

Vendas online:

http://www.livrariadaimprensa.com

\section{CoORdenAÇÃo EDITORIAL}

Imprensa da Universidade de Coimbra

ConcepçÃo gráfica \& PAginaÇão

Rodolfo Lopes \& Nelson Henrique

Pré-IMPREssão

Imprensa da Universidade de Coimbra
Impressấo e ACABamento

www.artipol.net

ISBN

978-989-26-0280-6

ISBN DigITAL

978-989-26-0291-2

DOI

http://dx.doi.org/10.14195/978-989-8281-57-9

Depósito Legal

$346984 / 12$

1 ${ }^{a}$ EDIÇÃo: $\mathrm{CECH} \bullet 2010$

2a EDIÇÃO: IUC • 2012

(C) JULHO 2012.

IMPRENSA DA UNIVERSIDADE DE CoIMBRA

Classica Digitalia Vniversitatis Conimbrigensis (http://classicadigitalia.uc.pt)

Centro de Estudos Clássicos e Humanísticos da Universidade de Coimbra

Reservados todos os direitos. Nos termos legais fica expressamente proibida a reprodução total ou parcial por qualquer meio, em papel ou em edição electrónica, sem autorizaçáo expressa dos titulares dos direitos. É desde já excepcionada a utilização em circuitos académicos fechados para apoio a leccionação ou extensâo cultural por via de e-learning. 


\section{ÍNDICE}

Introduçấ: Plutarco en el arte

Aurelio Pérez Jiménez (Universidade de Málaga)

A lenda de Aríon e a influênCia de Plutarco na arte OCidental 15

Luísa de Nazaré Ferreira (Universidade de Coimbra)

Bibliografia $\quad 49$

Anexo I 58

Anexo II 65

UM PERCURSO TEMÁTICO NO TEMPO:

As Vidas paralelas de Plutarco e a pintura europeia do século xVI aO SÉculo xix. Primeiras Abordagens.

Paulo Simōes Rodrigues (Universidade de Évora)

Bibliografia $\quad 96$

$\begin{array}{ll}\text { ANEXo I } & 101\end{array}$

Anexo II 115

$\begin{array}{ll}\text { ANEXo III } & 128\end{array}$

LEAST THAT'S WHAT PLUTARCH SAYS

Plutarco no Cinema 139

Nuno Simōes Rodrigues (Universidade de Lisboa)

BIBLIOGRAFIA 238

Anexo 252

$\begin{array}{ll}\text { ÍNDICE DE FONTES ANTIGAS } & 273\end{array}$

$\begin{array}{ll}\text { ÍNDICE REMISSIVO } & 279\end{array}$ 
(Página deixada propositadamente em branco) 


\section{Plutarco en el arte}

Aurelio Pérez Jiménez

(Universidade de Málaga)

En esta época en que se viene produciendo un renacimiento de los estudios sobre la obra de Plutarco y a menudo los estudiosos investigan la influencia del Queronense en la tradición literaria europea y americana, no son frecuentes, sin embargo, las monografías sobre la presencia de los temas de Vidas y Moralia en la iconografía y, en general, en las artes.

Es cierto que hay trabajos parciales sobre el tema, generalmente artículos breves o intervenciones en Simposios y Congresos. Yo mismo he analizado en varias ocasiones la huella de Plutarco en ese arte menor, síntesis de expresión plástica y compendio literario, que es la emblemática ${ }^{1}$ Y el grupo de Siena, dirigido

${ }^{1}$ A. Pérez Jiménez (2003), «Los héroes de Plutarco como modelo en la literatura emblemática europea de los siglos XVI-XVII» in A. Barzano, C. Bearzot, F. Landucci, L. Prandi \& G. Zecchini, Modelli eroici dall'Antichità alla cultura Europea, Roma, L'«Erma di Bretschneider», 375-402; (2003), «El Plutarco de los Moralia en la literatura emblemática hispánica» in G. Fernández Ariza, coord., Literatura Hispanoamericana del Siglo XX. Mimesis e Iconografia, Málaga, Universidad de Málaga, 169-195; (2003), «Las Vidas Paralelas de Plutarco en la emblemática hispánica de los siglos XVI y XVII», Humanitas 55, 223-240; (2005), "Usos didácticos de la imagen y la palabra. El Plutarco de Juan Francisco de Villava» in M. Jufresa, F. Mestre, P. Gómez \& P. Gilabert, eds., Plutarc a la seva època: Paideia i societat (Actas del VIII Simposio Internacional de la Sociedad Española de Plutarquistas, Barcelona, 6-8 nov. 2003), Barcelona, Sociedad Espańola de Plutarquistas, 797-808; (2005), «Los animales de Plutarco en la emblemática europea de los siglos XVI-XVII" in J. Boulogne, ed., Les Grecs de l'Antiquité et les 
por Roberto Guerrini, ha dedicado algunos estudios, artículos y libros, a las ilustraciones en incunables y ediciones humanísticas de las obras plutarqueas y a su influencia en la pintura mural o en las tablas italianas del Renacimiento ${ }^{2}$.

Pero lo que ahora ponemos en manos del lector de lengua portuguesa es distinto. Luisa de Nazaré Ferreira, Paulo Simóes Rodrigues y Nuno Simóes Rodrigues comprometen tres Universidades (la de Coímbra, la de Évora y la de Lisboa) en un proyecto común y ambicioso: desempolvar las imágenes con que se tradujeron las palabras antiguas de Plutarco por los artistas de los tapices, de la pintura mural, de la miniatura, de los lienzos y del cine.

Con este libro se hace justicia al propio Plutarco, tan sensible a las bellas artes en sus descripciones y en sus

animaux. Le cas remarquable de Plutarque, Lille, Université Charlesde-Gaulle-Lille, 63-94; (2005), «Plutarco en Alciato, I», Silva 4, 235-266; y (2006), «Plutarco, Juan de Mal Lara y la Galera Real de D. Juan de Austria» in R. Ma Aguilar \& I. R. Alfageme, eds., Ecos de Plutarco en Europa. De Fortuna Plutarchi Studia Selecta, Madrid, S.E.P.-Universidad Complutense, 233-246. Sobre el mismo tema recordemos también el trabajo de J. L. García Arranz (1996), «La recepción de los escritos animalísticos de Plutarco en los libros de emblemas europeos durante los siglos XVI y XVII» in J. A. Fernández Delgado \& Fca. Pordomingo Pardo, eds., Estudios sobre Plutarco: aspectos formales, Madrid, Ediciones Clasicas, 487-500.

${ }^{2}$ R. Guerrini (1998), «Iconografia di ispirazione plutarchea nell'età dell'Umanesimo" in I. Gallo, ed., L'eredità culturale di Plutarco dall'Antichità al Rinascimento, Napoli, D’Auria, 229-250; R. Guerrini, ed. (2001), Biografia dipinta. Plutarco e l'arte del Rinascimento 1400-1550, Siena/La Spezia, Agorà Edizioni; y M. Caciorgna \& R. Guerrini (2003), La virtù figurata. Eroi ed eroine dell'antichità nell'arte sienese tra Medioevo e Rinascimento, Siena, Alsaba. 
reflexiones ${ }^{3} \mathrm{y}$, además, se les abren nuevas perspectivas a los futuros filólogos. Aproximaciones iconográficas a la obra de Plutarco del estilo de la que presentamos aquí llenan de ilusión a cuantos nos empeñamos en sembrar de cultura clásica una sociedad tan necesitada de ella como es la de nuestra burguesía alejandrina del siglo XXI. Puedo asegurar que Luisa, Paulo y Nuno han sido capaces de transmitirnos esa ilusión.

La primera, avezada filóloga $y$, por tanto, conocedora de la necesidad que tienen los limitados humanos de acotar sus campos de trabajo, se centra en un tema concreto, el de los delfines, que, sin ser de los más habituales de Plutarco ${ }^{4}$, fue bastante querido para los dioses y para los hombres de la Grecia antigua. Con cierta erudición y excelente manejo de las fuentes antiguas y modernas a propósito del simbolismo y de las asociaciones divinas del delfín, la estudiosa de Coímbra nos introduce en las representaciones artísticas del filantrópico animal; y lo hace por su relación con Arión de Metimna y con la historia que contó ya Heródoto y que retoma ahora Gorgo en el Banquete de los siete sabios de Plutarco. Ferreira no se limita al análisis de los pasajes plutarqueos, que sitúa adecuadamente en su tradición literaria; también nos informa cumplidamente de las implicaciones simbólicas del tema y su proyección ya en

${ }^{3}$ Baste citar aquí el libro de R. Hirsch-Luipold (2002), Plutarchs Denken in Bildern, Tübingen, Mohr, o el más reciente, de F. Marín Valdés (2008), Plutarco y el arte de la Atenas hegemónica, Oviedo, Universidad de Oviedo.

${ }^{4}$ Las referencias se limitan, salvo alusiones breves y esporádicas, a Conuiuium Septem Sapientium 161A162B y 163A-C y a De sollertia animalium 984D-985F. 
el arte antiguo, en particular en la cerámica griega y en los mosaicos romanos.

Pero la gran novedad de este trabajo es que, partiendo de la importancia que la historia de Arión y el delfín tuvo en la pintura moderna (desde los frescos del Palacio Ducal de Mantua hasta finales del siglo XX) y en los emblemas (Alciato), llama nuestra atención sobre su presencia en otro arte menor, el de los tapices flamencos e indo-portugueses; y al final nos sorprende con la actualidad artística del texto plutarqueo, recreado musicalmente en la ópera de Alec Roth y Vikram Seth Arion \& the Dolphin, estrenada en junio de 1994.

No menos ambicioso es el trabajo de Paulo Simóes Rodrigues que pasa revista a la presencia de las Vidas Paralelas en la pintura del siglo XVI hasta el XIX. En este caso el estudioso de la Universidad de Évora renuncia a la exhaustividad y, prudentemente, también acota su trabajo y nos lo ofrece como una primera aproximación. Es verdad que a las mencionadas por Rodrigues podrían añadirse más obras de clara influencia plutarquea, sobre todo en lo que se refiere a los siglos XV y XVI; sin embargo, las 174 composiciones catalogadas por él, que se enumeran en los dos apéndices del trabajo, son una muestra más que suficiente de la producción pictórica inspirada en las Vidas Paralelas.

$\mathrm{Y}$ es que existe una larga tradición iconográfica inspirada en la obra de Plutarco, que el autor de este trabajo inicia con las miniaturas francesas del Mestre Luçon, pero que tiene su florecimiento en Italia durante el Quatrocento y el Cinquecento. Allí los héroes 
plutarqueos además de a la miniatura y la ilustración de las primeras ediciones o traducciones de las Vidas, se incorporaron a la pintura mural de abadías, catedrales y palacios. No podemos dejar de mencionar aquí, por ejemplo, las magníficas escenas de la Abadía griega de San Nilo en Grottaferrata, con la historia de Fabio Máximo por Francisco de Siena, que siguen casi ad pedem litterae el texto plutarqueo o las de César y Alejandro en el Palazzo Vitelli alla Cannoniera en Città di Castello.

Sobre esta tradición italiana del Renacimiento los lectores pueden informarse con más detalle en los magníficos trabajos de Roberto Guerrini y sus colaboradores, a los que hemos hecho referencia más arriba; aunque soy consciente de que esta línea de investigación habría superado los intereses, más concretos y aproximativos, en gran medida teóricos, con que Paulo S. Rodrigues ha orientado su propuesta. Por supuesto, la documentación aportada por el autor del trabajo es más que suficiente para ilustrar la visión que cada época (entre 1410 y 1899) tuvo de la historia. De la selección de los personajes y los momentos que reviven en esos cuadros quedan al descubierto las razones por las que las distintas sociedades europeas reclamó unas escenas y no otras y unos héroes y no otros entre los griegos y romanos que engrandecieron Livio, Valerio Máximo, Nepote y, sobre todo, el propio Plutarco.

Como hemos dicho, podrían sumarse más pintores y obras al catálogo que nos ofrece Rodrigues, naturalmente; pero la amplia selección aquí utilizada ya se nos antoja suficiente para el objetivo principal del autor: 
ilustrar los valores que los creadores y los destinatarios de estas obras perseguían en cada período, según eran sus ideales morales, estéticos o incluso políticos.

Por último, el estudioso de Lisboa Nuno Simóes Rodrigues nos acerca más Plutarco a nuestra época, enraizándolo en los siglos XX y XXI con el Séptimo Arte. Como era de esperar, tampoco las Vidas Paralelas han quedado al margen del cine de Griegos y Romanos. Los lectores de Plutarco disfrutarán con la lectura del trabajo de Nuno S. Rodrigues, que es preciso en cuanto a la deuda de estas películas con la obra del Queronense (y no sólo con las Vidas); pero que también es crítico con las inexactitudes de aquellas cintas que buscaban con ellas evitar equívocos ante un público no muy culto, enriquecer melodramáticamente el relato histórico o simplemente potenciar los intereses ideológicos del autor del guión, del director o de la sociedad a la que iba dirigido el filme como medio de propaganda.

Mediante la lectura de este trabajo encontramos nuevas razones para volver a visionar cintas clásicas y modernas de nuestro cine protagonizadas por héroes plutarqueos, principales o no de las Vidas Paralelas. Rodrigues recuerda, analiza y comenta, siguiendo la letra de Plutarco, las principales versiones de historias protagonizadas por Rómulo, Alejandro, César, Antonio y Cleopatra, Coriolano y Espartaco o presentes en obras plutarqueas, como el Rapto de las Sabinas o la Batalla de las Termópilas.

Poco más nos queda que decir. Los tres trabajos reunidos en este libro, querido lector, se leen con fluidez 
y agrado; y, lo más importante, traen a nuestro recuerdo, junto con las imágenes de los cuadros y tapices que ya habíamos visto en los museos, o con las escenas que nos hicieron vibrar alguna vez en las salas de proyección, la frescura de los temas y los héroes de Plutarco. Para mi generación y las anteriores, al menos, es cierto que, como alguien ha dicho 5 , las Vidas Paralelas conformaron junto con la Biblia dos pilares básicos de nuestra cultura occidental. Esperemos que, gracias a libros como éste, que mantienen viva su memoria, así continúe siendo, siquiera en lo que atañe a Plutarco, durante el resto del siglo XXI.

${ }^{5}$ A. M. Martín Rodríguez (2007), «Plutarco y el cine. Los peligros de la imitación automática de los modelos clásicos en Siete novias para siete hermanos» in J. Ma Nieto Ibáñez \& R. López López, El amor en Plutarco, León, Universidad de León, 635. 
(Página deixada propositadamente em branco) 


\title{
A lenda de Aríon e a INfluênCia de Plutarco Na arte ocidental
}

\author{
Luísa de Nazaré Ferreira
}


(Página deixada propositadamente em branco) 


\section{A lenda de Aríon e a influênCia de}

\section{Plutarco na ARTe Ocidental *}

Luísa de Nazaré Ferreira

(Universidade de Coimbra)

\section{Introdução: o golfinho na tradição clássica}

Há muitos séculos que o golfinho integra a galeria dos seres vivos mais amados pelos povos do Mediterrâneo e, quando pensamos na sua representação na cultura clássica, lembramo-nos imediatamente dos famosos frescos minóicos do palácio de Cnossos ${ }^{1}$. Os golfinhos surgem também com grande destaque no enigmático fresco em miniatura da «expedição naval» que decorava a sala 5 da Casa Ocidental do sítio arqueológico de Akrotiri, na antiga Tera (Santorini) ${ }^{2}$. Desde essa época

* Retomamos neste estudo a comunicação apresentada ao $8^{\circ}$ Congresso da International Plutarch Society (Universidade de Coimbra, 23-27 de Setembro de 2008), sob o título «Aríon e o golfinho: marcos literários e artísticos de uma aventura célebre (a propósito de Plu. Sept. sap. conv. 18.160E-19.162B)», a investigação sobre esta matéria que consta da nossa tese de Doutoramento (2005, 57-62) e de um artigo publicado no Boletim de Estudos Clássicos (49, 2008, 21-25). Em anexo (I), além de um poema atribuído a Aríon, citamos as versóes da lenda transmitidas por Heródoto (1.23-24) e Plutarco (O Banquete dos Sete Sábios 160E-162B), traduzidas, respectivamente, por José Ribeiro Ferreira e Delfim Ferreira Leão, a quem expressamos o nosso agradecimento.

${ }^{1}$ Cf. frescos dos golfinhos do «mégaron da Rainha», do Período Neopalaciano (1700 a.C.). Vide Preziosi, Hitchcock (1999) 94-95; http://commons.wikimedia.org/wiki/Image:Crete_knossos_ dolphins.jpg (acedido em 5/07/2010).

${ }^{2}$ Fresco da «expedição naval», de Tera, séc. XVI a.C. Atenas, Museu Nacional. Vide Karouzou (1992) 159, 162-163; 
remota, a presença deste animal torna-se recorrente na arte grega, em especial na pintura de vasos, e com a dupla função que estes dois exemplos ilustram: como simples motivo decorativo - testemunho da admiração que suscitava, da importância da natureza e do mar para os Gregos - e como convenção iconográfica para assinalar a paisagem aquática. Assim, na numismática, aparece habitualmente representado em moedas cunhadas nas cidades com uma forte ligação ao mar, designadamente da Magna Grécia³ .

De acordo com John Boardman (1974, 204), o golfinho é dos poucos animais marinhos que aparece com frequência na decoração do interior ou dos frisos das taças áticas de figuras negras. Um dos exemplos mais antigos é uma taça descoberta em Górdio (Turquia), assinada no exterior pelo pintor Clítias e pelo oleiro Ergotimo (c. 570 a.C.), e decorada no interior com três golfinhos e um peixe ${ }^{4}$. O golfinho é também um motivo ornamental nos skyphoi (vasos para beber) com bandas, fabricados na Ática em meados do século VI a.C. ${ }^{5}$ Merece igualmente destaque uma phiale (vaso para libaçôes), proveniente de Erétria, datada de c. 510-500 a.C., com

http://www.therafoundation.org/akrotiri/thewesthouse/ miniaturefriezeroom5flotilla/view (acedido em 5/07/2010).

${ }^{3}$ E.g. dracma de prata de Zancle, de c. 510 a.C.; tetradracma de prata de Siracusa, de c. 480-470 a.C. Vide Boardman (1990) 198, no 235 e 217 , no 257 , respectivamente.

${ }^{4}$ Berlim, Staatliche Museen (4604). Vide Boardman (1974) $n^{\circ} 108$.

5 Camberra, University House. Vide Boardman (1974) no 132 . 
representaçôes de golfinhos e polvos ${ }^{6}$, que é um belo exemplo do emprego da policromia (branco, vermelho) sobre fundo negro. Nesta técnica de pintura ("técnica de Six»), atestada por um grande número de phiales do final do século VI a.C., provenientes da Acrópole de Atenas, aparecem com frequência motivos marinhos (golfinhos, polvos, embarcaçóes) eflorais, mas raramente personagen ${ }^{7}$.

É provavelmente mais conhecido um lécito ático de figuras negras sobre fundo branco, de c. 500 a.C., atribuído ao Pintor de Edimburgo, que representa Ulisses amarrado ao mastro do navio a escutar uma sereia que executa o duplo aulos pousada numa rocha (uma outra sereia toca lira). No meio destas personagens, um golfinho em plena acrobacia sugere que a cena decorre no alto-mar. A mesma função assumem os golfinhos que aparecem numa hydria ática de figuras vermelhas, atribuída ao Pintor de Berlim, de c. 500-480 a.C., onde vemos o deus Apolo, com a lira na mão, sentado sobre uma trípode elevada ${ }^{8}$. No entanto, se é evidente que os golfinhos estão aqui presentes porque evocam a paisagem marinha, não se pode excluir a ligação destes seres a várias divindades, designadamente ao deus que

6 Paris, Museu do Louvre (L 210). Vide http://commons. wikimedia.org/wiki/File:Phiale_Louvre_L210.jpg (acedido em 15/07/2010).

${ }^{7}$ Boardman (1974) 178-179. A designação de «técnica de Six» (Six's technique) foi adoptada por J. D. Beazley a partir do nome de Jan Six, o primeiro a descrevê-la. Cf. Boardman (1974) no 314, hoje em Viena, Kunsthistorisches Museen (1923).

${ }^{8}$ Respectivamente Atenas, Museu Nacional (CC958); Roma, Museus do Vaticano. Vide Boardman (1975) no 157. 
escolheu para seu espaço sagrado uma terra que se chamava Delfos, nome tão próximo da designação grega do golfinho ou delfim: delphis?.

A relação dos golfinhos com o deus do mar é clara (cf. e.g. Aristófanes, Cavaleiros 560; Ovídio, Fastos 2.81). De acordo com o hino a Poséidon atribuído ao poeta Aríon (vide infra), estes seres são de origem divina, porque foram gerados pela nereide Anfitrite (cf. vv. 1011). E a representação desta figura a ser transportada por um golfinho é um motivo da pintura de vasos sobretudo do final da Época Clássica ${ }^{10}$. A associação a Apolo, porém, parece ter tido um cunho religioso mais forte. No Hino Homérico a Apolo (III), o deus toma a forma de um golfinho para conduzir até às costas de Crisa os cretenses que escolheu para se tornarem sacerdotes do seu templo (vv. 388-439). Plutarco, em Sobre a inteligência dos animais 984A, observa que os Gregos ergueram templos em honra de Apolo Delfínio e que, ao contrário da versão do hino homérico, o deus não mudara de forma, mas enviara um golfinho a guiar os homens até ao porto de Delfos ${ }^{11}$.

9 Esta proximidade não assegura, todavia, uma relação etimológica, embora P. Chantraine observe que o epíteto Delphinios, atestado no Hino Homérico a Apolo 3.495, podia ser interpretado como "deus do delfim", mas também como "deus de Delfos» (Dictionnaire étymologique de la langue grecque. 1-2. Paris, Klincksieck, 1990, s.v. delphis).

${ }^{10}$ E.g. taça de figuras vermelhas do terceiro quartel do séc. IV a.C., proveniente da Itália do sul. S. Petersburgo, Museu do Hermitage. Vide http://www.hermitagemuseum.org/html_ En/04/2009/hm4_2_288_2.html (acedido em 15/07/2010).

${ }^{11} \mathrm{O}$ culto em honra de Apolo Delfínio é atestado por outras fontes, e.g. Hino Homérico a Apolo 3.495; Aristóteles, Constituição 
Da ligação deste animal ao deus do vinho e do teatro dão testemunho quer a literatura quer a pintura de vasos áticos, como documenta a célebre taça de figuras negras assinada por Exéquias c. 530 a.C. ${ }^{12}$ No exterior exibe o motivo dos olhos grandes, talvez inventado pelo próprio artista. A decoração do interior relaciona-se certamente, como julgam vários estudiosos, com o tema central do VIIo Hino Homérico, dedicado a Diónisos, que M. West $(2003,16)$ data do final da Época Arcaica. Nele se relata como o deus, confundido com um príncipe, foi raptado por piratas ${ }^{13}$. No entanto, estes assustam-se com os prodígios do filho de Zeus, atiram-se ao mar e são transformados em golfinhos (v. 53). Diónisos salvou deste destino o timoneiro que, desde o início, demonstrara grande piedade e se opusera, em vão, à violência dos companheiros (vv. 17-24). A metamorfose é assim, ao mesmo tempo, o castigo imposto aos homens que não foram capazes de detectar os sinais de divindade do passageiro acolhido a bordo, mas é também um símbolo de redenção,

dos Atenienses 57.3; Plutarco, Vida de Teseu 14.1. Vide Schamp (1976) 100-103.

12 Munique, Staatliche Antikensammlungen (2044). Vide Boardman (1974) 57-58, no 104; Robertson (1978) 71-72; Woodford (1986) 25-26, fig. 24; Moore (1987) 154-155; Boardman (2001) 283-284, no 309; http://commons.wikimedia.org/wiki/ File:Exekias_Dionysos_Staatliche_Antikensammlungen_2044.jpg (acedido em 15/07/2010).

${ }^{13}$ West (2003) 16 nota que Píndaro alude a este mito (fr. 236 Maehler) e supóe que o hino homérico não deve ter sido composto muito antes do tempo do poeta de Tebas, que terá nascido c. 518 a.C. Outros estudiosos não excluem uma data de composição mais antiga (séc. VII ou VI a.C.). Cf. Evelyn-White (1936) xxxviii-xxxix. 
uma vez que os poupa da morte e de uma vida de maldade.

A taça de Exéquias representa o deus do vinho reclinado majestosamente num barco cujo mastro sustenta (ou é ele próprio) uma magnífica videira, o que parece ser a ilustração de um dos prodígios referidos no hino homérico (vv. 38-42) ${ }^{14}$. À volta do barco, formando um círculo completo com os ramos da videira e os cachos de uvas, o artista dispôs sete golfinhos em harmoniosa simetria, uns voltados para a direita, outros para a esquerda, e assim concedeu à pintura a ilusão de movimento. Dois golfinhos muito mais pequenos figuram na decoração do barco que acolhe, à semelhança de um leito do symposion, o corpo reclinado do deus. Como bem notou M. H. Rocha Pereira (2009, 19), outro elemento singular desta composição é o branco da vela desfraldada, que se destaca do fundo vermelho da taça.

É bem possível, como supôs M. West (2003, 17), que a qualidade excepcional desta pintura tenha inspirado o mito e não o contrário ${ }^{15}$. Certo é que a peça

${ }^{14}$ «E logo, ao longo do bordo mais alto da vela, estendem-se / ramos de videira, daqui e dali, e pendem inúmeros / cachos. Em volta do mastro, negra, coleava uma hera, / a proliferar flores, e nela cresciam os gratos frutos. / Todos os escalmos tinham grinaldas. (...)» - Tradução de Ferreira (2006) 21-23.

${ }^{15} \mathrm{O}$ mito dos piratas transformados em golfinhos por Diónisos foi também referido na Biblioteca atribuída a Apolodoro (3.5.3), por Ovídio (Metamorfoses 3.581-691) e Higino (Fabulae 134, De Astronomia 2.17). Luciano evoca-o brevemente nos Diálogos dos deuses marinhos 5 . No séc. IV a.C., a lenda foi representada nos relevos do monumento corégico de Lisícrates, que celebrou a vitória como patrocinador dos espectáculos de teatro (choregos) no 
confirma que os golfinhos se tornaram a pouco e pouco elementos indissociáveis da paisagem marítima. Além desse motivo artístico, tal como o hino homérico, a pintura documenta a relação destes seres amistosos com Diónisos.

Se desde muito cedo surgiu entre os Gregos a ideia de que existe um vínculo especial entre os golfinhos e algumas divindades, a imagem do golfinho que salva das águas seres humanos e com eles cria laços de amizade, em especial com os mais jovens, torna-se familiar ao imaginário clássico pelo menos desde a Época Arcaica. Parece datar desse período uma estatueta em bronze, possivelmente votiva, proveniente das escavaçóes na Acrópole de Atenas, que representa um rapaz sobre o dorso de um golfinho ${ }^{16}$. O facto de este animal surgir na cultura clássica associado à ideia de salvação, habitualmente numa situação limite, explica que mais tarde, na iconografia cristá primitiva, venha a ser também entendido como representação simbólica da fé e, ainda que mais raramente, do Cristo Salvador ${ }^{17}$.

ano de 334 a.C. Vide Boardman (1995) 27, no 16.

16 Atenas, Museu Nacional (6626). Vide Karouzou (1992) 110.

${ }^{17} \mathrm{O}$ golfinho como símbolo cristão suscita várias interpretaçôes: o amor e a ternura que une os homens; o golfinho acompanha os barcos e pode representar Cristo que guia os crentes na sua fé; a velocidade dos golfinhos pode ser um símbolo do desejo com que os devotos se dedicam a Cristo, depois de o conhecerem; na arte cristã também é representado a transportar as almas dos mortos para o Além; ao lado de uma âncora ou barco simboliza a alma de Cristo ou a Igreja; o golfinho pode também evocar a história de Jonas (Jn 1.2), sendo assim um símbolo de ressurreição. Cf. Impelluso (2004) 305. 
Provavelmente com razão, defendem alguns estudiosos que este simbolismo deriva principalmente do relato do salvamento do poeta Aríon transmitido por Plutarco no Banquete dos Sete Sábios, que comentaremos adiante ${ }^{18}$.

\section{A lenda de Aríon na Antiguidade: fontes literárias e iconográficas}

Se nos demorámos nestas considerações iniciais é porque esta tradiçáo mitológica e iconográfica explica, em parte, a perenidade da história de Aríon como tema literário e artístico, bem como a variedade de tratamentos que suscitou ao longo de séculos. As fontes literárias mais importantes demonstram que esta lenda mistura, como tantas outras que nos chegaram da Antiguidade, elementos históricos e ficcionais. De facto, o retrato que nos apresenta Heródoto, a nossa fonte mais antiga e talvez mais influente, enquadra-se perfeitamente no contexto poético-musical da Época Arcaica (1.23-24):

- Aríon, natural da ilha de Lesbos (de Metimna), era um executante exímio da arte da cítara e teve um papel decisivo na evolução da forma coral do ditirambo ${ }^{19}$;

- Como se tornou costume na Época Arcaica, este artista fazia da mobilidade um modo de vida (e estava, assim, sujeito aos muitos perigos das viagens), embora tivesse uma relaçáo privilegiada com um patrono poderoso, Periandro, tirano de Corinto entre c. 625

${ }^{18}$ Vide J. Chevalier et A. Gheerbrant (1982), Dictionnaire des Symboles. Paris, Robert Laffont/Jupiter, s.v. dauphin.

19 No que respeita a este assunto, vide Privitera (1988), Zimmermann (1992) 24-29, Ieranò (1992), Ieranò (1997) 187-194, e o nosso estudo (2005) 57-62. 
e 585 a.C., que foi considerado um dos Sete Sábios ${ }^{20}$. Assim, o poeta teria desenvolvido a sua carreira no último quartel do século VII e início do século VI a.C., portanto, em data próxima de Safo e Alceu de Lesbos, e de Estesícoro de Hímera.

Estes dados são corroborados por testemunhos posteriores $^{21}$, mas a fama de Aríon deve-se muito mais ao relato do seu salvamento, que constitui, na verdade, o tema central da digressão de Heródoto sobre o protegido de Periandro.

O historiador começa por esclarecer que a aventura era contada pelos habitantes de Corinto e confirmada pelos de Lesbos $(1.23,1.24 .8)$, do que se depreende que evoca uma tradição popular, que pode ter tido origem num mito de carácter etiológico ou em antigos cultos coríntios ${ }^{22}$. De acordo com o seu relato, Aríon vivera a maior parte da vida na corte de Periandro, mas em determinada altura sentiu vontade de divulgar o seu talento na Magna Grécia e, depois de ganhar muito dinheiro, decidiu regressar a Corinto, a partir

${ }^{20}$ Aríon é o primeiro poeta grego a ser associado à protecção de um tirano, o que se tornará frequente a partir do séc. VI a.C. Periandro de Corinto figura entre os Sete Sábios nas listas transmitidas por Pausânias (10.24.1) e Diógenes Laércio (1.94100), mas não na de Platão (Protágoras 343a).

${ }^{21}$ Cf. Helânico de Lesbos (Lista das vitórias nas Carneias) e Dicearco (Sobre os concursos dionisíacos), citados num escólio de Aristófanes (ad Aves 1403). A Suda (A 3886) situa o floruit do citaredo de Lesbos c. 628/624 a.C. (a Crónica de Eusébio um pouco mais tarde: 619/618 ou 610/609, segundo a versão arménia). Cf. schol. Pind. Ol. 13.25. Os testemunhos sobre Aríon foram reunidos por Campbell (1991) 16-25.

${ }^{22}$ Cf. Bowra (1963) 131-134, Burkert (1983) 199-200; Defradas, Hani, Klaerr (1985) 341. 
de Tarento, num barco de marinheiros coríntios. Estes, porém, levados pela perfídia e pela ambição, projectam matar o ilustre citaredo atirando-o ao mar. Quando viu que as súplicas não os demoviam, Aríon pediu que o deixassem executar uma última melodia. Logo que terminou, lançou-se ao mar e um golfinho tomou-o no dorso e levou-o para o Ténaro, o promontório situado mais ao sul do Peloponeso (actual cabo Matapan). Assim que chegou a Corinto, dirigiu-se ao palácio e relatou a aventura a Periandro que mais tarde interrogou os marinheiros sobre o sucedido (1.24).

Um dos pontos altos da versáo de Heródoto é o momento em que Aríon actua pela última vez. Apresenta-se aos piratas com uma indumentária elaborada, como se participasse num ritual, e executa o nomos orthios, uma melodia citaródica famosa (geralmente em honra de Apolo) de grande exigência vocal $^{23}$. Heródoto insiste no pormenor das vestes solenes e ornamentadas, com as quais o poeta se atira ao mar (1.24.4-5) e, no final, se apresenta perante os piratas (1.24.7), confirmando que a ostentação e elegância do vestuário eram um elemento fundamental da actuaçáo e identidade dos citaredos e de outros cultores das Musas, como testemunham, em especial, os vasos áticos de figuras vermelhas ${ }^{24}$.

${ }^{23}$ Segundo o De musica $1140 \mathrm{~F}$, a melodia órtia havia sido inventada por Terpandro de Lesbos (séc. VII a.C.). A Suda (A 1701) corrobora esta informação e atesta que consistia num hino em honra de Apolo. Da popularidade dá testemunho Aristófanes, Cavaleiros 1279. Vide Gostoli (1993).

${ }^{24}$ E.g. Nova Iorque, The Metropolitan Museum of Art (56.171.38): ânfora atribuída ao Pintor de Berlim, c. 490 a.C. 
O historiador encerra a digressão observando que havia no Ténaro uma oferta votiva de Aríon, em bronze e de pequenas dimensóes, que representava um homem no dorso de um golfinho (1.24.8), monumento que terá sido ainda visto por Pausânias (3.25.7, cf. 9.30.2). Moedas cunhadas em Metimna, a terra natal do poeta, e em Tarento atestam a popularidade da lenda numa vasta área geográfica que vai do Mar Egeu à península itálica ${ }^{25}$.

A popularidade da aventura de Aríon deve-se a Heródoto e a outros autores, como Ovídio (Fastos 2.79-118), Plutarco (O Banquete dos Sete Sábios 160E-162B), Higino (Fabulae 194, De Astronomia 2.17), Luciano (DMar. 5), Aulo Gélio (Noites áticas 16.19, baseado em Heródoto) e Cláudio Eliano (Natureza dos animais 12.45$)^{26}$. Este último escritor, numa compilação de factos extraordinários sobre a fauna, a fim de documentar que os golfinhos são atraídos pelo canto e pelos sons do aulos, cita um dístico elegíaco, supostamente inscrito na estátua de Aríon erguida no Ténaro $^{27}$, e um hino em honra de Poséidon, que teria sido composto pelo poeta, mas que é, provavelmente,

(citaredo); Boston, Museum of Fine Arts (26.61): ânfora atribuída ao Pintor de Brigos, c. 480 a.C. (citaredo); Londres, British Museum (E 270): ânfora atribuída ao Pintor de Cleófrades, c. 490480 a.C. (lado A: rapsodo; lado B: auleta).

${ }^{25}$ Vide Richter (1984) 92-94, Cahn (1984) Arion 2-7, Ferreira (1994) 70 n. 32.

${ }^{26}$ Para um exame da transmissão literária da história de Aríon, vide Schamp (1976).

${ }^{27}$ Vide Page (1981) 499, anon. CLXXVII. Dois poemas da Antologia Grega (AP 9.308 e APl 276) atribuídos a Bianor (séc. I d.C.) atestam a perenidade da tradiçâao. 
uma composição dos fins do século $\mathrm{V}$ a.C. ou mais $\operatorname{tardia}^{28}$. Do talento artístico do citaredo de Metimna não nos chegou nenhuma prova segura. Como bem notou Cláudio Eliano (ibidem), este poema é um canto de agradecimento ao deus do mar e, ao mesmo tempo, retribui a gentileza dos golfinhos que salvaram Aríon. A ideia de que a "melodia sedutora dos auloi» chama a atenção destes animais já é referida num fragmento de Píndaro (fr. 140b.15-17 Maehler) ${ }^{29}$ e terá ecos na literatura da Época Clássica (e.g. Eurípides, Electra 435; Aristófanes, Rãs 1317). Na pintura de vasos, porém, o tema aparece muito mais cedo, como sugere uma taça ática de figuras negras, de c. 560-550 a.C., decorada no interior com três golfinhos, sendo que um tem braços e executa o duplo aulos ${ }^{30}$.

Plutarco introduz a lenda de Aríon no Banquete dos Sete Sábios através da figura de Gorgo, irmão de Periandro. De regresso de uma missão no Ténaro, anseia por contar um prodígio que ele próprio testemunhara (160D): no

${ }^{28} \mathrm{O}$ hino atribuído a Aríon integra actualmente os fragmenta adespota do corpus de poesia lírica grega (fr. $939 P M G$, em anexo). Vide Page (1962) 506-507, Campbell (1993) 360-363. Segundo este editor, trata-se de uma composição de estilo ditirâmbico de c. 400 a.C. (p. 361 n. 3). Para a análise da inscrição e do hino citados por Eliano, vide Bowra (1963) e Schamp (1976) 105-109, especialmente.

${ }^{29} \mathrm{O}$ fragmento de Píndaro foi transmitido por um papiro (P.Oxy. 408) e os vv. 15-17, que se referem à philomousia dos golfinhos, são citados por Plutarco nas Quaestiones convivales (704F-705A) e em De sollertia animalium (984B-C). Vide M Race (1997) 374-377.

30 Roma, Museo Nazionale di Villa Giulia (64698). Vide Lissarague (2000) 139, fig. 5.3. 
decurso de uma festa realizada à noite, à beira-mar, os celebrantes são surpreendidos pela chegada à praia de um grupo de golfinhos que se deslocavam em grande velocidade e transportavam uma figura humana. Logo descobrem que se trata de Aríon, pois, observa Gorgo, além de estar consciente, embora atordoado pela viagem, envergava os trajes que usava nas suas actuaçóes (160E-161B). A indumentária solene do poeta de Lesbos é um elemento relevante na digressão de Heródoto, pois permite denunciar a Periandro a falsidade do discurso dos piratas (1.24.7). No texto de Plutarco, porém, as vestes são os primeiros sinais da dimensão religiosa que envolve o seu salvamento. É que, como explicará Gorgo, quando Aríon se deu conta do perigo em que se encontrava teve uma espécie de inspiração divina que o levou a apresentar-se perante os seus assassinos envergando um traje solene, como se de uma veste fúnebre se tratasse, preparado para uma última actuação (161B-C). Também neste ponto o texto de Plutarco introduz uma ligeira diferença em relação a Heródoto, sublinhando a devoçáo religiosa do citaredo, quese propóe cantar o nomos pythicos, uma composição que evocava expressivamente a luta de Apolo contra a serpente Píton (cf. Schamp 1976, 116). Segue-se o momento fulcral desta versão, a descrição dos sentimentos e emoçôes que Aríon experimenta quando é erguido das águas, ainda antes de ter mergulhado completamente (161D). A pouco e pouco, convence-se de que se salvava por ser amado pelos deuses (theophiles aner) e que os golfinhos não eram mais do que intermediários da divindade 
(161E-162A). Na parte final da sua intervenção, Gorgo confirmará que o salvamento prodigioso do poeta era obra da intervenção divina (162B).

Por conseguinte, embora a influência de Heródoto esteja subjacente ao longo de todo o passo, não se trata agora de um conto popular transmitido pela tradição oral, mas de um acontecimento recente testemunhado por uma pessoa da confiança de Periandro. Ao dar a palavra a um dos convivas do banquete, Plutarco compôs uma versão mais pitoresca, que póe em destaque os momentos cruciais do salvamento de Aríon, designadamente a actuação perante os piratas e o transporte para terra, com todos os ornamentos, por um grande número de golfinhos velozes que se deslocam com movimentos sincronizados. É também evidente que nas Histórias de Heródoto a digressão sobre Aríon surge pela associação do famoso citaredo com Periandro ${ }^{31}$, enquanto no Banquete dos Sete Sábios a exposição de Gorgo é um testemunho emocionante da intervenção da divindade no mundo dos homens. Esta ideia será corroborada na parte final do tratado quando, após a narração de outras histórias extraordinárias sobre o comportamento amistoso dos golfinhos ${ }^{32}$, Anacársis

${ }^{31}$ Sobre as motivaçóes de Heródoto para narrar a história de Aríon, vide Hooker (1989); cf. Gray (2001); para uma análise do conteúdo filosófico-didáctico deste logos, vide Soares (2003) 96-101.

32 Sólon expôe o relato da morte de Hesíodo e como, graças aos golfinhos, o seu corpo, lançado ao mar pelos assassinos, foi resgatado e sepultado junto do templo de Zeus Nemeu (162C-F). Pítaco relata em seguida o salvamento de Énalo e da amada (163A-D). 
observar que as mais belas coisas se cumprem por vontade divina (163D).

A difusão da aventura de Aríon na Antiguidade deve-se em primeiro lugar a Heródoto, como notaram Estrabão (13.2.4) e Aulo Gélio (16.19.1), enquanto o papel da iconografia parece ter sido bastante menor, pois, além da numismática, a que já nos referimos, apenas nos chegaram representaçóes em mosaicos da Época Romana. Destaca-se, em especial, uma decoração da villa romana de Piazza Armerina (século IV d.C.) ${ }^{33}$, que podia ilustrar os versos de Ovídio (Fast. 2.115-116) sobre o momento em que Aríon é resgatado das águas:

ille sedens citharamque tenet pretiumque uehendi cantat et aequoreas carmine mulcet aquas.

Ele, sentado, segura a cítara e pelo favor do transporte canta e com seu canto acalma as águas do mar.

As duas histórias são evocadas em Sobre a inteligência dos animais 969E, 984D (Hesíodo), e 984E (Énalo, também em Ateneu $11.466 \mathrm{c}-\mathrm{d})$, num passo em que Plutarco relata outros salvamentos de pessoas por golfinhos. O escritor refere neste tratado (985B) que Estesícoro afirmava num poema (fr. 225 PMG) que o escudo de Ulisses ostentava um golfinho, pois segundo contavam os cidadãos de Zacintos este animal salvara o pequeno Telémaco de se afogar. Cf. Bowra (1963) 131-133, Campbell (1991) 157 n. 2, Van der Stockt (2005) 18-19.

${ }^{33}$ Mosaico de Aríon da Villa Romana del Casale de Piazza Armerina, Sićlia, séc. IV d.C. Vide Pe. Carmelo Capizzi S.J. et F. Galati (s/d), Piazza Armerina. Les mosäques et Morgantina. Bologna, Éditions Italcards, 50-51; http://www.villadelcasale.it/ (acedido em 6/07/2010). 


\section{A recepçáo da lenda de Aríon na arte} ocidental: alguns exemplos

$\mathrm{Na}$ cultura do Ocidente, a lenda do citaredo grego tornou-se muito popular sobretudo a partir do Renascimento, provavelmente desde que surgiram as primeiras ediçóes impressas das Histórias de Heródoto e do Banquete dos Sete Sábios de Plutarco. No que respeita a este autor, a editio princeps das Vidas Paralelas surge em Florença, em 1517, mas logo foi suplantada pela edição de Aldo Manúcio, saída em Veneza em 1519. Da editio princeps dos Moralia, impressa pelo mesmo em Veneza, em 1509, ocupou-se Demetrios Ducas (com a colaboração de Erasmo de Roterdão e Andreas Torresanus). Em 1572, Henri Etienne (Stephanus) publica em Paris a primeira ediçáo completa das obras de Plutarco. No entanto, para a sua divulgação foram fundamentais as traduçóes latinas e as versôes em língua vernácula. No que respeita às primeiras, muito numerosas no século $\mathrm{XVI}$, merecem destaque as realizadas por Xylander (Vitae, 1561; Moralia, 1570) e Cruserius (Vitae, 1564; Moralia, 1573). Quanto às segundas, a mais influente, designadamente no domínio das artes, foi a tradução francesa de Jacques Amyot (Vitae, 1559; Moralia, 1572). Baseia-se nesta versão a tradução inglesa das Vidas Paralelas, por Thomas North, publicada em 1579, que se tornou na principal fonte das peças de temática romana de Shakespeare. A primeira tradução inglesa completa dos Moralia foi realizada por Philemon Holland a partir do original 
grego, ainda que com influência de Amyot, e impressa em $1603^{34}$.

O tema do poeta Aríon salvo por um golfinho não foi tão influente na arte ocidental como os mitos sobre divindades e heróis da Antiguidade clássica. Mesmo assim, o catálogo organizado por Jane D. Reid em 1993 menciona cinquenta e oito obras, sendo a mais antiga a decoração a fresco dos tectos da Camera degli Sposi ou Camera Picta do Palácio Ducal de Mântua, realizada entre c. 1465 e 1474 por Andrea Mantegna (14311506), e a mais recente o livro The Dolphin, do poeta americano Robert Lowell (1917-1977), publicado em Nova Iorque em 1973 e vencedor do prémio Pulitzer.

Ainda que não seja exaustiva, esta compilação permite verificar que ao longo de seiscentos anos, a lenda de Aríon foi apreciada por pintores, escultores, compositores e escritores, em especial como alegoria do poder da poesia e da música sobre as forças e os seres da natureza. A gentileza dos golfinhos para com os humanos e a relação com o divino, que os elege como salvadores, bem como a atracção destes animais pela música são outros tópicos sedutores que vêm já

${ }^{34}$ Os dados aqui apresentados foram recolhidos essencialmente de Russell (1973) 143-158 e, em especial, de Pérez Jiménez (2008) 120-126, que examina em detalhe esta matéria. No que respeita às traduções realizadas nos séc. XIV e XV, vide Becchi (2010) 23-38, que regista três ediçóes do Banquete dos Sete Sábios, no período compreendido entre 1439 e 1452, pelos humanistas italianos Antonio Cassarino (1439-1447), Giovanni Aurispa (1440-1443) e Niccolò Perotti (1449-1452). 
da tradição clássica ${ }^{35}$, designadamente do Banquete dos Sete Sábios, onde Plutarco destaca, além da afeição aos homens (philanthropia) e à música (philomousia), o gosto dos golfinhos pelas acrobacias e brincadeiras com crianças $(162 \mathrm{~F}-163 \mathrm{~A})^{36}$.

Das obras referenciadas no catálogo de Jane D. Reid merece destaque um desenho realizado em 1514 por Albrecht Dürer (1471-1528), traçado com pluma e colorido com aguarela, que representa um Aríon jovem, nu, sobre o dorso de um enorme golfinho de aspecto monstruoso e pouco realista ${ }^{37}$. Dürer não será o único artista a imaginar o salvador do poeta como um animal fantástico ou de tamanho desmedido ${ }^{38}$. Já a nudez de Aríon, que confere à figura traços míticos, é sobretudo

35 Outras lendas antigas sobre a philanthropia dos golfinhos, particularmente em relação a crianças, foram transmitidas por vários autores gregos e latinos. Vide e.g. Plínio, o Antigo, Naturalis Historia 9.20-33 (em 9.28 detém-se em Aríon); Plínio, o Jovem, Epistula 9.33 (retoma a história mencionada pelo tio em $\mathrm{NH}$ 9.26, vide Stevens 2009); Aulo Gélio, além do relato de Heródoto sobre Aríon, recorda nas Noites áticas (6.8) uma outra "história extraordinária sobre o amor de um golfinho por um menino"; Cláudio Eliano, NA 2.6, 6.15, 8.3, 8.11; Ateneu 13.606c-f. Vide Higham (1960), Bowra (1963) 131 sqq., especialmente.

${ }^{36}$ Para o exame das referências a animais e, em especial, ao golfinho no tratado de Plutarco, vide Newmeyer (2009).

${ }^{37} \mathrm{O}$ desenho de Albrecht Dürer, que inclui a epígrafe Pisce super curvo vectus cantabat Arion («sobre o curvo peixe transportado cantava Aríon»), integra actualmente a colecção Graphische Sammlung Albertina (Viena de Áustria), segundo Impelluso (2004) 350. Os traços fantasiosos do golfinho contrastam com o realismo dos estudos da natureza que integram a mesma colecção e aproximam-se muito mais do desenho a pena que realizou em 1515 do Rinoceronte, hoje no Museu Britânico. Cf. Wolf (2006) 40, 55.

${ }^{38}$ Cf. e.g. a gravura Three Men of War in a Tempest Sailing to the Right, with Arion (1565), de Pieter Bruegel, o Velho (1525-1569). 
uma inovação relativamente à tradição literária mais influente, na qual, como vimos, as vestes de gala do citaredo têm grande importância.

Não sendo possível fazer aqui um estudo detalhado da recepção desta lenda grega, propomos agora uma breve análise de algumas obras que não figuram no catálogo acima referido, no sentido de mostrarmos a diversidade de tratamentos artísticos que ela inspirou.

Uma das evocaçóes mais antigas do citaredo de Lesbos encontra-se na tapeçaria $A$ ilha da Fortuna, da série As Honras, que foi realizada em lá, seda, prata e ouro, entre 1520 e 1525, na oficina de Pieter van Aelst, em Bruxelas, e pertence hoje ao Património Nacional de Espanha ${ }^{39}$. A Fortuna surge retratada sob a forma de uma mulher coroada, de olhos vendados, a montar um cavalo e ocupa o centro da peça, acima da roda da sorte que divide a tapeçaria em duas partes. À direita da Fortuna encontram-se os favorecidos, a quem distribui rosas, enquanto os miseráveis, à sua esquerda, são fustigados com pedras e com os raios de Hefestos. Entre estes podemos ver Átamas, Hécuba, Seleuco, a Paupertas (Pobreza), Cleópatra e Ápio Cláudio. Do lado oposto, protegidos por Febo Apolo, estão, entre outras figuras mitológicas e históricas, Polícrates, tirano de Samos,

${ }^{39}$ Segóvia, Palacio Real de La Granja de San Ildefonso, Museo de Tapices (série 8). O mercador e tapeceiro Pieter van Aelst já havia realizado, entre 1516 e 1519, a partir de cartóes de Rafael, a célebre armação Actos dos Apóstolos destinada à Capela Sistina, que lhe trouxe grande fama. A autoria dos cartóes de Los Honores é desconhecida, embora se suspeite que Bernard van Orley e Jan Gossart tenham colaborado na sua elaboração. Cf. Delmarcel (1999) 75, 78, 148; Campbell (2002) 184-185, 289. 
Rómulo e Remo, crianças, a serem amamentados pela loba, Dânae com o filho ao colo, Europa e o touro, Andrómeda prisioneira e Perseu (adulto) prestes a libertá-la. Aríon integra o grupo dos afortunados e surge no canto inferior a executar uma harpa sobre o dorso de um golfinho, envergando vestes sumptuosas, como é descrito nas fontes antigas. A tapeçaria mostra a ilha da Fortuna, à qual muitos tentam chegar atravessando o mar, mas nem todos com sucesso. Constitui a primeira de nove peças que representam alegoricamente as qualidades que um soberano deve possuir e os vícios que deve evitar (Fortuna, Prudentia, Virtus, Fides, Honor, Fama, Justitia, Nobilitas e Infamia, segundo a ordem proposta por G. Delmarcel, cf. Campbell 2002, 175), se quiser obter Glória, Nobreza e Honra, sem cair na Infâmia. As nove tapeçarias de Los Honores formam uma das mais importantes colecçôes flamengas e supóe-se que terá sido encomendada pela corte de Habsburgo para homenagear Carlos V, eleito em 1519 Imperador do Sacro Império Romano e coroado em 23 de Outubro de $1520^{40}$.

Verdadeira ostentação de riqueza e poder para os seus proprietários, testemunho inegável do talento dos mestres tapeceiros, em especial da Flandres, da Baixa Idade Média ao período Barroco a tapeçaria constituiu umas das formas de arte mais excepcionais da cultura europeia. Rivalizava com a pintura, foi por ela

40 No que respeita à encomenda, datação, fontes literárias e filosóficas, e análise iconográfica das famosas tapeçarias, vide especialmente Delmarcel (1999) 147-154, Campbell (2002) 175-185, 288-290, com ilustrações e referências bibliográficas. 
influenciada e inspirava-se nas mesmas fontes: os textos bíblicos, os autores greco-latinos, a mitologia clássica e os episódios mais célebres da História antiga. No entanto, raramente conseguimos ter certezas sobre as fontes literárias ou iconográficas de determinada peça ou série, como é o caso de Los Honores (cf. Delmarcel 1999, 148, Campbell 2002, 184). Sabemos, porém, que algumas tapeçarias se baseiam em Plutarco e apresentamos, como anexo a este trabalho (II), uma breve nota sobre essa influência.

Alguns anos após a coroação de Carlos $\mathrm{V}$ foi impresso em 1531 na Alemanha, em Augsburgo, o Emblematum liber, do milanês Andrea Alciato (ou Alciati, 1492-1550), que viria a ter grande repercussão na Europa ocidental e contribuiu para a difusão de muitos temas greco-latinos, designadamente no que respeita à interpretação alegórica e moralizadora deste legado clássico (cf. Hallyn 1993, 315-319). Publicado originalmente em latim, o livro de Alciato conheceu durante a vida do autor várias ediçóes revistas (o número total de emblemas fixou-se em 212), foi muito traduzido e imitado, tendo exercido uma influência notável no domínio das artes, em especial nos séculos XVI e XVII. Na edição de 1536, saída em Paris, o título mudou para Emblematum libellus e a obra vulgarizou-se como Emblemata. O termo emblema recupera da noção greco-latina a alusão a um trabalho artístico e, mais do que um simples poema, distingue-se pela combinação de três elementos: uma sentença ou um provérbio (mote, lema ou inscriptio), uma gravura, alusiva ao tema 
ou objecto (pictura, icon, symbolon) e um epigrama ou texto em prosa, de carácter explicativo (subscriptio) ${ }^{41}$.

A lenda de Aríon salvo por um golfinho figura no livro de Alciato desde as primeiras impressôes (emblema $\mathrm{XC)}$ com o mote In avaros, vel quibus melior conditio ab extraneis offertur ("Contra os gananciosos ou para os que recebem melhor trato de estranhos»), que se manteve nas ediçóes posteriores, e com o seguinte epigrama ${ }^{42}$ :

Delphini insidens vada caerula sulcat Arion,

Hocque aures mulcet, fraenat et ora sono.

Quam sit avari hominis, non tam mens dira ferarum est:

Quique viris rapimur, piscibus eripimur.

No dorso do delfim Aríon sulca as cerúleas águas,

encanta os ouvidos da criatura e refreia a sua boca com este [som.

Não é táo selvagem a mente das feras como é a de homens [gananciosos. Quando homens nos raptam, peixes nos resgatam.

A gravura, que foi variando ligeiramente de edição para edição, retrata dois momentos do salvamento: em primeiro plano, no qual surge em destaque o golfinho com a boca muito aberta, de aspecto

${ }^{41}$ Amaral Jr. (2005) 7-11; B. F. Scholz (2007), in M. Landfester (ed.), Brill's New Pauly, Encyclopaedia of the Ancient World, Classical Tradition. Vol. II. Leiden: Brill, 165-169, s.v. Emblems.

${ }^{42}$ Vide o site Alciato's Book of Emblems. The Memorial Web Edition in Latin and English, que reproduz o texto latino e as imagens da edição de 1621 (Pádua, P. P. Tozzi, 152a ed.): http:// www.mun.ca/alciato/090.html (acedido em 15/07/2010). 
ameaçador e formas monstruosas, os marinheiros de uma embarcação (do tempo de Alciato) lançam ao mar uma pessoa; em segundo plano, entre a linha do navio e a do horizonte, vê-se Aríon, a salvo, sobre o dorso do golfinho a executar a sua harpa. A representação fantasiosa do cetáceo (identificado como "peixe»), o formato do instrumento musical e a concepção geral da imagem faz lembrar o desenho que Albrecht Dürer realizou em 1514 e supomos que possa ter sido por ele influenciado. É legítimo pensar que o livro de Alciato e as sucessivas traduçóes tenham também contribuído para a popularidade da história de Aríon. Na tradução francesa dos Emblemata publicada em Paris em 1584 (ed. Jean Richer, trad. Claude Mignault), a subscriptio inclui, além do epigrama acima citado, um texto em prosa com a observaçáo de que o emblema se inspira num epigrama de Bianor (Antologia Palatina 9.308) ${ }^{43}$. Em três dísticos elegíacos o poeta grego recorda os dados principais do mito e encerra com uma pergunta retórica: «Teria, então, o mar peixes mais justos do que os homens?». É provável, porém, que Alciato se tenha baseado noutras fontes literárias e iconográficas ${ }^{44}$.

Voltamos ao domínio das artes decorativas para destacar uma obra que merece certamente a nossa atenção e foi estudada com grande detalhe por Victor Jabouille em 1985: uma colcha bordada do

${ }^{43}$ Vide a informação disponível no site French Emblems at Glasgow: http://www.emblems.arts.gla.ac.uk/french/emblem. php?id=FALc089 (acedido em 15/07/2010).

44 Para uma análise mais detalhada desta questão, vide Pérez Jiménez (2005). 
século XVII, de fabrico indo-português, que integra as colecçóes do Museu Nacional de Arte Antiga (inv. 2237) e é considerada um dos melhores exemplares deste tipo de trabalho ${ }^{45}$. Confeccionada em algodáo branco bordado a seda selvagem (tussah, menos suave e brilhante do que a seda natural), em ponto de cadeia, de margarida e nó, esta peça tinha a função de decorar uma cama e, à semelhança de outras colchas do mesmo género, combina temas bíblicos com mitos clássicos (neste caso a história de Aríon e de Hércules, em especial), com a mitologia hindu e cenas da vida quotidiana (designadamente de caça). Trata-se, portanto, de um artefacto que é fruto da síntese de dois legados - o judaico-cristáo e o greco-romano - e do contacto de duas culturas: a europeia/ocidental e a indiana/oriental.

A história de Aríon é contada em dezasseis quadros dispostos à volta do painel central rectangular, que representa a Justiça de Salomáo - um episódio bíblico recorrente nas colchas indo-portuguesas ${ }^{46}-$, e pode ser resumida do seguinte modo:

(1) Os rios, os seres da natureza e os homens imobilizavam-se para escutar o canto sedutor de Aríon (1-7);

(2) Durante a viagem de regresso à pátria, é

45 Vide http://www.matriznet.imc-ip.pt/ipm/MWBINT/ MWBINT00.asp (acedido em 15/07/2010).

${ }^{46}$ Cf. e.g. a colcha indo-portuguesa dos sécs. XVI-XVII, tecida em linho e bordada a fio de seda amarelo, do Museu Nacional Machado de Castro (inv. 6984). Vide F. Alves e P. Ferrão (2005), "Arte dos tecidos e dos bordados», in A. Alarcáo (coord.), Museu Nacional Machado de Castro. Roteiro. Lisboa, IPM, 140, 151. 
ameaçado de morte pelo timoneiro e, após uma última actuação, lança-se ao mar (8-11);

(3) É salvo por um golfinho, que suscita a piedade dos deuses, pelo que Júpiter (identificado pela águia) o recompensa, colocando-o no céu entre as estrelas.

As cenas, dispostas em faixas, sucedem-se segundo um esquema que se aproxima da banda desenhada. A decoração destas colchas é, portanto, narrativa e as figuras surgem habitualmente caracterizadas à moda portuguesa do início do século XVII. Aríon aparece assim a executar um instrumento musical que pode ser um alaúde, mas que náo tem nada a ver com a cítara antiga nem com a harpa que aparece no desenho de Albrech Dürer ou na tapeçaria $A$ ilha da Fortuna. Já o golfinho é uma criatura híbrida, com focinho de mamífero e grandes escamas no resto do corpo. À semelhança das obras comentadas anteriormente, as suas formas são completamente fantásticas. Uma análise mais cuidada das dezasseis cenas confirma que esta história de Aríon não se baseia em Heródoto nem em Plutarco, mas segue de muito perto a versão dos Fastos de Ovídio (2.79-118). De facto, se a $14^{\mathrm{a}}$ cena - na qual vemos Aríon a executar o instrumento musical sobre o dorso do golfinho - ilustra bem os vv. 115-116 acima citados, as duas últimas cenas não podiam estar mais próximas destas palavras finais (vv. 117-118):

di pia facta uident: astris delphina recepit Iuppiter et stellas iussit habere nouem. 
Os deuses vêem os feitos piedosos: entre os astros o golfinho [recebeu Júpiter e quis que tivesse nove estrelas.

O golfinho é colocado no céu e recebe como séquito as estrelas que constituem a constelação Delphinus (Delfim, Golfinho) do hemisfério norte, uma das que foi identificada na Antiguidade.

Segundo Teresa P. Pereira, uma colcha muito semelhante, existente no Museo Nazionale del Palazzo di Venezia, em Roma, cuja decoração se baseia igualmente nas temáticas clássicas principais da peça do Museu Nacional de Arte Antiga, inclui legendas em português e numa lê-se «Fábula jocosa conta Ovídio» (Pereira e Alarcão 1988, 9-11). Como é sabido, o poeta latino foi um dos principais transmissores dos temas clássicos e, além da sua popularidade, quer na Idade Média quer no Renascimento, as ediçóes das suas obras eram também as mais ilustradas, tendo sido fonte de inspiração de muitos escritores e artistas ${ }^{47}$. É plausível, por isso, que os modelos visuais das colchas indo-portuguesas remontem às ilustraçóes das suas obras, como tem sido sugerido (Jabouille 1985, 59; Pereira 1988, 11). O destaque dado à lenda de Aríon e à saga dos trabalhos de Hércules, além da presença menos relevante de

${ }^{47}$ Vide e.g. A. Monteverdi (1959), «Ovidio nel Medio Evo», in F. Arnaldi et alii, Studi Ovidiani. Roma, Istituto di Studi Romani Editore, 63-78; N. Lascu (1959), "La fortuna di Ovidio dal Rinascimento ai tempi nostri», ibidem, 79-112; E. K. Rand (1963), Ovid and his Influence. New York, Cooper Square Publishers, 108-156; S. Viarre (1976), Ovide. Essai de lecture poétique. Paris, Les Belles Lettres, 117-137. 
muitas outras figuras da mitologia greco-latina, não é exclusivo destas duas peças, já que são temáticas recorrentes nas colchas bordadas indo-portuguesas. Ao analisar as razóes da popularidade da história de Aríon nas suas decoraçóes e na época em que foram fabricadas (a dos Descobrimentos), V. Jabouille (1985, 54-55) sublinhou os seguintes aspectos: em primeiro lugar, o enaltecimento da poesia (e da arte em geral), que justifica o salvamento do poeta por intermédio do golfinho, ser ligado a Apolo, o protector das artes; por outro lado, a familiaridade da temática náutica, em especial os perigos das viagens por mar, bem como a própria caracterização de Aríon, o homem que procura o seu sustento longe da pátria, enriquece graças ao seu trabalho e talento, atravessa dificuldades, mas é salvo, porque os deuses o protegem; finalmente, pode também ter tido influência a simbologia associada ao golfinho como representante do Cristo Salvador.

A colcha bordada indo-portuguesa é um artefacto singular, ainda pouco estudado, ao que parece, e não deixa de ser extraordinário que tenha valorizado uma temática que na Antiguidade teve tão poucas representaçôes iconográficas. As «notas interpretativas» que V. Jabouille nos deixou sobre esta peça do Museu Nacional de Arte Antiga são um excelente ponto de partida para o seu conhecimento.

Ao contrário do que habitualmente acontece com os temas clássicos, a lenda de Aríon não tem sido fértil no domínio da pintura, mas verifica-se uma grande 
variedade de tratamentos ${ }^{48}$. Chamamos brevemente a atenção para um óleo sobre madeira de Gustave Moreau (1826-1898). A poesia foi uma das temáticas mais importantes da carreira deste artista francês táo influenciado pelos temas greco-romanos e precursor da estética simbolista ${ }^{49}$. A obra Arion, porém, pintada em 1891 e hoje conservada no Museu do Petit Palais de Paris, é das menos conhecidas ${ }^{50}$. No pensamento de Moreau, a arte não devia ser uma ilustração pura dos textos, mas somente abrir o caminho à imaginação e à seduçáo dos sentidos. Neste quadro, a figura colorida e exótica de Aríon levado sobre as águas por um majestoso golfinho destaca-se de uma paisagem sombria que lembra cenários renascentistas. $\mathrm{O}$ poeta salvo in extremis, graças ao seu dom, não cessa de cantar mesmo durante o salvamento. Os trajes ornamentados e a cítara na mão evocam uma imagem que parece

${ }^{48}$ Um dos mais invulgares é uma obra de Francesco Bianchi Ferrari (c. 1460?-1510), que retratou Aríon sobre um golfinho como um menino nu: Arion riding on a Dolphin (c. 1509-1510). University of Oxford, Ashmolean Museum (A733). Vide http:// www.ashmolean.info/ash/objects/paintings/WA1947.243.php. Mais conhecido éo óleo sobre tela de François Boucher (1703-1770): Arion on the Dolphin (1748). Princeton University Art Museum (y1980-2). Vide http://artmuseum.princeton.edu/art/collections/ european/search/. William-Adolphe Bouguereau (1825-1905) alterou os dados do mito ao compor Arion sur un cheval marin (1855). The Cleveland Museum of Art (1980.238). Vide http:// www.clevelandart.org/ (sites acedidos em 15/07/2010).

${ }^{49}$ Veja-se o nosso estudo (2009), «A herança clássica na pintura de Gustave Moreau. O tema de Safo», Boletim de Estudos Clássicos 51, 111-116, com referências bibliográficas.

${ }^{50}$ Petit Palais, Musée des Beaux-Arts de la Ville de Paris (inv. PPP00754). Vide http://www.petitpalais.paris.fr/fr/collections/ arion (acedido em 15/07/2010). 
sair directamente do texto de Plutarco, mas a pintura transmite a impressão de que esta personagem é mais lendária do que real, mais divina do que humana, como se não fosse mais do que uma metáfora da inspiração poética. A magnificência da figura de Aríon, na qual sobressaem os tons avermelhados da indumentária e a ornamentaçáo do instrumento musical, aproxima-se grandemente das composiçóes sobre Safo, que o pintor tratou sobretudo entre 1867 e $1884^{51}$. É possível que a semelhança não seja casual, porque um dos temas que mais seduziu Gustave Moreau foi precisamente o suicídio da poetisa de Lesbos, que parece ser sobretudo uma metáfora da perda da inspiração poética. Aríon, porém, é resgatado pelo animal divino, graças ao seu canto e graças ao qual continuará a viver.

O catálogo de Jane D. Reid termina em 1973, mas desde essa data outras obras retomaram a história do salvamento de Aríon. Uma das mais recentes de que temos conhecimento é a ópera Arion \& the Dolphin, encomendada pela English National Opera e estreada em Junho de 1994. Com música composta por Alec Roth e libreto do escritor inglês de origem indiana Vikram Seth, desenvolve as linhas principais da lenda clássica em nove cenas, desde a partida de Aríon da corte de Periandro até ao seu regresso a Corinto. Esta versão dá grande relevo à philanthropia e philomousia dos golfinhos, para daí retirar uma mensagem de

${ }^{51}$ Cf. e.g. a aguarela Sapho sur le rocher (1871-1872). Londres, Victoria and Albert Museum (P.11-1934). Vide http://collections. vam.ac.uk/item/O16435/watercolour-sappho/ (acedido em 15/07/2010). 
sentido universal: o valor da amizade. O título deriva em particular da VIa Cena, quando o citaredo é resgatado por um golfinho que consegue falar e cantar. Aríon, que até então era um jovem aclamado pelo seu talento, mas triste e solitário, recupera, graças à amizade e simpatia deste ser táo especial, a vontade de viver. A evocação das fontes clássicas, designadamente de Plutarco, é especialmente notória nesta VIa Cena, da qual merece a pena citar um excerto (Seth 1994, 44-46):

\section{DolPHIN:}

Icadius, Iapys' Cretan brother,

Shipwrecked, was guided by

A dolphin to Delphi;

And from that dolphin Delphi got its name:

Apollo and the dolphin were the same.

Or when Enalus saw his lover slung

Into the sea to calm the waves he flung

Himself into the waves that they might be

United constantly

A dolphin saved him, and its mate his mate

From their too-fluid fate. (...)

Arion:

What joyful lives you dolphins lead

Both when you mate and when you feed.

Compare it to my own condition -

A poor, unhappy, flipperless musician.

DoLPHIN:

Oh, no - 
You interest us, we interest you.

And we can tell who's who.

And we like music too.

We have our ancient musical traditions.

That's why we are susceptible to musicians.

Perhaps we should sing together after supper.

You take the lower part, I'll take the upper. (...)

Arion:

The days pass one by one.

I feel my life has only just begin -

And, for the first time, I am having fun!

Arion and Dolphin:

In air and water both, our voices part and blend, And I/you, who never sought a friend Have found one in the end.

Do libreto de Vikram Seth fez-se uma adaptação para crianças com ilustraçóes de Jane Ray (London, Orion, 1994). A história da amizade entre um músico e um golfinho desperta naturalmente a atenção dos mais novos, pelo que a aventura de Aríon figura também entre os temas favoritos da literatura infantil.

Em conclusão, esta história, que contém a dose necessária de maravilhoso e de verosimilhança, continua a inspirar os escritores e artistas do nosso tempo, provando a vitalidade dos temas greco-romanos. A imagem majestosa do poeta de Lesbos, o poder encantatório da sua arte, a philanthropia e philomousia dos golfinhos, o salvamento concebido como manifestaçáo 
da providência são alguns dos elementos que têm sido privilegiados e que já eram fundamentais na versão de Heródoto e muito especialmente na de Plutarco. 


\section{BibLIOGRAFia}

\section{EDIÇÓES, COMENTÁRIOS E TRADUÇÓES}

Campbell, D. A. (1991), Greek Lyric III. Cambridge, Mass., Harvard University Press.

Campbell, D. A. (1993), Greek Lyric V. Cambridge, Mass., Harvard University Press.

Defradas, J., Hani, J., Klaerr, R. (1985), Plutarque. Oeuvres Morales. Tome II. Paris, Les Belles Lettres.

Evelyn-White, H. G. (1936), Hesiod, Homeric Hymns, Epic Cycle, Homerica. Cambridge, Mass., Harvard University Press.

Ferreira, J. R., Silva, M. F. (1994), Heródoto. Histórias: livro $1^{\circ}$. Introdução geral de $\mathrm{M}$. H. Rocha Pereira. Introdução ao Livro I, versão do grego e notas de J. R. Ferreira (1.1-94) e de M. F. Silva (1.95-216). Lisboa, Ediçóes 70.

Ferreira, J. R. (2006), Espelho da Alma. O vinho na poesia grega. Antologia de textos. Anadia, Museu do Vinho.

Frazer, J. G. (1989, 2a ed.), Ovid. Fasti. Revised ed. by G. P. Goold. Cambridge, Mass., Harvard University Press.

Hude, C. (1927, 3a ed.), Herodoti Historiae. 2 vols. Oxford, Clarendon Press. 
Leâo, D. F. (2008), Plutarco. Obras Morais. O Banquete dos Sete Sábios. Tradução do grego, introdução e notas. Coimbra, CECH.

Maenler, H. (1989), Pindari Carmina cum Fragmentis. Pars II: Fragmenta, Indices. Leipzig, Teubner. [Maehler]

Page, D. L. (1962), Poetae Melici Graeci. Oxford, Clarendon Press. [PMG]

- (1981), Further Greek Epigrams. Cambridge, University Press.

Paton, W. R. (1974), Plutarchi Moralia I. Leipzig, Teubner.

Race, W. H. (1997), Pindar II. Cambridge, Mass., Harvard University Press.

Seth, V. (1994), Arion \& the Dolphin. A libretto. London, Phoenix House.

West, M. L. (2003), Homeric Hymns. Homeric Apocrypha. Lives of Homer. Cambridge, Mass., Harvard University Press.

\section{Estudos}

Amaral JR., R. (2005), Emblemática Lusitana e os Emblemas de Vasco Mousinho de Castelbranco. Introdução, transcrição e arranjo gráfico. Lisboa, Centro de História da Universidade de Lisboa.

Aulotte, R. (1965), Amyot et Plutarque: la tradition des Moralia au XVIe siècle. Genève, Droz. 
Becchi, F. (2010), «El redescubrimiento de Plutarco en la edad del Humanismo», in A. Pérez Jiménez (ed.), Plutarco Renovado. Importancia de las Traducciones Modernas de Vidas y Moralia. Málaga, Grupo Editorial 33, 23-38.

Boardman, J. (1974), Athenian Black Figure Vases. A Handbook. London, Thames \& Hudson.

— (1975), Athenian Red Figure Vases. The Archaic Period. London, Thames \& Hudson.

— (1990, 4a ed.), The Greeks Overseas. Their Early Colonies and Trade. London, Thames \& Hudson.

— (1995), Greek Sculpture. The Late Classical Period and Sculpture in Colonies and Overseas. A Handbook. London, Thames \& Hudson.

- (2001), The History of Greek Vases. Potters, Painters and Pictures. London, Thames \& Hudson.

Bowra, C. M. (1963), «Arion and the Dolphin», $M H$ 20.3, 121-134 (= On Greek Margins, Oxford, Clarendon Press, 1970, 164-181).

Burkert, W. (1983), "The Return of the Dolphin», in Homo Necans. The Anthropology of Ancient Greek Sacrificial Ritual and Myth. Berkeley, University of California Press, 196-204.

CaHn, H. A. (1984), in Lexicon Iconographicum Mythologiae Classicae (LIMC). München, Artemis, II.1: 602-603, II.2: 434-435 (s.v. Arion). 
Campbell, T. P. (2002), Tapestry in the Renaissance. Art and Magnificence. New York, The Metropolitan Museum of Art.

Delmarcel, G. (1999), La tapisserie flamande $d u X V^{E}$ au XVIII siècle. Paris, Imprimerie Nationale.

Ferreira, L. N. (2005), Mobilidade poética na Grécia antiga. Uma leitura da obra de Simónides. Coimbra, Faculdade de Letras da Universidade de Coimbra.

- (2008), «O canto de Aríon de Metimna (fr. adesp. 939 PMG)», Boletim de Estudos Clássicos 49, 21-25.

García Arranz, J. J. (1996), «La recepción de los escritos animalísticos de Plutarco en los libros de emblemas europeos durante los siglos XVI y XVII», in J. A. Fernández Delgado \& F. Pordomingo Pardo (eds.), Estudios sobre Plutarco: aspectos formales. Madrid, Ediciones Clásicas, 487-500.

Gostoli, A. (1993), «Il nomos citarodico nella cultura greca arcaica», in R. Pretagostini (ed.), Tradizione e innovazione nella cultura greca da Omero all'Età Ellenistica. Vol. I. Roma, Gruppo Editoriale Internazionale, 167-178.

Gray, V. (2001), «Herodotus' Literary and Historical Method: Arion's Story (1.23-24)», AJP 122, 11-28. 
Hallyn, F. (1993), "Mythe et embleme», in L. R. S. Tarugi (ed.), Il mito nel Rinascimento. Milano, Nuovi Orizzonti, 314-325.

Higham, T. F. (1960), «Nature Note: Dolphin-riders», $G \nLeftarrow R 7,82-86$.

Hooker, J. T. (1989), «Arion and the Dolphin», $G \& R$ $36.2,141-146$.

Ieranò, G. (1992), «Arione e Corinto», QUCC 41.2, $39-52$.

- (1997), Il ditirambo di Dioniso. Le testimonianze antiche. Pisa-Roma, Istituti Editoriali e Poligrafici Internazionali.

Impelluso, L. (2004), Nature and Its Symbols. Los Angeles, The J. Paul Getty Museum.

JABouille, V. (1985), «Temática clássica na decoração de uma colcha indo-portuguesa do século XVII», Revista da Faculdade de Letras da Universidade de Lisboa 3, 47-62.

Karouzou, S. (1992), Musée National. Guide Illustré du Musée. Atenas, Ekdotike Athenon S.A.

Lissarague, F. (2000), «Aesop, Between Man and Beast: Ancient Portraits and Illustrations", in B. Cohen (ed.), Not the Classical Ideal. Athens and the Construction of the Other in Greek Art. Leiden, Brill, 132-149. 
Mathieu, P.-L. (1994), Gustave Moreau. Paris, Flammarion.

Mendonça, M. J. (1983), Inventário de tapeçarias existentes em museus e palácios nacionais. Lisboa, Instituto Português do Património Cultural.

Moore, M. B. (1987), «The Amasis Painter and Exekias: Approaches to Narrative», in Papers on the Amasis Painter and his World. Malibu, The J. Paul Getty Museum, 153-167.

Newmeyer, S. T. (2009), "Animal Philanthropia in the Convivium Septem Sapientium", in J. R. Ferreira, D. Leão, M. Tröster \& P.

B. Dias (eds.), Symposion and Philanthropia in Plutarch. Coimbra, Classica Digitalia/CECH, 497-504.

Pereira, T. P., Alarcão, T. (1988), Fábulas bordadas. Uma colcha indo-portuguesa do século XVII. Lisboa, Museu Nacional de Arte Antiga.

Pérez Jiménez, A. (1990), «Plutarco y el Humanismo Español del Renacimiento», in A. Pérez Jiménez \& G. del Cerro Calderón (eds.), Estudios sobre Plutarco: obra y tradición. Málaga, Sociedad Española de Plutarquistas, 229-247.

(2002), «Orientaciones y aproximación bibliográfica al proyecto 'La recepción de Plutarco desde la Antigüedad hasta el siglo XVII'», in Plutarchus Redivivus. Memorandum 
del II Encuentro de la Red Temática de Plutarco (Málaga, 14-15 de junio de 2001) y Propuesta de Proyectos aprobados. Málaga, Universidad de Málaga, 27-71.

_ (2005), «Plutarco en Alciato, I», Silva 4, 235-266.

- (2008, $1^{\mathrm{a}}$ ed. 1985), «4. Fortuna de Plutarco», in Vidas Paralelas $I$. Introducción general, traducción y notas. Madrid, Editorial Gredos, 105-131.

— A. ed. (2010), Plutarco Renovado. Importancia de las Traducciones Modernas de Vidas y Moralia. Málaga, Grupo Editorial 33.

Preziosi, D., Нiтchсоск, L. A. (1999), Aegean Art and Architecture. Oxford, University Press.

Privitera, G. A. (1988), «Il ditirambo come spettacolo musicale. Il ruolo di Archiloco e di Arione», in B. Gentili e R. Pretagostini (eds.), La Musica in Grecia. Roma-Bari, Laterza, 123-131.

Reid, J. D. (1993), The Oxford Guide to Classical Mythology in the Arts, 1300-1990s. Vol. I. New York-London, Oxford University Press, 214215 (s.v. Arion).

Richter, G. M. A. (1984, 2a ed.), The Portraits of the Greeks. Abridged and revised by R.R.R. Smyth. Oxford, Phaidon. 
Robertson, M. (1978), La peinture grecque. Trad. O. Sirén. Genève, Albert Skira

Roblot-Delondre, L. (1917-1919), «Les sujets antiques dans la tapisserie», Revue archéologique 5, 296-309; 7, 129-150; 9, 48-63; 10, 294-332.

Rocha Pereira, M. H. (2009), Vasos gregos: mensagem de arte e cultura. Orgs. M. F. S. Patrocínio e C. Teixeira. Évora, CHAIA.

Russell, D. A. (1973), Plutarch. London, Duckworth.

Schamp, J. (1976), «Sous le signe d'Arion», Ant.Class 45, 95-120.

Soares, C. I. L. (2003), A morte em Heródoto. Valores universais e particularismos étnicos. Lisboa, FCG/ FCT.

Stevens, B. (2009), «Pliny and the Dolphin - or a Story about Storytelling», Arethusa 42, 161-179.

VAn Der Stockt, L. (2005), «Plutarch and Dolphins: Love Is All You Need», in J. Boulogne (ed.), Les Grecs del'Antiquité et les animaux: le cas remarquable de Plutarque. Lille, Editions du Conseil Scientifique de l'Université Charles-de-Gaulle Lille 3, 13-21.

Wolf, N. (2006), Albrecht Dürer (1471-1528). O génio do Renascimento alemáo. Trad. port. M. Neto. Munique, Taschen. 
Woodford, S. (1986), An Introduction to Greek Art. London, Duckworth.

Zimmermann, B. (1992), Dithyrambos. Geschichte einer Gattung. Göttingen, Vandenhoeck \& Ruprecht. 


\section{Anexo I - A aventura de Aríon salvo por UM GOLFINHO}

\section{FONTES LITERÁRIAS PRINCIPAIS}

\section{Heródoto, Histórias 1.23-24. Traduçáo de José Ribeiro Ferreira (1994, 68-70)}

23.1. Periandro, o que revelou a Trasibulo o oráculo, era filho de Cípselo. Periandro tornou-se tirano de Corinto e, durante a sua vida, - dizem os Coríntios e confirmam-nos os Lésbios - foi testemunha de um extraordinário prodígio: Aríon de Metimna levado ao Ténaro no dorso de um golfinho, ele que era um citaredo náo inferior a qualquer outro da sua época, o primeiro dos homens, de que temos conhecimento, a compor ditirambos, a dar-lhes esse nome e a fazê-los executar em Corinto.

24.1. Este Aríon, que viveu a maior parte do tempo junto de Periandro, contam eles, foi tomado do desejo de navegar para a Itália e para a Sicília e, depois de ganhar muito dinheiro, quis voltar de novo a Corinto. 2 . Partiu então de Tarento e, como não confiava em mais ninguém senão nos Coríntios, contratou um barco de marinheiros Coríntios. Estes, no alto mar, maquinaram lançar Aríon pela borda, para se apoderarem das riquezas. Ao ter conhecimento disso, ele implorou-lhes piedade: entregava as riquezas, mas pedia a vida. 3 . Não conseguiu, todavia, persuadi-los; pelo contrário, os marinheiros intimaram-no ou a suicidar-se, para alcançar uma sepultura em terra, ou a atirar-se ao mar, 
de imediato. 4. Reduzido a tais apuros, Aríon pediu, visto assim terem decidido, que lhe permitissem, de pé, na coberta do barco, cantar com todo o seu traje de gala. 5. Depois de cantar, acedia em pôr fim à vida. Encantou-os a ideia de poderem ouvir o melhor cantor entre os homens e retiraram-se da popa para o centro do barco. Aríon pôs todos os seus enfeites, pegou da cítara e de pé, na coberta, executou o canto órtrio. Terminado este, lançou-se ao mar, tal como estava, com todos os enfeites. 6. E enquanto eles navegavam para Corinto, conta-se que um golfinho tomou o poeta sobre o dorso e levou-o para o Ténaro. Apeado em terra, regressou a Corinto com os adornos e, uma vez aí chegado, relatou tudo o que aconteceu. 7. Periandro, por incredulidade, mantém Aríon sob custódia, sem o deixar ir para lado nenhum, mas deu atenção aos marinheiros. Logo que estes apareceram, chamou-os e informou-se se tinham algo a dizer a respeito de Aríon. Estavam eles a dizer-lhe que estava são e salvo em Itália e se encontrava bem, quando o deixaram em Tarento, e eis que lhes aparece Aríon, como estava vestido quando se lançou ao mar. E eles, consternados e convencidos, não puderam negar mais. 8. Este relato contam-no os Coríntios e os Lésbios e de Aríon existe uma estátua de bronze no Ténaro, que representava um homem no dorso de um golfinho.

Plutarco, $O$ Banquete dos Sete Sábios 18.160e-19.162b. Tradução de Delfim Ferreira Leão (2008, 109-113)

18. Gorgo contou então que havia celebrado 
sacrifícios durante três dias, sendo que o último comportava uma vigília nocturna, danças corais e $\mathrm{F}$ jogos junto à praia. A lua brilhava sobre o mar e, embora não soprasse vento e houvesse pelo contrário grande calmaria e quietude, começou a avistar-se ao longe uma crispação que avançava em direcção ao promontório, acompanhada de escuma ligeira e de um bramido intenso devido à ondulação que produzia em volta, a ponto de todos acorrerem, maravilhados, para o lugar onde se esperava que tocasse em terra. E antes que, devido à grande velocidade, pudessem imaginar o que se avizinhava, apareceram diante dos nossos olhos golfinhos: uns em grupo e dispostos em círculo, outros que se dirigiam para a zona mais chã da praia, outros ainda que ficavam atrás, como se formassem uma escolta. Ao 161A centro, emergia à superfície do mar a massa indistinta $\mathrm{e}$ indefinida de um corpo que era transportado, até que os golfinhos se juntaram todos e acostaram em conjunto, depositando em terra um homem que respirava ainda e se mexia. Em seguida, os golfinhos retomaram a direcção do promontório, dando saltos ainda maiores, como se estivessem a brincar e a fazer acrobacias devido a uma alegria inexplicável.

- Muitos de nós - continuou Gorgo ficaram tomados de pânico e fugiram do mar a correr, mas uns quantos (entre os quais me contava eu) encheram-se de coragem e aproximaram-se o suficiente para reconhecerem o citaredo Aríon, que conseguiu pronunciar o próprio nome, além de que era facilmente B reconhecível pelas roupas. Com efeito, envergava 
ainda o traje de cerimónia que costumava usar quando cantava em concursos, fazendo-se acompanhar da cítara. Transportámo-lo em seguida até uma tenda, pois não parecia ter sofrido qualquer ferimento, embora estivesse visivelmente moído e esgotado pela velocidade e rapidez do transporte. Depois, escutámos da boca dele uma história incrível para toda a gente, menos para nós que tínhamos assistido à sua conclusão! Narrou então Aríon que havia tomado, algum tempo atrás, a decisão de sair de Itália e que a recepção de uma carta de Periandro veio acentuar ainda mais esse propósito. Assim, quando atracou no porto um navio mercantil proveniente de Corinto, subiu de imediato a bordo e fez-se ao largo. Decorridos três dias de vento favorável, Aríon teve o pressentimento de que os marinheiros projectavam tirar-lhe a vida e ficou depois a saber pelo piloto - o qual the confiou essa informação em segredo - que eles estavam decididos a pôr o plano em acção nessa mesma noite. Ora encontrando-se ele sozinho e sem possibilidade de obter auxílio, decidiu dar seguimento a uma ideia de inspiração divina: adornar-se e, estando embora vivo, endossar como vestimenta fúnebre o seu traje de cerimónia e entoar um último canto em honra da vida, agora que estava para terminá-la, mostrando com este gesto uma nobreza não menor que a dos cisnes. Ora uma vez concluídos estes preparativos, anunciou que desejava entoar um dos seus hinos a Apolo, a fim de acautelar a própria segurança, a do barco e a de todos os tripulantes. Tomou então um lugar na ponta do barco, junto à popa, principiou por modular como prelúdio 
uma invocação aos deuses marinhos e depois pôs-se a entoar o hino. Quando não havia ainda chegado a meio da ode, o sol começou a mergulhar nas águas e

D a costa do Peloponeso a aparecer no horizonte. Então, os marinheiros decidiram não esperar pela noite e avançaram com intenção de matá-lo. Ao ver os punhais desembainhados e o piloto que já cobria os olhos, ele tomou balanço e lançou-se borda fora, para o mais longe possível do barco. Antes que o corpo ficasse completamente submerso pelas águas, alguns golfinhos puseram-se a nadar debaixo dele e trouxeram-no à superfície. De início, ficou completamente confuso, ansioso e atarantado. Porém, ao constatar a facilidade com que o transportavam, ao ver os golfinhos agrupados em grande número, amigavelmente, à sua volta, assumindo à vez aquela tarefa, como se fosse obrigatório nela tomar parte e a todos dissesse respeito, e ao ter a sensação da velocidade a partir do facto de o barco

E ter ficado bem para trás, sentiu nascer dentro de si contou ele — não tanto o receio perante a morte nem propriamente um desejo de viver, mas antes o orgulho de poder salvar-se (aparecendo como um homem caro aos deuses) e desenvolver uma crença inabalável no respeitante à divindade. Por outro lado, ao contemplar o céu repleto de estrelas e a lua a elevar-se, cintilante e límpida, ao mesmo tempo que o mar se apresentava a toda a volta sem ondas, como que oferecendo um trilho aberto para lhes servir de caminho, pensou para consigo mesmo que a Justiça não possui um olho apenas, mas que com estes múltiplos olhos a divindade observa em 
todas as direcçóes o que vai sendo praticado, tanto em terra como no mar. Disse ainda que, através destas cogitaçôes, ia encontrando lenitivo para suportar a fadiga que já se abatia sobre o seu corpo. E por fim, quando lhes apareceu pela frente o promontório, íngreme e alcantilado, os golfinhos evitaram-no facilmente, descrevendo uma curva sobre a superfície das águas, e foram nadando ao longo da praia, como se estivessem a conduzir em segurança um barco até ao porto. Nessa altura, Aríon compreendeu perfeitamente que o seu resgate fora conduzido por um deus.

- Depois de Aríon haver relatado estes $162 \mathrm{~A}$ pormenores, - continuou Gorgo - perguntámos-lhe onde iria, em sua opinião, o barco atracar. Ele respondeu que seria certamente em Corinto, mas que, em todo o caso, ainda tardaria muito a chegar. Com efeito, depois de, ao fim da tarde, se haver lançado borda fora, ele achava que o teriam transportado durante não menos de cinquenta estádios; e entretanto, a calmaria teria retido o navio.

Ainda assim, Gorgo esclareceu que logo se informou acerca do nome do armador e do piloto, bem como do emblema do barco, tendo também enviado navios e soldados para montarem guarda aos locais de desembarque. Quanto a Aríon, tinha-o trazido consigo às escondidas, a fim de evitar que os culpados, ao tomarem conhecimento prévio do seu salvamento, se pusessem em fuga. $\mathrm{Na}$ verdade, tudo parecia ter acontecido segundo os desígnios da divindade: com efeito, logo à chegada a Corinto, ficara a saber que o 
barco havia sido entretanto arrestado pelos soldados, que tinham capturado igualmente os comerciantes e os marinheiros.

19. Periandro deu então instruçôes a Gorgo para que partisse de imediato e fosse meter aquelas pessoas na prisão, de maneira a ninguém ter acesso a elas e não as poder informar de que Aríon escapara são e salvo.

\section{Cláudio Eliano, Natureza dos animais $12.45=$} fr. 939 PMG. Traduçáo de Luísa de Nazaré Ferreira $(2008,23)$

Supremo deus, senhor do mar, Poséidon do tridente de ouro, que a terra sacode com vagas ondeantes, à tua volta, com suas barbatanas, os aquáteis seres dançam em círculo em lances rápidos, saltando com agilidade, criaturas de focinho chato, colo cerdoso, velozes, golfinhos amantes da música, prole marinha das divinas filhas de Nereu, os quais Anfitrite gerou: eles é que para a terra de Pélops me levaram, rumo ao cabo Ténaro, andava eu errante no mar da Sicília, acolhendo-me em seus dorsos curvos, abrindo sulcos na planura de Nereu, passagem não trilhada, quando homens pérfidos me lançaram da mareante [côncava nau para as ondas purpúreas do mar. 


\section{Anexo II - Plutarco e a arte ocidental A influência da obra de Plutarco na tapeçaria FLAMENGA}

A determinação segura das fontes literárias de uma tapeçaria ou conjunto de tapeçarias (armação, série$\left.^{1}\right)$ não é tarefa acessível, como dissemos acima, nem tão pouco o é a identificação das temáticas ou peças que possam ter sido inspiradas pela extensa obra de Plutarco. $\mathrm{Na}$ Idade Média, os mestres tapeceiros recolhiam habitualmente de manuscritos os assuntos a tratar, mas no Renascimento são os livros impressos e ilustrados com gravuras que lhes vão fornecer as principais fontes de trabalho. A história antiga fora sempre um tema favorito, mais ainda do que a mitologia clássica, com a qual era muita vezes combinada. No século XVI, porém, com a impressão dos originais e sucessivas traduçôes dos autores latinos e gregos - como Tito Lívio e Plutarco - os episódios da história antiga, em especial de Roma, e das vidas e feitos de grandes líderes políticos e militares alcançam uma popularidade extraordinária. A divulgação deste legado autêntico vai permitir ainda a valorização da organização cronológica dos assuntos de natureza histórica, um aspecto de grande importância na concepçáo das séries de tapeçarias. Nas palavras de L. Doblot-Delondre $(1917,302)$ : «Ce fut le grand titre

${ }^{1}$ A distinçáo que se faz por vezes entre «armação» (fr. tenture, conjunto de panos murais ligados entre si pelo tema) e "série» (armação reproduzida várias vezes) nem sempre é considerada pelos especialistas e os termos são também usados como sinónimos. 
de gloire des humanistes florentins d'avoir rétabli la chronologie dans l'histoire; avec eux les faits historiques reprennent leurs valeurs relatives, les héros de l'antiquité leur place réelle dans l'histoire et les délicieuses légendes de la mythologie grecque deviennent des fictions aimables qui seront la source principale de l'inspiration des artistes de la Renaissance.»

Para a redacção desta breve nota baseámo-nos, em primeiro lugar, no clássico La tapisserie flamande $d u$ $X V^{E}$ au XVIII siècle, de Guy Delmarcel, que menciona o nome de Plutarco a propósito das seguintes séries:

- História de Rómulo e Remo, fundadores de Roma, a partir de Tito Lívio e da Vida de Rómulo, de Plutarco; foi um dos temas romanos mais representados na tapeçaria flamenga do século XVI;

- César e Cleópatra; a Vida de César de Plutarco é uma das fontes;

- História grega ou Homens célebres segundo Plutarco (Hommes célèbres d'après Plutarque).

Embora esta série não seja mais importante do que as que tratam Rómulo e César, tem mais interesse para nós por se basear directamente na tradução de Jacques Amyot das Vidas Paralelas. A realização dos cartóes foi encomendada em 1711 ao pintor Victor Janssens (Bruxelas, 1658-1736), tarefa que lhe viria a trazer grande fama, pela sociedade constituída pelos irmãos Urbain e Daniel II Leyniers e Henri II Reydams, em cujas oficinas foram executadas as peças. Cada tapeçaria era dedicada a uma personalidade da Antiguidade e destinavam-se a um círculo de clientes militares. As obras, das quais se 
preservam várias ediçôes, todas realizadas nos mesmos ateliês de Bruxelas, devem certamente ter agradado, visto que o número de assuntos aumentou de oito, em 1715, para onze, em 1734. Nas pp. 328-329 do livro de Guy Delmarcel é reproduzida a tapeçaria $O$ sacrifício de Aristides $(370 \times 420 \mathrm{~cm}$ ), que representa o político ateniense a oferecer um sacrifício junto do monumento funerário de um general ${ }^{2}$.

Destas breves linhas se conclui que é mais fácil identificar as peças inspiradas nas Vidas Paralelas do que nos Moralia, que devem ter existido seguramente. Por conseguinte, é de supor que outras séries, nomeadamente as que integram as colecçóes dos museus nacionais, se baseiem, pelo menos em parte, em Plutarco.

No que respeita aos temas acima referidos, registese que o Palácio Nacional de Sintra possui uma tapeçaria fabricada na Flandres no século XVI, de assunto não identificado, que pertenceu a uma série da História de Júlio César ${ }^{3}$ Quanto é do nosso conhecimento, tratase da única peça alusiva ao chefe romano, embora as colecçóes públicas possuam outras tapeçarias que representam episódios, ainda não identificados, da história de Roma (por exemplo, o Museu de Francisco Tavares Proença Júnior, de Castelo Branco).

Estão muito mais representados nas colecçóes públicas de Portugal dois ciclos temáticos que foram extremamente famosos na Europa ocidental:

- a História de Marco António, da qual se conservam

${ }^{2}$ Delmarcel (1998) 155, 231, 312, 328, 333, 367, 369.

${ }_{3}^{3}$ Vide Mendonça (1983) 182-183; http://pnsintra.imc-ip.pt/ pt-PT/coleccoes/HighlightList.aspx (acedido em 25/07/2010). 
várias tapeçarias no Museu Nacional de Arte Antiga e no Palácio dos Duques de Bragança (de Vila Viçosa) ${ }^{4}$.

- a História de Alexandre, o Grande, que integra as colecçóes dos mesmos museus, mas também do Museu de Lamego, do Palácio Nacional da Ajuda e do Palácio Nacional de Mafra.

$\mathrm{Na}$ análise destas peças, Maria José de Mendonça regista $(1983,56)$ que as tapeçarias Alexandre acaba de domar Encéfalos [sic] e A Batalha de Granico do Museu Nacional de Arte Antiga, que pertencem à armação História de Alexandre, realizada no séc. XVIII a partir do pintor francês Charles Le Brun (1619-1690), se baseiam directamente em Plutarco5. É quase certo que muitas outras tapeçarias se inspiram na sua obra, quer nas Vidas Paralelas quer nos Moralia.

${ }^{4}$ Vide Mendonça (1983) 49-56, 216-217.

${ }^{5}$ Cf. R. Vanhoren (1999), «Tapisseries bruxelloises d'après les modèles de Charles Le Brun: L'Histoire d'Alexandre le Grand», in C. Arminjon et N. de Reyniès (dir.), La tapisserie au XVII siècle et les collections européennes. Paris, Éditions du Patrimoine, 61-68. 


\section{UM PERCURSO TEMÁTICO NO TEMPO: as Vidas Paralelas de Plutarco e a pintura EUROPEIA DO SÉCULO XVI AO SÉCULO XIX. \\ Primeiras Abordagens}

Paulo Simóes Rodrigues 
(Página deixada propositadamente em branco) 


\section{UM PERCURSO TEMÁTICO NO TEMPO: \\ As Vidas Paralelas de Plutarco e a pintura \\ EUROPEIA DO SÉCULO XVI AO SÉCULO XIX. \\ Primeiras Abordagens}

Paulo Simões Rodrigues

(Universidade de Évora)

O objecto do presente estudo é proceder a uma primeira abordagem da análise das Vidas Paralelas de Plutarco enquanto fonte e tema da pintura de história, numa baliza cronológica de longa duração que vai do século XV ao século XVIII. Salientamos o critério pré-definido da longa duração porque radica nele a natureza introdutória da análise que aqui nos propomos fazer. Introdutório porque nos interessa entender de que modo as figuras retratadas nas Vidas Paralelas de Plutarco e os episódios com elas relacionados aí narrados se constituíram, enquanto tema de pintura, na representação de uma ideia de história que, independentemente das contingências circunstanciais que envolveram a produção de cada obra que tomou Plutarco como referência temática ou do sentido concreto que cada autor conferiu à personagem ou ao episódio seleccionado, parece ser estruturante de um conceito de temporalidade evolutiva, cumulativa e civilizadora, iniciada no Renascimento e que ainda perdura.

No início do Renascimento, a partir de finais do século XIV, o conceito teológico de tempo predominante na Idade Média, subordinado a uma 
noção transiente da vida terrena, passou a coexistir com uma consciência do tempo enquanto dimensão da acção, da descoberta e da transformação. Nesta nova consciência do tempo, consolida-se a convicção de que o passado estruturou o presente, assim como o presente deverá estruturar o futuro, que se virá a tornar num novo presente, numa linha contínua, irreversível e progressiva em que a experiência humana se vai acumulando, fazendo da modernidade o «anão que está em cima dos ombros de um gigante e por isso é capaz de ver mais longe» ${ }^{1}$, em conformidade com a máxima atribuída a Bernard de Chartres (séc. XII). Mesmo quando essa construção de futuro foi baseada numa pretensa Idade de Ouro passada, nunca esteve em causa um regresso a esse momento primordial, mas a recuperação e a actualização de um modelo de cultura, de moral e de sociedade. Daí considerarmos que esta apropriação do passado como referência estruturante do futuro não implica necessariamente uma perspectiva circular da história, podendo ser cíclica ou em «espiral simbolicamente ascendente» ${ }^{2}$. A divisão da história ocidental nas três eras da Antiguidade, Idade Média e Modernidade, que data dos primórdios do Renascimento, implica esta perspectiva cíclica do tempo.

No que diz respeito à pintura de temática plutarquiana, em concreto à alusiva às Vidas Paralelas, interessa-nos partir da continuidade e da frequência

\footnotetext{
${ }^{1}$ Calinescu (1999) 27.

${ }^{2}$ Calinescu (1999) 25-38.
} 
com que a ela se recorreu no tempo longo, do século XVI ao século XIX, para compreender em que medida foi, mais que a mera ilustração de uma narrativa, um instrumento de consciencialização da realidade em construção que é o presente e o futuro próximo. Mas também de legitimação, pela apresentação de exemplos de personagens e acontecimentos do passado, das opções tomadas na consubstanciação desse presente e na preparação desse futuro. Em suma, a pintura de história enquanto representação visual de uma relação com o tempo e designadamente a pintura de temática plutarquiana enquanto imagem do sentido de uma determinada interpretação da História.

Ao revelar uma perspectiva do tempo e uma ideia da História numa imagem, o pintor está a atribuir-lhes uma dimensão sensorial que as transforma numa experiência para o espectador, ou seja numa realidade mais concreta que a abstracta narrativa dos acontecimentos e até que a materialidade dos vestígios arqueológicos e dos monumentos históricos, na medida em que é a acção dos eventos e a figuração das personagens a que a informação histórica se refere que estão ali perante o observador. $\mathrm{O}$ elevado grau de verosimilhança e dramaticidade que muitas destas pinturas atingiram levam, quando exibidas, a que o espectador se identifique com as cenas representadas, o que as consagra, dentro da dialéctica emotiva, estética e retórica que estabelece com quem as observa, como verdade histórica. Neste sentido, curioso o paralelismo que podemos estabelecer com 
a biografia enquanto género histórico, na medida em que a organização da cadeia de acontecimentos a que alude não está subordinada às relações de causa e efeito, mas à caracterização do biografado e ao seu papel no desenrolar dos factos. Ao centrar a perspectiva de relação com o tempo no ponto de vista de um indivíduo, daquele sobre quem se escreve ${ }^{3}$, a biografia faz com que a compreensão do significado histórico dos eventos protagonizados pelo biografado seja determinada pela intensidade da identificação que o leitor estabeleça com essa personagem cuja vida está a ser narrada. Deste modo, existe sempre a poderosa possibilidade da verdade histórica ser a verdade do biógrafo, tanto como na pintura de história pode ser a do pintor. Biografia e pintura de história são espécies ambíguas, a metade do caminho entre a história e a ficção novelesca ou a representação artística ${ }^{4}$. Afirmam uma finalidade política, moral ou religiosa que ganha estilização e tipificação na personalidade ou no facto a ela ligada, e vêm ao encontro da curiosidade do público pelas figuras heróicas, representativas e exemplares, e à sua necessidade de se identificarem com personagens consideradas superiores. De ressalvar, contudo, que enquanto o registo literário da biografia permite fazer o inventário dos acontecimentos protagonizados pelo biografado dentro do processo histórico, a pintura tem de seleccionar e concentrar a atenção do espectador num acontecimento ou numa acção.

${ }^{3}$ Rodrigues (2002) 127-128.

${ }^{4}$ Bauzá (2002) 183. 
No seu tratado Da Pintura (1435) $)^{5}$ o arquitecto renascentista Leon Battista Alberti afirma que o objecto da pintura é a historia, considerando-a, a bistoria, o maior feito do pintor ${ }^{6}$. De acordo com a historiografia, historia ou istoria foi um termo usado pela primeira vez, no contexto da produção pictórica, no século XV. A sua aplicação veio designar os novos e complexos temas narrativos que por essa altura começaram a enriquecer o reportório dos pintores ${ }^{7}$. Ao concentrar a pintura no conceito de historia, Alberti parece entender a pintura como uma narrativa visual, com muitas figuras, de temáticas que iam da religião aos acontecimentos recentes. Alberti atribui esta relevância narrativa à pintura para estabelecer uma analogia com a retórica clássica, à maneira de Cícero e Quintiliano, de modo a elevar a pintura ao estatuto de actividade intelectual, ou de arte liberal, e, por consequência, fazer ascender o lugar do pintor na sociedade, que assim deixava de ser um mero artista manual, embora o fosse de nível superior. À semelhança da poesia, a pintura devia interpretar e representar as emoções humanas organizando as figuras e os elementos nos diferentes planos da composição pictórica como palavras numa frase poética. Daí a necessidade do artista conceber a pintura na sua imaginação antes de a executar, o que

${ }^{5}$ Escrito originalmente em latim, provavelmente entre 1438 e 1444, foi dedicado a Giovanfrancesco Gonzaga de Mântua. Traduzido para italiano corrente, para o arquitecto florentino Filippo Brunelleschi, por volta de Julho de 1436. Grayson (1972) 3.

${ }^{6}$ Alberti, Da Pintura I, 33 e 60.

${ }^{7}$ Emison (1996) 613-615. 
significa que a pintura era, em primeiro lugar, ideia, o que fazia dela uma actividade mental.

A fim de demonstrar a superioridade intelectual da arte da pintura, muitos teóricos renascentistas, entre os quais está Leonardo da Vinci, defenderam que os pintores deviam pintar apenas seres superiores, deuses e heróis. Deriva desta convicção a frequente associação do termo historia aos temas da Antiguidade clássica, retirados das fontes literárias, considerados os mais exaltantes e exigentes, aqueles que melhor conduziam à edificação do público. Esta atitude, no entanto, também fomentou a generalização das personagens tipificadas, em detrimento da composição de personagens específicas, situação que nos conduz à problematização da acepção do conceito albertiano de historia, tal como foi compreendido pela cultura artística renascentista e pelas suas derivações, e pela própria historiografia. Designadamente a correspondência estabelecida da historia com o tema ou discurso narrativo da pintura, que consideramos redutora em relação à explicitação do termo empreendida pelo próprio Alberti no Da Pintura.

Segundo Alberti, uma historia que se pode verdadeiramente admirar é aquela que se mostre por si mesma tão atractiva e adornada que prenda os olhos do espectador, do instruído e do não instruído, durante muito tempo, com prazer e emoção. $\mathrm{O}$ primeiro aspecto a criar prazer numa historia é a abundância e a variedade dos elementos figurados na pintura. Uma historia abundante é aquela que dá a ver, nos seus lugares apropriados, envolvidos, de modo adequado 
ao que se quer dar a ver, velhos, homens, adolescentes, crianças, matronas, raparigas, recém-nascidos, animais domésticos, cães, aves, cavalos, cordeiros, edifícios, territórios, etc ${ }^{8}$.

Alberti aprofunda o conceito especificando que a historia comove os ânimos dos espectadores quando as emoções das personagens representadas são expressas com clareza e verosimilhança, permitindo que observador se identifique com o que está a observar e, nas palavras do próprio arquitecto italiano, chore com os que choram, ria com os que riem, sofra com os que sofram. Essa clareza e verosimilhança das emoções deve manifestar-se nos movimentos do corpo. Assim, os tristes, perturbados pelas preocupações e obcecados pela aflição, revelam-se entorpecidos em todos os seus sentidos e forças, pálidos, lânguidos e com os membros vacilantes; os que se lamentam apresentam-se com a face congestionada, o pescoço lânguido, fatigados e descuidados; os zangados, cujas paixões estão acesas pela ira, mostram-se com o rosto e os olhos marcados pela cólera, e com movimentos violentos e agitados, em conformidade com o furor da sua irascibilidade; nos alegres e joviais, os movimentos são soltos e agradáveis 9 .

A exposição que Alberti faz do significado que atribui ao termo historia demonstra que este é mais que o tema da pintura, é a acção, o que vai ao encontro do defendido pela poética aristotélica, de que a acção

${ }^{8}$ Alberti, Da Pintura I, 40.

${ }^{9}$ Alberti, Da Pintura I, 40-41. 
humana é o objecto de pintores e poetas ${ }^{10}$. Mas a acção entendida como o processo dinâmico de transmissão do tema que representado pela pintura inclui a maneira como é composto formalmente e configurado, ou seja como se materializa pela intermediação da figuração. Esta noção era particularmente relevante porque, no que concerne à pintura renascentista, ao contrário do que sucedia para a Arquitectura e a Escultura, não existiam modelos temáticos e formais antigos, quer na tratadística - como os Dez Livros de Arquitectura de Vitrúvio - quer na Arqueologia - como as ruínas e as esculturas que podiam ser admiradas e copiadas pelos artistas. Desta situação decorreu o predomínio dos modelos da arquitectura e da escultura na cultura artística moderna, a importância do desenho no esquema compositivo da pintura e a concentração do debate teórico nas problemáticas da representação dos objectos no espaço e da verosimilhança em relação à natureza ${ }^{11}$. O português Francisco de Holanda demonstra-o em 1548, quando descreve o que devia ser a composição da acção numa obra pictórica alusiva à conquista da cidade de Tróia pelos Gregos:

E assim mesmo mostra mui presente e vesivelmente todo aquelle incendio d'aquella cidade, em todas as suas partes, representado e visto tấo igualmente como se fosse mui vero: d'uma banda os que fogem polas ruas e praças: da outra os que laçam dos muros e torres; d'outra parte os templos meio derribados e o resplendor da flama sobre

${ }^{10}$ Aristóteles, Poética 1448a1-5.

${ }^{11}$ Villa (1999) 27. 
os rios; as praias sigeas alumiadas; Pantho como foge com os idolos manquejando, trazendo pola mão seu neto; o cavallo troiano como pare os armados no meo de uma gram praça... [...] Parece-vos que cheiraes o fumo, que fugis da flama, que temeis as ruinas dos edificios; estaes para dar a mão aos que caem, staes para defender aos que pelejam com muitos; para fugir com os que fogem, e para star firme com os esforçados ${ }^{12}$.

No texto, está muito presente a noção da história vivenciada, que apela à emoção e ao sentimento (pathos), o que na pintura é relevante, pois os modelos clássicos seguidos, de origem literária, eram algo mais teórico e emotivo do que concreto e objectual.

O entendimento da pintura enquanto acção é fundamental para compreendermos a relevância que a pintura de história - aqui no sentido de conjunto de conhecimentos relativos ao passado - vai ganhar nos séculos seguintes. Ainda tomando Alberti como referência, salientamos a sua afirmação de que a pintura tem em si uma força tão divina que não só torna presentes os ausentes, como apresenta aqueles que morreram há séculos com a aparência de vivos e de um modo que faz com que sejam reconhecidos pelos espectadores com prazer e suma admiração pelo artista. Alberti recorre precisamente ao exemplo de Plutarco, às biografias que o autor grego escreveu de Alexandre da Macedónia e de Agesilau para demonstrar como a arte, e em particular a pintura, pode preservar os rostos dos defuntos durante muito

${ }^{12}$ Holanda (1984a) 271-272. 
tempo, concedendo-lhes uma espécie de imortalidade que aproxima os mortais dos deuses ${ }^{13}$. Plutarco conta como um dos comandantes de Alexandre, Cassandro, tremeu ao reconhecer a majestade do seu rei defunto num retrato ${ }^{14}$ e que o lacedemónio Agesilau nunca quis ser pintado ou esculpido por estar consciente de uma sua deformidade física, recusando que o conhecimento da sua efígie passasse à posteridade ${ }^{15}$.

Cerca de 63 anos depois de Alberti, por volta de 1498, o pintor Leonardo da Vinci escrevia que se o poeta narrava uma história com a pintura da sua pena, o pintor fazia-o com o seu pincel, mais deleitosa e menos árdua de entender ${ }^{16}$. Na centúria seguinte, Francisco de Holanda referia que a pintura mostrava presentes os «varões que há tanto tempo que passaram, e de que já não aparecem nem os ossos sobre a terra para os podermos imitar em seus feitos claros? Nem de como nos mostra seus conselhos e batalhas, por exemplos e histórias deleitosas, seus actos fortes, sua piedade e costumes?». Dava a ver «os trajos peregrinos ou antigos, a variedade das gentes e nações estranhas, dos edifícios, das alimárias e monstros, que em escritos seriam prolixos de ouvir, e enfim mal entendidos». A pintura punha diante dos olhos «a imagem de qualquer grande homem, por seus feitos desejado de ser visto e conhecido...» ${ }^{17}$.

Até ao final da primeira metade da centúria de

13 Alberti II, 25.

${ }^{14}$ Plutarco, Alexandre 74.4-6.

${ }^{15}$ Plutarco, Agesilau 2.2-4.

${ }^{16}$ Vinci 23, Urb. 8a, 9 a.

${ }^{17}$ Holanda (1984b) 34. Citação do Primeiro Diálogo. 
XIX, a pintura de história esteve ao serviço de uma afirmação de historicidade por parte de elites que quiseram asseverar a sua própria responsabilidade histórica, embora com finalidades distintas, ao sabor das circunstâncias de cada época. De finais do século XIV ao século XVI, durante todo o Renascimento clássico, a pintura de história foi influenciada pela concepção dominante de Antiguidade: um mundo heróico ideal, habitado por heróis convertidos em exemplos a imitar, patente, por exemplo, em De Viris Illustrium de Petrarca. Este era um tema particularmente pertinente na Península Itálica, onde os poderes políticos se consideravam herdeiros dos imperadores romanos e proliferavam as cidades autónomas, como Florença ou as repúblicas de Veneza e Génova, cuja independência era frequentemente ameaçada por potências superiores, como o Papado ou o Império Sacro-Romano. Compreende-se assim as referências que a arte italiana faz ao passado e aos heróis da Antiguidade, passíveis de serem tomados como exemplos da dedicação à pátria ou à cidade, tão necessária no presente ${ }^{18}$.

$\mathrm{Na}$ primeira metade do século XVI, passa a vigorar uma noção mais conceptual da História, de cariz platónico. Deste modo, a arte do Maneirismo concebe a história como alegoria dos factos e a alegoria como o momento culminante da História, representando-a de uma forma mais dinâmica, de imediata compreensão e efeito sobre o espectador, de

${ }^{18}$ Nieto Alcaide, Checa (1994) 33-44 e 244-250. 
exaltação heróica de quem encomendou a obra ou da temática nela abordada ${ }^{19}$.

No período barroco, sob a influência do ascendente que a poética aristotélica foi adquirindo desde a segunda metade do século XVI, a História passa a ser representada com um sentido de maior verosimilhança e moral. O conceito abstracto da ideia de história chega a ganhar uma aparência naturalista. A História é testemunha da memória e da verdade, devendo ser apresentada na pintura de uma maneira directa, simples e verosímil, alicerçada na realidade Fréart de Cambray defendia que as composições de carácter histórico deviam obedecer do modo mais rigoroso à verdade estrita. A expectativa em relação ao cumprimento destes preceitos era tão impositiva que alguns pintores viram-se obrigados a esclarecer a fronteira que separava a criação artística com base no conhecimento histórico da história. O pintor francês Nicolas Poussin respondeu às críticas feitas a determinadas inexactidões históricas detectadas em algumas das suas obras esclarecendo que o artista era livre de representar as coisas como foram no passado e como eram no presente, ou como deviam ter sido nesses dois momentos. Um outro pintor francês, Charles Le Brun, ao comentar uma pintura de Poussin numa sessão da Academia, justificava as liberdades artísticas distinguindo os modos de expressão do historiador e do pintor. Enquanto o primeiro podia, ao longo do seu discurso, apresentar sucessivamente os diferentes

${ }^{19}$ Nieto Alcaide, Checa (1994) 305-316. 
acontecimentos, o segundo tinha que fazer o mesmo num único instante, o do quadro, representando em simultâneo acontecimentos que se haviam desenrolado de modo sucessivo ${ }^{20}$.

Ainda sob os cânones da estética barroca, o século XVII assistiu à autonomização da pintura de história enquanto género pictórico e à sua consagração pela Academia que a elevou à mais alta categoria na ordem dos temas que o pintor podia escolher para trabalhar. A Academia, cuja função institucional era garantir o estatuto social dos pintores, de modo a que não voltassem a ser considerados simples artífices especializados, estabeleceu uma rígida hierarquia dos géneros que era liderada pela pintura de história, seguida pelo retrato, pela pintura de género, pela paisagem e pela natureza-morta ${ }^{21}$. A pintura de história era o mais elevado dos géneros e o mais alto feito a que um pintor podia aspirar porque obrigava a uma profunda modificação da realidade observável. Ao autor de pintura de história não bastava pintar a sua perspectiva das personagens e dos factos, tinha que saber retratar a figura humana de forma convincente e compor as paisagens ou os interiores, incluindo os pormenores dos objectos e dos elementos naturais, que deviam enquadrar as figuras nos cenários adequados

${ }^{20}$ Checa, Morán (1989) 119 e 120.

${ }^{21}$ No século XVII, o conceito de pintura de História abrangia a história profana e religiosa, as narrativas literárias, mitológicas e alegóricas, e os estudos individuais de personagens santas como a Virgem Maria. Pintura de género era a designação atribuída às cenas do quotidiano e que se vulgariza no século XVIII. Walsh (1999) 93. 
à sua condição histórica. As reacções emocionais das personagens tinham de parecer autênticas e corresponder à narração dos acontecimentos a que estavam ligadas.

A aplicação dos preceitos académicos não estava, porém, isenta de debate. Ainda no século XVII, no seio da Academia de São Lucas de Roma, entre os seus membros espoletou uma polémica sobre se os temas históricos deviam ser representados com poucas ou muitas figuras. Classicistas como Sacchi e Nicolas Poussin tendiam para as composições limitadas, nas quais se podia valorizar com clareza cada gesto e cada movimento. Estavam convictos que a mensagem histórica devia ser transmitida por meio da expressão das personagens, devendo estas estar, com essa finalidade, perfeitamente individualizadas e circunscritas no espaço da pintura. Um quadro devia ser lido como um poema ou uma tragédia, em que cada personagem tinha a sua função claramente definida. Igualmente através da comparação da pintura com a poesia - embora não com a tragédia mas com a épica-, alguns pintores, como Pietro de Cortona, sustentaram a antítese, segundo a qual, paralelamente à acção principal, se desenrola toda uma série de episódios secundários, de modo a que a multiplicação de grupos e cenas não dificulte a leitura do conjunto, mas antes enriqueça a composição ${ }^{22}$.

Regulamentada por uma certa ortodoxia estética e iconográfica, necessária à sua eficácia e implícita em certos preceitos do belo e da sua representação,

${ }^{22}$ Checa, Móran (1989) 120 e 121. 
nomeadamente nas obras mais académicas, a pintura de história entra numa fase de estagnação criativa durante a primeira metade do século XVIII, que acarreta a desvalorização do género, até no seio da própria Academia. Em 1727, em França, chega-se a organizar um concurso para estimular a produção de pintura de história. A situação muda a partir de 1760. Estimulada pelos livros de Johann Joachim Winckelmann sobre arte grega e pelo surto das descobertas arqueológicas de Pompeios e Herculano, difundidas por toda a Europa através da gravura, a Antiguidade Clássica recebeu uma renovada atenção. Com a Revolução Francesa (1789), a Antiguidade ganha um novo valor ideológico, tornando-se símbolo apologético dos valores da República e depois, com Napoleão Bonaparte, do Império francês. Os nacionalismos oitocentistas fomentaram ainda mais a pintura de história, mas agora sobretudo ligada aos episódios e às personagens do passado da própria nação, seja relativos ao mais antigo - sobretudo a Idade Média -, seja ao mais recente.

Os limites cronológicos dentro dos quais analisámos o desenvolvimento da pintura de história correspondem, genericamente, às datações que balizam o conjunto de obras de temática plutarquiana que conseguimos recolher, em número de 174 composições, entre iluminuras, pinturas murais e 
telas $^{23}$, que certamente não são a totalidade de pinturas que recorreram às Vidas Paralelas como fonte temática, mas são um universo suficientemente representativo para encetar as primeiras problematizações da relação $\mathrm{da}$ arte com o tempo, numa perspectiva temporal.

Efectivamente, as obras mais antigas que identificámos terão sido realizadas por volta de 1410, estão atribuídas a um Mestre de Luçon e são duas iluminuras que aludem a dois episódios retirados da vida de António, um Banquete de Cleópatra ${ }^{24}$ e a Morte de António e Cleópatra ${ }^{25}$. As duas iluminuras fazem parte da tradução francesa de uma obra de Boccaccio, Des cas des nobles hommes et femmes (De casibus uirorum ilustrium), e aparecem no segundo volume, a primeira no fólio 26 e a segunda no fólio 66. A obra inscreve-se num género literário muito em voga no século $X V$, de intenções panegíricas e moralizantes, sem argumento narrativo, seguindo somente a ordem cronológica da vida das personagens retratadas, em conformidade com o modelo biográfico das Vidas Paralelas de Plutarco. Corresponde à visão quatrocentista da Antiguidade enunciada páginas atrás, a de um mundo habitado por heróis exemplares. Em termos formais, salientamos a Morte de António e Cleópatra, síntese visual de dois

${ }^{23}$ Não considerámos sequer outro tipo de registos artísticos além da pintura (mesmo no âmbito das Artes Visuais, como o desenho e a gravura), pois essa tarefa revelar-se-ia verdadeiramente hercúlea, diriamos mesmo impossível de desenvolver individualmente, só ao alcance de uma equipa de investigação, em prazos bem mais alargados.
${ }^{24}$ Plutarco, António 28.
${ }^{25}$ Plutarco, António 74; 76-78; 84-86. 
momentos narrativos autónomos, que a iluminura junta na mesma representação, prática comum na pintura medieval, a de fazer coincidir tempos distintos num único espaço, com a finalidade de tornar a mensagem visual, neste caso o teor moralizante, mais eficaz. Em termos dos sistemas de narratividade na representação artística, é uma solução muito próxima da narrativa de «momento», a qual revela a essência dos dois episódios ${ }^{26}$. Aqui, ao associar dois momentos diferentes, o iluminador revela a causa comum das duas mortes, a ambição política partilhada por António e Cleópatra, e o seu desfecho trágico provocado pela derrota militar infligida por Octávio Augusto.

Quanto à obra mais recente, data de 1899 , intitula-se Vercingétorix rende-se a César e é da autoria de Lionel-Nöel Royer. Esta alude ao episódio da rendição de Vercingétorix, chefe dos Gauleses, descrito por Plutarco na vida de Júlio César. Plutarco conta como Vercingétorix, depois de pegar nas suas armas mais belas e arrear ricamente o seu cavalo, montou-o, deu uma volta em redor de Júlio César, que estava sentado, apeou-se, atirou a sua armadura ao chão e sentou-se aos pés do general romano, mantendo-se imóvel até que o levaram acorrentado para o desfile triunfa ${ }^{27}$. A pintura de Royer detém-se no momento em que Vercingétorix atira a armadura ao chão perante um Júlio César sentado, rodeado pelo seu exército. É bastante fiel ao passo de Plutarco,

${ }^{26}$ Lopes (2003) 45-46.

${ }^{27}$ Plutarco, César 27. 
acrescentado-lhe unicamente a expressão das emoções dos protagonistas, assim como a recriação do ambiente de um campo militar, elementos necessários ao cânone da verosimilhança da pintura de história. Tematicamente, pertence à categoria das pinturas de carácter nacionalista de finais do século XIX, neste caso em contexto francês, mas em que o herói pátrio não se destaca pela vitória na guerra, mas pela dignidade na derrota, perante um inimigo mais numeroso e poderoso.

O período em que se regista a maior produção de pintura de temática histórica baseada nas Vidas Paralelas de Plutarco estende-se do século XVII ao século XVIII (62\% das obras levantadas), com particular incidência no século XVII $(32,2 \%)^{28}$. A verificação destes dados vem ao encontro do que atrás escrevemos sobre a pintura de história, nomeadamente o ter-se consagrado no século XVII enquanto género autónomo e ter sido considerada, ainda nessa centúria, pela Academia, a mais elevada das categorias temáticas da pintura.

No que respeita aos conteúdos temáticos, ou sejà̀ selecção das personagens ou das situações a representar, numa abordagem diacrónica, é de sublinhar em primeiro lugar que os pintores se concentraram numa pequena parcela dos 50 biografados por Plutarco nos livros que constituem o conjunto das Vidas Paralelas. Para além disso, a presença dos latinos é nitidamente superior aos gregos, que muito deverá ao ascendente

${ }^{28}$ Estas percentagens dizem respeito às obras inventariadas no decurso desta investigação, não significando por isso necessariamente valores exaustivos. 
do Império Romano enquanto referente histórico modelar das ideias de República, Império, governo e civilização, desde o Renascimento ao Romantismo.

As representações mais frequentes são, por ordem crescente, as de Rómulo e Remo, Coriolano, Júlio César, Catão, Alexandre e Cleópatra, por vezes associada a duas outras figuras, Marco António e Octávio Augusto. A Cleópatra, caso interessante porque não foi ela a directamente biografada por Plutarco, surgindo pelo papel fulcral que teve nas vidas de Júlio César e Marco António, que na pintura surgem como figuras complementares à da rainha egípcia, regressaremos mais adiante. Por agora, abordaremos as restantes.

Rómulo e Remo, mito fundador de Roma interpretado como realidade factológica, podem estar presentes por evocação, em cenas que fazem parte da sua história, mas em que eles não aparecem, como sucede com os seus progenitores em Marte e Reia Silvia (1616-1617) de Pieter Paulo Rubens ${ }^{29}$. Também pela situação, ou seja na representação de uma situação em que estiveram directamente envolvidos, embora não figurem como protagonistas da composição, sendo mesmo por vezes de difícil identificação. É o que sucede nas diferentes variações do Rapto das Sabinas e da Intervenção das Mulheres Sabinas ${ }^{30}$. Finalmente, os episódios retirados directamente das suas biografias, nomeadamente o momento em que o pastor Fáustulo

\footnotetext{
${ }^{29}$ Cf. Plutarco, Rómulo 1-4.

${ }^{30}$ Cf. Plutarco, Rómulo 14-19.
} 
os encontrou, depois da morte de sua mãe e do seu abandono, para que também morressem ${ }^{31}$. Ou então cenas que tentam figurar fases da vida dos biografados apenas enunciadas pelas fontes e não descritas, mas às quais a pintura deu uma dimensão visual, tornando-a experiência, logo facto. Assim acontece com a infância de Rómulo e Remo em casa de Fáustulo e de sua mulher Aca Larência ${ }^{32}$.

Abordaremos as figuras de Júlio César e Catão em conjunto. Não apenas porque estão ligados historicamente, pelo seu protagonismo nos acontecimentos que levaram ao fim da República romana, no século I a.C., mas também pela analogia do simbolismo que personificaram na arte. Ambos protagonizam uma morte violenta, Catão suicida-se em 46 a.C..$^{33}$, depois de confrontado com a falência da sua luta pela velha ordem republicana, César é assassinado no Senado nos Idos de Março de 44 a.C. por, ao ter introduzido um poder personalizado e autocrático, ser visto como uma ameaça à República ${ }^{34}$. Ambos simbolizam o sacrifício pessoal em nome de ideais políticos, especialmente dos ideais republicanos, o que explica a frequência dos temas das mortes de Catão e de Júlio César no período pós-revolução francesa - vejam-se as obras de Louis-André-Gabriel

${ }^{31}$ Cf. Plutarco, Rómulo 6.

32 Plutarco, Rómulo 4.4-5.

33 Plutarco, Catão-Menor 64-73. A descrição que Plutarco faz do suicídio de Catão é particularmente pormenorizada, dramática e pitoresca. Geiger (1996) 80.

${ }^{34}$ Plutarco, César 62-67. 
Bouchet (1797), Pierre Bouillon (1797) e Vincenzo Camuccini (c. 1800).

Mas, Júlio César é também representado como herói militar - O Triunfo de César (c. 1800) de Vincenzo Camuccinni -, modelo triunfante para líderes políticos e militares desde a Idade Média à Contemporaneidade. É igualmente o estatuto de herói militar que explica a popularidade de Alexandre da Macedónia, por isso Plutarco põe-no em paralelo com Júlio César, e de Coriolano, aceite como figura real, entre os pintores de História. Em particular, um passo específico nas biografias destes dois heróis. Em relação a Coriolano, os pintores detiveram-se principalmente no momento em que o herói romano avançava sobre Roma à frente do exército volsco e é persuadido a não atacar a cidade por um grupo suplicantes matronas romanas, entre as quais estava a sua mãe e a sua mulher ${ }^{35}$. O tema eleito para Alexandre da Macedónia é a protecção que presta à família do Imperador persa Dario (mãe, mulher e irmã), depois da derrota deste em batalha contra os helenos e da sua morte ${ }^{36}$. Nos dois casos, aquilo que os pintores pretenderam destacar é evidente, uma das qualidades do bom governante, a clemência. De resto, as pinturas alusivas à figura de Alexandre são como que a enumeração das qualidades a um monarca exemplar, enquanto militar (Entrada de Alexandre em Babilónia, Charles Le Brun, c. 1664 ${ }^{37}$ ),

${ }^{35}$ Plutarco, Coriolano 33-36.

${ }^{36}$ Plutarco, Alexandre 21.

${ }^{37}$ Cf. Plutarco, Alexandre 35. 
chefe de família e herdeiro de um património cultural (Alexandre, o Grande e Roxana perante 0 túmulo de Aquiles, Pietro Antonio Rotari, 1756 $6^{38}$ ) e patrono das artes e da cultura (Alexandre, o Grande e Campaspe no estúdio de Apeles, Giovanni Battista Tiepolo, 1725-1726639; Diógenes e Alexandre, Giovanni Battista Langetti, c. $1650^{40}$ ). Tendo em conta que a maioria das obras protagonizadas por Alexandre data dos séculos XVII e XVIII, não podemos deixar de relacionar esta construção da imagem do rei ideal com a construção do Estado moderno e a figura do déspota esclarecido, que teve em Luís XIV da França um dos seus epítomes.

Voltemos ainda a Coriolano para nos determos na obra Coriolano perante a súplica de sua mãe (1650) de Nicolas Poussin ${ }^{41}$, exemplar quanto à relação da narratividade artística com a narrativa biográfica de Plutarco. O mote da narrativa de Plutarco é o discurso da mãe dirigido ao filho, revoltado contra a sua pátria, e que livra Roma da cólera de Coriolano. $\mathrm{O}$ pintor francês realizou um interpretação plástica bastante fiel à descrição feita por Plutarco. As etapas temporais da narrativa são fundidas na densidade imóvel da acção dramática, coreografada como se tratasse de um baixo relevo. Organizando o quadro à volta da confrontação de Coriolano com a sua mãe, Poussin consegue transmitir a importância

\footnotetext{
${ }^{38}$ Cf. Plutarco, Alexandre 15.8-9.

${ }^{39} \mathrm{Cf}$. Plutarco, Alexandre 4.

${ }^{40}$ Cf. Plutarco, Alexandre 14.2-6.

${ }^{41}$ Cf. Plutarco, Coriolano 33-36.
} 
que Plutarco concede à palavra neste episódio que põe fim à revolta do militar romano pelo jogo dos gestos, pelas atitudes e pela articulação plástica entre as figuras ${ }^{42}$.

Regressemos então a Cleópatra, figura transversal à nossa cronologia, feito surpreendente se considerarmos, como dissemos atrás, que não é o objecto das biografias a que está associada - às de Júlio César e Marco António -, mas que na pintura se sobrepõe aos biografados por Plutarco no lugar de protagonista da acção. Por outro lado, há que lembrar que as Vidas Paralelas de Plutarco, pelos factos a que aludem, mesmo se secundariamente participadas por Cleópatra, não deixam de ser uma fonte imprescindível para conhecer a história da última rainha do Egipto. De qualquer modo, a constância com que a imagem de Cleópatra foi reaparecendo na pintura de história durante estes cinco séculos é demonstrativa do seu poder icónico.

Cleópatra é uma figura negativa, é-o na visão moral e ética que Plutarco tem da história e continua a sê-lo a partir do Renascimento, com Boccaccio a abrir a sua vida de Cleópatra no atrás citado $D e$ Mulieribus Claris afirmando que ela conquistou a sua glória por pouco mais que a sua beleza e que ficou conhecida no mundo pela sua ganância, crueldade e luxúria ${ }^{43}$. Mesmo a imagem mais favorável que os anos finais do século XIX empreendem está marcada pela

${ }^{42}$ Fumaroli (1994) 167-169.

${ }^{43}$ Hamer (2001) 302. 
faceta da mulher sedutora e manipuladora, mas que na altura fascinava a cultura simbolista e decadentista finessecular. Deve-se esta imagem à propaganda romana, devidamente mantida e prolongada pela historiografia, que a acusavam de seduzir Júlio César e depois Marco António para manter o trono do Egipto, provocando a impopularidade de ambos os generais romanos e a guerra civil com o segundo. Porquê então a popularidade do mito ao longo do tempo? A explicação parece estar na negatividade das tipologias temáticas com que a arte a imaginou, que têm o seu desfecho no trágico suicídio e que comportam um juízo de valor sobre as consequências dos comportamentos desviantes. Transportaram consigo, nas palavras de Mary Hamer, uma moralidade que pretendia restaurar uma determinada percepção da mulher, oposta ao que o comportamento da rainha egípcia significava ${ }^{44}$.

Os temas mais recorrentes são: César e Cleópatra ${ }^{45}$, os banquetes de Cleópatra ${ }^{46}$, os venenos de Cleópatra ${ }^{47}$, a morte de António ${ }^{48}$, a captura de Cleópatra $^{49}$ e a morte de Cleópatra ${ }^{50}$. Quanto à sua figuração, embora algumas das obras sejam inspiradas directamente nos acontecimentos narrados por Plutarco, são tratadas esquematicamente, sem ter em atenção alguns pormenores dos passos em causa. Outras

${ }^{44}$ Hamer (2001) 304.

${ }^{45}$ Plutarco, César 48.5; 49.

${ }^{46}$ Plutarco, António 28.

47 Plutarco, António 71.

${ }^{48}$ Plutarco, António 74.2-3; 76-78.1.

${ }^{49}$ Plutarco, António 79.

${ }^{50}$ Plutarco, António 84-86. 
ilustram particularidas referidas por Plutarco. Existem ainda aquelas que completam na representação algum aspecto só ligeiramente mencionado por Plutarco ou apenas suposto na situação descrita. A tipologia da morte de Cleópatra, tema de um grande número de obras, permite-nos confirmar a existência dessas possíveis variações. Pois, Plutarco nunca menciona que Cleópatra teria sido mordida no peito pela serpente que utilizou para suicidar-se, refere somente a existência de marcas no braço. A partir deste pormenor, foram realizadas obras em que Cleópatra surge apenas com as marcas no braço, a ser mordida no peito, com os sinais de ter sido mordida no peito e com uma serpente enrolada no braço, ou simplesmente com a serpente enrolada no braço.

São muitas as questões que ficaram por responder, as problemáticas por analisar, as temáticas por abordar e os significados por compreender, nos seus respectivos contextos históricos. No entanto, como afirmámos inicialmente, a reflexão que aqui terminamos corresponde a uma primeira abordagem de um percurso temático no tempo. Ficamos na expectativa das que se seguirão. 


\section{BibLIOGRAFIA}

Alberti, L. B. (1972), On Painting and on Sculpture. The Latin Texts of De Pictura and De Statua. Introd. C. Grayson. New York, Phaidon.

- - (1999), De la pintura y otros escritos sobre arte. Introd. R. de la Villa. Madrid, Editorial Tecnos.

BauzÁ, H. F. (2002), «Humanismo y Acciones en las Vidas de Plutarco" in Plutarco. Educador da Europa. Actas do Congresso. Porto, Fundação Eng. António de Almeida, 181-196.

Calinescu, M. (1999), As 5 Faces da Modernidade. Lisboa, Vega.

Checa, F., Morán, J. M. (1989), El Barroco. Madrid, Ediciones Istmo.

Emison, P. (1996), «Istoria [historia]» in J. Turner, ed., Grove, The Dictionary of Art, vol. 16. London, Macmillan Publishers, 613-615.

FAHY, E. (1971), «Tiepolo's Meeting of Antony and Cleopatra», The Burlington Magazine 113/825, 735-740.

Frazier, F. (1992), «Contribution à l'étude de la composition des "Vies" De Plutarque: l'élaboration des grandes scènes", $A N R W I I .33 .6$, 4488-4535. 
Frazier, F. (1996), Histoire et Morale dans les Vies parallèles de Plutarque. Paris, Les Belles Lettres.

Fumaroli, M. (1994), L'École du Silence. Le Sentiment des Images au XVIIe Siècle. Paris, Flammarion.

Geiger, J. (1996), «Cignaroli's Death of Cato and of Socrates», Zeitschrift für Kunstgeschichte 59/2, 270-278.

Grunchec, P. (1986), Le Peinture à L'École des Beaux-Arts. Les Concours des Prix de Rome (1797-1863), vol. I. [S.1.], École Nationale des Beaux-Arts.

Hamer, M. (2001), "The myth of Cleopatra since the Renaissance» in S. Walker, P. Higgs, eds., Cleopatra of Egypt. From History to Myth. London, The British Museum Press, 302-311.

Hedreen, G. (1994-1995), «SirLawrenceAlma-Tadema’s Women of Amphissa», The Journal of the Walters Art Gallery 52/53, 79-92.

Holanda, F. de (1984a), Da Pintura Antiga. Lisboa, Imprensa Nacional - Casa da Moeda.

__ de (1984b), Diálogos em Roma. Lisboa, Livros Horizonte.

Hughes-Hallett, L. (1990), Cleopatra. Histories, Dreams and Distortions. London, Pimlico. 
Knox, G. (1974), «Giambattista Tiepolo: Variations on the Theme of Anthony and Cleopatra», Master Drawings 12/4, 378-390.

LACY, P. de (1952), «Biography and Tragedy in Plutarch», AJPh 73/2, 159-171.

Lopes, R. O. (2003), «A Função da Imagem Artística Segundo a tradição medieval da Igreja e a prática da pintura portuguesa do Renascimento», Arte Teoria 9, 35-52.

Nieto Alcaide, V., Checa, F. (1993), El Renacimiento. Madrid, Ediciones Istmo.

Pérez Jiménez, A. (1990), «Plutarco y el Humanismo Español del Renacimiento» in A. Pérez Jiménez, G. del Cerro Calderón, eds., Estudios sobre Plutarco: obra y tradición. Málaga, Sociedad Española de Plutarquistas, 229-247.

(2002), «Orientacionesyaproximaciónbibliográfica al proyecto "La recepción de Plutarco desde la Antigüedad hasta el siglo XVII" " in Plutarchus Redivivus. Memorandum del II Encuentro de la Red Temática de Plutarco (Málaga, 1415 de junio de 2001) y Propuesta de Proyectos aprobados. Málaga, Universidad de Málaga, 27-71.

—_ (2002), Plutarchus Rediuiuus. Memorándum del II Encuentro de la Red Temática de Plutarco (Málaga, 14-15 de junio de 2001) y Propuesta 
de Proyectos Aprobados. Málaga, Universidad de Málaga.

ReID, J. D. (1993), The Oxford Guide to Classical Mythology in the Arts, 1300-1990s, vol. I. New York/London, Oxford University Press.

Rodrigues, N. S. (2002), «Plutarco, Historiador dos Lágidas: o Caso de Cleópatra VII Filopator» in Plutarco. Educadorda Europa. Actas do Congresso. Porto, Fundação Eng. António de Almeida, 127-149.

Russell, D. A. (1973), Plutarch. London, Duckworth. Semler, L. E. (2003), «Inigo Jones, Capricious Ornament and Plutarch's Wise Man», Journal of the Warburg and Courtauld Institute 66, 123-142.

Stechow, W. (1945), "The Love of Antiochus with Stratonica in Art», The Art Bulletin 27, 221-237.

Turner, J. ed. (1996), «History Painting» in Grove, The Dictionary of Art, vol. 14. London, Macmillan Publishers, 581-589.

Urbini, S. (1993), "Il mito di Cleopatra. Motivi ed esiti della sua rinnovata fortuna fra Rinascimento e Barocco", Xenia Antiqua 2, 181-222.

VincI, L. da (1998), Tratado de Pintura. Madrid, Ediciones Akal. 
WALSH, L. (1999), "Charles Le Brun, "art dictator of France”» in G. Perry, C. Cunningham, Academies, Museums and Canons of Art. New Haven/London, Yale University Press, 86-123. 


\section{Anexo I}

\section{LISTAGEM DAS OBRAS DE TEMÁTICA BASEADA NAS Vidas Paralelas de Plutarco}

\begin{tabular}{|c|c|c|c|}
\hline Pintor & Título & Ano/Século & $\begin{array}{l}\text { Possível } \\
\text { fonte } \\
\text { plutarquiana }\end{array}$ \\
\hline Аввіаті, Filippo & $\begin{array}{l}\text { Coriolano persuadido } \\
\text { pela sua família a } \\
\text { poupar Roma }\end{array}$ & 1661 & $\begin{array}{l}\text { Vida de } \\
\text { Coriolano }\end{array}$ \\
\hline $\begin{array}{l}\text { ALMA--TADEMA, } \\
\text { Sir Lawrence }\end{array}$ & $\begin{array}{l}\text { O reencontro de } \\
\text { António e Cleópatra, } \\
41 \text { a.C. }\end{array}$ & 1883 & $\begin{array}{l}\text { Vida de } \\
\text { António }\end{array}$ \\
\hline $\begin{array}{l}\text { AltDORFER, } \\
\text { Albrecht }\end{array}$ & $\begin{array}{l}\text { A Batalha de } \\
\text { Alexandre }\end{array}$ & 1529 & $\begin{array}{l}\text { Vida de } \\
\text { Alexandre }\end{array}$ \\
\hline $\begin{array}{l}\text { Amalteo, } \\
\text { Pomponio }\end{array}$ & A morte de Catão & c. 1580 & $\begin{array}{l}\text { Vida de Catão } \\
\text { Menor }\end{array}$ \\
\hline $\begin{array}{l}\text { Anónimo } \\
\text { (Miniaturista } \\
\text { flamengo) }\end{array}$ & $\begin{array}{l}\text { História de } \\
\text { Alexandre, o Grande }\end{array}$ & $1450-1490$ & $\begin{array}{l}\text { Vida de } \\
\text { Alexandre }\end{array}$ \\
\hline $\begin{array}{l}\text { Anónimo } \\
\text { (discípulo de } \\
\text { Nicolas Poussin) }\end{array}$ & Cleópatra e Octávio & Séc. XVII & $\begin{array}{l}\text { Vida de } \\
\text { António }\end{array}$ \\
\hline
\end{tabular}




\begin{tabular}{|c|c|c|c|}
\hline Anónimo & $\begin{array}{l}\text { A Morte de António e } \\
\text { Cleópatra, iluminura } \\
\text { do manuscrito de } \\
\text { Boccaccio (ce), De } \\
\text { casibus uirorum } \\
\text { ilustrium, Des cas } \\
\text { des nobles hommes } \\
\text { et femmes, tradução } \\
\text { francesa de Laurent } \\
\text { de Premiierfait, vol. } \\
\text { II, fol. 190v. }\end{array}$ & $1460-1470$ & $\begin{array}{l}\text { Vida de } \\
\text { António }\end{array}$ \\
\hline $\begin{array}{l}\text { Anónimo } \\
\text { (pintor activo } \\
\text { em Veneza e } \\
\text { Emília no final } \\
\text { do século XVI) }\end{array}$ & $\begin{array}{l}\text { O Suicidio de } \\
\text { Cleópatra }\end{array}$ & c. 1580 & $\begin{array}{l}\text { Vida de } \\
\text { António }\end{array}$ \\
\hline $\begin{array}{l}\text { Assereto, } \\
\text { Gioacchino }\end{array}$ & O suícidio de Catão & c. 1639 & $\begin{array}{l}\text { Vida de Catão } \\
\text { Menor }\end{array}$ \\
\hline $\begin{array}{l}\text { BALESTRA, } \\
\text { Antonio }\end{array}$ & $\begin{array}{l}\text { Teseu descobre a } \\
\text { espada de seu pai }\end{array}$ & $\begin{array}{l}\text { sécs. } \\
\text { XVII-XVIII }\end{array}$ & Vida de Teseu \\
\hline $\begin{array}{l}\text { BARBIERI, } \\
\text { Giovanni } \\
\text { Francesco (dito } \\
\text { Le Guerchin) }\end{array}$ & $\begin{array}{l}\text { Cleópatra perante } \\
\text { Octávio Augusto }\end{array}$ & c. 1640 & $\begin{array}{l}\text { Vida de } \\
\text { António }\end{array}$ \\
\hline Batoni, Pompeo & $\begin{array}{l}\text { A Morte de Marco } \\
\text { António }\end{array}$ & 1763 & $\begin{array}{l}\text { Vida de } \\
\text { António }\end{array}$ \\
\hline $\begin{array}{l}\text { BEAUFORT, } \\
\text { JacquesAntoine }\end{array}$ & $\begin{array}{l}\text { O Juramento de } \\
\text { Bruto }\end{array}$ & 1771 & $\begin{array}{l}\text { Vida de Bruto } \\
\text { Vida de César }\end{array}$ \\
\hline $\begin{array}{l}\text { BeCCAFUMI, } \\
\text { Domenico }\end{array}$ & A morte de Catão & c. 1519 & $\begin{array}{l}\text { Vida de Catão } \\
\text { Menor }\end{array}$ \\
\hline $\begin{array}{l}\text { BisCAINO, } \\
\text { Bartolomeo }\end{array}$ & $\begin{array}{l}\text { Coriolano recebendo } \\
\text { as matronas romanas }\end{array}$ & c. 1725 & $\begin{array}{l}\text { Vida de } \\
\text { Coriolano }\end{array}$ \\
\hline BLANCHARD & $\begin{array}{l}\text { Marte e a Vestal } \\
\text { Virginia }\end{array}$ & c. 1630 & $\begin{array}{l}\text { Vida de } \\
\text { Rómulo (?) }\end{array}$ \\
\hline
\end{tabular}




\begin{tabular}{|c|c|c|c|}
\hline $\begin{array}{l}\text { BöCKLIN, } \\
\text { Arnold }\end{array}$ & A Morte de Cleópatra & 1872 & $\begin{array}{l}\text { Vida de } \\
\text { António }\end{array}$ \\
\hline $\begin{array}{l}\text { BöCKLIN, } \\
\text { Arnold }\end{array}$ & $\begin{array}{l}\text { A Morte de } \\
\text { Cleópatra }\end{array}$ & 1878 & $\begin{array}{l}\text { Vida de } \\
\text { António }\end{array}$ \\
\hline $\begin{array}{l}\text { BoISFREMONT, } \\
\text { Charles-Pompée le } \\
\text { Boulanger de }\end{array}$ & A Morte de Cleópatra & 18241828 & $\begin{array}{l}\text { Vida de } \\
\text { António }\end{array}$ \\
\hline Boisselier, Félix & $\begin{array}{l}\text { A Morte de } \\
\text { Demóstenes }\end{array}$ & 1805 & $\begin{array}{l}\text { Vida de } \\
\text { Nicias }\end{array}$ \\
\hline $\begin{array}{l}\text { BotTICELLI, } \\
\text { Sandro }\end{array}$ & $\begin{array}{l}\text { A História de } \\
\text { Lucrécia }\end{array}$ & $1496 / 1504$ & $\begin{array}{l}\text { Vida de } \\
\text { Publícola (?) }\end{array}$ \\
\hline $\begin{array}{l}\text { Bouchet, Louis } \\
\text { André Gabriel }\end{array}$ & $\begin{array}{l}\text { A morte de Catão de } \\
\text { Útica }\end{array}$ & 1797 & $\begin{array}{l}\text { Vida de Catão } \\
\text { Menor }\end{array}$ \\
\hline $\begin{array}{l}\text { BoullLon, } \\
\text { Pierre }\end{array}$ & $\begin{array}{l}\text { A morte de Catão de } \\
\text { Útica }\end{array}$ & 1797 & $\begin{array}{l}\text { Vida de Catão } \\
\text { Menor }\end{array}$ \\
\hline $\begin{array}{l}\text { Bourdon, } \\
\text { Sébastien }\end{array}$ & $\begin{array}{l}\text { O reencontro de } \\
\text { António e Cleópatra }\end{array}$ & c. 1645 & $\begin{array}{l}\text { Vida de } \\
\text { António }\end{array}$ \\
\hline $\begin{array}{l}\text { BrasCASSAT, } \\
\text { Jacques } \\
\text { Raymond }\end{array}$ & Coriolano e sua mãe & 1831 & $\begin{array}{l}\text { Vida de } \\
\text { Coriolano }\end{array}$ \\
\hline $\begin{array}{l}\text { BRISSET, Pierre- } \\
\text {-Nicolas }\end{array}$ & $\begin{array}{l}\text { A Partida de Gaio } \\
\text { Graco }\end{array}$ & 1840 & $\begin{array}{l}\text { Vida de Gaio } \\
\text { Graco }\end{array}$ \\
\hline $\begin{array}{l}\text { BRUEGHEL, Jan } \\
\text { (o velho) }\end{array}$ & A Batalha de Isso & 1602 & $\begin{array}{l}\text { Vida de } \\
\text { Alexandre }\end{array}$ \\
\hline $\begin{array}{l}\text { BRUSASORCI, } \\
\text { Domenico }\end{array}$ & $\begin{array}{l}\text { O Suicidio de } \\
\text { Cleópatra }\end{array}$ & $1550 / 1555$ & $\begin{array}{l}\text { Vida de } \\
\text { António }\end{array}$ \\
\hline $\begin{array}{l}\text { CABAnel, } \\
\text { Alexandre }\end{array}$ & $\begin{array}{l}\text { Cleópatra ensaiando } \\
\text { os venenos nos } \\
\text { condenados à morte }\end{array}$ & 1887 & $\begin{array}{l}\text { Vida de } \\
\text { António }\end{array}$ \\
\hline $\begin{array}{l}\text { CaDES, } \\
\text { Giuseppe }\end{array}$ & $\begin{array}{l}\text { Alexandre, o Grande } \\
\text { recusa-se a beber água }\end{array}$ & 1792 & $\begin{array}{l}\text { Vida de } \\
\text { Alexandre }\end{array}$ \\
\hline $\begin{array}{l}\text { CagnacCI, } \\
\text { Guido }\end{array}$ & Cleópatra & c. 1659 & $\begin{array}{l}\text { Vida de } \\
\text { António }\end{array}$ \\
\hline
\end{tabular}




\begin{tabular}{|c|c|c|c|}
\hline $\begin{array}{l}\text { CagnaCCI, } \\
\text { Guido }\end{array}$ & A Morte de Cleópatra & $\begin{array}{l}\text { c. } 659 / 1661 \\
/ 1662\end{array}$ & $\begin{array}{l}\text { Vida de } \\
\text { António }\end{array}$ \\
\hline $\begin{array}{l}\text { CAMUCCINI, } \\
\text { Vincenzo }\end{array}$ & $\begin{array}{l}\text { Os Idos de Março / A } \\
\text { morte de César }\end{array}$ & c. 1800 & Vida de César \\
\hline $\begin{array}{l}\text { CAMUCCINI, } \\
\text { Vincenzo }\end{array}$ & O Triunfo de César & c. 1800 & Vida de César \\
\hline $\begin{array}{l}\text { CAMUCCINI, } \\
\text { Vincenzo }\end{array}$ & $\begin{array}{l}\text { Rómulo e Remo } \\
\text { descobertos }\end{array}$ & c. 1800 & $\begin{array}{l}\text { Vida de } \\
\text { Rómulo }\end{array}$ \\
\hline Caravaggio & $\begin{array}{l}\text { Os sete actos de } \\
\text { misericórdia }\end{array}$ & 1607 & $\begin{array}{l}\text { Vida de } \\
\text { Numa (?) }\end{array}$ \\
\hline $\begin{array}{l}\text { Cignaroli, } \\
\text { Giambettino }\end{array}$ & A Morte de Catão & $\begin{array}{l}\text { Séc. XVII } \\
(?)\end{array}$ & $\begin{array}{l}\text { Vida de Catão } \\
\text { Menor }\end{array}$ \\
\hline Collier, John & A Morte de Cleópatra & 1890 & $\begin{array}{l}\text { Vida de } \\
\text { António }\end{array}$ \\
\hline $\begin{array}{l}\text { Conca, } \\
\text { Sebastiano }\end{array}$ & $\begin{array}{l}\text { Alexandre, o Grande } \\
\text { no Templo de } \\
\text { Jerusalém }\end{array}$ & $1735-1737$ & $\begin{array}{l}\text { Vida de } \\
\text { Alexandre (?) }\end{array}$ \\
\hline $\begin{array}{l}\text { Cortona, Pietro } \\
\text { de }\end{array}$ & $\begin{array}{l}\text { O Rapto das } \\
\text { Mulheres Sabinas }\end{array}$ & $1627-1629$ & $\begin{array}{l}\text { Vida de } \\
\text { Rómulo }\end{array}$ \\
\hline $\begin{array}{l}\text { Cortona, Pietro } \\
\text { de }\end{array}$ & $\begin{array}{l}\text { Rómulo e Remo } \\
\text { acolhidos por } \\
\text { Fáustulo }\end{array}$ & c. 1643 & $\begin{array}{l}\text { Vida de } \\
\text { Rómulo }\end{array}$ \\
\hline $\begin{array}{l}\text { Cozza, } \\
\text { Francesco }\end{array}$ & $\begin{array}{l}\text { Cleópatra oferecendo- } \\
\text { se à morte }\end{array}$ & 1675 & $\begin{array}{l}\text { Vida de } \\
\text { António }\end{array}$ \\
\hline $\begin{array}{l}\text { Crayer, Gaspar } \\
\text { de }\end{array}$ & Alexandre e Diógenes & Séc. XVII & $\begin{array}{l}\text { Vida de } \\
\text { Alexandre }\end{array}$ \\
\hline $\begin{array}{l}\text { DAVID, } \\
\text { JacquesLouis }\end{array}$ & Antioco e Estratonice & 1774 & $\begin{array}{l}\text { Vida de } \\
\text { Demétrio }\end{array}$ \\
\hline $\begin{array}{l}\text { DAVID, } \\
\text { JacquesLouis }\end{array}$ & $\begin{array}{l}\text { Os lictores devolvendo } \\
\text { a Bruto os corpos de } \\
\text { seus filhos }\end{array}$ & 1789 & Vida de Bruto \\
\hline $\begin{array}{l}\text { DAVID, } \\
\text { JacquesLouis }\end{array}$ & $\begin{array}{l}\text { A Intervenção das } \\
\text { Mulheres Sabinas }\end{array}$ & 1799 & $\begin{array}{l}\text { Vida de } \\
\text { Rómulo }\end{array}$ \\
\hline
\end{tabular}




\begin{tabular}{|c|c|c|c|}
\hline $\begin{array}{l}\text { Dejussieu, } \\
\text { Henri Blaise } \\
\text { François }\end{array}$ & $\begin{array}{l}\text { Cleópatra ou } \\
\text { Cleópatra e a escrava }\end{array}$ & 1863 & $\begin{array}{l}\text { Vida de } \\
\text { António }\end{array}$ \\
\hline $\begin{array}{l}\text { DelaCroix, } \\
\text { Eugène }\end{array}$ & $\begin{array}{l}\text { Cleópatra e o } \\
\text { Camponês }\end{array}$ & 1838 & $\begin{array}{l}\text { Vida de } \\
\text { António }\end{array}$ \\
\hline $\begin{array}{l}\text { Diziani, } \\
\text { Gaspare }\end{array}$ & $\begin{array}{l}\text { A familia de Dario } \\
\text { perante Alexandre, o } \\
\text { Grande }\end{array}$ & Séc. XVIII & $\begin{array}{l}\text { Vida de } \\
\text { Alexandre }\end{array}$ \\
\hline DoMENichino & $\begin{array}{l}\text { Timocleia cativa } \\
\text { trazida perante } \\
\text { Alexandre }\end{array}$ & c. 1615 & $\begin{array}{l}\text { Vida de } \\
\text { Alexandre }\end{array}$ \\
\hline $\begin{array}{l}\text { Dupré, } \\
\text { FrançoisXavier }\end{array}$ & $\begin{array}{l}\text { Coriolano na casa de } \\
\text { Tulo, rei dos Volscos }\end{array}$ & 1827 & $\begin{array}{l}\text { Vida de } \\
\text { Coriolano }\end{array}$ \\
\hline $\begin{array}{l}\text { Duvivier, } \\
\text { Johannes } \\
\text { Bernardus }\end{array}$ & $\begin{array}{l}\text { Cleópatra capturada } \\
\text { pelos soldados } \\
\text { romanos após a morte } \\
\text { de Marco António }\end{array}$ & 1789 & $\begin{array}{l}\text { Vida de } \\
\text { António }\end{array}$ \\
\hline $\begin{array}{l}\text { EескоUт, } \\
\text { Gerbrand von } \\
\text { der }\end{array}$ & $\begin{array}{l}\text { Volumnia perante } \\
\text { Coriolano }\end{array}$ & Séc. XVII & $\begin{array}{l}\text { Vida de } \\
\text { Coriolano }\end{array}$ \\
\hline $\begin{array}{l}\text { EvERDINGEN, } \\
\text { Caesar von }\end{array}$ & $\begin{array}{l}\text { Licurgo } \\
\text { demonstrando } \\
\text { os benefícios da } \\
\text { Educação }\end{array}$ & $1660-1662$ & $\begin{array}{l}\text { Vida de } \\
\text { Licurgo }\end{array}$ \\
\hline FERRARI, Luca & A Morte de Cleópatra & c. 1650 & $\begin{array}{l}\text { Vida de } \\
\text { António }\end{array}$ \\
\hline $\begin{array}{l}\text { FESELEN, } \\
\text { Melchior }\end{array}$ & $\begin{array}{l}\text { Alésia cercada por } \\
\text { Júlio César }\end{array}$ & Séc. XVI & Vida de César \\
\hline $\begin{array}{l}\text { FLANDRIN, } \\
\text { Hippolyte }\end{array}$ & $\begin{array}{l}\text { Teseu reconhecido por } \\
\text { seu pai }\end{array}$ & 1832 & Vida de Teseu \\
\hline $\begin{array}{l}\text { FONTANA, } \\
\text { Lavinia }\end{array}$ & Cleópatra & c. 1585 & $\begin{array}{l}\text { Vida de } \\
\text { António }\end{array}$ \\
\hline Foppa, Vicenzo & $\begin{array}{l}\text { A leitura do menino } \\
\text { Cícero }\end{array}$ & c. 1464 & $\begin{array}{l}\text { Vida de } \\
\text { Cícero }\end{array}$ \\
\hline
\end{tabular}




\begin{tabular}{|c|c|c|c|}
\hline FouQueT, Jean & $\begin{array}{l}\text { A fuga de Pompeio } \\
\text { depois da batalha de } \\
\text { Farsália }\end{array}$ & Séc. XV & $\begin{array}{l}\text { Vida de } \\
\text { Pompeio } \\
\text { Vida de César }\end{array}$ \\
\hline FouQUET, Jean & $\begin{array}{l}\text { César atravessando o } \\
\text { Rubicão }\end{array}$ & Séc. XV & Vida de César \\
\hline Gauffier, Louis & $\begin{array}{l}\text { Rómulo em Remo em } \\
\text { casa de Fáustulo e } \\
\text { Aca Larência }\end{array}$ & Séc. XVIII & $\begin{array}{l}\text { Vida de } \\
\text { Rómulo }\end{array}$ \\
\hline Gauffier, Louis & $\begin{array}{l}\text { Entrevista de Augusto } \\
\text { e Cleópatra depois da } \\
\text { batalha de Áccio }\end{array}$ & 1788 & $\begin{array}{l}\text { Vida de } \\
\text { António }\end{array}$ \\
\hline $\begin{array}{l}\text { Gellée, Claude } \\
\text { (dito Le Lorrain) }\end{array}$ & $\begin{array}{l}\text { O desembarque de } \\
\text { Cleópatra em Tarso } \\
\text { ou Páris e Helena } \\
\text { desembarcando em } \\
\text { Tróia }\end{array}$ & 1642 & $\begin{array}{l}\text { Vida de } \\
\text { António }\end{array}$ \\
\hline $\begin{array}{l}\text { Gengu, } \\
\text { Girolamo }\end{array}$ & $\begin{array}{l}\text { O filho de Fábio } \\
\text { Máximo resgatando } \\
\text { os prisioneiros de } \\
\text { Anibal }\end{array}$ & Séc. XVI & $\begin{array}{l}\text { Vida de Fábio } \\
\text { Máximo }\end{array}$ \\
\hline $\begin{array}{l}\text { Gentileschi, } \\
\text { Artemisa }\end{array}$ & Cleópatra & c. 1620 & $\begin{array}{l}\text { Vida de } \\
\text { António }\end{array}$ \\
\hline $\begin{array}{l}\text { GÉRÔME, } \\
\text { JeanLéon }\end{array}$ & A Morte de César & 1867 & Vida de César \\
\hline $\begin{array}{l}\text { GHIRLANDAIO, } \\
\text { Michele di } \\
\text { Ridolfo del }\end{array}$ & $\begin{array}{l}\text { O Suicídio de } \\
\text { Cleópatra }\end{array}$ & c. 1560 & $\begin{array}{l}\text { Vida de } \\
\text { António }\end{array}$ \\
\hline $\begin{array}{l}\text { Gianneti, } \\
\text { Raffaele }\end{array}$ & $\begin{array}{l}\text { O último senado de } \\
\text { Júlio César }\end{array}$ & 1867 & Vida de César \\
\hline $\begin{array}{l}\text { GraVELOT, } \\
\text { Hubert François }\end{array}$ & Augusto e Cleópatra & Séc. XVIII & $\begin{array}{l}\text { Vida de } \\
\text { António }\end{array}$ \\
\hline Guercino & $\begin{array}{l}\text { Hersilia separando } \\
\text { Rómulo de Tácio }\end{array}$ & 1645 & $\begin{array}{l}\text { Vida de } \\
\text { Rómulo }\end{array}$ \\
\hline $\begin{array}{l}\text { GUÉRIN, Pierre- } \\
\text {-Narcisse }\end{array}$ & $\begin{array}{l}\text { A morte de Catão de } \\
\text { Útica }\end{array}$ & 1797 & $\begin{array}{l}\text { Vida de Catão } \\
\text { Menor }\end{array}$ \\
\hline
\end{tabular}




\begin{tabular}{|c|c|c|c|}
\hline $\begin{array}{l}\text { GuÉRIN, Pierre- } \\
\text {-Narcisse }\end{array}$ & $\begin{array}{l}\text { O Casamento de } \\
\text { Alexandre, o Grande } \\
\text { e Roxana }\end{array}$ & Séc. XIX & $\begin{array}{l}\text { Vida de } \\
\text { Alexandre }\end{array}$ \\
\hline Hallé, Noël & $\begin{array}{l}\text { Cornélia mäe dos } \\
\text { Gracos }\end{array}$ & 1779 & $\begin{array}{l}\text { Vida Gaio } \\
\text { Graco } \\
\text { Vida de } \\
\text { Tibério Graco }\end{array}$ \\
\hline $\begin{array}{l}\text { Hamilton, } \\
\text { Gavin }\end{array}$ & $\begin{array}{l}\text { O Juramento de } \\
\text { Bruto }\end{array}$ & $1763-1764$ & Vida de Bruto \\
\hline $\begin{array}{l}\text { HAMilton, } \\
\text { Gavin }\end{array}$ & Cleópatra & $1767-1769$ & $\begin{array}{l}\text { Vida de } \\
\text { António }\end{array}$ \\
\hline $\begin{array}{l}\text { Heim, François- } \\
\text {-Joseph }\end{array}$ & $\begin{array}{l}\text { Teseu vencedor do } \\
\text { Minotauro }\end{array}$ & 1807 & $\begin{array}{l}\text { Vida de Teseu } \\
\text { (?) }\end{array}$ \\
\hline $\begin{array}{l}\text { HILLEMACHER, } \\
\text { Eugéne Ernest }\end{array}$ & $\begin{array}{l}\text { António moribundo } \\
\text { levado até Cleópatra }\end{array}$ & 1863 & $\begin{array}{l}\text { Vida de } \\
\text { António }\end{array}$ \\
\hline $\begin{array}{l}\text { Hire, Laurent } \\
\text { de La }\end{array}$ & Teseu e Etra & $1635-1640$ & Vida de Teseu \\
\hline $\begin{array}{l}\text { Hire, Laurent } \\
\text { de La }\end{array}$ & $\begin{array}{l}\text { Cornélia recusa a } \\
\text { coroa de Ptolemeu }\end{array}$ & 1646 & $\begin{array}{l}\text { Vida de } \\
\text { Tibério Graco }\end{array}$ \\
\hline Hoet, Gérard & A Morte de Cleópatra & Séc. XVIII & $\begin{array}{l}\text { Vida de } \\
\text { António }\end{array}$ \\
\hline $\begin{array}{l}\text { HONTHORST, } \\
\text { Gerrit von }\end{array}$ & Solón e Creso & 1624 & Vida de Sólon \\
\hline $\begin{array}{l}\text { INGRES, Jean- } \\
\text {-Auguste }\end{array}$ & Antioco e Estratonice & 1840 & $\begin{array}{l}\text { Vida de } \\
\text { Demétrio }\end{array}$ \\
\hline $\begin{array}{l}\text { JACOPO, } \\
\text { Giovanni } \\
\text { Battista } \\
\text { (dito Il Rosso } \\
\text { Fiorentino) }\end{array}$ & A Morte de Cleópatra & $1524-1527$ & $\begin{array}{l}\text { Vida de } \\
\text { António }\end{array}$ \\
\hline JoRDAENS, Jacob & A Morte de Cleópatra & 1653 & $\begin{array}{l}\text { Vida de } \\
\text { António }\end{array}$ \\
\hline
\end{tabular}




\begin{tabular}{|c|c|c|c|}
\hline $\begin{array}{l}\text { KauffmanN, } \\
\text { Angelika }\end{array}$ & $\begin{array}{l}\text { Cleópatra decorando } \\
\text { o túmulo de Marco } \\
\text { António }\end{array}$ & $1769-1770$ & $\begin{array}{l}\text { Vida de } \\
\text { António }\end{array}$ \\
\hline Lacour, Pierre & $\begin{array}{l}\text { Cleópatra } \\
\text { lamentando-se no } \\
\text { túmulo de Marco } \\
\text { António }\end{array}$ & 1781 & $\begin{array}{l}\text { Vida de } \\
\text { António }\end{array}$ \\
\hline $\begin{array}{l}\text { LAIRESSE, Gérard } \\
\text { de }\end{array}$ & $\begin{array}{l}\text { O banquete de } \\
\text { Cleópatra }\end{array}$ & c. 1675 & $\begin{array}{l}\text { Vida de } \\
\text { António }\end{array}$ \\
\hline $\begin{array}{l}\text { LAIRESSE, Gérard } \\
\text { de }\end{array}$ & A Morte de Cleópatra & $1675-1680$ & $\begin{array}{l}\text { Vida de } \\
\text { António }\end{array}$ \\
\hline $\begin{array}{l}\text { LAIRESSE, Gérard } \\
\text { de }\end{array}$ & $\begin{array}{l}\text { O desembarque de } \\
\text { Cleópatra em Tarso } \\
\text { ou Páris e Helena } \\
\text { desembarcando em } \\
\text { Tróia }\end{array}$ & $1685-1690$ & $\begin{array}{l}\text { Vida de } \\
\text { António }\end{array}$ \\
\hline $\begin{array}{l}\text { LANGETTI, } \\
\text { Giovanni } \\
\text { Battista }\end{array}$ & Catâo & $1660-1680$ & $\begin{array}{l}\text { Vida de Catão } \\
\text { Menor }\end{array}$ \\
\hline $\begin{array}{l}\text { LANGETTI, } \\
\text { Giovanni } \\
\text { Battista }\end{array}$ & Diógenes e Alexandre & c. 1650 & $\begin{array}{l}\text { Vida de } \\
\text { Alexandre }\end{array}$ \\
\hline $\begin{array}{l}\text { LARIVIÈRE, } \\
\text { Charles Philippe- } \\
\text {-Auguste }\end{array}$ & $\begin{array}{l}\text { A Morte de } \\
\text { Alcibiades }\end{array}$ & 1824 & $\begin{array}{l}\text { Vida de } \\
\text { Alcibiades }\end{array}$ \\
\hline $\begin{array}{l}\text { Le Brun, } \\
\text { Charles }\end{array}$ & $\begin{array}{l}\text { A familia de Dario } \\
\text { perante Alexandre }\end{array}$ & c. 1660 & $\begin{array}{l}\text { Vida de } \\
\text { Alexandre }\end{array}$ \\
\hline $\begin{array}{l}\text { Le Brun, } \\
\text { Charles }\end{array}$ & $\begin{array}{l}\text { Entrada de Alexandre } \\
\text { em Babilónia }\end{array}$ & c. 1664 & $\begin{array}{l}\text { Vida de } \\
\text { Alexandre }\end{array}$ \\
\hline $\begin{array}{l}\text { LE Brun, } \\
\text { Charles }\end{array}$ & Alexandre e Poro & 1665 & $\begin{array}{l}\text { Vida de } \\
\text { Alexandre }\end{array}$ \\
\hline $\begin{array}{l}\text { LETHIÈRE, } \\
\text { Guillaume }\end{array}$ & $\begin{array}{l}\text { A morte de Catão em } \\
\text { Útica }\end{array}$ & 1795 & $\begin{array}{l}\text { Vida de Catão } \\
\text { Menor }\end{array}$ \\
\hline Liss, Johann & A Morte de Cleópatra & $1622-1624$ & $\begin{array}{l}\text { Vida de } \\
\text { António }\end{array}$ \\
\hline
\end{tabular}




\begin{tabular}{|c|c|c|c|}
\hline $\begin{array}{l}\text { Luçon, Mestre } \\
\text { de }\end{array}$ & $\begin{array}{l}\text { Banquete de } \\
\text { Cleópatra, } \\
\text { iluminura do } \\
\text { manuscrito de } \\
\text { Boccaccio (ce), Des } \\
\text { casibus virorum } \\
\text { ilustrium, Des cas } \\
\text { des nobles hommes } \\
\text { et femmes, traduçấo } \\
\text { francesa de Laurent } \\
\text { de Premiierfait, vol. } \\
\text { II, fol. } 26\end{array}$ & c. 1410 & $\begin{array}{l}\text { Vida de } \\
\text { António }\end{array}$ \\
\hline $\begin{array}{l}\text { Luçon, Mestre } \\
\text { de }\end{array}$ & $\begin{array}{l}\text { A Morte de António e } \\
\text { Cleópatra, iluminura } \\
\text { do manuscrito de } \\
\text { Boccaccio (ce), Des } \\
\text { casibus virorum } \\
\text { ilustrium, Des cas } \\
\text { des nobles hommes } \\
\text { et femmes, tradução } \\
\text { francesa de Laurent } \\
\text { de Premiierfait, vol. } \\
\text { II, fol. } 66\end{array}$ & c. 1410 & $\begin{array}{l}\text { Vida de } \\
\text { António }\end{array}$ \\
\hline MAKART, Hans & A Morte de Cleópatra & 1875 & $\begin{array}{l}\text { Vida de } \\
\text { António }\end{array}$ \\
\hline $\begin{array}{l}\text { MANTEGNA, } \\
\text { Andrea }\end{array}$ & O Triunfo de César & dp. 1486 & Vida de César \\
\hline $\begin{array}{l}\text { Mazzoni, } \\
\text { Sebastiano }\end{array}$ & A Morte de Cleópatra & 1660 & $\begin{array}{l}\text { Vida de } \\
\text { António }\end{array}$ \\
\hline $\begin{array}{l}\text { MÉNAGEOT, } \\
\text { François } \\
\text { Guillaume }\end{array}$ & $\begin{array}{l}\text { Cleópatra no túmulo } \\
\text { de Marco António }\end{array}$ & 1785 & $\begin{array}{l}\text { Vida de } \\
\text { António }\end{array}$ \\
\hline $\begin{array}{l}\text { Mengs, Anton } \\
\text { Raphael }\end{array}$ & Augusto e Cleópatra & 1759 & $\begin{array}{l}\text { Vida de } \\
\text { António }\end{array}$ \\
\hline $\begin{array}{l}\text { Mengs, Anton } \\
\text { Raphael }\end{array}$ & Augusto e Cleópatra & 1760 & $\begin{array}{l}\text { Vida de } \\
\text { António }\end{array}$ \\
\hline
\end{tabular}




\begin{tabular}{|c|c|c|c|}
\hline Mignard, Pierre & A Morte de Cleópatra & Séc. XVII & $\begin{array}{l}\text { Vida de } \\
\text { António }\end{array}$ \\
\hline $\begin{array}{l}\text { Moreau, } \\
\text { Gustave }\end{array}$ & $\begin{array}{l}\text { O Triunfo de } \\
\text { Alexandre, o Grande }\end{array}$ & c. 1885 & $\begin{array}{l}\text { Vida de } \\
\text { Alexandre }\end{array}$ \\
\hline $\begin{array}{l}\text { Natolre, } \\
\text { CharlesJoseph }\end{array}$ & $\begin{array}{l}\text { O reencontro de } \\
\text { Marco António e } \\
\text { Cleópatra em Tarso }\end{array}$ & $1741-1755$ & $\begin{array}{l}\text { Vida de } \\
\text { António }\end{array}$ \\
\hline $\begin{array}{l}\text { NATOIRE, } \\
\text { CharlesJoseph }\end{array}$ & $\begin{array}{l}\text { O Banquete de } \\
\text { Cleópatra e Marco } \\
\text { António }\end{array}$ & 1754 & $\begin{array}{l}\text { Vida de } \\
\text { António }\end{array}$ \\
\hline $\begin{array}{l}\text { NATOIRE, } \\
\text { CharlesJoseph }\end{array}$ & $\begin{array}{l}\text { A chegada de } \\
\text { Cleópatra a Tarso }\end{array}$ & 1756 & $\begin{array}{l}\text { Vida de } \\
\text { António }\end{array}$ \\
\hline Negroni, Pietro & $\begin{array}{l}\text { O Sucidio de } \\
\text { Cleópatra }\end{array}$ & c. 1545 & $\begin{array}{l}\text { Vida de } \\
\text { António }\end{array}$ \\
\hline $\begin{array}{l}\text { Nouy, Jean } \\
\text { Lecomte du }\end{array}$ & $\begin{array}{l}\text { Demóstenes } \\
\text { praticando a oratória }\end{array}$ & 1870 & $\begin{array}{l}\text { Vida de } \\
\text { Alexandre (?) }\end{array}$ \\
\hline $\begin{array}{l}\text { ODEVAËRE, } \\
\text { JosephDenis }\end{array}$ & $\begin{array}{l}\text { A morte de Fócion ou } \\
\text { Catão }\end{array}$ & 1804 & $\begin{array}{l}\text { Vida de } \\
\text { Fócion } \\
\text { Vida de Catão } \\
\text { Menor }\end{array}$ \\
\hline Pauwel, Pieter & Rómulo e Remo & $1615-1616$ & $\begin{array}{l}\text { Vida de } \\
\text { Rómulo }\end{array}$ \\
\hline $\begin{array}{l}\text { Perugino, } \\
\text { Pietro }\end{array}$ & Catão & $1497-1500$ & $\begin{array}{l}\text { Vida de Catão } \\
\text { Menor }\end{array}$ \\
\hline $\begin{array}{l}\text { Piazzetta, } \\
\text { Giovanni } \\
\text { Battista }\end{array}$ & A Morte de Dario & c. 1746 & $\begin{array}{l}\text { Vida de } \\
\text { Alexandre }\end{array}$ \\
\hline Poussin, Nicolas & $\begin{array}{l}\text { O Rapto das } \\
\text { Mulheres Sabinas }\end{array}$ & $1634-1635$ & $\begin{array}{l}\text { Vida de } \\
\text { Rómulo }\end{array}$ \\
\hline Poussin, Nicolas & $\begin{array}{l}\text { O Rapto das } \\
\text { Mulheres Sabinas }\end{array}$ & $1637-1638$ & $\begin{array}{l}\text { Vida de } \\
\text { Rómulo }\end{array}$ \\
\hline Poussin, Nicolas & $\begin{array}{l}\text { Coriolano perante a } \\
\text { súplica de sua mãe }\end{array}$ & 1650 & $\begin{array}{l}\text { Vida de } \\
\text { Coriolano }\end{array}$ \\
\hline
\end{tabular}




\begin{tabular}{|c|c|c|c|}
\hline $\begin{array}{l}\text { Pujol, } \\
\text { Alexandre Denis } \\
\text { Abel de }\end{array}$ & A clemência de César & 1808 & $\begin{array}{l}\text { Vida de César } \\
\text { (?) }\end{array}$ \\
\hline $\begin{array}{l}\text { Pujol, } \\
\text { Alexandre Denis } \\
\text { Abel de }\end{array}$ & $\begin{array}{l}\text { Licurgo apresenta } \\
\text { aos Lacedemónios o } \\
\text { herdeiro do trono }\end{array}$ & 1811 & $\begin{array}{l}\text { Vida de } \\
\text { Licurgo }\end{array}$ \\
\hline $\begin{array}{l}\text { Pulgo, } \\
\text { Domenico }\end{array}$ & A Morte de Cleópatra & $\begin{array}{l}\text { Sécs. XV- } \\
\text { XVI }\end{array}$ & $\begin{array}{l}\text { Vida de } \\
\text { António }\end{array}$ \\
\hline $\begin{array}{l}\text { Regnault, } \\
\text { JeanBaptiste }\end{array}$ & $\begin{array}{l}\text { Diógenes visitado por } \\
\text { Alexandre }\end{array}$ & 1776 & $\begin{array}{l}\text { Vida de } \\
\text { Alexandre }\end{array}$ \\
\hline $\begin{array}{l}\text { RegnAULt, } \\
\text { JeanBaptiste }\end{array}$ & A Morte de Cleópatra & $\begin{array}{l}\text { c. } 1796- \\
1797 \\
\end{array}$ & $\begin{array}{l}\text { Vida de } \\
\text { António }\end{array}$ \\
\hline Reni, Guido & Cleópatra e a áspide & c. 1630 & $\begin{array}{l}\text { Vida de } \\
\text { António }\end{array}$ \\
\hline Reni, Guido & A Morte de Cleópatra & $1625-1626$ & $\begin{array}{l}\text { Vida de } \\
\text { António }\end{array}$ \\
\hline RenI, Guido & $\begin{array}{l}\text { O Suicídio de } \\
\text { Cleópatra }\end{array}$ & $1639-1640$ & $\begin{array}{l}\text { Vida de } \\
\text { António }\end{array}$ \\
\hline $\begin{array}{l}\text { RiccI, } \\
\text { Sebastiano }\end{array}$ & $\begin{array}{l}\text { Infância de Rómulo } \\
\text { e Remo ou Rómulo } \\
\text { em Remo em casa } \\
\text { de Faustulo e Aca } \\
\text { Larencia }\end{array}$ & c. 1708 & $\begin{array}{l}\text { Vida de } \\
\text { Rómulo }\end{array}$ \\
\hline Rivalz, Antoine & A Morte de Cleópatra & Séc. XVIII & $\begin{array}{l}\text { Vida de } \\
\text { António }\end{array}$ \\
\hline Rivalz, Antoine & Cleópatra & Séc. XVIII & $\begin{array}{l}\text { Vida de } \\
\text { António }\end{array}$ \\
\hline $\begin{array}{l}\text { Rixens, Jean } \\
\text { André }\end{array}$ & A Morte de Cleópatra & 1874 & $\begin{array}{l}\text { Vida de } \\
\text { António }\end{array}$ \\
\hline Robert, Hubert & $\begin{array}{l}\text { Capriccio de } \\
\text { Templo Romano. } \\
\text { Entrada Triunfal de } \\
\text { Alexandre, o Grande }\end{array}$ & $1755-1760$ & $\begin{array}{l}\text { Vida de } \\
\text { Alexandre }\end{array}$ \\
\hline
\end{tabular}




\begin{tabular}{|c|c|c|c|}
\hline Romano, Giulio & Imperador Alexandre & 1532 & $\begin{array}{l}\text { Vida de } \\
\text { Alexandre }\end{array}$ \\
\hline $\begin{array}{l}\text { Rotari, Pietro } \\
\text { Antonio }\end{array}$ & $\begin{array}{l}\text { Alexandre, o Grande } \\
\text { e Roxana perante o } \\
\text { túmulo de Aquiles }\end{array}$ & 1756 & $\begin{array}{l}\text { Vida de } \\
\text { Alexandre }\end{array}$ \\
\hline $\begin{array}{l}\text { Royer, Lionel- } \\
\text {-Nöel }\end{array}$ & $\begin{array}{l}\text { Vercingétorix rende-se } \\
\text { a César }\end{array}$ & 1899 & Vida de César \\
\hline $\begin{array}{l}\text { Rubens, Pieter } \\
\text { Paul }\end{array}$ & $\begin{array}{l}\text { Rómulo e Remo em } \\
\text { crianças }\end{array}$ & 1614 & $\begin{array}{l}\text { Vida de } \\
\text { Rómulo }\end{array}$ \\
\hline $\begin{array}{l}\text { Rubens, Pieter } \\
\text { Paul }\end{array}$ & Marte e Reia Silvia & $1616-1617$ & $\begin{array}{l}\text { Vida de } \\
\text { Rómulo }\end{array}$ \\
\hline $\begin{array}{l}\text { Rubens, Pieter } \\
\text { Paul }\end{array}$ & $\begin{array}{l}\text { Batalha das } \\
\text { Amazonas }\end{array}$ & 1618 & $\begin{array}{l}\text { Vida de Teseu } \\
\text { (?) }\end{array}$ \\
\hline $\begin{array}{l}\text { Rubens, Pieter } \\
\text { Paul }\end{array}$ & O Rapto das Sabinas & $1635-1637$ & $\begin{array}{l}\text { Vida de } \\
\text { Rómulo }\end{array}$ \\
\hline $\begin{array}{l}\text { SarTo, Andrea } \\
\text { del }\end{array}$ & O Triunfo de César & c. 1520 & Vida de César \\
\hline $\begin{array}{l}\text { SCHÖNFELD, } \\
\text { Johann Heinrich }\end{array}$ & $\begin{array}{l}\text { Alexandre, o Grande } \\
\text { perante o túmulo de } \\
\text { Aquiles }\end{array}$ & c. 1630 & $\begin{array}{l}\text { Vida de } \\
\text { Alexandre }\end{array}$ \\
\hline $\begin{array}{l}\text { SCHÖNFELD, } \\
\text { Johann Heinrich }\end{array}$ & $\begin{array}{l}\text { O Rapto das } \\
\text { Mulheres Sabinas }\end{array}$ & $1630-1650$ & $\begin{array}{l}\text { Vida de } \\
\text { Rómulo }\end{array}$ \\
\hline $\begin{array}{l}\text { SigNORELLI, } \\
\text { Luca }\end{array}$ & $\begin{array}{l}\text { Coriolano persuadido } \\
\text { pela sua familia a } \\
\text { poupar Roma }\end{array}$ & c. 1509 & $\begin{array}{l}\text { Vida de } \\
\text { Coriolano }\end{array}$ \\
\hline Sodомa II & $\begin{array}{l}\text { O Rapto das } \\
\text { Mulheres Sabinas }\end{array}$ & $1506-1507$ & $\begin{array}{l}\text { Vida de } \\
\text { Rómulo }\end{array}$ \\
\hline Sodoma II & $\begin{array}{l}\text { As mulheres da } \\
\text { familia de Dario } \\
\text { perante Alexandre, o } \\
\text { Grande }\end{array}$ & c. 1517 & $\begin{array}{l}\text { Vida de } \\
\text { Alexandre }\end{array}$ \\
\hline Sodoma II & $\begin{array}{l}\text { O Casamento de } \\
\text { Alexandre e Roxana }\end{array}$ & c. 1517 & $\begin{array}{l}\text { Vida de } \\
\text { Alexandre }\end{array}$ \\
\hline
\end{tabular}




\begin{tabular}{|c|c|c|c|}
\hline Steen, Jan & $\begin{array}{l}\text { O Banquete de } \\
\text { António e Cleópatra }\end{array}$ & $1668-1669$ & $\begin{array}{l}\text { Vida de } \\
\text { António }\end{array}$ \\
\hline $\begin{array}{l}\text { STOMER, } \\
\text { Matthias }\end{array}$ & A Morte de Catão & Séc. XVII & $\begin{array}{l}\text { Vida de Catão } \\
\text { Menor }\end{array}$ \\
\hline $\begin{array}{l}\text { STOMER, } \\
\text { Matthias }\end{array}$ & $\begin{array}{l}\text { Catão tirando a } \\
\text { venda }\end{array}$ & Séc. XVII & $\begin{array}{l}\text { Vida de Catão } \\
\text { Menor }\end{array}$ \\
\hline $\begin{array}{l}\text { STROzZI, } \\
\text { Bernardo }\end{array}$ & $\begin{array}{l}\text { Alexandre, o Grande } \\
\text { restaurando o } \\
\text { trono usurpado a } \\
\text { Abdolomino }\end{array}$ & Séc. XVI & $\begin{array}{l}\text { Vida de } \\
\text { Alexandre (?) }\end{array}$ \\
\hline $\begin{array}{l}\text { Tiepolo, } \\
\text { Giovanni } \\
\text { Battista }\end{array}$ & $\begin{array}{l}\text { Alexandre, o Grande } \\
\text { e Campaspe no } \\
\text { estúdio de Apeles }\end{array}$ & $1725-1726$ & $\begin{array}{l}\text { Vida de } \\
\text { Alexandre (?) }\end{array}$ \\
\hline $\begin{array}{l}\text { Tiepolo, } \\
\text { Giovanni } \\
\text { Battista } \\
\end{array}$ & $\begin{array}{l}\text { Alexandre, o Grande } \\
\text { e Campaspe no } \\
\text { estúdio de Apeles }\end{array}$ & 1740 & $\begin{array}{l}\text { Vida de } \\
\text { Alexandre }\end{array}$ \\
\hline $\begin{array}{l}\text { Tiepolo, } \\
\text { Giovanni } \\
\text { Battista }\end{array}$ & Coriolano & c. 1730 & $\begin{array}{l}\text { Vida de } \\
\text { Coriolano }\end{array}$ \\
\hline $\begin{array}{l}\text { Tiepolo, } \\
\text { Giovanni } \\
\text { Battista } \\
\end{array}$ & $\begin{array}{l}\text { A familia de Dario } \\
\text { perante Alexandre, o } \\
\text { Grande }\end{array}$ & 1743 & $\begin{array}{l}\text { Vida de } \\
\text { Alexandre }\end{array}$ \\
\hline $\begin{array}{l}\text { Tiepolo, } \\
\text { Giovanni } \\
\text { Battista }\end{array}$ & $\begin{array}{l}\text { O Banquete de } \\
\text { Cleópatra }\end{array}$ & $1743-1744$ & $\begin{array}{l}\text { Vida de } \\
\text { António }\end{array}$ \\
\hline $\begin{array}{l}\text { Tiepolo, } \\
\text { Giovanni } \\
\text { Battista } \\
\end{array}$ & $\begin{array}{l}\text { O Banquete de } \\
\text { Cleópatra }\end{array}$ & $1746-1747$ & $\begin{array}{l}\text { Vida de } \\
\text { António }\end{array}$ \\
\hline $\begin{array}{l}\text { Tiepolo, } \\
\text { Giovanni } \\
\text { Battista } \\
\end{array}$ & $\begin{array}{l}\text { O reencontro de } \\
\text { António e Cleópatra }\end{array}$ & $1746-1747$ & $\begin{array}{l}\text { Vida de } \\
\text { António }\end{array}$ \\
\hline $\begin{array}{l}\text { Tiepolo, } \\
\text { Giovanni } \\
\text { Battista }\end{array}$ & $\begin{array}{l}\text { Alexandre, o Grande } \\
\text { com a mulher de } \\
\text { Dario }\end{array}$ & $1750-1753$ & $\begin{array}{l}\text { Vida de } \\
\text { Alexandre }\end{array}$ \\
\hline
\end{tabular}




\begin{tabular}{|c|c|c|c|}
\hline Tintoretto & $\begin{array}{l}\text { A libertação de } \\
\text { Arsinoe }\end{array}$ & c. 1556 & $\begin{array}{l}\text { Vida de } \\
\text { Demétrio (?) }\end{array}$ \\
\hline $\begin{array}{l}\text { Tischbein, } \\
\text { Johann Heinrich } \\
\text { (o Antigo) }\end{array}$ & $\begin{array}{l}\text { António moribundo } \\
\text { junto de Cleópatra }\end{array}$ & $1767-1769$ & $\begin{array}{l}\text { Vida de } \\
\text { António }\end{array}$ \\
\hline $\begin{array}{l}\text { Tischbein, } \\
\text { Johann Heinrich } \\
\text { (o Antigo) }\end{array}$ & $\begin{array}{l}\text { Augusto à cabeceira } \\
\text { de Cleópatra } \\
\text { moribunda }\end{array}$ & 1769 & $\begin{array}{l}\text { Vida de } \\
\text { António }\end{array}$ \\
\hline $\begin{array}{l}\text { Tischbein, } \\
\text { Johann Heinrich } \\
\text { (o Antigo) }\end{array}$ & António e Cleópatra & 1774 & $\begin{array}{l}\text { Vida de } \\
\text { António }\end{array}$ \\
\hline $\begin{array}{l}\text { Topino- } \\
\text {-LeBrun, Jean- } \\
\text {-Baptiste }\end{array}$ & $\begin{array}{l}\text { A morte de Gaio } \\
\text { Graco }\end{array}$ & 1792 & $\begin{array}{l}\text { Vida de Gaio } \\
\text { Graco }\end{array}$ \\
\hline Uccello, Paolo & O Triunfo de César & Séc. XV & Vida de César \\
\hline $\begin{array}{l}\text { ULMANN, } \\
\text { Benjamin }\end{array}$ & $\begin{array}{l}\text { Coriolano em casa de } \\
\text { Tulo, rei dos Volscos }\end{array}$ & 1859 & $\begin{array}{l}\text { Vida de } \\
\text { Coriolano }\end{array}$ \\
\hline $\begin{array}{l}\text { Verona, } \\
\text { Michele de }\end{array}$ & $\begin{array}{l}\text { Coriolano persuadido } \\
\text { pela sua família a } \\
\text { poupar Roma }\end{array}$ & $1495-1510$ & $\begin{array}{l}\text { Vida de } \\
\text { Coriolano }\end{array}$ \\
\hline Veronese, Paolo & $\begin{array}{l}\text { A familia de Dario } \\
\text { perante Alexandre }\end{array}$ & $1565-1570$ & $\begin{array}{l}\text { Vida de } \\
\text { Alexandre }\end{array}$ \\
\hline $\begin{array}{l}\text { VerRochio, } \\
\text { Andrea del }\end{array}$ & A Batalha de Pidna & c. 1475 & $\begin{array}{l}\text { Vida de Paulo } \\
\text { Emílio }\end{array}$ \\
\hline VIGnon, Claude & A Morte de Cleópatra & Séc. XVII & $\begin{array}{l}\text { Vida de } \\
\text { António }\end{array}$ \\
\hline $\begin{array}{l}\text { Vleughels, } \\
\text { Nicolas }\end{array}$ & $\begin{array}{l}\text { Apeles pintando uma } \\
\text { paisagem }\end{array}$ & 1756 & $\begin{array}{l}\text { Vida de } \\
\text { Demétrio (?) } \\
\text { Vida de } \\
\text { Alexandre (?) }\end{array}$ \\
\hline Vos, Marten de & $\begin{array}{l}\text { O Tribunal de } \\
\text { Brabant Mint em } \\
\text { Antuérpia }\end{array}$ & 1594 & \\
\hline
\end{tabular}




\section{AneXo II}

\section{DisTRIBUIÇÁ̃O DAS PINTURAS \\ LEVANTADAS POR CENTÚRIAS}

\section{Século XV}

Fouquet, Jean, A fuga de Pompeio depois da batalha de Farsália, séc. XV.

FouQueT, Jean, César atravessando o Rubicão, séc. XV.

Uccello, Paolo, O Triunfo de César, séc. XV.

Luçon, Mestre de, Banquete de Cleópatra, iluminura do manuscrito de Boccaccio (ce), De casibus uirorum ilustrium, Des cas des nobles hommes et femmes, tradução francesa de Laurent de Premiierfait, vol. II, fol. 26, c. 1410 .

Luçon, Mestre de, A Morte de António e Cleópatra, iluminura do manuscrito de Boccaccio (ce), Des casibus virorum ilustrium, Des cas des nobles hommes et femmes, tradução francesa de Laurent de Premiierfait, vol. II, fol. 66, c. 1410.

Anónimo (Miniaturista flamengo), História de Alexandre, o Grande, 1450-1490.

Anónimo, A Morte de António e Cleópatra, iluminura do manuscrito de Boccaccio (ce), Des casibus virorum ilustrium, Des cas des nobles hommes et femmes, tradução francesa de Laurent de Premiierfait, vol. II, fol. 190v, 1460-1470. 
Foppa, Vicenzo, A leitura do menino Cícero, c. 1464.

Verrochio, Andrea del, A Batalha de Pidna, c. 1475.

Mantegna, Andrea, O Triunfo de César, dp. 1486.

Verona, Michele de, Coriolano persuadido pela sua família a poupar Roma, 1495-1510.

Botticelli, Sandro, A História de Lucrécia, 1496-1504.

Perugino, Pietro, Catão, 1497-1500.

Pulgo, Domenico, A Morte de Cleópatra, séc. XV-XVI.

\section{Século XVI}

Feselen, Melchior, Alésia cercada por Júlio César, séc. XVI.

Gengu, Girolamo, O filho de Fábio Máximo resgatando os prisioneiros de Anibal, séc. XVI.

Strozzi, Bernardo, Alexandre o Grande restaurando o trono usurpado a Abdolomino, séc. XVI.

Sodoma II, O Rapto das Mulheres Sabinas, 1506-1507.

Sodoma II, As mulheres da família de Dario perante Alexandre, o Grande, c. 1517.

Sodoma II, O Casamento de Alexandre e Roxana, c. 1517.

Signorelli, Luca, Coriolano persuadido pela sua familia a poupar Roma, c. 1509.

Beccafumi, Domenico, A morte de Catão, c. 1519.

SARTo, Andrea del, O Triunfo de César, c. 1520. 
JaCopo, Giovanni Battista (dito Il Rosso Fiorentino), A Morte de Cleópatra, 1524-1527.

Altdorfer, Albrecht, A Batalha de Alexandre, 1529.

Romano, Giulio, Imperador Alexandre, 1532.

Negroni, Pietro, O Sucídio de Cleópatra, c. 1545.

Brusasorci, Domenico, O Suicídio de Cleópatra, 1550-1555.

Ghirlandaio, Michele di Ridolfo del, O Suicídio de Cleópatra, c. 1560.

Veronese, Paolo, A familia de Dario perante Alexandre, 1565-1570.

Amalteo, Pomponio - A morte de Catão, c. 1580.

Anónimo (pintor activo em Veneza e Emília no final do século XVI), O Suicídio de Cleópatra, c. 1580 .

Fontana, Lavinia, Cleópatra, c. 1585.

Vos, Marten de, O Tribunal de Brabant Mint em Antuérpia, 1594.

\section{SÉculo XVII}

Anónimo (discip. Nicolas Poussin), Cleópatra e Octávio, séc. XVII.

Crayer, Gaspar de, Alexandre e Diógenes, séc. XVII.

Eecкоuт, Gerbrand von der, Volúmnia perante Coriolano, séc. XVII. 
Mignard, Pierre, A Morte de Cleópatra, séc. XVII. Stomer, Matthias, A Morte de Catão, séc. XVII. Stomer, Matthias, Catão tirando a venda, séc. XVII. Vignon, Claude, A Morte de Cleópatra, séc. XVII.

Cignaroli, Giambettino, A Morte de Catão, séc. XVII?

Brueghel, Jan (o velho), A Batalha de Isso, 1602.

Caravaggio, Os sete actos de misericórdia, 1607.

Rubens, Pieter Paul, Rómulo e Remo em crianças, 1614.

Domenichino, Timocleia cativa trazida perante Alexandre, c. 1615.

Pauwel, Pieter, Rómulo e Remo, 1615-1616.

Rubens, Pieter Paul, Marte e Reia Sílvia, 1616-1617.

Rubens, Pieter Paul, Batalha das Amazonas, 1618.

Gentileschi, Artemisa, Cleópatra, c. 1620.

Liss, Johann, A Morte de Cleópatra, 1622-1624.

Honthorst, Gerrit von, Solón e Creso, 1624.

Reni, Guido, A Morte de Cleópatra, 1625-1626.

Cortona, Pietro de, O Rapto das Mulheres Sabinas, 1627-1629.

Blanchard, Marte e a Vestal Virginia, c. 1630.

Reni, Guido, Cleópatra e a áspide, c. 1630.

Schönfeld, Johann Heinrich, Alexandre, o Grande perante o túmulo de Aquiles, c. 1630. 
Schönfeld, Johann Heinrich, O Rapto das Mulheres Sabinas, 1630-1650.

Poussin, Nicolas, O Rapto das Mulheres Sabinas, 1634-1635.

Rubens, Pieter Paul, O Rapto das Sabinas, 1635-1637.

Poussin, Nicolas, O Rapto das Mulheres Sabinas, 1637-1638.

Hire, Laurent de La, Teseu e Aetra, 1635-1640.

Assereto, Gioacchino, O suicídio de Catão, c. 1639.

Reni, Guido, O Suicídio de Cleópatra, 1639-1640.

Barbieri, Giovanni Francesco (dito Le Guerchin), Cleópatra perante Octávio Augusto, c. 1640.

Gellée, Claude (dito Le Lorrain), O desembarque de Cleópatra em Tarso ou Páris e Helena desembarcando em Tróia, 1642.

Cortona, Pietro de, Rómulo e Remo acolhidos por Fáustulo, c. 1643.

Bourdon, Sébastien, $O$ reencontro de António e Cleópatra, c. 1645.

Guercino, Hersilia separando Rómulo de Tácio, 1645.

Hire, Laurent de La, Cornélia recusa a coroa de Ptolomeu, 1646.

Ferrari, Luca, A Morte de Cleópatra, c. 1650.

Langetti, Giovanni Battista, Diógenes e Alexandre, c. 1650 . 
Poussin, Nicolas, Coriolano perante a súplica de sua mãe, 1650.

Jordaens, Jacob, A Morte de Cleópatra, 1653.

Cagnacci, Guido, Cleópatra, c. 1659.

Cagnacci, Guido, A Morte de Cleópatra, c. 1659/1661-1662.

Le Brun, Charles, A familia de Dario perante Alexandre, c. 1660.

Mazzoni, Sebastiano, A Morte de Cleópatra, 1660.

Everdingen, Caesar von, Licurgo demonstrando os benefícios da Educação, 1660-1662.

Langetti, Giovanni Battista, Catão, 1660-1680.

АввіAті, Filippo, Coriolano persuadido pela sua família a poupar Roma, 1661.

Le Brun, Charles, Entrada de Alexandre em Babilónia, c. 1664 .

Le Brun, Charles, Alexandre e Poro, 1665.

Steen, Jan, O Banquete de António e Cleópatra, 1668-1669.

Cozza, Francesco, Cleópatra oferecendo-se à morte, 1675.

LAIresse, Gérard de, O banquete de Cleópatra, c. 1675.

LAIRESSE, Gérard de, A Morte de Cleópatra, 1675-1680.

Lairesse, Gérard de, $O$ desembarque de Cleópatra em Tarso ou Páris e Helena desembarcando em Tróia, 1685-1690. 
Balestra, Antonio, Teseu descobre a espada de seu pai, séc. XVII-XVIII.

\section{Século XVIII}

Diziani, Gaspare, A familia de Dario perante Alexandre, o Grande, séc. XVIII.

Gauffier, Louis, Rómulo em Remo em casa de Fáustulo e Aca Larência, séc. XVIII.

Gravelot, Hubert François, Augusto e Cleópatra, séc. XVIII.

Hoet, Gérard, A Morte de Cleópatra, séc. XVIII.

Rivalz, Antoine, A Morte de Cleópatra, séc. XVIII.

Rivalz, Antoine, Cleópatra, séc. XVIII.

Ricci, Sebastiano, Infância de Rómulo e Remo ou Rómulo em Remo em casa de Faustulo e Aca Larencia, c. 1708.

Biscaino, Bartolomeo, Coriolano recebendo as matronas romanas, c. 1725 .

Tiepolo, Giovanni Battista, Alexandre, o Grande e Campaspe no estúdio de Apeles, 1725-1726.

Tiepolo, Giovanni Battista, Coriolano, c. 1730.

Tiepolo, Giovanni Battista, Alexandre, o Grande e Campaspe no estúdio de Apeles, 1740.

Tiepolo, Giovanni Battista, A família de Dario perante Alexandre, $O$ Grande, 1743.

Tiepolo, Giovanni Battista, O Banquete de Cleópatra, 1743-1744. 
Tiepolo, Giovanni Battista, O Banquete de Cleópatra, 1746-1747.

Tiepolo, Giovanni Battista, O reencontro de António e Cleópatra, 1746-1747.

Tiepolo, Giovanni Battista, Alexandre, o Grande com a mulher de Dario, 1750-1753.

Vleughels, Nicolas, Apeles pintando uma paisagem, 1756.

Tischbein, Johann Heinrich (o Antigo), António moribundo junto de Cleópatra, 1767-1769.

Tischbein, Johann Heinrich (o Antigo), Augusto à cabeceira de Cleópatra moribunda, 1769.

Tischbein, Johann Heinrich (o Antigo), António e Cleópatra, 1774.

Conca, Sebastiano, Alexandre, o Grande no Templo de Jerusalém, 1735-1737.

Tiepolo, Giovanni Battista, Alexandre, o Grande e Campasge no estúdio de Apeles, 1740.

Tischbein, Johann Heinrich (o Antigo), António moribundo junto de Cleópatra, 1767-1769.

Tischbein, Johann Heinrich (o Antigo), Augusto à cabeceira de Cleópatra moribunda, 1769.

Natolre, Charles-Joseph, O reencontro de Marco António e Cleópatra em Tarso, 1741-1755.

Tiepolo, Giovanni Battista, A família de Dario perante Alexandre, O Grande, 1743. 
Tiepolo, Giovanni Battista, O Banquete de Cleópatra, 1743-1744.

Piazzetta, Giovanni Battista, A Morte de Dario, c. 1746.

Tiepolo, Giovanni Battista, O Banquete de Cleópatra, 1746-1747.

Tiepolo, Giovanni Battista, O reencontro de António e Cleópatra, 1746-1747.

Tiepolo, Giovanni Battista, Alexandre, o Grande com a mulher de Dario, 1750-1753.

Natoire, Charles-Joseph, O Banquete de Cleópatra e Marco António, 1754.

Robert, Hubert, Capriccio de Templo Romano. Entrada Triunfal de Alexandre, o Grande, 1755-1760.

Rotari, Pietro Antonio, Alexandre, o Grande $e$ Roxana perante o túmulo de Aquiles, 1756

Natoire, Charles-Joseph, A chegada de Cleópatra a Tarso, 1756.

Vleughels, Nicolas, Apeles pintando uma paisagem, 1756.

Mengs, Anton Raphael, Augusto e Cleópatra, 1759.

Mengs, Anton Raphael, Augusto e Cleópatra, 1760.

Batoni, Pompeo, A Morte de Marco António, 1763.

Hamilton, Gavin, O Juramento de Brutus, 1763-1764.

Hamilton, Gavin, Cleópatra, 1767-1769.

Kauffmann, Angelika, Cleópatra decorando o túmulo de Marco António, 1769-1770. 
Beaufort, Jacques-Antoine, O Juramento de Brutus, 1771.

David, Jacques-Louis, Antioco e Estratonice, 1774.

Tischbein, Johann Heinrich (o Antigo), António e Cleópatra, 1774.

Regnault, Jean-Baptiste, Diógenes visitado por Alexandre, 1776.

Hallé, Noël, Cornélia mãe dos Gracos, 1779.

Lacour, Pierre, Cleópatra lamentando-se no túmulo de Marco António, 1781.

Ménageot, François Guillaume, Cleópatra no túmulo de Marco António, 1785.

Gauffier, Louis, Entrevista de Augusto e Cleópatra depois da batalha de Áccio, 1788.

DAvid, Jacques -Louis, Os lictores devolvendo a Brutus os corpos de seus filhos, 1789.

Duvivier, Johannes Bernardus, Cleópatra capturada pelos soldados romanos após a morte de Marco António, 1789.

Cades, Giuseppe, Alexandre, o Grande recusa beber água, 1792

Topino-Lebrun, Jean-Baptiste, A morte de Gaio Graco, 1792.

LeTHIÈRE, Guillaume, A morte de Catão em Útica, 1795.

Regnault, Jean-Baptiste, A Morte de Cleópatra, c. $1796-1797$ 
Bouchet, Louis-André-Gabriel, A morte de Catão de Útica, 1797.

Bouillon, Pierre, A morte de Catão de Útica, 1797.

GuÉrin, Pierre-Narcisse, A morte de Catão de Útica, 1797.

David, Jacques-Louis, A Intervenção das Mulheres Sabinas, 1799.

\section{SÉculo XIX}

Guérin, Pierre-Narcisse, O Casamento de Alexandre, $o$ Grande e Roxana, séc. XIX.

Camuccini, Vincenzo, Os Idos de Março / A morte de César, c. 1800.

Camuccini, Vincenzo, O Triunfo de César, c. 1800.

Camuccini, Vincenzo, Rómulo e Remo descobertos, c. 1800.

Odevaëre, Joseph-Denis, $A$ morte de Fócion, 1804 (Catão).

Boisselier, Félix, A Morte de Demóstenes, 1805.

Heim, François-Joseph, Teseu vencedor do Minotauro, 1807.

Pujol, Alexandre Denis Abel de, A clemência de César, 1808.

Pujol, Alexandre Denis Abel de, Licurgo apresenta aos Lacedemónios o herdeiro do trono, 1811.

Boisfremont, Charles-Pompée le Boulanger de, $A$ 
Morte de Cleópatra, 1824-1828.

Dupré, François-Xavier, Coriolano na casa de Tulo, rei dos Volscos, 1827.

Bracassat, Jacques-Raymond, Coriolano e sua mãe, 1831.

Flandrin, Hippolyte, Teseu reconhecido por seu pai, 1832.

Delacroix, Eugène, Cleópatra e o Camponês, 1838.

Brisset, Pierre-Nicolas, A Partida de Gaio Graco, 1840.

Ingres, Jean-Auguste, Antíoco e Estratonice, 1840.

Ulmann, Benjamin, Coriolano em casa de Tulo, rei dos Volscos, 1859.

Dejussieu, Henri Blaise François, Cleópatra ou Cleópatra e a escrava, 1863.

Hillemacher, Eugéne Ernest, António moribundo levado até Cleópatra, 1863.

Gérôme, Jean-Léon, A Morte de César, 1867.

Nouy, Jean Lecomte du, Demóstenes praticando a oratória, 1870.

Giannetti, Raffaele, O último senado de Júlio César, 1867.

Böcklin, Arnold, A Morte de Cleópatra, 1872.

Rixens, Jean André, A Morte de Cleópatra, 1874.

Makart, Hans, A Morte de Cleópatra, 1875.

Böcklin, Arnold, A Morte de Cleópatra, 1878. 
Alma-Tadema, Sir Lawrence, $O$ reencontro de António e Cleópatra, 41 a.C., 1883.

Moreau, Gustave, O Triunfo de Alexandre, o Grande, c. 1885 .

Cabanel, Alexandre, Cleópatra ensaiando os venenos nos condenados à morte, 1887.

Collier, John, A Morte de Cleópatra, 1890.

Royer, Lionel-Nöel, Vercingétorix rende-se a César, 1899. 


\section{AneXo III}

\section{LISTAGEM DAS OBRAS POR PERSONAGENS MAIS REPRESENTADAS}

\section{Rómulo e Remo}

Blanchard, Marte e a Vestal Virginia, c. 1630.

Rubens, Pieter Paul, Marte e Reia Sílvia, 1616-1617.

Camuccini, Vincenzo, Rómulo e Remo descobertos, c. 1800 .

Pauwel, Pieter, Rómulo e Remo, 1615-1616.

Cortona, Pietro de, Rómulo e Remo acolhidos por Fáustulo, c. 1643.

Gauffier, Louis, Rómulo em Remo em casa de Fáustulo e Aca Larência, séc. XVIII.

Ricci, Sebastiano, Infância de Rómulo e Remo ou Rómulo em Remo em casa de Fáustulo e Aca Larencia, c. 1708 .

Rubens, Pieter Paul, Rómulo e Remo em crianças, 1614.

Cortona, Pietro de, O Rapto das Mulheres Sabinas, 1627-1629.

Poussin, Nicolas, O Rapto das Mulheres Sabinas, 1634-1635.

Poussin, Nicolas, O Rapto das Mulheres Sabinas, 1637-1638.

Rubens, Pieter Paul, $O$ Rapto das Sabinas, 1635-1637. 
Schönfeld, Johann Heinrich, O Rapto das Mulheres Sabinas, 16301650.

Sodoma II, O Rapto das Mulheres Sabinas, 1506-1507.

David, Jacques-Louis, A Intervenção das Mulheres Sabinas, 1799.

Guercino, Hersília separando Rómulo de Tácio, 1645.

\section{Coriolano}

Dupré, François-Xavier, Coriolano na casa de Tulo, rei dos Volscos, 1827.

Ulmann, Benjamin, Coriolano em casa de Tulo, rei dos Volscos, 1859.

Аввінті, Filippo, Coriolano persuadido pela sua família a poupar Roma, 1661.

Biscaino, Bartolomeo, Coriolano recebendo as matronas romanas, c. 1725.

Brascassat, Jacques-Raymond, Coriolano e sua mäe, 1831.

Eecкоuт, Gerbrand von der, Volúmnia perante Coriolano, séc. XVII.

Poussin, Nicolas, Coriolano perante a súplica de sua mãe, 1650.

Signorelli, Luca, Coriolano persuadido pela sua familia a poupar Roma, c. 1509.

Tiepolo, Giovanni Battista, Coriolano, c. 1730. 
Verona, Michele de, Coriolano persuadido pela sua família a poupar Roma, 1495-1510.

\section{JÚlIO CÉSAR}

Camuccini, Vincenzo, O Triunfo de César, c. 1800.

Mantegna, Andrea, O Triunfo de César, dp. 1486.

SARto, Andrea del, O Triunfo de César, c. 1520.

Uccello, Paolo, O Triunfo de César, séc. XV.

Fouquet, Jean, A fuga de Pompeio depois da batalha de Farsália, séc. XV.

FouQuet, Jean, César atravessando o Rubicão, séc. XV.

Feselen, Melchior, Alésia cercada por Júlio César, séc. XVI.

Royer, Lionel-Nöel, Vercingétorix rende-se a César, 1899.

Pujol, Alexandre Denis Abel de, A clemência de César, 1808.

Giannetti, Raffaele, O último senado de Júlio César, 1867.

Camuccini, Vincenzo, Os Idos de Março / A morte de César, c. 1800

Gérôme, Jean-Léon, A Morte de César, 1867.

\section{Catáo}

OdevaËre, Joseph-Denis, A morte de Fócion, 1804 (Catão). 
Stomer, Matthias, Catão tirando a venda, séc. XVII. Amalteo, Pomponio, A morte de Catão, c. 1580. Assereto, Gioacchino, O suícidio de Catão, c. 1639. Beccafumi, Domenico, A morte de Catão, c. 1519. Bouchet, Louis-André-Gabriel, A morte de Catão de Útica, 1797.

Boulllon, Pierre, A morte de Catão de Útica, 1797.

Cignaroli, Giambettino, A Morte de Catão, séc. XVII?

GuÉRIn, Pierre-Narcisse, A morte de Catão de Útica, 1797.

Langetti, Giovanni Battista, Catão, 1660-1680.

Lethière, Guillaume, A morte de Catão em Útica, 1795.

Perugino, Pietro, Catão, 1497-1500.

Stomer, Matthias, A Morte de Catão, séc. XVII

\section{AleXandre}

Romano, Giulio, Imperador Alexandre, 1532.

Moreau, Gustave, O Triunfo de Alexandre, o Grande, c. 1885 .

Robert, Hubert, Capriccio de Templo Romano. Entrada Triunfal de Alexandre, o Grande, 1755-1760.

Altdorfer, Albrecht, A Batalha de Alexandre, 1529.

Brueghel, Jan (o velho), A Batalha de Isso, 1602. 
Anónimo (Miniaturista flamengo), História de Alexandre, o Grande, 14501490.

Conca, Sebastiano, Alexandre, o Grande no Templo de Jerusalém, 17351737.

Strozzi, Bernardo, Alexandre o Grande restaurando o trono usurpado a Abdolomino, séc. XVI.

Piazzetta, Giovanni Battista, A Morte de Dario, c. 1746 .

Diziani, Gaspare, A familia de Dario perante Alexandre, o Grande, séc. XVIII.

Le Brun, Charles, A familia de Dario perante Alexandre, c. 1660.

Sodoma II, As mulheres da familia de Dario perante Alexandre, o Grande, c. 1517.

Tiepolo, Giovanni Battista, A família de Dario perante Alexandre, $O$ Grande, 1743.

Tiepolo, Giovanni Battista, Alexandre, o Grande com a mulher de Dario, 1750-1753.

Veronese, Paolo, A família de Dario perante Alexandre, 1565-1570.

Le Brun, Charles, Entrada de Alexandre em Babilónia, c. 1664 .

Tiepolo, Giovanni Battista, Alexandre, o Grande e Campaspe no estúdio de Apeles, 1725-1726.

Tiepolo, Giovanni Battista, Alexandre, o Grande e Campaspe no estúdio de Apeles, 1740. 
Vleughels, Nicolas, Apeles pintando uma paisagem, 1756.

Domenichino, Timocleia cativa trazida perante Alexandre, c. 1615.

Crayer, Gaspar de, Alexandre e Diógenes, séc. XVII.

Langetti, Giovanni Battista, Diógenes e Alexandre, c. 1650 .

Regnault, Jean-Baptiste, Diógenes visitado por Alexandre, 1776.

Le Brun, Charles, Alexandre e Poro, 1665.

GuÉrin, Pierre-Narcisse, O Casamento de Alexandre, o Grande e Roxana, séc. XIX.

Sodoma II, O Casamento de Alexandre e Roxana, c. 1517.

Rotari, Pietro Antonio, Alexandre, o Grande $e$ Roxana perante o túmulo de Aquiles, 1756.

Schönfeld, Johann Heinrich, Alexandre, o Grande perante o túmulo de Aquiles, c. 1630.

Cades, Giuseppe, Alexandre, o Grande recusa beber água, 1792

\section{Cleópatra}

Tintoretto, A libertação de Arsinoe, c. 1556.

Lairesse, Gérard de, O desembarque de Cleópatra em Tarso ou Páris e Helena desembarcando em Tróia, 1685-1690. 
Alma-Tadema, Sir Lawrence, O reencontro de António e Cleópatra, 41 a.C., 1883.

Bourdon, Sébastien, $O$ reencontro de António e Cleópatra, c. 1645.

Gellée, Claude (dito Le Lorrain), O desembarque de Cleópatra em Tarso ou Páris e Helena desembarcando em Tróia, 1642.

Natoire, Charles-Joseph, O reencontro de Marco António e Cleópatra em Tarso, 1741-1755.

Natoire, Charles-Joseph, A chegada de Cleópatra a Tarso, 1756

Tiepolo, Giovanni Battista, O reencontro de António e Cleópatra, 17461747.

Tischbein, Johann Heinrich (o Antigo), António e Cleópatra, 1774.

LaIresse, Gérard de, O banquete de Cleópatra, c. 1675.

Luçon, Mestre de, Banquete de Cleópatra, iluminura do manuscrito de Boccaccio (ce), Des casibus virorum ilustrium, Des cas des nobles hommes et femmes, tradução francesa de Laurent de Premiierfait, vol. II, fol. 26, c. 1410.

Natoire, Charles-Joseph, O Banquete de Cleópatra e Marco António, 1754.

Steen, Jan, O Banquete de António e Cleópatra, 1668-1669.

Tiepolo, Giovanni Battista, O Banquete de Cleópatra, 1743-1744.

Tiepolo, Giovanni Battista, O Banquete de Cleópatra, 
$1746-1747$.

Cabanel, Alexandre, Cleópatra ensaiando os venenos nos condenados à morte, 1887.

Dejussieu, Henri Blaise François, Cleóatra ou Cleópatra e a escrava, 1863.

Delacroix, Eugène, Cleópatra e o Camponês, 1838.

Hillemacher, Eugéne Ernest, António moribundo levado até Cleópatra, 1863.

Tischbein, Johann Heinrich (o Antigo), António moribundo junto de Cleópatra, 1767-1769.

Anónimo, A Morte de António e Cleópatra, iluminura do manuscrito de Boccaccio (ce), Des casibus virorum ilustrium, Des cas des nobles hommes et femmes, tradução francesa de Laurent de Premiierfait, vol. II, fol. 190v, 1460-1470.

Luçon, Mestre de, A Morte de António e Cleópatra, iluminura do manuscrito de Boccacio (ce), Des casibus virorum ilustrium, Des cas des nobles hommes et femmes, tradução francesa de Laurent de Premiierfait, vol. II, fol. 66, c. 1410.

Batoni, Pompeo, A Morte de Marco António, 1763.

Kauffmann, Angelika, Cleópatra decorando o túmulo de Marco António, 1769-1770.

Ménageot, François Guillaume, Cleópatra no túmulo de Marco António, 1785.

Lacour, Pierre, Cleópatra lamentando-se no túmulo de Marco António, 1781. 
Duvivier, Johannes Bernardus, Cleópatra capturada pelos soldados romanos após a morte de Marco António, 1789.

Anónimo (discip. Nicolas Poussin), Cleópatra e Octávio, séc. XVII.

Barbieri, Giovanni Francesco (dito Le Guerchin), Cleópatra perante Octávio Augusto, c. 1640.

Gauffier, Louis, Entrevista de Augusto e Cleópatra depois da batalha de Accio, 1788.

Gravelot, Hubert François, Augusto e Cleópatra, séc. XVIII

Mengs, Anton Raphael, Augusto e Cleópatra, 1759.

Mengs, Anton Raphael, Augusto e Cleópatra, 1760.

Anónimo (pintor activo em Veneza e Emília no final do século XVI), O Suicídio de Cleópatra, c. 1580 .

Böcklin, Arnold, A Morte de Cleópatra, 1872.

Böcklin, Arnold, A Morte de Cleópatra, 1878.

Boisfremont, Charles-Pompée le Boulanger de, $A$ Morte de Cleópatra, 1824-1828.

Brusasorci, Domenico, O Suicídio de Cleópatra, 1550-1555.

Cagnacci, Guido, Cleópatra, c. 1659.

Cagnacci, Guido, A Morte de Cleópatra, c. 1659/ 1661-1662.

Collier, John, A Morte de Cleópatra, 1890. 
Cozza, Francesco, Cleópatra oferecendo-se à morte, 1675.

Ferrari, Luca, A Morte de Cleópatra, c. 1650.

Fontana, Lavinia, Cleópatra, c. 1585.

Gentileschi, Artemisa, Cleópatra, c. 1620.

Ghirlandaio, Michele di Ridolfo del, O Suicídio de Cleópatra, c. 1560.

Hamilton, Gavin, Cleópatra, 1767-1769.

Hoet, Gérard, A Morte de Cleópatra, séc. XVIII.

JaCopo, Giovanni Battista (dito Il Rosso Fiorentino), A Morte de Cleópatra, 1524-1527.

Jordaens, Jacob, A Morte de Cleópatra, 1653.

LaIresse, Gérard de, A Morte de Cleópatra, 1675-1680.

Liss, Johann, A Morte de Cleópatra, 1622-1624.

Makart, Hans, A Morte de Cleópatra, 1875.

Mazzoni, Sebastiano, A Morte de Cleópatra, 1660.

Mignard, Pierre, A Morte de Cleópatra, séc. XVII.

Negroni, Pietro, O Sucídio de Cleópatra, c. 1545.

Pulgo, Domenico, A Morte de Cleópatra, séc. XV-XVI.

Regnault, Jean-Baptiste, A Morte de Cleópatra, c. 1796-1797.

Reni, Guido, Cleópatra e a áspide, c. 1630.

Reni, Guido, A Morte de Cleópatra, 1625-1626.

Reni, Guido, O Suicídio de Cleópatra, 1639-1640. 
Rivalz, Antoine, A Morte de Cleópatra, séc. XVIII.

Rivalz, Antoine, Cleópatra, séc. XVIII.

Rixens, Jean André, A Morte de Cleópatra, 1874.

Vignon, Claude, A Morte de Cleópatra, séc. XVII.

Tischbein, Johann Heinrich (o Antigo), Augusto à cabeceira de Cleópatra moribunda, 1769. 


\section{LEAST THAT'S WHAT PLUTARCH SAYS Plutarco No Cinema}

Nuno Simóes Rodrigues 
(Página deixada propositadamente em branco) 


\section{LEAST THAT'S WHAT PLUTARCH SAYS}

\section{Plutarco no cinema}

Nuno Simóes Rodrigues

(Universidade de Lisboa)

No momento em que escrevemos este texto, lemos duas notícias pertinentes para o tema que aqui propomos tratar. A primeira é a de que o actor inglês Ralph Fiennes iniciou as filmagens de mais uma adaptação da obra de Shakespeare ao cinema. Desta vez trata-se de Coriolanus, protagonizado pelo próprio Fiennes, no papel titular, o qual é secundado por Gerard Butler (Aufídio), Vanessa Redgrave (Volúmnia), Brian Cox (Menénio) e Jessica Chastain (Vergília). Escrita muito provavelmente entre 1605 e 1610, o Coriolanus de Shakespeare pertence ao grupo das chamadas "peças romanas», uma das últimas a ter sido escrita, baseando-se na vida plutarquiana com o mesmo título ${ }^{1}$. A sua apresentação no grande ecrã corresponderá, portanto, a mais uma presença de Plutarco na Sétima Arte, ainda que por via indirecta. Mas lemos igualmente a notícia de que Angelina Jolie será a próxima actriz a encarnar Cleópatra VII no cinema, num novo filme do género biopics, que estreará em breve. Como é evidente, Plutarco deverá estar de novo na base desta reprise da vida da última rainha do Egipto.

${ }^{1}$ Ver a introdução de Parker (1982) 1-148. Ao mesmo grupo de peças pertencem naturalmente Julius Caesar e Antony and Cleopatra. A adaptação dirigida por Ralph Fiennes deverá estrear ainda em 2010. 
O recurso não é novo. Em alguns casos, foi mesmo sofisticado e pouco evidente. Mas é Plutarco quem motiva o enredo central ou parte dele em vários filmes ou adaptaçôes da História do Cinema. Em Seven Brides for Seven Brothers, comédia musical originalmente escrita para cinema e estreada em 1954, pela mão de Stanley Donen, a personagem principal canta uma canção escrita por Johnny Mercer, que começa com a seguinte estrofe:

Tell ya 'bout them Sobbin' women

Who lived in the Roman days.

It seems that they all went swimmin'

While their men was off to graze.

Well, a Roman troop was ridin' by

And saw them in their «me oh my»,

So they took 'em all back home to dry.

Least that's what Plutarch says.

Adam Pontipee (Howard Keel), assim se chama a personagem, canta para os seus irmãos, tendo na mão o livro que lhes acaba de ler e que é uma edição das Vidas de Plutarco. É para esse livro que aponta, quando afirma «Least that's what Plutarch says». O enredo deste musical, posteriormente adaptado ao teatro, baseava-se num conto de Stephen Vincent Benét, The Sobbin' Women, que por sua vez é uma adaptação da antiga lenda romana «O rapto das Sabinas» ${ }^{2}$. A história, porém,

${ }^{2}$ Seven Brides for Seven Brothers foi nomeado para o Óscar de melhor filme em 1954. O filme foi realizado por Stanley Donen, com música de Saul Chaplin e Gene de Paul e letras de Johnny 
passa-se agora em meados do século XIX, no Oregon, o West norte-americano, onde sete irmãos procuram desesperadamente sete noivas com quem se casar. Seis deles raptam as suas. A base do argumento é sem dúvida o episódio narrado por Plutarco na Vida de Rómulo ${ }^{3}$. Estamos portanto perante o caso de uma influência clássica num projecto cinematográfico, em que o motivo central apenas se torna perceptível a quem tiver uma formação que lho permita. Este artifício, todavia, ainda que presente em algumas produçóes, não tem sido a norma no que diz respeito ao aproveitamento da obra de Plutarco por parte da indústria cinematográfica. Efectivamente, a maioria da recepção tem-se feito de uma forma quase directa, como veremos se seguida.

Plutarco deverá ser uma das autoridades que mais inspirou obras de arte na cultura ocidental, do romance à tragédia, da ópera à pintura ${ }^{4}$. A estas formas de arte, podemos acrescentar o cinema. O que verificamos é que assim como a obra do Queronense havia constituído um importante manancial de informação histórica e de inspiração para a Europa culta desde pelo menos o Renascimento, também o cinema se aproveitou dos argumentos e "guiôes» pré-feitos pelo tratadista

Mercer. Howard Keel e Jane Powell foram os protagonistas. A base plutarquiana deste argumento foi tratada por Martín Rodríguez (2007).

${ }^{3}$ Plutarco, Rómulo 14-20.

${ }^{4}$ Petrovic (2008) 163; sobre Plutarco na pintura, vide o texto de P. S. Rodrigues neste mesmo volume; em relação à influência de Plutarco no caso concreto da cultura norte-americana moderna e contemporânea, ver Malamud (2009) 29; Winkler (2001a) 50; Solomon (2001) 322. 
grego e, em grande parte, reciclou-os, reutilizou-os e pô-los ao seu serviço 5 . Como foi já notado, Plutarco é provavelmente um dos autores mais presentes nos argumentos cinematográficos baseados na Antiguidade, ainda que raramente ele seja explicitado nos créditos de cada uma das produçóes em que está envolvido ${ }^{6}$. Parte considerável da transposição de Plutarco para a Sétima Arte assenta nas Vidas, mas não exclusivamente. A influência faz-se notar não só nos chamados «épicos» como em outros filmes comummente conhecidos como pepla ${ }^{7}$. Em todos eles surgem construçóes e leituras modernas de figuras como Temístocles, Leónidas, Alexandre, Rómulo, Coriolano, Pompeio, Espártaco, Bruto, Júlio César, António e Cleópatra e ainda algumas figuras do período imperial romano, como Otáo. Todos estes marcam presença na Sétima Arte e todos eles, sem excepção, reviveram no cinema graças à obra de Plutarco.

Nas páginas que se seguem, propomos uma leitura não exaustiva da recepçáo de Plutarco no cinema, oferecendo uma perspectiva geral das produçóes

${ }^{5}$ Como indica Martín Rodríguez (2007) 633, o nosso autor pode ter inspirado de igual modo, com a evocação da espada de Dâmocles e dos espelhos de Arquimedes, os sábios que escapam, graças à aplicaçáo dos recursos destas anedotas, ao seu sequestro por um gangster na comédia de Howard Hawks Ball of Fire (1941). Agradecemos esta nota ao Doutor A. Pérez Jiménez. Sobre as referências plutarquianas acerca de Arquimedes, ver Plutarco, Marcelo 15-20. Sobre Dâmocles, ver Cícero, Tusculanas 21.61-62.

${ }^{6}$ Como refere Petrovic (2008) 163, a excepção honrosa cabe a Mankiewicz que nos créditos de Cleopatra (1963) coloca lado a lado Plutarco, Suetónio e Apiano.

7 Sobre este género de cinema escreveremos infra. 
baseadas total ou parcialmente na sua obra e até hoje levadas ao ecrã. Analisamos os casos mais significativos dessas reinvençóes contemporâneas do Queronense e assinalamos algumas das problemáticas consideradas mais pertinentes neste contexto. Em suma, propomos uma introdução a um tema que, a nosso ver, merece ainda estudos mais aprofundados.

Por uma questão metodológica, começamos com os Gregos e seguem-se os Romanos, na linha do que acontece com a maioria das uitae escritas pelo próprio Plutarco. Pontualmente, fazemos referência a outras fontes, passos ou influências ${ }^{8}$.

\section{Temístocles e Leónidas}

Temístocles, a quem Plutarco dedicou uma biografia, é uma das personagens do filme de Rudolph Maté, The 300 Spartans, produzido pela Fox em 1961. $\mathrm{O}$ argumento desta película gira em torno da Batalha das Termópilas, ocorrida em 480 a.C., entre Gregos, representados pelos Espartanos e pelos Téspios, e Persas, quando Xerxes atacou a Hélade. Rodado na Grécia, o filme é reconhecido como uma apologia da História grega antiga e moderna, em que o espírito de uniáo entre Espartanos e Atenienses serve também de metáfora às realidades políticas que então se viviam na região. Aqueles que defendem a unidade e o pan-helenismo

${ }^{8}$ Nesta apresentação, usamos primeiro um critério civilizacional (os Gregos precedem os Romanos) e, dentro do civilizacional, o cronológico, ainda que tenhamos em conta a ressalva de que figuras como Rómulo e Coriolano não são necessariamente "históricas", mas sobretudo mitológico-lendárias. 
surgem como caracteres positivos, enquanto o oposto é igualmente válido.

Os representantes da união são Temístocles (Ralph Richardson), do lado ateniense, e Leónidas (Richard Egan), da facção espartana. $\mathrm{O}$ primeiro representa o político por excelência e o segundo é o soldado que está disposto a dar a vida por aquilo em que acredita. Juntos, representam a inteligência e a força ${ }^{9}$. Não deverá ser inocente que, em plena Guerra Fria, as duas personagens sejam interpretadas por dois actores anglófonos, mas em que um é britânico e o outro norteamericano. $\mathrm{O}$ paralelo com a realidade antiga parece-nos evidente. Por sua vez, Xerxes (David Farrar) representa o oriente bárbaro cujos exércitos sáo constituídos por escravos com o objectivo único de aniquilar o ocidente. Estamos perante uma perspectiva das Guerras MedoPersas que entende o conflito como um combate entre liberdade e totalitarismo, leitura maniqueísta que, como é evidente, não deixa de ser um problema relativo no contexto em questão. Este é o coração da fita e apesar de incluir uma história de amor protagonizada por uma ficcional sobrinha de Leónidas (Diane Baker), de modo a conferir algum romantismo ao enredo, a mesma não tem força suficiente para se sobrepor à mensagem central do filme.

A reconstituição da batalha das Termópilas passa por ser uma proposta interessante enquanto evocaçáo do acontecimento, levando inclusive alguns autores a considerarem esta película no âmbito do epic film

${ }^{9}$ Lillo Redonet (1997) 146. 
ou superprodução. Ainda assim, são visíveis alguns anacronismos escusados, como a utilização de um mapa da Grécia, por certo desconhecido à época.

Grande parte do argumento assenta, naturalmente, nas Histórias de Heródoto, pois é aí que podemos ler uma extensa descrição destes acontecimentos, reconhecendo-se inclusive citaçóes retiradas do historiador ${ }^{10}$. Mas a relevância dada à figura de Temístocles mostra que Plutarco foi uma das fontes também utilizadas na concepção desta fita. $\mathrm{O}$ estadista ateniense destacou-se pela política de defesa da Ática, investindo na frota da cidade de Atenas, com a qual veio a vencer em Salamina, em 480 a.C. O ethos determinado e ousado da personagem é sem dúvida colhido na Vida de Temistocles, onde lemos acerca da sua ambição e determinação, bem como as informações sobre o percurso e projecto político de talassocracia do governante $^{11}$. Ao contrário da versão de 2006, que foca acima de tudo o confronto no desfiladeiro das «Portas do Inferno», este argumento insiste mais na conjuntura política vivida na Grécia, o que justifica o desenvolvimento da figura de Temístocles. Até o aparecimento da rainha da Cária, Artemísia de Halicarnasso (Anne Wakefield), tema bastante desenvolvido no filme, ainda que seja um tema herodotiano, pode ser igualmente lido na uita do ateniense $\mathrm{e}^{12}$.

${ }^{10}$ Cf. Heródoto 7.

${ }^{11}$ Plutarco, Temistocles 5. O filme concentra-se, porém, na fase da vida de Temístocles até às Termópilas, sendo que o relato de Plutarco vai além disso. Sobre as fontes herodotianas do filme, ver Lillo Redonet (1997) 149-158.

${ }^{12}$ Plutarco, Temistocles 14.4; cf. e.g. Heródoto 7.99; 8.67-70, 87-89, 101-103. 
Apesar de Leónidas não ser uma figura de proa na obra de Plutarco, é também no biógrafo de Queroneia que cineastas e argumentistas têm colhido elementos para compor a sua figura na tela. No tratado que Plutarco escreveu sobre a malícia de Heródoto, o biógrafo de Queroneia afirma que voltará ao tema das Termópilas quando escrever sobre os feitos e a bravura de Leónidas. A intenção seria suplantar as notícias que Heródoto dá sobre o tema nas Histórias. O projecto teria ficado reservado para uma Vida de Leónidas ${ }^{13}$. Acontece que esta suposta biografia do general espartano náo chegou até nós ou nem sequer chegou a ser escrita. Este pormenor teria bastado para pensarmos que as representaçóes da figura do rei de Esparta pouco ou nada deveriam a Plutarco, baseando-se sobretudo nas informaçóes transmitidas pelo Pater Historiae. Mas estaríamos equivocados se o fizéssemos. Com efeito, 300, a recente adaptação do tema das Termópilas ao cinema feita por Zack Snyder (2006), ainda que baseado numa obra de banda desenhada de F. Miller, recorre também, tal como a sua fonte imediata, a Plutarco para a construção das personagens. O processo é particularmente evidente nos diálogos de Leónidas (Gerard Butler), o rei de Esparta, da mulher deste, Gorgo (Lena Headey), e do rei da Pérsia, Xerxes (Rodrigo Santoro). A rainha, por exemplo, diz ao embaixador persa que «só as mulheres espartanas dão à luz verdadeiros homens», o que é um dito atribuído a Gorgo por Plutarco quer na Vida de Licurgo quer nos

${ }^{13}$ Plutarco, Moralia 866B. 
Ditos das Mulheres Espartanas ${ }^{14}$. A proclamação feita pelo rei, à partida para as Termópilas, de que Esparta precisa de filhos tem eco na frase "Casa-te com um bom homem e dá à luz bons filhos» que, segundo Plutarco, Leónidas teria dito à mulher ${ }^{15}$. E nessa sequência ainda, a comovente fala da rainha que diz ao marido "volta com o escudo ou sobre o escudo", sugerindo que prefere vê-lo morto a derrotado ou desertor, provém da mesma fonte ${ }^{16}$. A alusão que no filme é feita por um persa de que as flechas que serão disparadas contra os Gregos taparão o sol - o que aliás é visualmente recriado - e a afirmação de que em consequência disso os Espartanos combaterão na sombra são igualmente transmitidas por Plutarco, que atribui a última delas a Leónidas ${ }^{17}$. A resposta apropriadamente lacónica do espartano à exigência persa para depor as armas, i.e. o arremesso da lança contra Xerxes, é equivalente ao plutarquiano molon labe, expressão grega que significa «Vem buscá-las!» e que se tornou antológica em relação à Batalha das Termópilas ${ }^{18}$ E uma das mais famosas falas do filme, "Almoçai agora como se fosseis jantar no Inferno» (Aidou deipnesontes), surge em dois tratados de Plutarco, nos Ditos dos Espartanos e nas Histórias Paralelas ${ }^{19}$. Também o diálogo entre os reis de Esparta e da Pérsia é, como mostrou N.

${ }^{14}$ Plutarco, Licurgo 14.8; Moralia 240G5.

${ }^{15}$ Plutarco, Moralia 225A2.

${ }^{16}$ Plutarco, Moralia 242F16.

${ }_{17}$ Plutarco, Moralia 225B6. Este tema aparece igualmente em Heródoto, que a atribui a Diéneces, Heródoto 7.226.

18 Plutarco, Moralia 225D11. O contexto literário é o das palavras trocadas entre Leónidas e Xerxes.

${ }^{19}$ Plutarco, Moralia 225D13; 306 D. 
C. Santos, uma recriação feita a partir essencialmente de Plutarco. O confronto entre os dois monarcas baseia-se quer ao nível dos diálogos quer ao nível da imagem no relato do encontro entre Sólon e $\mathrm{Creso}^{20}$ e as falas são extraídas dos Ditos dos Espartanos ${ }^{21}$. A maioria destas referências havia sido já usada por Rudolph Maté, no filme de $1962^{22}$.

Há dois outros filmes de tema grego que incluem temas plutarquianos, embora não sejam propriamente inspirados em narrativas de Plutarco. O primeiro é $L a$ battaglia di Maratona, produção de 1959 realizada por Jacques Tourneur. Como se vêpelo título, a acção centrase naquele acontecimento da História da Grécia. Mas é pertinente para o nosso estudo referir que inclui um grupo ao qual se dá o nome de "Guarda Sagrada», cuja função era assegurar a vigilância da cidade de Atenas. Este pormenor sugere o tema do Batalhão Sagrado. O hieros lokhos é mencionado por Plutarco, mas associado a Górgidas (século IV a.C.) e à cidade Tebas, com o objectivo de defender a cidade dos Espartanos, e não ao que se vê nesta fita. O Batalhão caracterizava-se ainda pela sua natureza homofílica, o que é ignorado por Tourneur, e teria sido derrotado em 338 a.C., em Queroneia. O Beócio todavia conta que a guarnição

${ }^{20}$ Plutarco, Sólon 27.3-4.

21 Plutarco, Moralia 225C-D; como nota Santos (2008), a diferença está no facto de Plutarco dizer que os dois soberanos trocaram missivas entre si. Outro passo do mesmo texto, 225C10, está igualmente implícito no diálogo de contornos também bíblicos. Ver ainda Dias (2007); Loureiro (2007) e Murray (2007).

${ }^{22}$ Eventualmente através do romance de Paul Nord, no qual o argumento do filme se inspira. 
era constituída por trezentos homens, o que permite uma associaçáo ao exército espartano das Termópilas, realidade historicamente mais próxima do tema da Batalha de Maratona ${ }^{23}$. O segundo filme, Damon and Pythias (Curtis Bernhardt, 1962), conta uma lenda grega, a de dois amigos adeptos do pitagorismo, que vivem em Siracusa, no tempo de Dionísio II. No entanto, a lenda conhecida e transmitida por Aristóxeno e Cícero localiza a acção no tempo de Dionísio I e não do filho. No filme, a história é alargada em termos cronológicos. Seja como for, ambos os monarcas são figuras tratadas por Plutarco em vários dos seus textos e a forma como o tirano de Siracusa é representado nesta fita deve por certo parte da sua caracterizaçáo ao que se lê no Queronense ${ }^{24}$.

${ }^{23}$ Plutarco, Pelópidas 18-19. Sobre este assunto ver Rodrigues (2009).

${ }^{24}$ Cf. e.g. Plutarco, Dion, passim. Estes dois filmes pertencem ao género dos pepla. Em 2006, estreou Minotaur de Jonathan English. É uma adaptação do mito de Teseu, que em parte se relaciona com a vida desse herói escrita por Plutarco. Mas o filme é uma fantasia vai muito além do que se lê na uita grega. $\mathrm{O}$ mesmo foi feito por John Madden, na série The Storyteller, do grupo «Jim Henson", que inclui Theseus and the Minotaur (1991), escrito por Anthony Minghella. Como se verifica, realizador e argumentista são aqui nomes de peso. Ambos os filmes focam apenas o mito do Minotauro, ainda que o segundo inclua a personagem de Medeia (Lindsay Duncan), que aparece em Plutarco. Cf. Plutarco, Teseu 12 ; 18-20. Com mais afinidades com o que a tradiçáo grega conta acerca do mito de Teseu, incluindo as fórmulas e informaçóes fornecidas por Plutarco, é Teseo contro il Minotauro, um filme do tipo peplum de 1960, realizado por Silvio Amadio. Os passos plutarquiandos contemplados por este filme são os que se podem ler em Plutarco, Teseu 15-20. 


\section{AleXANDre}

Apesar da importância da figura de Alexandre III da Macedónia na História da Antiguidade Clássica, até hoje, não foram muitos os filmes a ele dedicados. São essencialmente três as produçóes que tomaram Alexandre Magno como personagem central. A primeira, Alexander the Great, data de 1956 e é uma realização e produção de Robert Rossen, que escreveu igualmente o argumento, com Richard Burton no papel principal. A segunda, com o mesmo nome mas originalmente concebida como telefilme, data de 1968 e foi dirigida por Phil Karlson e interpretada por William Shatner. A terceira, simplesmente chamada Alexander, data de 2004 e é de Oliver Stone, com Colin Farrell no papel titular ${ }^{25}$. Além destes, existem outros filmes em que Alexandre da Macedónia aparece, mas cuja fraca divulgação comercial levou a que fossem menos conhecidos. São os casos de Sikandar, uma produção indiana de 1941, realizada por Sohrab Modi, e Megalexandros, produção franco-ítaloalemã de 1980, realizada por Theo Angelopoulos. Para a televisão foi ainda rodado em 1981 The Search for Alexander the Great, ao estilo de documentário dramatizado, com Nicholas Clay (Alexandre), James Mason (narrador), Julian Glover (Filipe II), Gabriel Byrne (Ptolemeu), Ian Charleson (Heféstion) e Jane Lapotaire (Olímpia) nos principais papéis. É ainda de assinalar que, em 2005, se previa a rodagem de um outro filme sobre Alexandre, com direcção de Baz Luhrmann,

${ }^{25}$ Chegou a falar-se em Tom Cruise para interpretar Alexandre, cf. Lillo Redonet (1997) 160. 
com Leonardo DiCaprio no papel titular e Nicole Kidman como Olímpia do Epiro ${ }^{26}$. Aparentemente, esta intenção não saiu do papel.

Centramo-nos essencialmente nas produçóes de 1956 e de 2004, aquelas em que a presença de Plutarco e da sua Vida de Alexandre são mais pertinentes. De um modo geral e sem desconsiderar outras fontes, o argumento escrito pelo próprio Rossen - como mais tarde acontecerá com Stone -, nos anos 50 do século XX, segue quase pari passu a estrutura do texto plutarquiano. Em alguns casos, encontramos mesmo citaçóes directas das fontes antigas, designadamente de Plutarco ${ }^{27}$. Neste filme, assistimos ao percurso do príncipe, desde os presságios manifestados aquando do seu nascimento até à sua morte, passando em revista pormenores como a lenda do nascimento divulgada por Olímpia (Danielle Darrieux) ${ }^{28}$, a educação orientada por Aristóteles (Barry Jones) ${ }^{29}$, a batalha de Queroneia ${ }^{30}$, as dissensóes na casa de Filipe da Macedónia (Fredric March) ${ }^{31}$, o banimento

${ }^{26}$ Carmona (2006) 35. Alexandre foi ainda recuperado em 1997, com Alexander Senki, uma célebre série de animação de origem japonesa (manga), escrita por Hiroshi Aramata e Sadayuki Murai. O tema da demanda pelo túmulo do Macedónio foi incluído num episódio de uma série televisiva norte-americana de grande popularidade no final do século passado, MacGyver (episódio 14, temporada 6 - Eye of Osiris, 1991). Agradecemos à Dra. Nídia C. Santos estas informaçóes.

${ }^{27}$ Esta questão foi tratada por Shahabudin (2010).

${ }^{28}$ Plutarco, Alexandre 3.

${ }^{29}$ Plutarco, Alexandre 7.

${ }^{30}$ Plutarco, Alexandre 9.

${ }^{31}$ Plutarco, Alexandre 9. Sobre esta questão, ver o nosso estudo «O rosto esfíngico das rainhas helenísticas. Olímpia, Laódice, Berenice, Arsínoe, Cleópatra e a leitura grega da alteridade 
dos companheiros de Alexandre ${ }^{32}$, a aura aquilina do general $^{33}$ e a entronização ${ }^{34}$, a batalha de Granico $^{35}$, a relação com Barsine (Claire Bloom) ${ }^{36}$, a batalha de Isso ${ }^{37}$, o encontro com as mulheres da família de Dario III (Harry Andrews) - apesar da fusão das personagens de Estatira Menor e Roxana (Teresa del Rio) nesta sequência ${ }^{38}$-, a morte de Dario ${ }^{39}$, a morte de Clito (Gustavo Rojo) - cena que inclusivamente integra os versos da Andrómaca de Eurípides referidos por Plutarco ${ }^{40}-$, as bodas de Susa ${ }^{41}$ e a morte de Alexandre que, no entanto, em vez de ocorrer em Babilónia acontece em Susa ${ }^{42}$. Os avanços militares e as campanhas alexandrinas são aqui contudo reduzidos ao mínimo, optando-se por uma metáfora apresentada sobre um mapa demasiado moderno para o século IV a.C. Com efeito, o realizador-argumentista privilegia os diálogos à acção, tendo como objectivo talvez uma

feminina» in O Nascimento da Ideia de Europa, vol. II - O Mundo Helenistico (no prelo).

${ }^{32}$ Plutarco, Alexandre 10.

${ }^{33}$ Plutarco, Alexandre 8.

${ }^{34}$ Plutarco, Alexandre 11.

${ }_{35}$ Plutarco, Alexandre 16.

${ }^{36}$ Plutarco, Alexandre 21. Todavia capturada em Damasco, segundo Plutarco, e não em Mileto, como acontece no filme.

${ }^{37}$ Plutarco, Alexandre 19-20.

38 Plutarco, Alexandre 21. O artifício da fusão é muito provavelmente uma soluçáo de economia no argumento. Ambas as princesas foram mulheres de Alexandre, mas, na verdade, Plutarco conta que Roxana acabou por assassinar Estatira, Plutarco, Ale. 77. Chamamos Estatira Menor à filha de Dario III para a distinguir da mãe (Carmen Carulla), sua homónima.

${ }^{39}$ Plutarco, Alexandre 43.

${ }^{40}$ Plutarco, Alexandre 50-52.

${ }^{41}$ Plutarco, Alexandre 70.

${ }^{42}$ Plutarco, Alexandre 73-77. 
perspectiva mais erudita ou intelectual de um tema que facilmente poderia resvalar para o mítico-popular. Essa opção, porém, saiu cara ao produtor e igualmente realizador, dado que os distribuidores decidiram cortar mais de 30 minutos do filme original, por o considerarem demasiado extenso.

Em contrapartida, há intervenções que vão claramente contra o que dizem as fontes plutarquianas, como chamar "Eurídice» (Marisa de Leza) à princesa macedónia que desposou Filipe II a seguir a Olímpia e não "Cleópatra", como referem os textos antigos ${ }^{43}$. Talvez esta opção se tenha devido à intenção de evitar confusóes onomásticas com Cleópatra VII, descendente dos diádocos alexandrinos, perante uma audiência pouco informada. A apresentação de Mémnon (Peter Cushing) como ateniense ostracizado é igualmente engenhosa, mas pouco convincente enquanto elemento plutarquiano. De igual modo, Barsine, que Plutarco diz ser filha de Artabazo ${ }^{44}$, surge aqui sobretudo como a mulher de Mémnon, meio persa meio ateniense, qual metáfora do mundo idealizado por Alexandre. O momento em que Barsine declara ao ainda seu marido

43 Plutarco, Alexandre 9. Cleópatra era sobrinha de Átalo (Stanley Baker). Talvez haja aqui uma fusão com uma outra figura da época, Ada Eurídice, neta de Filipe II, sobrinha de Alexandre e mulher de Filipe Arrideu e que aparece também na produção dirigida por Phil Karlson. Sobre essa personagem, ver Diodoro Sículo 18.39.2-4; 19.11.1-8; e o nosso estudo "O rosto esfíngico das rainhas helenísticas. Olímpia, Laódice, Berenice, Arsínoe, Cleópatra e a leitura grega da alteridade feminina» in O Nascimento da Ideia de Europa, vol. II - O Mundo Helenístico (no prelo).

${ }^{44}$ Plutarco, Alexandre 21. 
mas já mercenário Mémnon que a Pérsia é um mundo a desfazer-se e pronto a ser substituído por uma nova era soa a utopia que poderá estar relacionada com os ideais defendidos por Robert Rossen. Há que ter presente que o realizador, tal como outros intelectuais norteamericanos da época, foi dos que se teve de apresentar à Comissão de Actividades Antiamericanas, por suspeita de ligaçóes ao Partido Comunista, acabando por figurar na lista negra daquele órgão ${ }^{45}$.

Encontramos também anacronismos, como os já referidos mapas que aparecem como instrumentos militares pouco adequados ao contexto, bem como o livro que Aristóteles lê numa das cenas da película.

O tema do homoerotismo, evocado no texto plutarquiano através da caracterização da figura de Heféstion ${ }^{46}$, está praticamente ausente do filme de Rossen, apesar de o argumento incluir a personagem (Ricardo Valle), aliás relegada para segundo plano. Já Bagoas, o eunuco persa por quem Alexandre nutria particular afeição ${ }^{47}$, foi simplesmente esquecido nesta versão cinematográfica. Este será um dos principais pontos diferenciais em relação à produção dirigida por Oliver Stone já no século XXI, traduzindo uma postura consonante com o que se via e discutia em 1956. Mas parte considerável deste filme concentra-se nos episódios macedónicos e familiares da vida de Alexandre. Note-se que metade da fita diz respeito aos primeiros catorze parágrafos da Vida de Alexandre,

${ }^{45}$ Shahabudin (2010) 102-104.

${ }^{46}$ Plutarco, Alexandre 47.9-10; cf. Skinner (2010).

${ }^{47}$ Plutarco, Alexandre 67.8. 
enquanto a outra metade abarca os restantes 62 parágrafos.

Rodado em Espanha, este é dos aspectos que por vezes se torna demasiado evidente, pelo aproveitamento de cenários naturais nem sempre adequados aos contextos que se pretendem apresentar, como acontece com a cena em que uma procissáo passa por uma aldeia medieval espanhola. $\mathrm{O}$ conjunto da cenografia, aliás, não é famoso. A solução para a falta de cenários imponentes que reconstituíssem Péla, Atenas, Persépolis ou Susa é encontrada na instalação de tendas, às quais se adicionam motivos da arte persa ou mesopotâmica. Como se isso bastasse para o impacte visual. De igual modo, em determinadas sequências há claramente um abuso do tema romântico das ruínas clássicas. Por outro lado, é mais convincente o guarda-roupa, em particular o das personagens orientais, que merece uma palavra de destaque pelo cuidado que os figurinistas parecem ter tido ao seguir sobretudo a iconografia da cerâmica ática do século $\mathrm{V}$ a.C. Noutros pormenores não se poupou. Rossen recorreu a 45000 figurantes para darem vida aos soldados de Alexandre, o que por si só representa um número quase cinco vezes superior ao utilizado de facto pelo general quando deixou a Grécia ${ }^{48}$. Quanto à construção da imagem física de Alexandre, tenta-se seguir, como acontece no filme de Stone, o conhecido modelo escultórico helenístico do general macedónio. Mas como acontecerá também com Colin Farrell - também ele demasiado louro para a crítica -, um

${ }^{48}$ Lillo Redonet (1997) 159. 
Richard Burton louro não convence ninguém. Na verdade, Burton louro parece aquilo que precisamente é: Burton a fazer de louro ${ }^{49}$.

Ao nível conceptual, há ainda alguns aspectos a destacar. Tem sido salientada a complexa estrutura freudiana do Alexandre de Stone, mas essa mesma conceptualização do ethos do Macedónio, que na verdade está já presente em Plutarco, havia sido também aproveitada por Rossen. Recordamos, e.g., o momento em que Barsine diz que os únicos rivais que tem na sua relação com o general são a mãe e o pai dele, visto que são esses que Alexandre deseja, acima de tudo, suplantar. Esta perspectiva faz também parte da tragicidade, significativamente enunciada pelas personagens atenienses, que acusam Alexandre de querer tornar-se um deus, insinuando desse modo a hybris da personagem que contribuirá para a conduzir à desgraça ${ }^{50}$. É ainda pertinente e original que o filme de 1956 dedique alguma atenção ao universo ateniense, através das figuras de Ésquines (William Squire) e Demóstenes (Michael Hordern). Com efeito, foram estes homens que, em Atenas, representaram a discussão em torno do pan-helenismo vigente na época.

Há outro aspecto curioso neste filme: o momento em que Barsine desafia as outras mulheres

49 Sobre esta questão ver também Cyrino (2010). A versão menos conhecida, protagonizada por W. Shatner em 1968, é talvez aquela que oferece um Alexandre mais credível a este nível.

${ }^{50}$ Como notou Shahabudin (2010) 100, este episódio, em que Alexandre se reclama filho de Zeus Ámon, relaciona-se especialmente com o Romance de Alexandre. 
que acompanham os Gregos na expedição militar de conquista do Oriente a incendiarem o palácio em que estão instalados, assinalando desse modo a vingança consumada da Grécia em relação à Pérsia e o momento em que podem por fim regressar a casa. A sequência parece-nos ser inspirada num passo vergiliano, mais concretamente no episódio da Eneida em que as mulheres troianas decidem incendiar os navios em que viajaram até Itália, forçando assim os Troianos a fundar a sua nova casa no território em que se encontram ${ }^{51}$. Seguindo esta mesma técnica de recorrer à intertextualidade e usar outro autor clássico além de Plutarco, o argumentista escolheu palavras de Sófocles para encerrar o filme, em consonância com as notas que encontramos na Vida de Alexandre acerca do gosto do Macedónio pelo património cultural grego, em particular pelas tragédias dos dramaturgos atenienses ${ }^{52}$. Ainda que a escolha corra o risco de ser pouco adequada ao contexto: «Muitos prodígios há; porém nenhum maior do que o Homem». Trata-se de uma citação da Antígona de Sófocles ${ }^{53}$.

Apesar do dinheiro gasto na promoçáo do filme, o Alexander the Great de Rossen ficou aquém das expectativas. Talvez o desaire se tenha devido à falta de coincidência entre o que o público esperava, designadamente espectáculo, extravagância e erotismo

${ }^{51}$ Cf. Vergílio, Eneida 5.605-700.

${ }_{52}$ Plutarco, Alexandre 8.3.

53 Sófocles, Antígona 333-334. Citamos a trad. M. H. da Rocha Pereira, Lisboa, FCG, ${ }^{9} 2010,62$. A produção de 1956 é ainda especial para o público lusitano, porque entre o seu elenco encontra-se o português Virgílio Teixeira, que encarna o papel de Ptolemeu, um dos companheiros de armas de Alexandre Magno. 
como acontecera com filmes da mesma época (e.g., Samson and Delilah, Quo Vadis?, The Robe, The Ten Commandments), e o que veio a encontrar de facto ${ }^{54}$.

Quanto ao projecto de Stone, apesar das evocaçóes da infância e da adolescência do herói, a sua proposta concentra-se sobretudo nos oito anos em que Alexandre se afirmou como general e conquistador de um vasto território a oriente da Hélade. Basta este aspecto para assinalar a diferença significativa em relação à obra de Rossen, apesar das várias comunhôes que possamos verificar entre ambos os realizadores e respectivas obras $^{55}$.

Recentemente, I. Petrovic publicou um estudo em que aborda as principais questóes relacionadas com a película e a sua fonte plutarquiana ${ }^{56}$. Como não podia deixar de ser, o contributo da Vida de Alexandre para o filme de Oliver Stone é amplo e significativo enquanto fonte do enredo e do argumento ${ }^{57}$. Há cenas, sequências e iconografias completamente decalcadas do texto grego, de que são exemplos a domesticação de Bucéfalo $^{58}$, a referência ao facto de Alexandre dormir com a Ilíada sob

${ }^{54}$ Como nota Shahabudin (2010) 94-95, o facto de Olímpia se insinuar a jovens com a idade do seu filho ou o de Filipe a rejeitar para se casar com uma rapariga igualmente jovem náo foi suficiente para atrair o público.

55 Sobre esses aspectos, ver Shahabudin (2010).

56 Petrovic (2008).

${ }^{57}$ Apesar de Stone referir que usou outras fontes, como Quinto Cúrcio, Diodoro Sículo, Pompeio Trogo e Arriano, apud Petrovic (2008) 169. Plutarco é, porém, de todos eles, aquele que mais atenção dá ao ethos de Alexandre.

${ }^{58}$ Plutarco, Alexandre 6. 
a almofada ${ }^{59}$, o capacete usado pelo general na batalha de Gaugamelos ${ }^{60}$ ou ainda a construção dos caracteres de Olímpia ${ }^{61}$ e de Heféstion ${ }^{62}$. Outras vezes, fazem-se adaptaçóes do texto plutarquiano, como acontece com o encontro entre Alexandre e as mulheres de Dario III, com Estatira (Annelise Hesme) em particular, aqui colocado em Babilónia e não em Isso, como relata Plutarco $^{63}$.

Mas a principal influência da obra do Queronense faz-se sentir sobretudo ao nível da concepção do filme como um todo. É evidente que ali encontramos os «factos»: a filiação, a ascensão ao poder na Macedónia, os confrontos políticos, as batalhas e as conquistas. $\mathrm{O}$ filme de Stone é aliás bem mais bélico, por exemplo, do que o de Rossen. Mas é também, senão essencialmente, um filme em torno do ethos de Alexandre, um filme de caracteres, o que levou alguns comentadores a elogiarem-no como biopics. ${ }^{64}$

Neste sentido, em Stone encontramos amiúde metáforas e símbolos, eventualmente acessíveis apenas aos que conhecerem de antemão a vida plutarquiana do

59 Plutarco, Alexandre 8.

60 Plutarco, Alexandre 16.7. Plutarco descreve o elmo, mas no contexto da batalha de Granico. Outras sequências inspiradas em Plutarco teráo sido cortadas, como se depreende de Lane Fox (2010) 70 .

${ }^{61}$ Plutarco, Alexandre 2-3.

62 Plutarco, Alexandre 47; 49; Reames (2010) 198.

63 Plutarco, Alexandre 21. A figura da rainha-mãe é também omitida.

${ }^{64}$ É ainda significativo que Stone tenha apontado o Spartacus de Kubrick como um modelo do seu Alexander; apud Shahabudin (2010) 94. 
Macedónio $^{65}$. A forma como o percurso biográfico de Alexandre é apresentado não segue o mesmo esquema linear que encontramos no filme de 1956. Esta nova versão oscila entre as remissóes para o passado e o presente vivido pelo general. Esse jogo de reminiscências permite que o herói desenvolva da forma mais significativa o seu carácter num fundo trágico, à maneira do drama grego que, aliás, como enunciámos, germinava já na escrita de Plutarco. Os dramas familiares são um tema profundamente plutarquiano. É neles que se insere o enredo amoroso, que oscila entre a relação edipiana de Alexandre com a mãe (Angelina Jolie) e as que estabelece com o pai (Val Kilmer) e com a mulher Roxana (Rosario Dawson). Há ainda a vivência afectiva e amorosa com o seu companheiro de armas Heféstion (Jared Leto) e com o eunuco Bagoas (Francisco Bosch), desta vez não esquecido. Que os grandes amores de Alexandre, neste filme, se tenham centrado nestas personagens e não nas várias mulheres com quem se casou, como Estatira, Roxana e Barsine - esta última aliás simplesmente eliminada do enredo - levou a que vários investigadores considerassem o argumento do filme de Stone freudiano e ao mesmo tempo homoerótico ${ }^{66}$.

É a partir de Plutarco que se constrói grande parte da história amorosa entre o general e o seu companheiro Heféstion, quais ecos da parelha Aquiles/Pátroclo. Mas também aquela que se desenrola entre Bagoas e Alexandre $^{67}$. Como foi já apontado, ao longo do filme

${ }^{65}$ Petrovic (2008) 165.

${ }^{66}$ Petrovic (2008) 167.

${ }^{67}$ Plutarco, Alexandre 67.8; Skinner (2010) 128. 
de Stone encontramos as várias facetas da vida sexual do general macedónio: um Alexandre heterossexual, outro bissexual, outro homossexual e outro ainda "trissexual» ${ }^{68}$. Estes são conceitos modernos que pretendem ir ao encontro da época que se pretende retratar no filme, ainda que desconhecidos no âmago da mesma. Neste aspecto, o filme de Stone é particularmente ousado e inovador. É ainda fundamental referir a importância da influência da trilogia que Mary Renault dedicou a Alexandre, também conhecida de Stone, e em que estes aspectos são particularmente valorizados ${ }^{69}$.

Ao lado da tragédia familiar, marca presença a tragédia do poder e das paixóes que, na verdade, sintetiza toda a vida de Alexandre da Macedónia ${ }^{70}$. Talvez tenha sido precisamente este conjunto de factores que levou os críticos norte-americanos a desvalorizarem o filme, apesar de se ter relevado sobretudo uma alegada excessiva colagem do argumento aos factos históricos bem como um alegado excesso de academismo. Por outro lado, é evidente que esta opção de Stone é herdeira da historiografia patética, particularmente importante no período helenístico e na qual, em certa medida, se podem inserir também as biografias de Plutarco $^{71}$.

${ }^{68}$ Petrovic (2008) 182.

${ }^{69}$ Lane Fox (2010) 63. Na tradução portuguesa, estes romances chamaram-se Fogo do Céu, O Jovem Persa e Jogos Fúnebres e foram publicados pela Assírio e Alvim.

70 Skinner (2010) 128.

71 Não entramos na discussão em torno do problema biografia/ história, particularmente significativo no âmbito dos estudos plutarquianos, uma vez que se trata de um assunto que ultrapassa o nosso objectivo do momento. Ainda assim, cf. Plutarco, Alexandre 
Juntamente com o fundo trágico, há ainda o tom épico. Tal como acontece com a tragédia, é também em Plutarco que Stone recolhe essa complementaridade. É o Beócio quem por exemplo associa Alexandre a Aquiles ${ }^{72}$. Nas cenas militares, valorizadas ao longo de todo o filme, é evidente o sabor homérico, na visualização do combate e da refrega corpo a corpo. A sequência da Batalha de Gaugamelos poderia mesmo ter sido inspirada em qualquer momento bélico da Ilíada.

O uso que Stone faz de Plutarco está igualmente patente nas mensagens subliminares que o filme transmite através das personagens de Alexandre, Filipe e Olímpia. No que diz respeito a esta questão, remetemos uma vez mais para o excelente estudo de Petrovic. Mas não podemos deixar de sintetizar algumas ideias que aquela autora apresenta, como são a utilização de uma iconografia mítico-religiosa, que vai do uso da águia estrategicamente utilizada em determinadas cenas, e que aponta para a tradição que dizia que Alexandre era filho de Zeus, às alusóes a Prometeu, Aquiles, Édipo, Medeia, Héracles e Dioniso, algumas colhidas na fonte grega outras complementadas pela perspectiva do próprio Stone, como mostra o caso do herói do mito do fogo. Parece evidente que o desfile destas personagens anuncia aspectos mais complexos do carácter deste Alexandre, como a tal relação de natureza edipiana com a mãe ou a tentativa hercúlea e medeiana de matar o próprio filho,

\section{2; Momigliano (1993).}

${ }^{72}$ Plutarco, Alexandre 8. Sobre as reminiscências épicas do filme, ver Petrovic (2008) 180. 
plantado em Roxana ${ }^{73}$. A apresentação desta galeria de figuras da mitologia e literatura gregas, que se faz no interior de uma gruta, aproxima a cena de uma visão semelhante à catábase clássica, mas que ao mesmo tempo é uma evocação de tipo terapêutico-psicanalítica do herói de tipo freudiano. A sequência valida a proposta de Stone em algo indubitavelmente mais profundo e pouco acessível ao espectador mediano, em particular o norte-americano. Também isso deverá ter contribuído para o desaire comercial e para a crítica pouco favorável de que o filme foi alvo, sobretudo nos EUA.

Mas um dos momentos em que a presença de Plutarco é particularmente forte é o que se vislumbra logo no início, quando o realizador dá voz a Ptolemeu (Anthony Hopkins), que funciona como alter-ego do próprio tratadista grego. Note-se como toda a sequência funciona como uma síntese magistral da cultura grega subjacente à figura e tempo de Alexandre. As estátuas ali presentes, por exemplo, são usadas náo como mera decoração mas como símbolos do carácter de Alexandre ou como paralelos das várias perspectivas que a narrativa pode assumir e das diferentes interpretaçóes de que a personagem pode ser alvo ${ }^{74}$. Petrovic chama mesmo a essa sequência "clever little instruction manual for its [filme] viewing», num inteligente esforço da gestão da imagem do biografado, que assenta nos três géneros utilizados por Plutarco há quase dois milénios: a

${ }^{73}$ Platt (2010) 290; Petrovic (2008). A cena tem igualmente ecos plutarquianos.

${ }^{74}$ Análise particularmente feita por Petrovic (2008) 176-177. 
tragédia, a epopeia e a biografia ${ }^{75}$. Como afirma ainda essa mesma autora, «Stone offered a sophisticated and provocative view of Alexander's character. ${ }^{76}$

\section{Rómulo}

Tal como acontece com Alexandre, não são muitos os filmes dedicados à figura fundacional de Roma. $\mathrm{Na}$ verdade, há apenas uma produção significativa cujo argumento se baseia quase integralmente na vida plutarquiana do primeiro rei romano. Trata-se de uma película italiana, Romolo e Remo, realizada por Sergio Corbucci, em 1961. Apesar de ter alguma influência de Tito Lívio, Plutarco e a sua Vida de Rómulo são sem dúvida a fonte magna deste filme. $\mathrm{O}$ trabalho de Corbucci não é propriamente um épico, à maneira de outras grandes produçóes como Ben-Hur, Quo Vadis? ou mesmo Alexander. É antes um peplum, um tipo de filme, por norma de origem italiana, cuja temática anda em torno de um episódio ou uma personagem da Antiguidade, mas que não constitui propriamente uma superprodução cinematográfica ${ }^{77}$. E, no entanto, os pepla

75 Petrovic (2008) 176. Esta característica é, aliás, inerente ao próprio Plutarco, que oferece ao seu leitor diversas possibilidades de leitura.

76 Petrovic (2008) 183. O «cast estrelado» é um dos pontos fortes desta produção. Aos nomes já citados junta-se ainda o do veterano Christopher Plummer no papel de Aristóteles. De referir que a actriz Jeanne Moreau foi contactada para interpretar a rainha da Pérsia, mãe de Dario III, mas infelizmente declinou o convite de Stone.

${ }_{77} \mathrm{O}$ peplum ficou também conhecido entre nós como «filme de túnica e sandália», por oposição aos de "capa e espada». 
fizeram furor na cultura popular dos anos $50-70^{78}$. A. Collognat define o género do seguinte modo: o peplum inclui «uma tipologia de personagens» que dão corpo a filmes de série B; estes são «menos célebres do que as superproduçóes hollywoodescas..., menos inspiradas do que as obras-primas da sétima arte, como as adaptaçóes de Pier Paolo Pasolini, Michaël Cacoyannis ou Federico Fellini, mas realizadas para o ecrã a partir da literatura antiga. Um número considerável destes modestos pepla italianos pode no entanto oferecer uma excelente ocasiáo para a reflexão sobre a recepção moderna de um tema antigo.» ${ }^{79}$

O Romolo e Remo de Corbucci tem argumento de Sergio Leone e faz toda a justiça ao peplum como género: protagonistas musculados, heroínas que parecem retiradas de revistas de beautiful people, uma ou outra estrela para subir o ego dos produtores, produção europeia (italiana). Rómulo é interpretado por Steve Reeves, que protagonizou um número significativo de filmes do género, enquanto Remo é vivido por Gordon Scott, um actor que começou por ser conhecido no meio não tanto por interpretaçóes ligadas à Antiguidade mas sobretudo pelo seu desempenho como Tarzan. Reeves e Scott acabaram por ser identificados como os reis do peplum. Ainda assim, vários investigadores consideram esta produçáo algo acima da média, relativamente às do género, dada a qualidade de algumas partes, como mostra, por exemplo, a sequência inicial. Trata-se da

${ }^{78}$ Salotti (1997).

${ }^{79}$ Collognat (1998) 64; ver ainda Attolini (1991) 453-461; Lagny (1992). 
cena da fuga de Reia Sílvia (Laura Solari) com os gémeos recém-nascidos, em que não existe uma única fala e em que, contudo, o resultado alcançado é particularmente feliz ao nível do desenvolvimento da narrativa ${ }^{80}$. Dada a sua eficácia, Collognat chega a comparar essa sequência com a funcionalidade da iconografia na pintura. $\mathrm{O}$ objectivo do realizador é plenamente cumprido, visto que a cena proporciona uma espécie de leitura prévia e preparadora das audiências para a metalinguagem utilizada $^{81}$. Mas não podemos deixar de referir que Corbucci e Leone parecem confiar em demasia na cultura clássica dos seus espectadores.

O segundo núcleo do filme concentra-se nos temas do reconhecimento dos gémeos como legítimos herdeiros de Alba Longa, da formação do grupo de salteadores que acompanha os dois irmãos e do rapto das Sabinas. As Sabinas são tratadas como uma metonímia através da imaculadamente loura Júlia (Virna Lisi), a qual é apresentada como filha do rei dos Sabinos, Tito Tácio (Massimo Girotti), e corresponde à Hersília da tradição antiga. Desconhecemos a razão da mutação onomástica $^{82}$. Segundo Plutarco, Hersília era a única das sabinas que já era casada. A personagem de Cúrcio (Jacques Sernas) configura o carácter que faz as vezes de Hostílio, o marido de Hersília nos textos antigos,

${ }^{80}$ Collognat (1998).

${ }^{81}$ Collognat (1998) 65-66.

82 Plutarco, Rómulo 14.7-8. O nome Júlia poderá ser uma evocação do significado e importância dessa forma onomástica na cultura romana do período tardo-republicano e imperial, além de que é um nome mais facilmente identificável com Roma pelas massas do que Hersília. 
ao ser apresentado como pretendente de Júlia. No tratamento da relação entre Rómulo e Júlia verifica-se também a intertextualidade através de apontamentos importados de outros textos, como a cena da chuva que cai sobre os heróis, que se vêem obrigados a refugiar-se numa cabana, onde nasce a paixão, e que é sem dúvida retirada da Eneida ${ }^{83}$. Rómulo e Júlia/Hersília são nesta cena alter-ego de Eneias e Dido, protagonistas de um outro texto fundacional romano e, pelo menos desde o período augustano, intrinsecamente ligado ao tema de Rómulo e Remo ${ }^{84}$.

O terceiro núcleo assenta na expedição dos dois irmãos que desembocará no sulco do pomoerium e consequente fundação de Roma. Mas como nota R. De España, a forma como o tema é aqui tratado lembra mais o topos da caravana presente em qualquer western do que uma sequência de peplum. $\mathrm{O}$ ambiente cowboy está presente ao longo de todo o filme, aliás ${ }^{85}$. É também nesta sequência que somos surpreendidos com a cena menos verosímil de toda a produção, porque estranha ao mito antigo: a erupçáo de um vulcão, ao qual se chama «Montanha Sagrada», que mata grande parte das personagens. Agora parece estarmos perante um filmecatástrofe, género que fez furor nos anos 70 do século passado $^{86}$. Mas é também essa parte do enredo que

\footnotetext{
${ }^{83}$ Vergílio, Eneida 4.130-197.

${ }^{84}$ Galinsky (1996).

${ }^{85}$ De España (1998) 197; Alonso (2008b) 23.
}

${ }^{86}$ A introdução do vulcão deverá estar relacionada com o tema de Os últimos dias de Pompeia, romance que foi várias vezes adaptado ao cinema e que fez escola no género peplum. 
permite ao realizador inserir no argumento o episódio da traiçáo de Tarpeia (Ornella Vanoni), plutarquiano mas redefinido e desfasado do seu contexto original, inusitadamente relacionado com a figura de $\mathrm{Remo}^{87}$. O mesmo podemos dizer acerca da inclusão do tema de Horácio Cocles ${ }^{88}$.

A película termina com a fundação de Roma. Ao contrário da Vida de Rómulo, em que a criação da cidade é uma alínea quase inicial na estrutura do texto, no filme tudo evolui para esse clímax, que coincide com o momento em que os dois irmãos se defrontaráo. A ordem dos factores é invertida ao serviço da eficácia da metanarrativa. Rómulo sulca o solo e Remo, preterido, reage mal, definindo o anticlímax da personagem que, na verdade, vem sendo preparado desde o início. Esta opção narrativa não contraria as fontes e é interessante, visto que, em oposição ao que acontece com as lendas e mitos gregos de gémeos, a hostilidade entre os dois irmãos não se revela na infância, mas sim na idade adulta, contrariando a afectividade inicial que parece predominar entre ambos no início e no mito original romano. Rómulo acaba por matar o irmão, em legítima defesa, de modo a que a reputação do herói não saia manchada no final do filme. Mas apesar da intensidade dramática que o confronto entre os dois irmáos/ fratricídio implica, que se exige ao topos da violência fundadora e que acaba por resultar ao nível do pathos

${ }^{87}$ Cf. Plutarco, Rómulo 17.2-7; 18.1; Rodrigues (2005) 139-144.

88 Que apesar de referido por Plutarco, Publícola 16.6-9, pertence a um outro contexto. Estes são sobretudo temas livianos, ver Rodrigues (2005) 139-144, 179-182. 
sobre o espectador, ainda que este desconheça o mito original, o resultado é sobretudo um filme de aventuras, cujo pretexto é um antigo mito romano. Nem os simbolismos luz/trevas utilizados através das cores dos cavalos e das vestes dos heróis titulares ao longo de boa parte do filme é suficiente para nos convencer da superioridade da produção. Ainda assim, a nossa reacção é ambivalente: se por um lado o figurino dos actores e das actrizes nos remete inevitavelmente para os ambientes dos anos 60, conferindo uma plasticidade artificial à produção a que se junta a estética do western, por outro lado é inegável que nestas cenas existe algo de primitivo consonante com a filosofia do in illo tempore que remete para um tempo de origens. Por outro lado ainda, não é o western no âmbito da cultura contemporânea um género fundacional também? ${ }^{89}$

Mas alguns anacronismos dificilmente passam despercebidos a qualquer leigo no assunto. E não nos referimos apenas aos jeans usado por Tarpeia. As personagens deste filme discutem problemas como a falta de trabalho numa regiáo, de liberdade e de igualdade para todos ${ }^{90}$. Outras referências correm o risco de passar despercebidas a quem não tenha uma formação suficientemente erudita, como é o caso da sequência da festa das Lupercais, em cuja encenação se reproduz o ritual de açoitar as mulheres. Quem não conhecer este pormenor da cultura romana não entende o que ali se vê, pois não há qualquer tipo de explicação

${ }^{89}$ Sobre este problema, ver Viganò (1997).

${ }^{90}$ Alonso (2008b). 
complementar. Supóe-se que, como em qualquer obra de arte, há sempre vários níveis de leitura, de acordo com o receptor. Outro aspecto já notado é o facto de os elementos de maravilhoso e sobrenatural estarem totalmente ausentes desta produçáo, de acordo com o que acontece com a maioria dos pepla ${ }^{91}$.

A partir do episódio do rapto das Sabinas, narrado por Plutarco na Vida de Rómulo, fizeram-se outros filmes que retomam a lenda do rei de Roma, mas que se centram sobretudo naquele tema. Assim acontece com El rapto de las Sabinas, realizado por Alberto Gout em 1960, e com L'enlèvement des Sabines, de Richard Pottier (1961). Sem esquecer, claro está, o já mencionado Seven Brides for Seven Brothers. O primeiro é uma produção mexicana, apesar de rodado em Barcelona. Como é de esperar, Rómulo (Wolf Ruvinskis) é uma das personagens, mas o foco da acção está agora em Hostílio (Lex Johnson), figura em parte propositadamente criada para o filme, em parte inspirada na personagem plutarquiana de mesmo nome ${ }^{92}$. Por outro lado, é de assinalar que este argumento segue no essencial a estrutura da vida plutarquiana de Rómulo, colocando o rapto das Sabinas após a morte de Remo e da fundação de Roma, o que não acontece com o filme de Corbucci, que faz com que o «rapto» aconteça ainda em Alba Longa. O segundo filme resulta de uma coprodução franco-ítalo-iuguslava e assenta no humor e na ironia.

${ }^{91}$ De España (1998) 198; sobre as Lupercais, ver Rodrigues (2005) 220-222. Sendo na sua maioria filmes pouco verosímeis em termos históricos, náo deixa de ser curioso este pormenor de rejeição dos elementos do maravilhoso.

${ }_{92}^{2}$ Plutarco, Rómulo 14.8; 18.6. 
O seu protagonista viria a dar que falar na História do Cinema: trata-se de Roger Moore, que interpreta o papel de Rómulo. Outro nome sonante nesta película é o de Jean Marais, que dá vida a Marte, o pai dos gémeos, elemento que aliás é também pouco comum, ao trazer à colação o tema do maravilhoso num filme com estas características ${ }^{93}$. Outra das curiosidades desta produção é o facto de, no final, se tentar explicar o que aconteceu a Rómulo, que, segundo refere também Plutarco, teria literalmente desaparecido do convívio com os homens aos 54 anos $^{94}$. O filme tenta dar verosimilhança a essa tradição, fazendo com que a personagem abandone Roma, deixando-a entregue ao seu lugar-tenente Numa Pompílio, outra personagem plutarquiana $^{95}$, a quem solicita que divulgue o boato do rapto divino. Mas não deixa de ser caricato que na história surja uma vestal cuja deusa tutelar é Diana e não Vesta. Pormenor, eventualmente, sem importância.

\section{Coriolano}

O Nachleben da Vida de Coriolano escrita por Plutarco foi particularmente feliz na tradição ocidental e, em grande medida, isso deve-se ao facto de, tal como acontece com Júlio César e António e Cleópatra, Coriolano ter tido honras de tratamento dramatúrgico às mãos de William Shakespeare. Este pormenor, não tão pequeno assim, foi suficiente para que a história do general romano que trai os seus para se juntar aos antes

\footnotetext{
${ }^{93}$ A figura de Marte é omissa no filme de Corbucci.

${ }^{94}$ Plutarco, Rómulo 29.

${ }^{95}$ Plutarco, Numa.
} 
inimigos tivesse um percurso razoavelmente distinto do de outros biografados por Plutarco.

E no entanto conhecemos apenas um filme independente - ou quase - das encenaçôes e adaptaçóes filmadas de Shakespeare, que se tenha ocupado do destino de Gaio Márcio Coriolano ${ }^{96}$. Trata-se de Coriolano, eroe senza pátria, dirigido por Giorgio Ferroni em 1964. Esta é uma produção italiana, na linha do peplum, apesar da «nobreza» do argumento. A personagem titular é interpretada pelo já aqui famoso Gordon Scott. Mas este filme dá lugar a algumas novidades. Ao contrário do que acontece em Plutarco e em Shakespeare, o Coriolano de Ferroni não é o verdadeiro «vilão» da história. Esse lugar está reservado a uma outra personagem, Sicínio (Alberto Lupo), que funciona como aquele que desestabiliza a população romana e leva Gaio Márcio a desertar e a trair Roma e os Romanos, juntando-se aos Volscos ${ }^{97}$. Esta opção deverá relacionar-se com o facto de durante muito tempo o «herói» cinematográfico seguir um estereótipo romântico e ser simplesmente isso mesmo: um herói no sentido mais estrito do termo, e não o seu oposto. Os heróis/anti-heróis trágicos praticamente não tinham lugar na cinematografia de cariz mais popular e figuras assumidamente negativas não tinha mesmo qualquer direito ao protagonismo ${ }^{98}$. As audiências

${ }^{96}$ Como é evidente, não levamos em conta o recente projecto de R. Fiennes, assinalado no início deste estudo. Em The Spread of the Eagle (1963), inclui-se também a história de Coriolano, adaptada de Shakespeare.

${ }^{97}$ Sicínio é uma personagem plutarquiana que aparece em Plutarco, Coriolano 7; 13 e 18.

${ }^{98}$ Digamos que uma personagem anti-heróica como Dexter, da 
pediam essencialmente heróis positivos. Assim, a única forma de levar Coriolano ao grande ecrã seria através da modificação do seu ethos. O que acontece neste filme. Note-se como os textos promocionais se referem a Coriolano como "o guerreiro mais valente de Roma», o que não estará longe da concepção original da lenda, mas que neste novo contexto assume uma intencionalidade distinta.

As cenas exteriores, sobretudo preenchidas por movimentos militares, expandem significativamente o guião baseado na estrutura plutarquiana e nos diálogos shakespeareanos, que estáo inevitavelmente presentes. Com efeito, a visita de Volúmnia (a mãe de Coriolano, interpretada por Lilla Brignone), Virgínia (assim se chama a mulher de Coriolano no filme, interpretada por Rosalba Neri) e da terceira matrona romana ao general desertor e empossado entre os Volscos traz-nos de imediato à memória a biografia antiga e a tragédia da autoria do bardo inglês. Não referimos o nome de Valéria, a outra matrona ${ }^{99}$, todavia, porque no filme essa figura é substituída por uma outra criada de propósito para este enredo: Lívia (Angela Minervini), uma irmã de Coriolano, que acentua o carácter dramático e familiar da cena . Por outro lado, são evidentes alguns outros elementos mais profundamente plutarquianos, como o tratamento do problema do abastecimento de trigo a Roma, que na Vida de Coriolano ocupa um

série norte-americana da Showtime, é um fenómeno moderno.

99 A Valéria que Plutarco refere era irmã de Publícola. Cf. Plutarco, Coriolano 33. Este é um tema bastante tratado na pintura. Cf. texto de P. S. Rodrigues neste mesmo livro. 
lugar central ${ }^{100}$, assim como a atribuição do cognome "Coriolano» ${ }^{101}$ ou ainda o saque das cidades satélites de Roma, pelo exército volsco já chefiado por Aufídio (Pierre Cressoy) e Gaio Márcio ${ }^{102}$. O tema do altruísmo de Coriolano em relação ao saque assim como o da obsessão pela vingança de Roma são igualmente inspirados em Plutarco.

O final deste Eroe senza pátria é, todavia, bem alternativo. Em vez da morte de Coriolano, por que Shakespeare opta, Ferroni segue outro desfecho, permitido por Tito Lívio, mas contrariado pelas palavras de Plutarco, que refere a morte do romano às mãos dos Volscos ${ }^{103}$. Em vez de cair sob os golpes dos agressores, Gaio Márcio Coriolano desafia Sicínio num duelo, mata-o e firma a paz entre Romanos e Volscos. O herói opta depois por ficar juntamente com a sua mulher entre aqueles, garantindo assim que o pacto firmado não será violado. Outros ineditismos são visíveis na inclusão de personagens novas, como a já mencionada Lívia, a tal irmã de Coriolano, estranha à fontes antigas, mas conveniente à história, porque permite a inclusão no enredo de uma espécie de "Julieta» apaixonada por um «Romeu» plebeu, um tal Marco (Aldo Bufi Landi),

${ }^{100}$ Plutarco, Coriolano 16.

${ }^{101}$ Plutarco, Coriolano 11.1.

${ }^{102}$ Plutarco, Coriolano 28. O argumento segue a forma "Aufídio» em detrimento de "Tulo».

103 Plutarco, Coriolano 39; cf. Lívio 2.40. Como nota Elley (1984), Ferroni segue Plutarco nos nomes da mulher e da mãe de Coriolano, mas segue Tito Lívio ao deixá-lo sobreviver no final. O nome da mulher de Coriolano em Plutarco, contudo, é Vergília e não Virgínia. 
outra figura desconhecida de Plutarco. A oposição social entre as duas personagens serve essencialmente para marcar a origem patrícia de Gaio Márcio, bem vincada, aliás, pelo Queronense ${ }^{104}$.

Os aspectos plásticos do filme seguem a tradição do peplum. Verifica-se, por exemplo, uma excessiva proximidade às tendências estéticas dos anos 60, característica destas produçóes. Outros pormenores contribuem para a avaliação negativa do rigor cronológico. As armaduras usadas pelos soldados, por exemplo, são historicamente posteriores ao século $\mathrm{V}$ a.C., tempo suposto da acção. Mas não queremos deixar de assinalar o pormenor do aparecimento da loba romana, escultura de origem etrusca, na sala da cúria e do senado, que aparece sem as estátuas dos gémeos. De facto, estas foram-lhe acrescentadas apenas no período renascentista. A atenção a este pormenor parece-nos significativa.

A equipa, os cenários e o guarda-roupa deste Coriolano foram posteriormente aproveitados para um outro filme: Il colosso di Roma, do mesmo realizador, produzido em 1964 e protagonizado também por Gordon Scott. As personagens centrais são aí Clélia e Múcio Cévola, figuras da tradição lendária romana, sendo ele igualmente referido por Plutarco. Ainda que não o suficiente para que no biógrafo se baseasse o argumento desta película totalmente dedicada a Cévola ${ }^{105}$.

${ }^{104}$ Plutarco, Coriolano 1.

105 Cf. Plutarco, Publícola 17. Neste filme, estas personagens, independentes na tradição romana, são unidas pelo casamento. 


\section{Júlio César e os rapazes do SEU TEMPo}

Juntamente com António e Cleópatra, que trataremos de seguida, Júlio César é, talvez, a personagem plutarquiana mais tratada pela Sétima Arte. Para isso contribui, sem dúvida alguma, a rampa de lançamento que a dramaturgia shakespeareana preparou previamente ${ }^{106}$. Ao existir uma peça como Julius Caesar, estão de imediato criadas as condiçóes para que esta se torne uma das mais importantes figuras da galeria criada por Plutarco a ser transportada para o universo cinematográfico. Este factor é tão mais pertinente quanto o facto de Julius Caesar ser, eventualmente e apesar das adaptaçóes, amplificaçóes e omissóes, o texto shakespeareano mais próximo da sua fonte directa: a Vida de César de Plutarco ${ }^{107}$. Praticamente todas as grandes cenas e momentos marcantes da peça podem ser acompanhados de uma nota de rodapé que remeta para o Queronense. $\mathrm{O}$ aviso relativo aos idos de Março, o envolvimento dos conjurados, a intervenção de Pórcia, a reacção de Calpúrnia aos presságios, o pedido recusado de Cimbro, a reacção e morte de César no senado, o discurso de António, a batalha de Filipos são os exemplos mais

106 Sobre esta questáo, ver Humphreys (1984) 8-9. W. Shakespeare teria utilizado a célebre tradução que Sir Thomas North fez das Vidas de Plutarco. Na mesma época, a tradução de Jacques Amyot fez igualmente furor entre as audiências francófonas, influenciando o que nesse domínio se fez inspirado no Beócio. Ver Hamer (1998); Shackford (1929); Alonso (2008) 109.

${ }^{107} \mathrm{Na}$ verdade, as vidas de Bruto, Pompeio, Catão Menor, César e António estão todas referenciadas como fonte da peça, Hamer (1998) 1-11; Humphreys (1984) 1-91. 
evidentes, pelo que os próprios diálogos devem muito ao texto grego ${ }^{108}$.

Como é evidente, figuras como César, António e Cleópatra não são «meras» criações literárias ou ficcionais, como acontece com algumas outras personagens da Antiguidade Clássica. Quase tudo o que sabemos de facto das suas vidas está documentado em fontes antigas. Mas isso não impede o mérito de cada realizador, que recria as formas de entender e interpretar as biografias de personalidades tão significativas na História da Europa, em função dos seus próprios interesses dramáticos e agendas ideológicas. Desde logo, o próprio William Shakespeare contribuiu para o processo ao fixar paradigmas bem significativos na forma de expor estas histórias.

Os filmes dedicados a Júlio César remontam pelo menos a 1914, ano em que em Itália estreou Gaius Iulius Caesar, de Enrico Guazzoni. O filme centra-se na vida do dictator, com Amleto Novelli no papel titular, sendo de destacar aspectos que nem sempre são valorizados nas produçóes mais recentes, como a relação do tribuno com Servília. O tema foi recentemente recuperado pelos argumentistas da série televisiva Rome, apresentada pela HBO (2005), na qual, à semelhança do que acontece com a fita de 1914, se constrói a personagem de Bruto (Tobias Menzies) com base na ideia de que seria filho ilegítimo de Servília (Lindsay Duncan) e de César (Ciarán Hinds). Esta tradição, contudo, enraíza-se

${ }^{108} \mathrm{O}$ discurso de António, por exemplo, é uma amplificação do que se encontra em Plutarco, Bruto 20.4. 
muito provavelmente nas referências que Plutarco faz na Vida de Bruto e na Vida de Catáo Menor acerca dos amores entre as duas personalidades ${ }^{109}$, e coaduna-se com o famoso kai sy teknon, citado por Suetónio ${ }^{110}$. O filme de Guazzoni evidencia-se ainda por focar as campanhas ibéricas e gaulesas de César, com particular incidência na batalha de Alésia ${ }^{111}$, e inclui ainda algumas sequências com Cleópatra. O balanço é uma película aceitável para a época em que foi produzida, com cenas consideráveis do ponto de vista técnico e artístico, e cujo argumento vai um pouco além do texto de Shakespeare. $\mathrm{O}$ mesmo não acontece com outras adaptaçóes da vida de César ao cinema, como a que Joseph L. Mankiewicz realizou e John Houseman produziu em 1953 e que, até à data, será de todas a melhor.

Filmada a preto e branco, esta adaptação surge pela mão do mesmo realizador que uma década depois fará estrear Cleopatra. De certo modo, portanto, a produção de 53 funcionou como um ensaio para o que se lhe seguiu. Apesar de este ser um filme de reciclagem, isto é, que aproveitou cenários e figurinos do Quo

109 Plutarco, Bruto 5.2-4; Catão-Menor 24.1-3; ver Rodrigues (2007). Estas personagens são recuperadas também em Empire (2005). Como se verifica, Plutarco está presente nas adaptações históricas ao cinema desde praticamente os inícios da Sétima Arte. Notam Malamud (2009) 29 e Reinhold (1984) 250-264 que Plutarco foi um autor bastante lido na América do século XIX.

110 «Até tu, filho?», Suetónio, César 82. A referência é feita em grego no original, mas Shakespeare escreve-a em latim, substituindo o termo "filho» pelo nome de Bruto (Et tu, Brute? 3.1) e desvalorizando a probabilidade de Júlio César a ter dito em grego, mas tendo também em conta a erudição da sua audiência.

${ }^{111}$ Cf. Plutarco, César 27; 36. 
Vadis? de Mervyn LeRoy (1951), o resultado não é de forma alguma de segunda categoria. Em grande parte, isso deve-se ao facto de o filme se centrar sobretudo na palavra e na arte retórica, ao serviço do ideário político e magistralmente dominada por Shakespeare, e não na sumptuosidade da imagem cenográfica ou da recriaçáo do acontecimento histórico, no sentido positivista do termo. Como referem Alonso et alii, no filme de Mankiewicz não existem romanos hiper musculados ou armaduras típicas do peplum, porque este é sobretudo um filme de palavras ${ }^{112}$. São elas que fazem com que, em paralelo, se desenrole a tragédia que vinha enunciada desde o texto de Plutarco mas que foi formalizada por Shakespeare. É isso que vemos neste filme: Bruto (James Mason) é a figura trágica por excelência, que se debate perante um conflito interior entre o privado e o público, i.e., ou manter-se fiel a César (Louis Calhern) ou aos valores da República. E a evolução psicológica das personagens reflecte-se sobretudo nos diálogos. Outro exemplo do uso dominante da palavra é a célebre cena do discurso fúnebre proferido por Marco António (Marlon Brando) na escadaria do senado, após a morte de César, em que Brando tem o seu mais memorável e reconhecido desempenho cinematográfico de sempre ${ }^{113}$. Este argumento é tão mais pertinente quanto o facto de o então jovem actor contracenar com nomes consagrados do teatro e do cinema britânicos, como

${ }^{112}$ Alonso (2008) 110.

113 Brando teve uma nomeação para os Óscares com este desempenho. 
John Gielgud (Cássio) ${ }^{114}$, James Mason (Bruto), Greer Garson (Calpúrnia) e Deborah Kerr (Pórcia).

Outro aspecto a salientar na concepção estética do filme, já notado por Roland Barthes, é a apresentação das personagens em grande plano, utilizado para fazer passar as metáforas e os símbolos da tragédia vivida pelas personagens e no qual se evidencia a forma como os actores estão caracterizados e, em particular, penteados. Diz Barthes: «todas as personagens ostentam uma franja de cabelos na testa. Se numas ela é frisada, noutras filiforme, noutras com poupa e noutras ainda untada, todas tiveram o cuidado de a pentear bem... Que é que está assim ligado a essas franjas obstinadas? Muito simplesmente a etiqueta da Romanidade... ninguém pode ter dúvidas de encontrar-se em Roma, no passado.» ${ }^{115}$ Vale a pena citar ainda um outro passo da reflexão de Barthes sobre esta fita: «Outro signo deste Júlio César: todos os rostos pingam continuamente suor: homens do povo, soldados, conspiradores, todos banham as suas fisionomias austeras e crispadas numa transpiração abundante. $\mathrm{E}$ os grandes planos são tão frequentes que, de toda a evidência, o suor é aqui um atributo intencional. Como a franja romana ou a trança nocturna, o suor é também um signo. De quê? Da moralidade. Toda a gente transpira porque toda a gente trava uma luta interior; supóe-se que estamos aqui

${ }^{114}$ Trata-se da primeira aparição de Gielgud no cinema norteamericano. Segundo o próprio actor, ele teria gravado a oração fúnebre de Marco António, a pedido de Brando, para servir de guia a este, ao nível da dicção.

${ }^{115}$ Barthes (1957) 25. 
no lugar de uma virtude que se tortura horrivelmente, quer dizer, no lugar da própria tragédia, e é o suor que tem por função dar disso conta... suar é pensar... Em todo o filme, só um homem não sua, se conserva glabro, mole, estanque: é César. Evidentemente, César, objecto do crime, permanece seco, não pensa, deve guardar a granulação nítida, solitária e polida de uma prova de acusação.»" ${ }^{116} \mathrm{O}$ grande plano, que é como quem diz os rostos, e a palavra substituem a sumptuosidade dos cenários, dispensam qualquer outra iconografia que se torna supérflua.

Por outro lado, se o ambiente recriado fosse de facto essencial, haveria por certo mais cuidado em evitar que, numa das cenas, aparecesse um retrato do imperador Adriano, que viveu cerca de dois séculos depois destes acontecimentos. Ao pretender ser essencialmente uma filmagem da tragédia shakespeareana, todo o filme é feito em cenário e interiores, com a excepção da sequência da batalha de Filipos.

O Julius Caesar de Mankiewicz não é, por conseguinte, um peplum, no sentido estrito do termo, nem propriamente um epic film. É sobretudo teatro feito na linguagem cinematográfica.

Em 1970, a tragédia de William Shakespeare voltou a ser adaptada ao cinema. Desta vez, o realizador foi Stuart Burge, que dirigiu uma série de actores com lugar reservado no star system de então: Jason Robards (Bruto), Richard Chamberlain (Octávio), Robert Vaughn (Casca), Christopher Lee (Artemidoro), Diana

${ }^{116}$ Barthes (1957) 26-27. 
Rigg (Pórcia) e Jill Bennett (Calpúrnia). Também John Gielgud repete a sua presença numa produção desta peça, mas agora no papel titular. O grande destaque vai contudo para o veterano do epic film, Charlton Heston, que encarna o papel de Marco António ${ }^{117}$. Heston é também a figura que consegue dar algum carisma a esta produção. A fita tem alguma originalidade, como o início, em que um narrador off alude à batalha de Munda, vencida por Júlio César em 45 a.C. Mas esta é também uma sequência de algum mau gosto, pois nela vemos um esqueleto caído que parece gritar Aue Caesar! O ponto francamente positivo desta adaptação é a cenografia e os figurinos que seguem a tradição teatral shakespeareana, misturando motivos da Antiguidade e do Renascimento. À semelhança da produção anteriormente referida, também a cena da batalha de Filipos é neste filme a excepção à cenografia de interiores.

O facto é que os filmes sobre Júlio César baseados no texto de Shakespeare são na maioria mais interessantes do ponto de vista da construção da metanarrativa do que aqueles que pretendem recriar a personagem na perspectiva do chamado biopics. Pelo que se tem verificado, de certo modo, o texto isabelino esvaziou a possibilidade de outro argumento brilhar. E esta ideia é válida inclusive para o César de Gabriel Pascal, interpretado por Claude Rains, que em 1946, ao lado de Vivien Leigh, protagoniza a adaptação da peça

117 Refira-se que um dos primeiros papéis de Heston foi precisamente o de Marco António, numa produção amadora, em 1949, e depois em Julius Caesar de David Bradley (1950). 
de George Bernard Shaw, Caesar and Cleopatra, a que voltaremos infra.

Não obstante, foram vários os filmes que tiveram como objectivo principal reconstituir a vida do dictator, deixando para segundo plano a preocupaçáo com a adaptação de qualquer argumento literariamente préexistente. Esse parece ser os casos de Giulio Cesare de Giovanni Pastrone, que interpreta igualmente o papel principal (produção italiana de 1909); Caesar's Prisoners de Theo Frenkel (1911); Oh! Oh! Cleopatra de Joseph Santley (1931); Giulio Cesare, il conquistatore delle Gallie de Tanio Boccia (1962); Giulio Cesare contro i pirati de Sergio Grieco (1962); Deux heures moins le quart avant Jésus Christ de Jean Yanne (1982); Caesar de Uli Edel (2002) e Vercingétorix de Jacques Dorffman (2000), com Klaus Maria Brandauer como César e Christopher Lambert no papel titular, apenas para citar os mais significativos ${ }^{118}$. A estes, poderíamos ainda juntar, numa perspectiva complementar, as produçôes baseadas em Astérix, obra-prima da Banda Desenhada da autoria de Goscinny e Uderzo. Por vezes, quando o argumento não se limita a seguir a tragédia de Shakespeare, a presença do Queronense evidencia-se não apenas através da Vida de César mas também das de outras personalidades coevas do dictator sobre quem Plutarco escreveu. Do mesmo modo, algumas séries televisivas recriaram com frequência o

${ }^{118}$ Uma lista exaustiva pode ser consultada em Carmona (2006) 44-51. Já os Julius Caesar de Frank R. Benson (1911), Dallas Bower (1938), David Bradley (1950) e Leonard Brett (1951) são adaptaçóes de Shakespeare. 
percurso biográfico de César, como Empire (2005) e Rome (2005), ainda que nestes dois exemplos a figura apareça por inerência ao contexto alargado e não per $s e^{119}$.

A obra de Plutarco subjaze a todas estas produçóes, sendo fundamentalmente nela que os argumentistas se basearam para construir os enredos de quase todos os filmes citados ${ }^{120}$. O caso de Rome, êxito assinalável da $\mathrm{HBO}$, é sintomático. O contributo da obra plutarquiana é aí ainda mais significativo. Diríamos que praticamente todas as biografias que Plutarco escreveu sobre personalidades do século I a.C. foram utilizadas para a concepção do argumento original, idealizado por B. Heller, W. J. MacDonald e J. Milius. Centrada em duas figuras ficcionais, Lúcio Voreno (Kevin McKidd) e Tito Pulão (Ray Stevenson), a série conta a história de dois soldados romanos que convivem com aqueles cuja memória foi registada nas biografias que o Beócio dedicou às personalidades romanas do tempo de César. Além do conquistador das Gálias (Ciarán Hinds), lá aparecem Bruto (Tobias Menzies), Pompeio (Kenneth Cranham), António (James Purefoy), Cícero (David Bamber), Catão de Útica (Karl Johnson), Cássio (Guy Henry), Lépido (Ronan Vibert), Octávio (Max Pirkis/ Simon Woods) e até as mulheres Servília (Lindsay Duncan), Ácia (Polly Walker), Calpúrnia (Haydn

${ }^{119}$ Uma outra série, The Spread of the Eagle (1963), reúne as três peças romanas de Shakespeare, com a intenção de dar uma ideia de continuidade aos temas.

${ }^{120}$ Naturalmente, isso não implica a exclusão de outras fontes antigas, designadamente os escritos do próprio César. 
Gwynne), Octávia (Kerry Condon), Lívia (Alice Henley), Cornélia (Anna Patrick) e, como não podia deixar de ser, Cleópatra (Lyndsey Marshal) ${ }^{121}$.

$\mathrm{O}$ mesmo se passa com outras produçóes em que a personagem "Júlio César» não passa de um supporting character no argumento, como acontece precisamente com a maioria dos filmes sobre Cleópatra, que analisaremos adiante, ou ainda sobre outras figuras suas contemporâneas, como Vercingétorix e Espártaco, em relação a quem possuímos informação de substrato também plutarquiano ${ }^{122}$. Destas, destacamos agora precisamente as produçóes cinematográficas inspiradas pelo gladiador trácio, como o Spartacus de Stanley Kubrick, no qual César é interpretado pelo actor John Gavin.

\section{ESPÁrtaco}

Ao contrário do que acontece com quase todos os outros casos aqui estudados, não existe nenhuma Vida de Espártaco escrita por Plutarco que tivesse inspirado ou originado os filmes dedicados a este revoltoso do século I a.C. Existem sim várias referências nas fontes antigas

${ }^{121}$ Figuras mencionadas nas seguintes biografias, nas quais em grande medida se baseia o argumento da série: Vida de César, Vida de Crasso, Vida de Pompeio, Vida de Bruto, Vida de Catão Menor, Vida de Cícero, Vida de António, Vida de Galba. Sobre esta série, ver Cyrino (2008). Naturalmente, foram utilizadas outras fontes, como Suetónio, Apiano e Díon Cássio.

122 E.g., Vercingétorix é referido em Plutarco, César 25-27 e aparece no filme Vercingétorix (2000, de J. Dorffman, interpretado por C. Lambert) e na série Rome (2005, de B. Heller, interpretado por Giovanni Calcagno). 
que pertencem ao corpus plutarquiano. Terá sido em grande parte nestas que os diversos argumentistas que até à data reescreveram a história do gladiador rebelde se inspiraram ${ }^{123}$.

Ocorrida em 73 a.C., a revolta de Espártaco foi adaptada ao ecrã pelo menos cinco vezes: em 1913, por Enrico Vidali ${ }^{124}$; em 1952, por Riccardo Freda (versão alternativa com Massimo Girotti, que incluía uma sequência com a encenação de uma naumaquia, mas que na verdade é um subproduto derivado de filmes anteriores, como o Fabiola de A. Blasetti e o Quo Vadis? de LeRoy); em 1960, por Stanley Kubrick; mais recentemente, em 2004, por R. Dornhelm, numa versão para a televisão com Goran Visnjic e Alan Bates; e ainda em 2010, Spartacus: Blood and Sand, em adaptação igualmente televisiva da autoria de Steven DeKnight, com Andy Whitfield no papel do gladiador trácio. Eventualmente, poderíamos citar ainda uma adaptação hardcore, todavia menos divulgada, em que Espártaco se metamorfoseia num herói da pornografia ${ }^{125}$.

A mais célebre destas adaptaçóes, porém, é sem dúvida a de Kubrick, e essa fama deve-se a vários factores. Todas as versóes referidas são problemáticas, em termos de análise historiográfica, mas as duas

${ }^{123}$ Espártaco é referido por Plutarco nas vidas de Crasso (8-11; 36), Catão Menor (8.1-2) e Pompeio (31).

${ }^{124}$ Esta versão inspira-se no romance de Raffaello Giovagnoli, Spartaco, publicado em 1874. Sobre estas primeiras produçóes, ver Wyke (1997) 37-56; Cyrino (2005) 100-101.

125 Trata-se de Spartacus de Csaba Borbely, datado de 2006. Sobre esta problemática, ver o interessante estudo de Nisbet (2009). 
primeiras são particularmente excessivas no que diz respeito à liberdade poética dos seus realizadores e argumentistas. Em contrapartida, a versão de Kubrick pretende não só ser uma reconstituição mais ou menos fiel do período final da República romana como também uma apologia dos ideais do seu protagonista, realizador e colaboradores, ganhando vida com o auxílio de uma galeria de estrelas do cinema norte-americano e britânico: Issur Danielovitch Demsky, ou melhor, Kirk Douglas (Espártaco), Laurence Olivier (Crasso), Charles Laughton (Graco); Peter Ustinov (Lêntulo Baciato); Jean Simmons (Varínia); John Gavin (Júlio César); Tony Curtis (Antonino) e Nina Foch (Helena). Em parte, repete-se aqui um topos recorrente em Hollywood, o de associar o sotaque britânico às figuras que representam a tirania, e o tom norte-americano às que configuram os heróis, ainda que esta conclusão não seja universal e válida para todos os $\operatorname{casos}^{126}$.

Música (da autoria de A. North), fotografia, guarda-roupa, cenografia, interpretaçóes fizeram com que a versão de Kubrick fosse cinematograficamente quase perfeita ${ }^{127}$. Spartacus é o epic film por definição, distinto do peplum. A filosofia que o sustenta é profunda, assentando no conflito entre a prática da escravatura e o sentimento intrínseco humano da liberdade ${ }^{128}$. Mas esta

${ }^{126}$ Sobre esta problemática, ver o estudo de Wyke (1997), em que se analisa o caso particular do Quo Vadis? de LeRoy.

${ }^{127}$ O filme foi nomeado para seis Óscares da Academia, tendo recebido quatro: cinematografia, direcção artística, guarda-roupa e melhor actor secundário (Peter Ustinov).

128 Elley (1984) 109-112; Solomon (2001) 50-56; Cyrino (2005) 104 . 
associaçáo tem perigos e custos e a crítica náo poupou os autores pelas referências e concepçóes anacrónicas do filme, em parte importadas do romance de Howard Fast que lhe deu origem e que fora publicado em 1951. Algumas dessas concepçóes foram transplantadas para a tela pelo realizador, outras pelo próprio protagonista, $\mathrm{K}$. Douglas $^{129}$. A maioria dos críticos considera que tanto o actor principal (Douglas), como o argumentista (D. Trumbo), como o realizador (Kubrick) transformaram Espártaco num rebelde comunista consciente da pertença a uma classe, que encabeça uma revolta organizada contra o poder instituído, corrupto e decadente, retratado através de uma determinada concepção de burguesia. $\mathrm{Na}$ realidade, vários dos técnicos e autores envolvidos neste filme estavam referenciados pela já referida Comissão de Actividades Antiamericanas, que fez história na segunda metade do século passado. Além disso, o filme nasce no contexto da Guerra Fria, o que transformou todas essas referências em aspectos significativos em termos políticos $^{130}$.

Já no século XIX, Marx reconhecera em Espártaco as virtudes que o levaram a definir a personagem antiga

${ }^{129}$ Ver Alonso (2008a).

${ }^{130}$ Wyke (1997) 59-62. O romance de Fast é rico em metáforas políticas e comparaçóes com temas da contemporaneidade, como a luta pela igualdade de direitos entre homens e mulheres, as problemáticas relacionadas com o sionismo e o homossexualismo. Neste último caso, porém, note-se como, curiosamente, a questão da homossexualidade é usada tanto no romance como no filme como elemento caracterizador da perversão e da decadência moral e política dos Romanos, que por sua vez são apresentados como os vilóes do enredo. 
como "um genuíno expoente do proletariado antigo", enquanto Lenine o havia classificado como o herói de uma das maiores revoltas servis da História e Rosa Luxemburgo e Karl Liebknecht visto nele o mote para o movimento comunista de que fizeram parte no início do século XX: a Liga Espartaquista que incluía uma revista precisamentechamada Spartakus ${ }^{131}$. Aindano séculoXIX, a imagem de Espártaco foi também usada, em particular em Itália, como símbolo da independência nacional, em detrimento do da liberdade individual ${ }^{132}$. A manipulação da figura do gladiador trácio não era, portanto, original. Em termos históricos, é totalmente inverosímil que as motivações de Espártaco tivessem sido as mesmas que moveram estas figuras dos séculos XIX e XX. O mais provável é que a Espártaco tivesse interessado o simples saque e a fuga de Itália, não havendo lugar a qualquer movimento organizado entre escravos e gladiadores. Mas a figura prestou-se a este tipo de leituras e de aproveitamento, que alguns consideram ser sobretudo «clichés esquerdistas» ${ }^{133}$. $\mathrm{O}$ que não implica que o desejo de liberdade e de fuga náo fosse legítimo e não tivesse motivado o gladiador. Com efeito, será honesto referir que já em Plutarco, com o pendor humanista que lhe é característico, se evoca a injustiça das condiçóes a que Espártaco e os companheiros de gladiatura haviam sido sujeitos, quando o autor afirma:

Um tal Lêntulo Baciato mantinha gladiadores em Cápua,

${ }^{131}$ Apud Alonso (2008a) 86.

${ }^{132}$ Cyrino (2005) 101.

${ }^{133}$ Alonso (2008a) 86; Futrell (2001). 
sendo na sua maioria gauleses e trácios. Estes eram prisioneiros, não por terem cometido algum crime, mas por causa da injustiça daqueles que os haviam comprado e que os forçavam a combater na arena. ${ }^{134}$

É um facto que neste filme pouco ou nada é inocente. Situaçóes e personagens assumem papéis claramente metafóricos: o Império Romano é o símbolo do imperialismo norte-americano; o Gaio de Laughton é o paradigma do aristocrata decadente, o bon vivant de cepa estóica que olha para Roma com ironia e ao mesmo tempo nostalgia, um eventual símbolo dos Democratas norte-americanos ${ }^{135}$; o Crasso de Olivier recorda a burguesia dos manuais marxistas ou, mais do que isso, encarna mesmo o alter-ego da sinistra figura do senador McCarthy, particularmente presente nos espíritos norte-americanos de então ${ }^{136}$; as figuras de Helena - inesquecível o ar petulante e lascivo de Foch - e Cláudia (Joanna Barnes) personificam as mulheres burguesas frívolas e fúteis, que se comprazem com as desgraças alheias, por contraponto à leal Varínia de Simmons, que por sua vez simboliza a libertação da mulher e o desejo de igualdade entre os sexos; o lanista Baciato de Ustinov é o arquétipo do comerciante amoral, que "dança» de acordo com a música - as interpretaçóes de Laughton e Ustinov são arrebatadoras o que valeu o Óscar da Academia ao último ${ }^{137}$; o César de Gavin é

134 Plutarco, Crasso 8.2.

${ }^{135}$ Fatás (1990) 36.

${ }^{136}$ Frías Castillejo (2007).

${ }^{137}$ Lêntulo Baciato é mesmo o nome que Plutarco indica para o 
sobretudo um arrivista político, havendo quem o associe ao então recém-eleito J. F. Kennedy; ao passo que Draba (Woody Strode), o gladiador negro, é uma metonímia da população afro-americana nos EUA, assim como David (Harold J. Stone), o gladiador judeu, representa a judaica; e, claro está, o Espártaco de Douglas é a metáfora completa do "proletário revolucionário" que arregimenta tudo o que é escravo para a construção e concretização da utopia ${ }^{138}$.

Mas é sobretudo a utopia que está na base do argumento deste filme, pois historicamente é inverosímil uma tal união de escravos. Aliás, em termos históricos, nem sequer há certeza de que Espártaco fosse escravo, ainda que Plutarco refira a transacção que o levou à casa de gladiadores de Baciato ${ }^{139}$. As referências à vida anterior do gladiador são no filme um tabu, optando-se pela omissão de modo a alcançar o efeito pretendido ${ }^{140}$. Outro pormenor curioso é a construção da personagem de Varínia. Com efeito, Plutarco refere a companheira de Espártaco, que o teria acompanhado na fuga e que seria adepta dos mistérios dionisíacos. Este pormenor é omitido no filme, pois náo seria de bom tom criar uma heroína de contornos marxistas e apor-lhe uma espiritualidade religiosa e mística deste tipo. Mas o autor

lanista, Plutarco, Crasso 8. Ustinov teve um papel particularmente activo no filme ao reescrever grande parte dos seus diálogos. Sobre esta questáo, ver Cyrino (2005) 112.

${ }_{138}$ Sobre a importância do cinema histórico de tema antigo como metáfora da modernidade, ver Winkler (2001a); Futrell (2001); Wyke (1997).

${ }_{139}$ Plutarco, Crasso 8.

${ }^{140}$ Algumas dessas referências constam de Plutarco, Crasso 8-11. 
grego não diz como se chamava essa mulher. A Varínia do filme deve o seu nome a uma outra personagem, igualmente plutarquiana, mas eclipsada na versão filmada: o pretor Públio Varínio, comissionado para resolver o problema dos escravos revoltosos e contra quem Espártaco e os seus combateram ${ }^{141}$. Esta metamorfose de Varínio levou a que alguns considerassem estarmos perante uma razoável dose de ironia e de humor por parte dos autores do argumento e da película ${ }^{142}$. Mas a ironia só se revela eficaz conhecendo o texto de Plutarco.

Igualmente polémico é o final do filme. Segundo as fontes antigas, Espártaco morreu em combate e o seu cadáver nunca foi encontrado. Mas Kubrick faz alinhar o gladiador com outros revoltosos na execução através da crucifixão, o que não acontece no filme de 1952, por exemplo ${ }^{143}$. Talvez esta opção derive não apenas do facto de a morte por crucifixão, conhecida como seruile supplicium, ser a normalmente aplicada a escravos, mas também da intenção de associar o gladiador rebelde à figura e ideais de Jesus de Nazaré, numa versão todavia agnóstica e quiçá herética, uma espécie de «outro lado da mensagem cristã», evocador de temas polémicos mais recentes, como o do casamento de Jesus ${ }^{144}$. As associaçôes ao tema da passio Christi são claras: Espártaco é crucificado e Varínia mantém-se aos pés da cruz

141 Plutarco, Crasso 9.

${ }^{142}$ Fatás (1990) 22. Este filme foi já alvo de uma extensa análise em Winkler (2007). O nome foi retomado na versão de 2004. Ver ainda Theodorakopoulos (2010) 51-71.

${ }^{143}$ Plutarco, Crasso 11.

${ }^{144}$ Como refere Alonso (2008a) 90. 
segurando o filho de ambos; Varínia usa uma túnica azul, símbolo reconhecidamente mariano; a mulher toca os pés do marido crucificado; mais longe, Baciato assiste à cena e apressa Varínia, dizendo-lhe "Tem misericórdia de nós» ${ }^{145}$.

Spartacus é o único filme épico que mostra a vida de gente comum numa época em que a mesma não era fácil ${ }^{146}$. Foi este conjunto de vicissitudes que contribuíram para que o filme sofresse vários cortes, como o da famosa cena homoerótica entre Olivier e Curtis, o da famosa sequência que mostra o sangue sobre o rosto de Crasso ou ainda o da imagem do braço amputado do soldado na cena da batalha final. Algumas dessas cenas só foram reabilitadas nas ediçóes restauradas do filme em 1991.

O essencial do carácter de Espártaco, porém, parece ter sido previamente delineado no texto plutarquiano e daí aproveitado na versão moderna. Eis o que diz o Queronense:

Armados, [os gladiadores fugitivos] escolheram três chefes, sendo o primeiro deles Espártaco, um trácio do país dos $\operatorname{Medos}^{147}$, que reunia uma enorme coragem e força e uma inteligência e candura superiores, sendo por isso mais grego do que a sua origem indicava. ${ }^{148}$

145 Sobre esta cena, Cyrino (2005) 113. A fuga de Varínia e Baciato para a Aquitânia é outro aspecto curioso, que poderia dar ocasião a um debate mais aprofundado, mas que por agora deixamos em aberto.

${ }^{146}$ Solomon (2001) 53.

${ }^{147}$ Os Maedi eram uma tribo trácia.

${ }^{148}$ Plutarco, Crasso 8.3. 
O final do Spartacus de Kubrick deixou em aberto a possibilidade de uma sequela, que veio a acontecer em 1962, com Il figlio de Spartacus ${ }^{149}$. Este filme, contudo, já não é um épico cinematográfico, mas sim um peplum italiano que, à maneira do romance grego antigo, inclui náufragos e se transfere para o Egipto. É protagonizado pelo popular Steve Reeves (Rando) e realizado por Sergio Corbucci. Algumas das personagens são todavia históricas e muito provavelmente de novo recriadas por inspiração dos textos de Plutarco: são os casos de César (Ivo Garrani), Crasso (Claudio Gora) e Clódia (Gianna Maria Canale ${ }^{150}$. Mas como é próprio do peplum, o rigor histórico é uma questão de todo descartável, predominando a fantasia e, apesar de Plutarco sugerir o tema, a adaptação dos seus textos também não é neste filme um problema ou uma preocupação axial.

Espártaco deverá ser a personalidade contemporânea de Júlio César que mais atenção cinematográfica mereceu, e também a mais significativa. Como referimos, há outros biografados por Plutarco que, apesar de não terem tido direito a um filme ou uma série televisiva a si exclusivamente dedicados, aparecem no ecrã sempre que este introduz a figura do dictator. Mas, naturalmente que, quando se aborda a biografia de Júlio César, há duas figuras que lhe são praticamente inerentes: António e Cleópatra, tendo a primeira delas sido igualmente tratada numa biografia plutarquiana.

${ }^{149}$ Filme também conhecido como The Slave.

${ }^{150}$ Os actores que participam neste filme são quase todos veteranos do peplum. Sobre as fontes, cf. Plutarco, Lúculo 34.1; 38.1; Cícero 29; César 10; ver ainda Alonso (2008a). 
A forma como o casal tem sido representado ao longo da História da Cultura Ocidental, e em particular no cinema, porém, faz-lhes merecer também uma alínea específica neste estudo.

\section{António e Cleópatra}

É evidente que quando assinalamos nesta entrada a fórmula «António e Cleópatra», e não apenas "António», como seria mais correcto na perspectiva de Plutarco, remetemos para o imaginário popular que celebrizou o casal em questáo e que em grande parte se deve precisamente aos escritos plutarquianos, eventualmente acentuados pela tragédia shakespeareana e posteriormente difundidos pela imagética cinematográfica. Mas o facto é que, grande parte do que o grande ecrã adaptou, relativamente à vida do tribuno romano e da rainha greco-egípcia, assenta, tal como no caso de Júlio César, em matéria do bardo inglês, não obstante esta basear-se sobretudo na Vida de António ${ }^{151}$.

Até ao momento, a história de António e Cleópatra conheceu mais de uma dezena de adaptaçóes cinematográficas ou televisivas assinaláveis ${ }^{152}$. A primeira data de 1912, confirmando o êxito do tema no cinema praticamente desde os seus primórdios ${ }^{153}$. A produção desse Cleopatra deveu-se aos «Helen Gardner Players»

${ }^{151}$ Wyke (1997) 75.

152 Não incluímos aqui as encenaçóes televisivas de Antony and Cleopatra de Shakespeare. Sobre a recepção do tema de Cleópatra, Hughes-Hallett (1990); Cyrino (2005) 137; sobre as primeiras produçóes cinematográficas, Wyke (1997) 84-97; Wike (2002) 244-320.

153 Trata-se da primeira versão em longa-metragem conhecida. 
de Nova Iorque ${ }^{154}$. Cleópatra foi então interpretada por Helen Gardner, cuja recriação da última rainha do Egipto fez jus à prática da época, sendo evidentes os excessos mímicos e de expressóes faciais, próprios do cinema mudo. Os críticos referem alguns momentos menos conseguidos, como a representação da batalha de Áccio, em que os efeitos especiais levam a que o episódio resvale o humor. $\mathrm{Na}$ verdade, estava-se no início do século $\mathrm{XX}$, os produtores do filme fizeram-no com os meios técnicos que tinham então ao seu dispor e há que ter isso em consideração. A prova de que em 1912 a vida de António e Cleópatra despertou o maior interesse ao nível da cultura popular está no facto de o filme ter feito um périplo pelos EUA, acompanhado de conferências que eram feitas por académicos especialistas na matéria ${ }^{155}$. Tal como a maioria das produçóes que se seguiram, o filme centrava-se na personagem de Cleópatra, mais concretamente nas informaçôes e consideraçóes que Plutarco dá e tece acerca dela na Vida de António, e não na do oficial romano.

O tema da mulher fatal, poderosa e sedutora viria a confirmar-se atraente para o público moderno. Logo no ano seguinte, Antony Novelli e Giovanna Terribili Gonzales protagonizaram uma nova versão da história em Marcantonio e Cleopatra, sob a direcção de Enrico Guazzoni. Pelo título, poderia julgar-se estarmos perante uma adaptação de Shakespeare. Mas o filme acaba de imediato com quaisquer eventuais ilusôes. Trata-se

${ }^{154} \mathrm{O}$ título original deste filme era mesmo Helen Gardner in Cleopatra.

155 Solomon (2001) 62. 
igualmente de uma fita muda, com uma fotografia de inspiração rembrandtiana, em que confirmam as características do cinema da época, mas com inovaçóes que nos induzem à suspeição de que os seus argumentistas e produtores desconheciam de todo a obra de Plutarco, ou que decidiram deliberadamente alterála, com o objectivo de obter cenas e episódios de maior dramatismo. Exemplo desta opção é a cena da morte de Carmiana (Matilde di Marzio), a serva de Cleópatra mencionada por Plutarco, que segundo o autor grego morreu envenenada juntamente com a sua senhora, mas que neste filme é devorada por répteis, numa cena de gosto gore ${ }^{156}$. Outro exemplo é o da sequência em que, no Egipto, Octávia implora a Cleópatra que deixe o seu marido e que mais parece saída de uma telenovela sul-americana do que de qualquer texto greco-latino ${ }^{157}$. Por outro lado, é de assinalar que, ao contrário do que acontece com outras produções, esta mostra o suicídio de Cleópatra não logo a seguir ao de António, mas algum tempo depois, o que parece ir no sentido do que Plutarco escreve acerca da morte da última rainha do Egipto ${ }^{158}$.

Mas aquela que eventualmente foi a Cleópatra mais célebre do cinema mudo chamou-se Theda Bara.

156 Plutarco, António 60.1; 85.4-8; Solomon (2001) 62. Na verdade, no guião original, a serva chama-se Agar e não Carmiana. A versão inglesa, porém, preferiu dar o nome plutarquiano à serva da rainha, talvez devido ao eco shakespeareano. Este bizarro episódio baseia-se num texto oitocentista de Pietro Cossa. Ver De España (1998) 240.

${ }^{157} \mathrm{O}$ mesmo foi já notado por De España (1998) 241.

${ }^{158}$ Plutarco, António 79-87. 
Esta era uma actriz de origem judaica que imortalizou a imagem da vamp no cinema. Foi precisamente esse modelo orientalista que Bara escolheu para a composição da sua Cleópatra, num filme de James Gordon Edwards com o mesmo nome, em 1917, e que por sua vez deverá inspirar-se nos ambientes dos romances oitocentistas e vitorianos de Théophile Gautier e de H. Rider Haggard, bem como na peça de Victorien Sardou ${ }^{159}$. Infelizmente, já não possuímos qualquer cópia desta película, de que restam apenas fotografias. Mas o que sobrou permitenos avaliar a extravagância que foi filmar este Cleopatra em plena Grande Guerra, sendo ainda possível ver uma rainha do Egipto vincadamente marcada por elementos da época da produçáo do filme, designadamente as tendências Art Déco e Arte Nova, presentes nos décors, e que são influenciadas por uma filosofia neo-egípcia ${ }^{160}$. A primeira Cleópatra sonora foi Claudette Colbert e o seu realizador o não menos famoso Cecil B. DeMille. A produção data de 1934, dois anos depois de o mesmo director ter filmado The Sign of the Cross, para o qual chamara também Colbert a interpretar a imperatriz Popeia Sabina. A produção de 34 volta a centrar-se na figura da rainha do Egip to e náo nos seus co-protagonistas masculinos, representados por Warren William (Júlio

159 T. Gautier, One of Cleopatra's Nights (1838); H. Rider Haggard, Cleopatra: being an account of the fall and vengeance of Harmachis, the Royal Egyptian, as set forth by his own hand; Maiwa's revenge; a novel (1889); e V. Sardou, Cléopâtre (1890). Sobre os romances e ensaios biográficos que influenciaram estas produçóes, ver Wyke (1997) 94-95; (2002) 244-278; e ainda Hamer (2002); sobre a estética da época, Curl (2005).

${ }^{160}$ Sobre os elevados custos da produção, ver Solomon (2001) 63. 
César) e Henry Wilcoxon (Marco António). Confirma-se assim a atenção dada pela contemporaneidade a esta figura da História da Antiguidade, privilegiando-a em detrimento das restantes do seu tempo. Cleopatra de DeMille joga obviamente com a presença de Colbert, que era uma mulher vistosa e senhora de uns olhos particularmente apelativos. Mas aposta também nos efeitos especiais e na cenografia, de que se destaca o exemplo da barca da rainha. Como nota R. De España, «habitual em DeMille, o indiscutível brilho visual mistura-se com uma absoluta falta de sentido histórico» ${ }^{161}$. Com efeito, por momentos, o espectador parece estar a assistir a um espectáculo do tipo Ziegfeld follies e não a uma dramatização da vida de António e Cleópatra. O mesmo se diga acerca do banquete em casa de César e Calpúrnia (Gertrude Michael), em que os convivas e a forma como se comportam sugerem os ambientes da alta-sociedade burguesa dos anos 20-30 e de forma alguma a domus de uma família da aristocracia romana do século I a.C. Na perspectiva histórica, os nomes das personagens-figurantes, apesar de clássicos, são inverosímeis enquanto formas onomásticas femininas da época (e.g. Lady Flora, Lady Leda ou Lady Vesta ${ }^{162}$ ).

161 De Espańa (1998) 243. Como nota o mesmo autor, na verdade, jamais saberemos se estas características correspondiam efectivamente aos sentimentos do cineasta ou se simplesmente traduziam aquilo que ele sabia que o público esperava do seu trabalho. Como tem sido notado, a maioria destes filmes diz-nos mais sobre a época que os produziu do que sobre a época que pretende retratar.

162 Personagens interpretadas por Florence Roberts, Celia Ryland e Jane Regan, respectivamente. Apesar de Plutarco, Pompeio 
O mesmo se diga acerca do comportamento social das mulheres que na cena em causa se vêem representadas, tal como o guarda-roupa que envergam ou os penteados que ostentam e que de novo resvalam os ambientes da estética Arte $\mathrm{Nova}^{163}$. Estas ideias são válidas também para a arquitectura dos aposentos privados da rainha ou para a composição das suas aias, inusitadamente platinadas e usando sapatos prateados de saltos altos. Igualmente ridículo é o facto de César passar quase todo o filme com uma coroa de louros sobre a cabeça. Talvez seja para nos lembrar de forma contínua que se trata de Júlio César, o general romano. Mas é sem dúvida um desgaste desnecessário do ícone. Por outro lado, o realizador teve a preocupação de fundamentar historicamente alguns aspectos, como os adornos que Colbert usa ao longo do filme ${ }^{164}$. De assinalar ainda que DeMille utiliza já algumas técnicas de encenação radicadas na pintura e no teatro, que há-de recuperar mais tarde, em produçôes como Samson and Delilah (1949) e muito em particular na segunda versão de The Ten Commandments (1956).

Foram várias as fontes utilizadas por Bartlett Cormack, o autor do guião que fez as adaptaçóes a partir do material histórico. Mas duas das cenas centrais do Cleopatra de 1934 são claramente plutarquianas ${ }^{165}$.

2; 53 nos dar notícia de uma Flora amante de Pompeio Magno.

${ }^{163}$ Questáo abordada por Curl (2005) 382-383.

${ }^{164}$ Solomon (2001) 64-65.

${ }^{165}$ Aqui é possível percebermos outros motivos desenvolvidos tanto por Plutarco como Shakespeare, como o do aviso acerca dos idos de Março (cf. Plutarco, Bruto 10.3; 14.3; 35.4; 40.8; César 63.5-6). O uso de Josefo neste filme é também assinalável, como se 
A primeira é a entrada de Apolodoro, o servo da rainha, carregando um tapete, dentro do qual vem a soberana que assim se apresenta ao chefe romano. A segunda é a da chegada da barca da rainha a Tarso, para o encontro com António. As potencialidades dramáticas e cénicas bem como a centralidade de ambas as sequências na economia do enredo fez com que elas fossem continuamente tratadas. O primeiro episódio é referido na Vida de César, onde se afirma que o siciliano Apolodoro escondeu Cleópatra dentro de um «embrulho» e fê-lo chegar ao general romano ${ }^{166}$. Plutarco afirma mesmo que aquela teria sido a primeira artimanha com que Cleópatra teria seduzido César, elemento que não foi desconsiderado pelos realizadores. O segundo episódio consta da Vida de António e concentra a informação acerca da forma como a rainha seduziu o cunhado de Octávio:

... resolveu subir até Cidno, num navio com popa de ouro, velas púrpura soltas ao vento e remos de prata, que se moviam ao som da música de flautas com siringes e cítaras. Cleópatra ia reclinada sob um dossel de ouro, vestida tal como os pintores representam Afrodite. De ambos os lados dela, abanavam-na com leques, refrescando-a, crianças que pareciam os Amores que se vêem pintados nos quadros. De igual modo, junto a si, estavam as mais belas servas, vestidas como Nereides e Graças, dispostas umas ao lado do leme e outras dos cabos... Corria o rumor que era Afrodite que vinha para partilhar o prazer com Dioniso, para bem da

verifica pela importância da figura de Herodes-o-Grande (Joseph Schildkraut) no argumento.

${ }^{166}$ Plutarco, César 49.2. 
Ásia. António convidou-a para cear, mas ela respondeu que preferia que fosse ele a visitá-la e como ele queria mostrar-lhe cortesia e agradar-lhe aceitou o convite. Ele encontrou tudo preparado de tal modo que está além do que se possa dizer, mas ficou particularmente deslumbrado com a abundância de luzes... ${ }^{167}$.

É esta descrição que serve de mote a uma das mais inesquecíveis cenas do filme de DeMille. Nela, surge o navio com popa em forma de cabeça de cisne, feita em ouro, ao som de um fundo musical que transpira o exotismo do Oriente. Cleópatra não aparece logo reclinada, tal como o texto indica. Além disso, Colbert usa na cabeça uma coifa de tipo egípcio, desenhada a partir da iconografia antiga oriental. Trata-se, portanto, de uma imagem que pouco se coaduna com a ideia das representaçóes de Afrodite. Mas no momento em que António entra no interior do navio, surgem as servas da rainha que, ainda que não se pareçam a Nereides ou a Graças, assumem a função descrita no texto de Plutarco. Aliás, uma vez mais, a coreografia dificilmente executada pelas bailarinas está muito próxima da dos espectáculos típicos da mais pura tradição "hollywoodesca». As crianças referidas pelo texto grego foram também substituídas por homens eroticamente sugestivos que erguem as plumas que refrescam a rainha do Egipto. E esta lá aparece reclinada, ainda que mais com um ar de revivalismo oriental do que propriamente grego. A cena, tal como DeMille a faz representar, recorda-nos

${ }^{167}$ Plutarco, António 26.1-6. 
mais o episódio de Ulisses e Circe na Odisseia, do que a fonte plutarquiana em que é suposto basear-se ${ }^{168}$. Isso poderá dever-se às semelhanças do carácter da Cleópatra de Plutarco com a figura da feiticeira homérica. Cecil B. DeMille utiliza nesta sequência uma coreografia que repetirá anos mais tarde em The Ten Commandments, na cena da adoraçáo do bezerro de ouro, no deserto, por parte dos Hebreus decepcionados com a liderança de Moisés. O António aqui delineado faz jus ao do texto grego, caracterizando-se pela imbecilidade do homem que cede traído pelo estômago, pela ganância, e não só, à inteligência felina e ardilosa da mulher. A cena é misturada com laivos de humor próprio das comédias dos anos 30-40 e culmina numa fantasia extravagante e igualmente "hollywoodesca», enriquecida pela coreografia e pela música de toque oriental, que, apesar de tudo, faz justiça à narrativa de Plutarco. As formas escolhidas pela rainha para seduzir António são uma interpretação das palavras do Queronense, quando afirma que ela «trazia António embevecido com um novo prazer e uma nova graça» ${ }^{169}$. Terá sido mesmo este conjunto de circunstâncias que terá levado Plutarco a referir que António e Cleópatra levavam um estilo de vida inimitável e que conferiu às figuras o glamour que as caracteriza no cinema ${ }^{170}$.

Uma terceira cena no filme de DeMille deve

${ }^{168}$ Cf. Odisseia 10.135-574. De notar em especial os romanos embriagados, que se assemelham aos companheiros de Ulisses no palácio de Circe.

${ }^{169}$ Plutarco, António 29.

${ }^{170}$ Plutarco, António 71. 
parte dos seus créditos à biografia plutarquiana. Trata-se do momento em que a rainha do Egipto experimenta venenos em condenados à pena capital, no sentido de analisar as formas de morte que dali adviriam. No filme, contudo, sugere-se que Cleópatra procedia a tais experiências com vista ao envenenamento de António, acentuando-se desse modo o ethos político da personalidade da rainha e que está de acordo com a ideia de que a lágida usava o romano, enquanto ele lhe devotava uma paixão incontrolável. Esta era uma das atracçóes para o público contemporâneo, que assim via na rainha alguém que colocava o interesse político acima da paixão e do devaneio amoroso, qual vingança consequente do desgosto que Júlio César lhe proporcionara. Em Plutarco, porém, a referência vem num contexto em que se insinua ser ela própria, eventualmente com o amante, $\mathrm{o}$ alvo de tais poçóes ${ }^{171}$.

Reduzida a alguns segundos apenas, a batalha de Áccio está neste filme ainda longe do impacte que terá na economia de produçóes futuras e é na cena final, naturalmente, que se narra o suicídio de António e depois o de Cleópatra. Aí voltamos a aproximar-nos da narrativa plutarquiana. Apesar de o enquadramento ser diferente do que conta Plutarco, o dramático episódio da áspide, aliás problematizado pelo autor antigo ${ }^{172}$, é o que mais se destaca no final do filme de DeMille. Apesar de haver diferenças evidentes: a picada do réptil é aqui dada no peito e não no braço, como refere o tratadista, e

${ }^{171}$ Plutarco, António 71.

172 Plutarco, António 86. 
Carmiana (Eleanor Phelps) e Iras (Grace Durkin), as aias de Cleópatra, não morrem na mesa ocasião, como se lê no texto grego ${ }^{173}$. DeMille também rejeita o esteréotipo da aia negra e da aia caucasiana, seguido noutras produçôes. Em vez disso, oferece-nos duas loiras platinadas, inverosímeis é verdade, mas funcionais do ponto de vista da estética dos anos 30 do século XX.

A Cleópatra que ficou para a História do cinema e para o imaginário popular foi, sem qualquer sombra de dúvida, a que Elizabeth Taylor interpretou para o filme de Joseph L. Mankiewicz, em 1963. Mas para trás ficaram várias outras composições e recriações, como as de Vivien Leigh (Caesar and Cleopatra, 1946) e de Rhonda Flemming (Serpent of the Nile, 1953).

No primeiro caso, rodado ainda em período bélico ${ }^{174}$, a célebre actriz inglesa reencarnou a personagem criada pelo dramaturgo George Bernard Shaw, ao lado de Claude Rains, que nesse filme deu vida a Júlio César. $\mathrm{O}$ argumento da peça, e por conseguinte do filme realizado por Gabriel Pascal (o próprio Shaw escreveu o argumento para o filme), centra-se no primeiro encontro entre o dictator e a jovem soberana. Nesta versão, que passa por ser mais um caso de uma encenação filmada, emerge uma rainha ingénua e ainda imatura, que passa por ter uma relação paternal com César, em detrimento da imagem erótica predominante na restante cinematografia. $\mathrm{Na}$ verdade, nesta leitura, é César quem ensina Cleópatra a ser rainha. Além do

173 Plutarco, António 75-76.

${ }^{174} \mathrm{O}$ custo do filme trouxe alguns dissabores ao seu realizador precisamente por causa desta questão. 
tema, pouco há de Plutarco aqui. A própria serva da monarca é designada por um exótico "Ftatatita» (Flora Robson), nome bem distinto, e mais propício ao humor - e há que salientar que Shaw pretendia uma comédia e não uma tragédia -, dos que Plutarco refere serem os das servas de Cleópatra ${ }^{175}$.

Quanto à versão de William Castle, apesar de o título sugerir a tragédia de Shakespeare (na qual lemos o verso atribuído a António: Wherés my serpent of old Nile ${ }^{\text {116 }}$ ), ela surge como uma proposta inusitada, em que a rainha dedica os seus amores não a António (Raymond Burr) mas ao melhor amigo deste, uma personagem chamada Lucílio (William Lundigan), inspirada num passo de Plutarco ${ }^{177}$. O mais curioso é que o próprio António parece não prestar muita atenção à rainha, pois também ele aparenta estar mais interessado no mesmo Lucílio do que em Cleópatra. Como nota De España, «as cenas em que [António e Lucílio] aparecem juntos têm um inegável sabor homossexual ${ }^{178}$. Trata-se portanto de uma subversão total da história, tal como as fontes antigas a apresentam ${ }^{179}$. Na verdade, todo o filme

${ }^{175}$ Ftatatita é magistralmente interpretada por Flora Robson. Note-se como César tenta desesperadamente dizer o nome da serva, acabando por nomeá-la com um simples «Tota», e conquistando o público com o apontamento humorístico.

${ }^{176}$ Shakespeare, Antony and Cleopatra 1.5.25.

177 Cf. Plutarco, António 69.1-2; Bruto 50.

${ }^{178}$ De España (1998) 245.

179 Ainda que a homofilia de António não esteja excluída das fontes antigas, essa não é a tónica principal na caracterização da sua figura. Não é impossível que a criação do António de Burr se inspire nas referências joséficas à atracção que o tribuno mantinha por Aristobulo, o cunhado de Herodes-o-Grande, Josefo, Antiguidades 
é uma subprodução. O guarda-roupa e a decoração, por exemplo, foram um aproveitamento dos utilizados nesse mesmo ano na rodagem de Salome de William Dieterle, com interpretação de Rita Hayworth. Apesar de o enredo e alguns diálogos sugerirem a radicação shakespeareana, o resultado final está muito longe da qualidade desejada. Para tal, contribuem não só os elementos já aduzidos, como também anacronismos evidentes, de que se destacam os bilhetes escritos em inglês, o aparecimento de dominatrices ao estilo soft-porn na cena da barca, as estruturas arquitectónicas que lembram os interiores de algumas dependências bancárias novaiorquinas dos anos 50, as tiradas dos soldados egípcios - como «Get the girll» -, mais próprias do western, mas que pretendem ser uma ordem para prender a irmá fugitiva de Cleópatra VII, ou ainda sequências menos bem conseguidas como a do suicídio apressado da rainha na sequência do do tribuno romano. Nota positiva merece todavia a composição de Rhonda Flemming, apesar de tudo uma Cleópatra convincente, mais até do que qualquer outra das suas antecessoras ou mesmo sucessoras. A voz profunda e o olhar esmeralda reptilíneo, enquadrado pelas perucas que permitem uma estética de época verosímil, somaram pontos a favor da actriz que será o único elemento positivo deste filme ${ }^{180}$. Novidade em relação aos enredos em torno de Cleópatra é a inclusão da irmã da rainha, Arsínoe (Jane Easton), num argumento que, apesar

Judaicas 15.25-30.

${ }^{180}$ Efectivamente, segundo Plutarco, um dos atributos de Cleópatra VII Teia Neotera Filopator era a voz, o que valoriza a prestaçáo de Flemming. Ver Plutarco, António 27.2-4. 
de tudo, mantém alguma proximidade com o que as fontes antigas referem, designadamente Flávio Josefo, que dá testemunho desta filha esquecida de Ptolemeu Auletes XII ${ }^{181}$. Mais directamente plutarquiana é a cena da chegada da barca de Cleópatra a Tarso. Mas a forma como Castle a apresenta é «cecilbedemilliana». Foi por certo na versão de 1934 que este realizador se inspirou para dirigir a sequência em causa, como prova a coreografia das bailarinas de Cleópatra e o momento em que António lança moedas aos servos. Como nota G. N. Daugherty, «screenwriters and producers may not always read the ancient sources, but they do watch old movies and draw upon popular culture in general.» ${ }^{182}$ Carmiana (Jean Byron) é uma das personagens referidas por Plutarco com algum protagonismo no filme, mas o que aconteceu a Iras?

Do período que vai de 1934 a 1963, anos que correspondem às produçôes de DeMille e de Mankienwicz, fazem ainda parte os filmes de Mario Mattoli (Due notti con Cleopatra, 1953), Vittorio Cottafavi (Le legioni di Cleopatra, 1959) e Victor Tourjansky (Una regina per Cesare, 1962). Nenhum deles prima pela excelência estética, artística ou narrativa. O primeiro é uma comédia de segunda categoria, fraca precursora do futuro Carry on Cleo, que define Cleópatra com um cliché: "Messalina do Nilo». Trata-se por conseguinte de uma versão que insiste no aspecto erótico do tema, para o qual contribui uma

${ }^{181}$ Josefo, Antiguidades Judaicas 15.89-90.

182 Dougherty (2008) 145. 
quase estreante Sophia Loren, que encarna o papel da rainha qual ninfómana, cujo passatempo é executar os variados amantes na manhã que se segue às noites de amor. Anacronismos óbvios e tentativas desesperadas, mas mal sucedidas, de humor fazem parte da receita. Ao lado de Loren, Alberto Sordi tenta salvar a comédia no papel de Cesarino, nome nada inocente do mercador egípcio que se torna guarda da rainha. Mas o que ali nos faz rir é sobretudo o nonsense da película em si mesma, cujo enredo assenta na personagem ficcional de uma escultural escrava sósia de Cleópatra, de nome Nisca, igualmente interpretada por Loren, todavia loura, por meio da qual se engendra uma história de enganos de sabor plautino, mas totalmente falhada.

Quanto ao segundo filme, vem na linha do de W. Castle, centrando-se sobretudo nos momentos pós-Áccio. Nestas produçóes, a não ser o tema, pouco há de Plutarco. A insípida Cleópatra de Cottafavi (Linda Cristal), por exemplo, assume um papel de bailarina cuja verdadeira identidade é desconhecida pelos que a rodeiam. Este é um topos comum, atribuído desde a Antiguidade a várias figuras de poder com fama negativa, como Messalina ou $\mathrm{Nero}^{183}$, mas desconhecido nas fontes antigas em relação à última rainha lágida. Deverá tratar-se de uma importação temática, contaminada de outras figuras, portanto. Como tem sido notado, o António (Georges Marchal) desta versão tenta introduzir um ideário político que justifique a sua inimizade com

${ }^{183}$ Sobre Messalina, ver Juvenal 6.118; sobre Nero, ver Suetónio, Nero 26. 
Octávio (Alfredo Mayo). Mas a proposta apresentada é de todo inverosímil, pois o general defende uma República quando ele próprio se porta como um monarca e de tipo oriental ${ }^{184}$. De qualquer forma, este último aspecto vai ao encontro das linhas plutarquianas. Já o anterior...

O terceiro filme deste período centra-se na vida de Cleópatra na corte ptolemaica até à chegada de Júlio César. Os protagonistas da acção são a rainha (Pascale Petit) e seu irmão-marido, Ptolemeu XIII (Corrado Pani). De salientar é a presença do texto de Plutarco na cena da morte de Pompeio, bem como nas questôes em torno da relação de Roma com o Egipto ${ }^{185}$. Mas este enredo é sobretudo um terreno fértil para desenvolver a ficção, como a que dá vida à figura de Aquiles (Giorgio Ardisson), oficial egípcio que salva a sua rainha das mãos do irmão e se transforma no primeiro amor da soberana. Dada a coincidência do nome, talvez este Aquiles seja uma recuperação do que em Plutarco aparece como conselheiro de Ptolemeu XIV e que foi encarregado de executar Pompeio ${ }^{186}$. Mas se o é, a liberdade poético-artística dos autores é significativa. De certo modo, este filme é propedêutico em relação ao que se lhe segue.

Em 1963, estreou Cleopatra de Joseph L. Mankiewicz. O historiador J. Solomon chama a esta película a «quintessential version» dos filmes dedicados

${ }^{184}$ De España (1998) 246; Aknin (1998).

${ }^{185}$ Cf. Plutarco, Pompeio 77-79.

${ }^{186}$ Cf. Plutarco, Pompeio 77.3; 78.1-7; 79.1-5; 80.8; César 49.10. 
à última rainha do Egipto $^{187}$. Para protagonizá-lo, foi escolhida Elizabeth Taylor que, segundo se diz, não terá ficado muito entusiasmada com a proposta ${ }^{188}$. Talvez por isso mesmo, terá pedido um milhão de dólares de honorários acrescidos de dez por cento da bilheteira, esperando que os produtores da Twentieth Century Fox a recusassem. O que, todavia, não aconteceu. Mas o cachet de Liz Taylor foi apenas uma parcela da enorme despesa que este filme significou para a empresa produtora. Cenários gigantescos afectados pelos mais diversos acidentes do quotidiano, filmagens itinerantes entre Itália e os EUA, passando pelo Reino Unido, trocas de realizador e de actores ${ }^{189}$, doença da actriz principa ${ }^{190}$, compra de direitos de filmes potencialmente concorrentes ${ }^{191}$, escândalos amorosos e sexuais, tudo contribuiu para que este Cleopatra ganhasse fama de o maior épico cinematográfico de todos os tempos e talvez um dos mais conturbados ${ }^{192}$. Uma adjectivação

${ }^{187}$ Solomon (2001) 67.

188 Para o papel titular foram antes considerados nomes como Joan Collins, Audrey Hepburn e Susan Hayward.

189 Os papéis de Júlio César e Marco António teriam sido inicialmente pensados para Peter Finch e Stephen Boyd, que na época protagonizou também Ben-Hur, ao lado de Charlton Heston, e The Fall of the Roman Empire, com Sophia Loren e Alec Guiness. O nome de Laurence Olivier foi também sugerido para interpretar Júlio César, mas o actor declinou o convite.

${ }^{190}$ Que obrigou os médicos a fazerem uma traqueotomia em Taylor.

${ }^{191}$ Como aconteceu com o filme de Vittorio Cottafavi, Le legioni di Cleopatra, que, por mais surreal que nos pareça, terá emergido aos contemporâneos como uma possível ameaça ao êxito do projecto da Fox, ver De España (1998) 248.

${ }^{192}$ Uma síntese da atribulada história desta produção pode ser 
eventualmente exagerada, porém... A não ser que contemos com a duração do filme - 264 minutos - e os custos que atingiu - trinta milhóes de dólares ${ }^{193}$.

De facto, se os filmes rodados nos anos 50 pertencem sobretudo ao género do peplum, o Cleopatra de Mankiewicz é o epic que veio a tornar-se um dos filmes mais controversos da História do Cinema. Sem prejuízo para o facto de ser igualmente um dos mais espectaculares alguma vez realizado. A história de amor que se revelou durante as filmagens entre Taylor e Burton funcionou como uma poderosa alavanca publicitária, que intencionalmente confundia a vida real com a das personagens vividas na tela pelos actores ${ }^{194}$. Em causa estava a construçáo do "mito Taylor", que de certo modo ainda hoje perdura e que se baseia em muito na vida amorosa da actriz, em particular nos sucessivos e atribulados casamentos.

Quando estreou, em Junho de 1963, o filme tinha uma duração de $4 \mathrm{~h} 24 \mathrm{~m}$. Mas duas semanas depois, tinha

lida em Solomon (2001) 67-70. Este é também um dos filmes de tema antigo mais estudados. Ver e.g. Sales (2009).

${ }^{193}$ Note-se, porém, que o tempo de cenas filmadas ultrapassa as 96 horas, Solomon (2001) 67.

${ }^{194}$ A expressão de Plutarco «os da vida inimitável» caía como uma luva à dupla Taylor/Burton. A este propósito, lembramos que em 1960 Fellini rodava La dolce vita, cuja filosofia de base estava muito de acordo com o que agora se via no ecrã. A este propósito, não deixa de ser pertinente que, no momento em que Liz Taylor aparece sentada sobre o trono-esfíngico-móvel, os mais de 4500 figurantes presentes começaram a gritar «Liz! Liz!», em vez de "Cleópatra! Cleópatra!». Na verdade, a reacção dos figurantes, que está na origem do termo "Lizpatra», está mais de acordo com aquilo a que De España (1998) 251 chama de "estética Broadway» da sequência. Ver Solomon (2001) 74, e Wyke (2002) 302-315. 
já apenas $4 \mathrm{~h} 03 \mathrm{~m}$. E meses depois, contava com somente três horas. Estranha metamorfose que levou os críticos a chamarem-lhe The Amputee ${ }^{195}$ e que por certo se deveu às exigências comerciais. Com efeito, em muitos aspectos, o resultado não foi de todo o esperado. A própria Elizabeth Taylor, depois de ter assistido à estreia, considerou o filme uma peça vulgar. Ao que parece, a actriz tinha consciência de que parte dessa vulgaridade se devia a ela própria, pois chegou a oferecer-se para dobrar algumas das cenas em que intervinha, de tão má que era a qualidade da sua voz na película. A voz pouco encorpada de Taylor associada ao sotaque da actriz é de facto um dos pontos fracos na composição da figura da rainha, o que se agrava quando levamos em conta o elemento já assinalado e atribuído a Plutarco, segundo o qual a voz de Cleópatra era um dos atributos mais atraentes da soberana ${ }^{196}$. O produtor, todavia, recusou-se a gastar mais dinheiro com a fita.

Mas é também inegável que o filme possui qualidades como a belíssima música de Alex North - que pouco antes compusera a de Spartacus -, em particular o Cleopatra's Theme da abertura, as reconstituiçóes de Alexandria e de Roma, os figurinos, cenografia e set decoration e as representaçóes de Rex Harrison (César) e Richard Burton (António).

Seguindo o modelo plutarquiano, o António de Burton emerge sob o signo de um homem fraco, moralmente desintegrado, submisso às paixóes, dissoluto

195 Apud Solomon (2001) 69.

196 Plutarco, António 27.2-4. Segundo Solomon (2001) 70, a voz de Taylor é a terceira grande fragilidade do filme, juntamente com a sua duraçáo e montagem. 
mesmo. O produto final preocupa-se em mostrar essa faceta, desprezando a imagem de homem de confiança de Júlio César que António fora também um dia, dadas a sua competência e qualidades estratégicas. Esta opção resultou não da realização do filme mas dos cortes que os produtores decidiram efectuar para tornar a produção economicamente viável. Pois, na versão integral, o António de Mankiewicz era uma fiel leitura de Plutarco, em que a estrutura psicológica do tribuno se ia desagregando, de modo a construir uma imagem trágica da personagem. Essa representação ficou comprometida no metatexto, pois a queda do herói tornou-se omissa, ao apresentá-lo já caído. O mesmo pode dizer-se em relação à intenção de mostrar Cleópatra como uma mulher mística, dependente de oráculos e superstiçóes, tal como o texto de Plutarco sugere. Uma vez mais, a montagem final do filme praticamente anulou essa característica da rainha ${ }^{197}$.

Como noutras produções, a relação de César e Cleópatra é algo exagerada, havendo intenção de intensificar a aura erótica da mesma. Esta leitura vai um pouco além do que recolhemos em Plutarco, embora não o contradiga. Mas é indiscutível que a relação amorosa entre a rainha e António é o centro e o motor deste filme. Tal como em versóes anteriores, designadamente na de DeMille, a cena da chegada a Tarso é uma das grandes apostas dado o impacte visual que proporciona ao espectador, mas também pela envolvência erótica que acarreta. Mas se DeMille havia recorrido a um

${ }^{197}$ Plutarco, António 54; ver Solomon (2001) 71. 
modelo mecânico para «sugerir» os exteriores da cena, Makienwicz optou por investir e construir uma barca em tamanho natural e filmar a sequência na baía de Nápoles. Além disso, o realizador não prescindiu da descrição plutarquiana, segundo a qual a rainha se aproximou de Tarso viajando na barca tal como Afrodite, quando era pintada pelos artistas ${ }^{198}$. De igual modo, as vestes aí usadas por Marco António, designadamente a túnica de pele de felino, remetem para a figura de Héracles, à qual Plutarco o associa ${ }^{199}$. O mesmo se diga a respeito do banquete báquico que se segue, que permite definir as personagens da rainha e do tribuno de acordo com as comparaçóes e os epítetos que Plutarco faz e lhes atribui: a associação aos deuses e heróis - Dioniso/Afrodite, Héracles/Ônfale que lhes valeu passarem a ser conhecidos por aqueles que levavam uma vida inimitável, a que aludimos ${ }^{200}$.

A única cena que no filme rivaliza com a da chegada a Tarso, pela imponência, é a da entrada da rainha em Roma, que, no entanto, não corresponde propriamente a uma recriação de Plutarco. Em termos de análise historiográfica, essa mesma cena, ficou também marcada pelo anacronismo grosseiro, pois nela figura o arco de Constantino, ainda que com pequenas alteraçôes, que viria a ser construído apenas mais de três séculos depois ${ }^{201}$.

${ }_{198}$ Plutarco, António 26.1-6.

199 Plutarco, António 4.2.

${ }^{200}$ Plutarco, António 25.

${ }^{201}$ Em defesa do filme histórico, alguns autores têm sustentado que é de ambiente e de sugestão que a fita necessita e não de absoluto rigor histórico. É uma posição defensável, claro. 
Apesar de alguns considerarem a sequência de Áccio particularmente realista, também neste caso Plutarco não foi de grande ajuda, ainda que os parágrafos a ela dedicados sejam dos mais informativos. Mas a acção exigida pelo metatexto vai além das descriçóes plutarquianas, não se compadecendo da longa descrição textual ${ }^{202}$. Eventualmente, a fuga de Cleópatra no meio da refrega e a reacção de António poderão ser de lá decalcadas ${ }^{203}$.

Como acontece com outros casos, no final, o filme reaproxima-se do biógrafo beócio. Apesar de alguma da informação da Vida de António ser liminarmente elidida, tal como algumas personagens ${ }^{204}$, por serem pouco atraentes para a economia cinematográfica, o enredo que gira em torno do suicídio é aproveitado, talvez na sequência da opção de Shakespeare. $\mathrm{O}$ episódio do encerramento de Cleópatra e das servas no túmulo, que em Plutarco recupera o mito egípcio de Ísis e Osíris, é também chamado à colação por Makienwicz ${ }^{205} \mathrm{e}$ fecha o filme com chave de ouro. O essencial da sequência final, todavia, é indiscutivelmente shakespeareano.

A Plutarco devem-se ainda as sequências do tapete transportado por Apolodoro e a recriaçáo de uma Cleópatra culta e erudita. Outros apontamentos são

202 Plutarco, António 61-68; sobre as vicissitudes ligadas a esta cena, ver Cyrino (2005) 141.

${ }^{203}$ Plutarco, António 66.

${ }^{204}$ Como Eros, o escravo de António, Plutarco, António 76, aqui substituído por Apolodoro, o servo de Cleópatra.

${ }^{205}$ Plutarco, António 77-79. Sobre este episódio, ver Rodrigues (2002) e bibliografia aí citada. O tema de Ísis e Osíris é, por si só, um tema plutarquiano, pelo que neste caso estamos perante uma dupla influência do moralista, cf. Plutarco, Moralia 351Css. 
particularmente notáveis, como o do momento em que Febo, o cantor cego, diz para a rainha um poema que, dada a referência a Lésbia, sugere a obra de Catulo. A composição das aias da rainha segue a tradição de mostrar uma mais morena do que a outra - Carmiana (Isabelle Cooley) que aqui não é negra, e Iras (Francesca Annis) que no caso é mesmo loura. Mas não deixa de ser estranho que também aqui elas surjam praticamente mudas, quando Plutarco lhes confere relevância política ${ }^{206}$. Na verdade, o protagonismo plutarquiano de Carmiana e Iras é anulado em praticamente todas as adaptações cinematográficas até hoje feitas da vida de Cleópatra.

Cleopatra de Joseph L. Mankiewicz foi nomeado para nove Óscares da Academia, tendo arrecadado quatro $^{207}$. Mas a generalidade dos críticos considera a primeira parte do filme, dedicada à relação da rainha com César, francamente superior à segunda, que se centra na paixão de António. Esta divisão chegou a sugerir ao realizador a autonomizaçáo de cada uma das partes em dois filmes distintos, proposta que, no entanto, a Fox rejeitou e não se concretizou ${ }^{208}$. De certo modo, a opção tomada funde numa única obra as tradiçôes associadas às mais famosas peças romanas de William Shakespeare: Julius Caesar e Antony and Cleopatra.

No ano seguinte, em 1964, Cleópatra foi a personagem escolhida para a sátira na conhecida série

${ }^{206}$ Plutarco, António 60.1.

${ }^{207} \mathrm{O}$ filme recebeu os prémios pela fotografia, direcção artística, guarda-roupa e efeitos especiais visuais.

${ }^{208}$ Solomon (2001) 69. Os filmes seriam: Caesar and Cleopatra e Antony and Cleopatra. 
britânica Carry on... O argumento deste Carry on Cleópatra, dirigido por Gerald Thomas, é sobretudo uma paródia eficaz do filme de Mankiewicz. A companhia constituída pelos actores do filme era formada por um elenco fixo, o que, à partida, garantia o riso, pois cada um dos intérpretes, apoiado por um público fiel, assume a personagem histórica respectiva, atribuindo-lhe os tiques próprios das suas representações. Assim é com o sotaque cockney de Marco António (Sidney James), a atitude histérica de Júlio César (Kenneth Williams) ou com a esganiçada mas fabulosa Calpúrnia (Joan Sims), cuja aparição no ecrã delicia todos os que a ela assistem, ao vê-la com um apelativo e demasiado evidente laço no topo da nuca. Cleópatra (Amanda Barrie), que surge sempre com os olhos esbugalhados, alimenta o estereótipo do banho de leite, atribuído a várias figuras da Antiguidade, entre as quais a Popeia Sabina (Claudette Colbert) de DeMille, que dele usufrui no filme The Sign of the Cross (1932). Em tom de paródia, esta Cleópatra passa praticamente todo o filme imersa num banho lácteo. Pela bizarria humorística, este motivo equivale ao das "pérolas dissolvidas em vinagre» da Cleópatra de Goscinny e Uderzo. O tom geral do filme é, aliás, o de "Astérix", que se evidencia pelos trocadilhos feitos à base da Britânia, que César nunca chegou a invadir. Não deixa de ser surpreendente e cómica pela auto-crítica que implica, à boa maneira britânica, a representação daquela regiáo como vivendo ainda na "Idade da Pedra", quando em Roma já mandava César e no Egipto reinava Cleópatra. 
Em 1973, o tema ressurgiu no cinema, desta vez pela mão de Charlton Heston, o grande veterano dos epics. Neste Antony and Cleopatra, Heston interpreta a personagem titular, ao lado de Hildegard Neil (Cleópatra), Carmen Sevilla (Octávia) e John Castle (Octávio). Esta versão, que vem na sequência da que S. Burge fez da tragédia Julius Caesar em 1970, com o mesmo Charlton Heston a interpretar Marco António, consiste numa transposição assumida para cinema da peça de Shakespeare, Antony and Cleopatra, escrita entre 1603 e $1607^{209}$. Sendo quase toda baseada em Plutarco, a tragédia do bardo inglês transfere para o palco e depois para a tela as marcas do biógrafo de Queroneia. Heston é a estrela do filme, conseguindo um Marco António interiormente sofrido e ferido pela paixáo, apesar de pouco convincente nas cenas em que deveria mostrar submissão passional à rainha. Como se Heston tivesse receio de manchar a sua reputação de herói másculo e viril. Ainda assim, não deixa de ser cativante o momento em que Cleópatra póe sobre António as suas jóias de mulher, oferecendo-lhe desse modo uma aura feminina, tal como Hércules perante Ônfale, muito ao jeito de Plutarco ${ }^{210}$. Já Neil, foi um erro de casting. É mesmo surpreendente que a sua interpretaçáo chegue a ser ofuscada pela da actriz que interpreta Carmiana (Jane Lapotaire). Em contrapartida, é de toda a justiça uma referência especial a Lapotaire, que recria a aia e que veio a ser uma das mais extraordinárias Cleópatras

${ }^{209}$ Recordamos que em 1950 havia integrado o elenco de Julius Caesar de David Bradley.

${ }^{210}$ Plutarco, António 90.4. 
no teatro e no ecrã, como mostra a encenaçáo da peça de Shakespeare feita pela BBC em 1981. Igualmente assinalável é a interpretação de Emiliano Redondo, no papel do eunuco da rainha ${ }^{211}$.

Nesta produção, rodada em Espanha, a teatralidade alterna com cenas mais cinematográficas, como a que recria a batalha de Áccio, de modo a obter um equilíbrio para o ambiente de cinema. Uma palavra ainda para os cenários e guarda-roupa. Heston optou por recriar os ambientes antigos e rejeitar a cenografia de tipo renascentista, comum nas adaptaçóes shakespeareanas e que revivera na produção de 70, ainda que tivesse de contentar-se com os restos de The Fall of the Roman Empire (1964) ${ }^{212}$. Não deixa de nos surpreender o momento, porém, em que Charlton Heston aparece quase integralmente nu no ecrã, uma opção ousada e pouco usual para a encenação shakespeareana, e menos ainda para o establishment cinematográfico norte-americano da época. Apesar da dignidade das origens, este filme acabou por ser incluído nas listas de pepla das décadas de 60 e 70.

Em 1999, Memoirs of Cleopatra, um romance de Margaret George, foi adaptado para televisão, com realização de Franc Roddam. $\mathrm{O}$ melhor desta adaptação está em Enrico Sabbatini, autor credenciado dos figurinos. Cenários e guarda-roupa passam no exame. Mas as interpretaçóes e os diálogos ficam aquém do esperado. Nem o britânico Rupert Graves escapa no papel de Octávio. A actriz titular, a sul-americana Leonor Varela,

211 Também notada por De España (1998) 254.

${ }^{212}$ De España (1998) 254. De igual modo, a cena de Áccio foi feita com recurso a partes de Ben-Hur, de 1959. 
foi um erro de escolha. A opção denuncia um estereótipo cultural moderno tipicamente norte-americano que tende a associar o Outro mediterrâneo a tipos sul-americanos, o que náo deixa de nos «soar» ridículo, pois resulta numa macedónia com ar de mexicana ou porto-riquenha, senhora de uma incomum faceta filantrópica ${ }^{213}$. De Plutarco, lá subsistem os episódios do tapete, da barca em Tarso, a identificação de António com Dioniso, Áccio e o motivo final do suicídio. Os temas shakespeareanos estão também presentes, bem como a tradiçáo da aia negra e da caucasiana ${ }^{214}$ ou o assassinato de César. Igualmente pertinente é a ênfase dada à personagem de Cesarião e à tradição que a tem como filho de Júlio César. Menos ortodoxa é a visão de Cleópatra armada e a combater, evocando talvez o tema próximo-oriental da deusa guerreira... Apesar de tudo, a forma como o filme se desenrola é historicamente verosímil e, a favor desta produção, há ainda o suicídio de António e Cleópatra, que não acontece logo a seguir à batalha de Áccio. O que está de acordo com a narrativa plutarquiana.

Data de 2007 aquela que é talvez a mais original adaptação da vida de Cleópatra VII ao cinema. Também pouco comum é o facto desta adaptação ter sido feita em língua portuguesa, por um realizador brasileiro, Júlio Bressane, que considerou a sua obra «um pequeno filme sobre um grande tema». A fita, porém, foi particularmente mal recebida por alguma da crítica

${ }^{213}$ Sobre estes estereótipos, ver Wyke (2002) 273.

${ }^{214} \mathrm{~A}$ actriz que interpreta o papel de Carmiana (Indra Ove) não é caucasiana. 
brasileira, para quem, o motivo plutarquiano passou ao lado e que motivou adjectivaçóes como "perturbador, difícil, cansativo, devasso e intolerável $»^{215}$. Talvez por isso também lhe tenham chamado "filme-esfinge». $\mathrm{Na}$ verdade, não se trata de um filme épico, no qual se vejam grandes cenas como a da entrada triunfal em Roma, a da chegada a Tarso ou a da batalha de Áccio. Longe disso. $\mathrm{O}$ argumento deste Cleópatra centra-se nas palavras e na plasticidade onírica, quase surreal, das imagens, destacando-se uma marca teatral que se foca nos actores e na maneira de dizer e que domina toda a produção. Decerto, uma herança da tragédia isabelina.

Como afirmou o seu realizador à imprensa local, este filme é sobretudo poesia, reencarnada em Cleópatra, e não prosa. Neste quadro, os acontecimentos históricos passam para segundo plano e a vida da rainha transforma-se num mero pretexto ao serviço da mais pura estética cinematográfica. Mas ainda assim, não deixa de ser a relação entre a rainha do Egipto, interpretada pela actriz Alessandra Negrini, com Júlio César (Miguel Falabella) e Marco António (Bruno Garcia) o centro da trama. A sequência em que Cleópatra suga o peito de César foi considerada de mau gosto por alguns mas interpretada por outros como o símbolo da absorção da cultura egípcia por parte de Roma. Mas, se foi essa a intenção, não deveria ser ao contrário? Outra das características que poderá ter desagradado ao público brasileiro foi o facto de, em parte, os actores falarem

${ }^{215}$ Classificações que, na imprensa brasileira, foram atribuídas com outras que consideraram o filme "poético, belo e intenso". 
um português mais próximo do europeu do que do sul-americano. Mas a variedade de pronúncias ouvidas, que vai do português europeu às formas de falar em várias regióes do Brasil, é algo que se sugere intencional, numa evocação da referência plutarquiana acerca do carácter poliglota da rainha. Factor a que os críticos náo estariam obrigados a conhecer, claro, mas a que se junta o desconforto que para eles será ouvir ainda algumas falas em grego clássico.

O filme é rico em símbolos, metáforas, alusões e remissóes que não se compadecem com uma erudição mediana: a concha afrodisíaca em que Cleópatra se senta e domina César (uma transferência do tema que conhecemos em relação a António), a cabeça de Pompeio, o exotismo erótico patente na silhueta itifálica do deus Min, a alusão à polémica pintura de Gustave Courbet, L'origine $d u$ Monde, o trocadilho com a língua latina posto na boca de César («o mundo chama-se mundo porque é imundo»), a semelhança de Falabella com os retratos romanos do século I a.C., o banho de leite que se transforma em sangue, a descrição do modus uiuendi dionisíaco de António e Cleópatra, as alusóes à pintura histórica oitocentista como a que se vê na cena da morte da rainha, entre outros. Estes são elementos que se misturam com a base plutarquiana do enredo, patente nas personagens, como as aias (ambas caucasianas) ou as mulheres de César e António, Calpúrnia e Octávia ${ }^{216}$.

Nos diálogos está presente a percepção do

216 E.g. Plutarco, Catão-Menor 33.7; César 14.8; 63.8-11; 64.4-6; Pompeio 47.10; António 15.1; 31.1-5; 87.3. 
significado do episódio "Cleópatra» na História do Mundo, em particular o processo de fusão cultural entre o Oriente e o Ocidente que ocorreu nos séculos I a.C. e I d.C. O belo e significativo discurso de Cleópatra no momento em que evoca a pintura de Courbet é pura poesia e sintetiza esta ideia com a de erotismo que reencontramos em outras versóes:

Contemple com o seu olhar todo o cosmos, todos os tempos. O desejo é a sede. $\mathrm{O}$ amor é a água. Aqui, a bela flor, a origem de tudo, a fonte, a água da vida... Em mim, só em mim, a polaridade funde-se. Misturada em meu corpo, ordenação grega versus fantasia do Oriente. Lógica versus magia. Matemática versus mitologia. Atenas versus Alexandria. Em meu espírito, essas forças são uma coisa só. Sou Alexandria e sou Atenas... Sou Cleópatra, sou Alexandria, sou Atenas.

A aparição mais recente de Cleópatra no ecrã foi através da já mencionada série Rome, produzida pelo canal $\mathrm{HBO}^{217}$. Esta Cleópatra, interpretada pela actriz britânica Lyndsey Marshal, continua alguns dos temas já antes tratados por actrizes e realizadores, mas foge também a alguns estereótipos. Esta não é uma Cleópatra de rosto angelical ou sequer reptilíneo. Pelo contrário, a figura que encontramos aqui surge controlada por estupefacientes $^{218}$, num corpo que está longe de ser o

${ }^{217}$ Em rigor, trata-se de uma aparição em televisão. Mas não deixa de ser numa forma artística ligada à Sétima Arte. A rainha é introduzida no episódio 8 da primeira série.

218 Como nota Daugherty (2008) 145, este pormenor da composição da Cleópatra de Marshal deverá basear-se na Cleópatra 
modelo de sensualidade a que nos habituámos a ver associado à figura da última rainha do Egipto lágida. A beleza não é de todo um atributo desta composição, pelo menos na perspectiva estereotipada, o que poderá coincidir com o que Plutarco afirma relativamente à macedónia. $\mathrm{O}$ biógrafo considerava que a beleza não era um atributo da rainha, mas sim as suas qualidades enquanto mulher inteligente, sagaz, culta, poliglota e audaz $^{219}$. Os argumentistas da série parecem ter estado atentos a esse pormenor ${ }^{220}$. Por outro lado, emergem outras variantes, como o facto de Cleópatra não ser levada a César num tapete mas sim dentro de um saco ou de o fiel Apolodoro ser substituído por Voreno, uma das personagens centrais, ainda que ficcional, da série. Igualmente interessante é a opção de fundir elementos macedónicos com egípcios no set em que se passam as cenas com esta Cleópatra. A intenção terá sido proporcionar ao espectador uma estética grotesca que sugerisse um Egipto decadente e já não apoteótico como havia sido o dos tempos faraónicos. O que, quanto a nós, parece ter resultado com eficácia. Quanto à figura de Carmiana (Kathryn Hunter), que uma vez mais se destaca sobre a de Iras, parece assentar sobretudos na Ftatatita de Shaw e não em qualquer eventual

de Shakespeare, por um lado, onde a rainha se confessa adepta de bebidas alucinogéneas (Shakespeare, Antony and Cleopatra 1.5.4-7), e nas fontes antigas por outro, visto que os autores a associam à feitiçaria, o que poderá ser indício das drogas. Sobre esta questão, ver Rodrigues (1999) e (2002). Mas a modernidade do tema é evidente

${ }^{219}$ E.g. Plutarco, César 49.

${ }^{220}$ Daugherty (1998) 144. 
referência plutarquiana ${ }^{221}$. Mas será pouco credível que a personagem interpretada por Kathryn Hunter tivesse já a idade que ali aparenta.

A Cleópatra de Rome enquadra-se no leitmotiv que tem orientado as mais recentes leituras cinematográficas da rainha: a sexualidade/sensualidade. De facto, é essa característica que parece atrair os públicos contemporâneos e que por isso orientou as interpretaçóes da personagem em filmes como Cleopatra (1999), Julius Caesar (2002) e Imperium: Augustus (2003) ${ }^{222}$. Até mesmo a Cleópatra recriada pela belíssima Monica Bellucci em Astérix et Obélix: Mission Cléopâtre (2002) segue essa orientação, apesar de o argumento provir de uma conhecida BD que inclui audiência infanto-juvenil entre o seu público. Significa isso que a perspectiva da rainha sedutora, igualmente fornecida por Plutarco, tem triunfado no cinema. Como aconteceu com outras figuras do seu tempo, a personagem chegou mesmo à pornografia, viu e venceu... ${ }^{223}$. O mesmo se verificou também com o seu parceiro António, que inclusivamente fez incursóes em todo o tipo de cinema underground

${ }^{221}$ Influências da peça de Shaw e da respectiva adaptação ao cinema feita por Pascal podem igualmente ser detectadas no guardaroupa escolhido para Rome, como nota Daugherty (2008) 146.

${ }^{222}$ Filmes em que a rainha é interpretada por Leonor Varela, Samuela Sardo e Anna Valle, respectivamente. Wyke (2002) 198-199 salientou esse aspecto sedutor da rainha sobre antigos e modernos. Diz a autora: "Cleopatra VII appears to have seduced scholars as well as Romans», aos quais acrescentamos os cineastas. Ver ainda Cyrino (2005) 154, que salienta o facto de, ao contrário de outros épicos, ou mesmo pepla, este filme ignorar por completo o físico masculino, apostando no feminino.

${ }^{223}$ Daugherty (2008) 149; Nisbet (2009). 
de públicos alternativos ${ }^{224}$. O par plutarquiano acabou assim por se transformar num casal de heróis da cultura $p o p$ no sentido mais lato da palavra.

\section{Conclusóes}

Leónidas é o exemplo de como a presença do tratadista de Queroneia pode estar disseminada por várias produçóes cinematográficas, sem que as personagens desses filmes tenham necessariamente dado origem a uma biografia conhecida da autoria de Plutarco. E há outros textos e outros nomes a ter em conta. Há personagens plutarquianas, que poderíamos designar como

${ }^{224}$ Títulos sugestivos como The Notorious Cleopatra (1970, de P. Perry Jr.), Sogni erotici di Cleopatra (1985, de R. Silvestro), Antonio e Cleopatra (1996, de J. D’Amato, publicitado como «History's hottest couple in an orgy of wine, women and debauchery»); Cleopatra (2003, de A. Adamo), Cleopatra II - Legend of Eros (2004, de A. Adamo), Os Prazeres de Cleópatra (2004, do brasileiro P. Aquirre), e um Marc Anthony (2003, de S. Brogi), no domínio da pornografia gay, dão conta do êxito desta fórmula na cinematografia do género. Encontra-se inclusivamente uma "actriz» da especialidade cujo nome é... "Cleopatra»! E até o cinema de animação inclui este tema, em Kureopatora, filme japonês de O. Tezuka e E. Yamamoto (1970). Sobre estas problemáticas, ver Daugherty (2008) 150; Nisbet (2009). São várias as personagens da Antiguidade, como Espártaco, Calígula, Messalina, Nero, Afrodite, que servem de pretexto para produçóes deste tipo de indústria, traduzindo um género específico de popularidade do tema entre as massas, associado a uma imagem manipulada do Mundo Antigo. Este aproveitamento dos temas romanos pela pornografia contemporânea traduz um fenómeno curioso da História das Mentalidades, que associa a Roma Antiga a esses contextos menos ortodoxos. Nisbet refere-se ao conceito de "pornotopia», como «um conjunto de práticas entendidas como as ideais no domínio da sexualidade e da pornografia» (p. 150). Mas terá Plutarco, em última instância o motivador das temáticas, sido efectivamente lido pelos autores destes argumentos? 
«secundárias», que aparecem destacadas em variadas produçóes e filmes. Leónidas é um desses exemplos. Tal como Cleópatra. Neste estudo citámos também Múcio Cévola, mencionado na Vida de Publícola e a quem foi dedicado um filme em $1964^{225}$. Há ainda o caso de Aníbal (Victor Mature), figura tutelar de Annibale, filme de 1959, cuja acção se baseia em Tito Lívio mas também na Vida de Fábio Máximo, carácter que integra também o elenco das personagens (interpretado por Gabriele Ferzetti) ${ }^{226}$. Em contrapartida, outras figuras foram alvo de maior atenção por parte de Plutarco, mas o cinema contemporâneo apenas as secundarizou, não lhes reconhecendo suficiente interesse metanarrativo, como por exemplo Otáo, a quem o Beócio dedicou uma biografia e que aparece quase como mero carácter de apoio em Poppea, una prostituta al servizio dell'impero de Alfonso Brescia-Müller (1972), onde é interpretado por Don Backy ${ }^{227}$. E os exemplos poderiam multiplicar-se.

Por conseguinte, o método para estudar a presença de Plutarco no cinema deve ter em consideração estas variantes e especificidades. $\mathrm{O}$ que propomos com esta investigação é essencialmente uma introdução a um

225 Plutarco, Publícola 17.

226 Caso semelhante acontece com Scipione l'Africano de C. Gallone (1937), que tem a particularidade de ter sido rodado no período mussoliniano. Ver Attolini (1991) 449-453.

${ }^{227}$ Cf. Plutarco, Otão. Otão aparece de forma fugaz em A.D. - Anno Domini de S. Cooper (1985) e é a personagem central da adaptação ao cinema de Othon, peça de Corneille baseada em Plutarco, feita em 1969 por Jean-Marie Straub e Danièle Huillet, com Adriano Aprà no papel principal. O título original desta produção é Les yeux ne veulent pas en tout temps se fermer, ou Peutêtre qu'un jour Rome se permettra de choisir à son tour. 
tema que tem mais potencialidades de pesquisa. Para já, avançamos com o levantamento e conspecto das fontes disponíveis para análise, e com a enunciação e perspectivação de problemáticas a serem equacionadas. Os últimos anos têm assistido a um boom significativo de trabalhos acerca da Antiguidade no cinema, em particular da Antiguidade Clássica. Concretizar essa mesma tarefa a partir das fontes antigas utilizadas, no sentido de averiguar as metamorfoses ou continuidades das culturas antigas na contemporaneidade é, quanto a nós, um projecto que tem ainda frutos a dar. Os resultados permitem-nos perceber as formas como o Mundo Antigo tem vindo a ser entendido, recepcionado, reutilizado e manipulado nos nossos dias e em que sentidos seguem essas releituras. No caso do cinema, este aspecto é particularmente pertinente. Não esqueçamos que houve e continua a haver milhóes de espectadores em todo o mundo para estes filmes e que nunca a Antiguidade chegou a tanta gente ao mesmo tempo ${ }^{228}$. Mas a mensagem segue filtrada pelo olhar moderno que pretende que a mesma seja entendida a partir de um determinado ângulo. É pois importante desmontar e reorganizar os elementos em jogo. Foi essa avaliação e desmontagem que aqui tentámos fazer, olhando para algum do cinema de tema antigo a partir dos textos de Plutarco.

A popularidade do Beócio entre os argumentistas e autores de guióes para cinema tem uma razão de ser, apesar de ter sido já afirmado que «screenwriters almost

${ }^{228}$ Cf. Winkler (2001) 83. 
never read Plutarch $»^{229}$. Mas grande parte do essencial da intriga que surge no enredo destes filmes, quer no epic film, mais nobre, quer no peplum, mais popular, está já presente nas Vitae de Plutarco. Os guionistas apenas têm que adaptá-la. É isso que em grande medida justifica o êxito de Plutarco no cinema. Os motivos romanescos, trágicos e épicos que consubstanciam as histórias fílmicas estão já presentes na obra do tratadista. Em alguns casos, a semente foi lançada a partir da própria matéria histórica. Noutros resulta da elaboração do autor grego e da sua concepção de «biografia». Histórias de vida e dramas familiares - Plutarco dá uma particular atenção aos pormenores genealógicos e aos conflitos familiares vividos pelos seus heróis -, lutas de afirmação pelo poder ou pela simples existência, viagens e roteiros formativos, combates ideológicos fazem parte da longa lista de elementos que definem o herói plutarquiano. O mesmo se diga acerca dos seus dilemas morais, psicológicos e afectivos. Com a adjuvante de Plutarco ser rico na montagem de "grandes cenas»" ${ }^{230}$. Ora estas são matérias apelativas para as audiências hodiernas e há que ter presente que a nossa cultura ocidental radica na do mundo de Plutarco. Assim, se o percurso biográfico fornece matéria para o biopics e para o epic film, aventuras e registos romanescos revelaram-se essenciais para a composição do peplum.

A utilização do cinema como fonte histórica é complexa e problemática. Mas não deixa de ser

${ }^{229}$ Daugherty (2008) 144.

${ }^{230}$ Cf. Frazier (1992), (1996). 
pertinente. Tanto mais que vivemos num tempo em que a cultura popular e a educação de massas faz-se, em grande medida, à base do cinema e de formas de arte afins. Para muitos, um filme de temática histórica será o que de mais parecido conhecerão com um ensaio sobre História. Faz sentido por isso incluir aqui o conceito de «historiophoty», usado por $\mathrm{H}$. White, que mantivemos subjacente ao longo da nossa pesquisa e exposição e que tentamos/propomos traduzir por "historiofotia», i.e., a «representação da História e do que sobre ela pensamos através da visualização da imagem e do discurso fílmico» ${ }^{231}$.

Enquanto fonte e objecto de análise, o cinema de tema histórico implica uma postura dupla. Trata-se de uma forma de aproveitamento e divulgação de factos passados, mas também da afirmação de uma perspectiva e de uma tomada de posição por parte de quem olha para esses mesmo factos, não raramente entendidos como metáforas dos tempos vividos no presente. Neste sentido, o cinema de tema histórico tanto é matéria do domínio da história do objecto filmado como do da história de quem filma. No caso do cinema que trata da Antiguidade Clássica, que é um fenómeno com pouco mais de um século, os filmes produzidos são tanto objecto da História e Culturas Antigas quanto da História e Cultura Contemporâneas, porque o cinema representa sempre o passado em função da mentalidade do presente. Uma reinterpretação do passado em função da mentalidade

${ }^{231}$ White (1988). 
contemporânea $^{232}$. É no espaço que medeia cada uma destas fronteiras que embatem as críticas em torno do rigor histórico neste tipo de produçôes. Mas esse pode ser de facto um problema relativo para o historiador, que procura vestígios para organizar a sua ciência em toda a matéria que analisa. A aplicação do «rigor histórico» num filme é uma questão objectiva. Mas a opção por não ser «rigoroso» é igualmente útil e pertinente para o investigador. É por isso que afirmamos que os filmes sobre Júlio César dizem tanto ou mais sobre quem os concebeu e produziu do que acerca do próprio dictator.

Ao mesmo tempo, poder-se-á alegar que o objectivo do realizador e dos produtores é entreter as suas audiências, divertir o espectador, através da identificação das personagens e dos ambientes com o público, e não ministrar uma lição de História. Como é sabido, este princípio é hoje utilizado de forma recorrente. Um filme não é um manual de História e tem como objectivo principal divertir o seu público, que por seu lado deseja rever-se naquilo a que assiste. Há que não esquecê-lo. Por vezes, o resultado a que um filme equivale depende de vários membros da equipa que o concretiza (argumento, cinematografia, guarda-roupa, cenografia, som, produção, etc.) e náo apenas do seu realizador. Mas por norma é a este que cabe a decisão final, pelo que é ao director que atribuímos as opçóes tomadas, embora conscientes de tudo o que está envolvido ${ }^{233}$. Estas perspectivas foram também por nós consideradas. 
O facto de estas leituras terem vindo a revelar-se sobretudo anglo-saxónicas deriva de a indústria cinematográfica ser maioritariamente originária desse contexto. Essa é também a razão pela qual a cultura anglófona ter vindo a ser um motor cultural importante do Ocidente no último século, tendo por isso responsabilidades acrescidas no quadro da recepção e divulgação das heranças culturais de que Plutarco e a sua obra fazem parte. Já o êxito do peplum, que é um fenómeno europeu, sobretudo italiano, justifica-se pela conjuntura em que apareceu ${ }^{234}$.

Com estas questóes presentes, torna-se menos difícil compreender a razão pela qual o cinema tem reinventado as histórias dos homens e dos acontecimentos narrados por Plutarco. As narrativas modernas e pós-modernas nem sempre coincidem com o que o Queronense escreveu, nem sempre seguem a outline concebida no século II d. C., preferindo tomar decisóes diferentes e optar por outros caminhos. De todas as figuras biografadas, os séculos XX e XXI têm mostrado preferência e apetência por generais e conquistadores, como Alexandre e César. De certa forma, a História Positivista ressuscitou neste novo medium de transmitir a memória. Mas até no cinema a perspectiva sobre eles tem variado ao longo das décadas, dependendo de conjunturas e interesses sócio-político-culturais. É isso que justifica as constantes revisitaçóes destas temáticas pelos cineastas e os vários níveis de leitura envolvidos. Mas o importante a destacar é que

${ }^{234}$ Sobre o caso italiano, ver Attolini (1991). 
seja qual for a perspectiva, épica ou trágica, colectiva ou intimista, familiar ou psicológica, erudita ou popular, é sempre à primeira fonte que se vai beber, é lá que se colhe o tema de base: a Plutarco. Mesmo quando acontece haver um intermediário da craveira de Shakespeare. Assim acontece com as personalidades supracitadas, mas também com Coriolano ou até mesmo Espártaco. As variantes não cessam e até o universo alternativo da pornografia foi atingido pela onda plutarquiana. $\mathrm{O}$ caso mais sintomático de todos, porém, é sem dúvida alguma o de Cleópatra. Apesar de não ser uma «biografada» de excelência de Plutarco, é, a par com Júlio César, a figura plutarquiana que mais leituras tem suscitado neste domínio ${ }^{235}$. E avistam-se mais para breve...

No final, balanço feito, talvez cineastas, realizadores, argumentistas e produtores contemporâneos simplesmente sigam à risca as liçóes do mestre, ainda que não o leiam com a atenção merecida. Devolvemos pois a palavra a Plutarco e ao que o biógrafo de Queroneia escreveu no início da Vida de Alexandre, em defesa da liberdade do autor/artista. A generosidade de Plutarco e da sua obra permite que seja o próprio a sair em defesa de todos os que o glosam, oferecendo-lhes o mais eficaz dos argumentos:

Tendo-nos proposto a escrever neste livro a vida do rei Alexandre e a de César, que derrotou Pompeio, dada a grande quantidade de façanhas de um e de outro, advertimos o leitor de apenas um pormenor e fazemos-lhe um único

${ }^{235} \mathrm{O}$ mesmo acontece na pintura. Cf. o texto de P. S. Rodrigues neste volume. 
pedido: não nos recriminem ou censurem pelo facto de não sermos exaustivos, ou por não sermos demasiado prolixos em cada um dos aspectos mais conhecidos, ou porque eliminámos ou suprimimos alguns aspectos. É que não escrevemos sobre a História mas sobre vidas. ${ }^{236}$

${ }^{236}$ Plutarco, Alexandre 1. 


\section{BibLIOGRAFIA}

Aknin, L. (1998), "Divine Cléopâtre”» in C. Aziza, dir., Lepéplum: l'Antiquitéau cinema. Coubervoie, Éditions Corlet, 21-25.

Alonso, J. J. et al. (2008), La Antigua Roma en el Cine. Madrid, T\&B Editores.

__ et al. (2008a), "Morituri te salutant. Un hombre de izquierdas (y su hijo) - Espartaco. El hijo de Espartaco» in La Antigua Roma en el Cine. Madrid, T\&B Editores, 77-107.

__ et al. (2008b), «Sudauit et alsit. Con falditas y a lo loco» in La Antigua Roma en el Cine. Madrid, T\&B Editores, 11-33.

Attolini, V. (1991)., "Il Cinema» in G. Cavallo, P. Fedeli, A. Giardina, dir., Lo Spazio letterario di Roma antica IV - L'attualizzazione del testo. Roma, Salerno Editrice, 431493.

Aulotte, R. (1965), Amyot et Plutarque: la tradition des Moralia au XVI siècle. Genève, Droz.

Azıza, C. (1998), Le péplum: l'Antiquité au cinema. Coubervoie, Éditions Corlet.

Barthes, R. (1957), Mitologias. Lisboa, Ediçôes 70.

BauzÁ, H. F. (2002), "Humanismo y Acciones en las Vidas de Plutarco» in Plutarco. Educador da Europa. Actas do Congresso. Porto, Fundação Eng. 
António de Almeida, 181-196.

Beall, H. S. (1960), «Historical Fiction on Classical Themes», CW 54/1, 8-12.

Bertini, F., int. (1997), Il mito Classico e il Cinema. Genova, D.AR.FI.CL.ET. «F. Della Corte».

Bourget, J. L. (1992), L'Histoire au cinema. Le passé retrouvé. Paris, Gallimard.

Buller, J. L. (1992), Historical Films in the Latin classroom. Oxford/Ohio/Miami, The American Classical League.

Bundrick, S. D. (2009), "Dionysian Themes and Imagery in Oliver Stone's Alexander», Helios 36/1, 81-96.

Cano, P. L. (1984a), «Roma y el Cine», Film Guía 5, 7-10.

__ (1984), «La historia de Roma vista por el cine. Filmografia», Faventia 6/1, 163-166.

Cano, P. L., Llorente, J. (1985), Espectacle, amor $i$ martiris al cinema de romans. Tarragona, Promociones y Publicaciones Universitarias.

Carmona, L. M. (2006), Los 100 Grandes Personajes Históricos en el Cine. Madrid, Cacitel.

Cartledge, P., Greenland, F. R. (2010), Responses to Oliver Stone's Alexander. Film, History and 
Cultural Studies. Madison, The University of Wisconsin Press.

Cary, J. (1974), Spectacular! The Story of Epic Films. London, Hamlyn.

Clauss, J. J. (1996), «A Course on Classical Mythology in Film», CJ 91/3, 287-295.

Collognat, A. (1998), "Ab Vrbe condita... Du mythe au l'écran: la naissance de Rome» in C. Aziza, dir., Le péplum: l'Antiquité au cinema. Coubervoie, Éditions Corlet, 63-69.

Curl, J. S. (2005), The Egyptian Revival. Ancient Egypt as the Inspiration for Design Motifs in the West. London/New York, Routledge.

Custen, G. F. (1992), Bio/Pics. How Hollywood constructed Public History. New Brunswick, Rutgers University Press.

Cyrino, M. S. (2005), Big Screen Rome. Oxford, Blackwell Publishing.

Cyrino, M. S. (2010), «Fortune favors the Blond: Colin Farrell in Alexander in P. Cartledge, F. R. Greenland, eds., Responses to Oliver Stone's Alexander. Film, History and Cultural Studies. Madison, The University of Wisconsin Press, 168-182.

ed. (2008), Rome. Season One - History makes Television. Oxford, Blackwell Publishing. 
Daugherty, G. N. (2008), "Her First Roman: A Cleopatra for Rome» in M. S. Cyrino ed., Rome. Season One: History makes Television. Malden/Oxford, Blackwell Publishing, 141-152.

De España, R. (1998), El Peplum. La Antigüedad en el Cine. Barcelona, Glénat.

Dias, P. B. (2007), «300, filme de Zack Snyder, Kurt Johnstad e Michael Gordon, 2007», BEC 47, 173-176.

Duplá, A., Iriarte, A., eds. (1990), El Cine y el Mundo Antiguo. Bilbao, Universidad del País Vasco.

Elley, D. (1984), The Epic Film: Myth and History. London, Routledge.

Fatás, G. (1990), «Una visión de la crisis de la Republica Romana a traves del cine» in A. Duplá, A. Iriarte eds., El Cine y el Mundo Antiguo, Bilbao, Universidad del País Vasco, 15-37.

—_ (1999), «Espartaco» in J. Uróz, ed., Historia y Cine. Alicante, Publicaciones de la Universidad de Alicante, 127-162.

Frazier, F. (1992), "Contribution à l'étude de la composition des "Vies" DePlutarque: l'élaboration des grandes scènes», $A N R W$ II.33.6, 4488-4535. 
—_ (1996), Histoire et Morale dans les Vies parallèles de Plutarque. Paris, Les Belles Lettres.

Frías Castillejo, C. (2007), «Espartaco y la lucha de clases en Hollywood de McCarthy", Quaderns de Cine 1, 61-68.

Futrell, A. (2001), «Seeing Red. Spartacus as Domestic Economist» in S. R. Joshel, M. Malamud, D. T. McGuire, eds., Imperial Projections. Ancient Rome in Modern Popular Culture. Baltimore/ London, The Johns Hopkins University Press, 77-118.

Galinsky, K. (1996), Augustan Culture. An Interpretive Introduction. Princeton, University Press.

García Fuentes, M. C. (1992), «Filmografía mítica en el peplum», Cuadernos de Filología Clásica. Estudios Latinos 3, 301-311.

García Gual, C. (1995), La Antigüedad Novelada. Las novelas históricas sobre el mundo griego y romano. Barcelona, Editorial Anagrama.

García Moreno, L. A. (1999), "Cleopatra. El film de Joseph L. Mankiewicz» in J. Uróz, ed., Historia y Cine. Alicante, Publicaciones de la Universidad de Alicante, 163-182.

Günsberg, M. (2005), «Heroic Bodies: the Cult of Masculinity in the Peplum» in Italian Cinema. Gender and Genre. New York, Palgrave MacMillan, 97-132. 
Hamer, M. (1998), William Shakespeare's Julius Caesar. Plymouth, Northcote House Publishers.

__ (2002), "The Myth of Cleopatra since the Renaissance» in S. Walker, P. Higgs eds., Cleopatra of Egypt. From History to Myth. London, The British Museum Press, 302-311.

Hark, I. R. (1993), "Animals or Romans. Looking at Masculinity in Spartacus» in S. Cohan, I. R. Hark, eds., Screening the Male. Exploring masculinities in Hollywood Cinema. London/New York, Routledge, 151-172.

Hughes-Hallett, L. (1990), Cleopatra. Histories, Dreams and Distortions. London, Pimlico.

Hughes-Warrington, M. (2007), History goes to the Movies. Studying History on Film. London/New York, Routledge.

Humphreys, A. (1984), "Introduction» in The Oxford Shakespeare. Julius Caesar. Oxford, University Press, 1-91.

Joshel, S. R., Malamud, M., McGuire, D. T., eds. (2001), Imperial Projections. Ancient Rome in Modern Popular Culture. Baltimore/London, The Johns Hopkins University Press.

KorenjaK, M., Töchterle, K. Hgg. (2002), Altertumswissenschaftler im Kino, oder: Quo uadis philologia? Innsbruck, Studien Verlag. 
LACY, P. de (1952), «Biography and Tragedy in Plutarch», AJPh 73/2, 159-171.

Lagny, M. (1992), "Popular taste: the peplum» in R. Dyer, G. Vincendeau, eds., Popular European Cinema. London/New York, Routledge, 163-180.

Lane Fox, R. (2004), The Making of Alexander. The official guide to the Epic Film Alexander, with a foreword by director Oliver Stone. London, R and L.

_- (2010), «Alexander on Stage: a critical appraisal of Rattigan's Adventure Story" in P. Cartledge, F. R. Greenland, eds., Responses to Oliver Stone's Alexander. Film, History and Cultural Studies. Madison, The University of Wisconsin Press, 5591.

Lane, J. F. (1977), "The decline (and Fall?) of he Roman Film Empire», Films and Filming 23/6, 16-19.

Lapeña Marchena, O. (2008), «El peplum y la construcción de la memoria», Quaderns de Cine 3, 105-112.

Lillo Redonet, F. (1994), El cine de romanos y su aplicación didáctica. Madrid, Ediciones Clásicas.

Lillo Redonet, F. (1997), El cine de tema griego y su aplicación didáctica. Madrid, Ediciones Clásicas. 
Loureiro, J. D. (2007), «Elmo, escudo e lança. O filme 300 de Zack Snyder», BEC 47, 177-184.

MacKinnon, K. (1986), Greek Tragedy into Film. Rutherford / Madison / Teaneck, Fairleigh Dickinson University Press.

Malamud, M. (2008), «Swords-and-Scandals: Hollywood's Rome during the Great Depression", Arethusa 41, 157-183.

-_ (2009), Ancient Rome and Modern America, Oxford, WileyBlackwell.

Martín Rodríguez, A. M. (2007), «Plutarco y el Cine. Los peligros de la imitación automática de los modelos clásicos en Siete Novias para Siete Hermanos» in J. M. Nieto Ibáńez, R. López López, eds., El Amor en Plutarco. León, Universidad de León, 631-638.

Molina Vidal, J. (2007), "Cleòpatra, l'últim filtre. Deconstrucció d'un personatge historic», Quaderns de Cine 1, 47-59.

Moliterno, G. (2008), Historical Dictionary of Italian Cinema. Toronto, The Scarecrow Press.

Momigliano, A. (1993), The Development of Greek Biography. Harvard, University Press.

Monterde, J. E, Selva Masoliver, M., Solà Arguimbau, A. (2001), La representación cinematográfica de la historia. Madrid, Akal. 
Murray, G. N. (2007), «Zack Snyder, Frank Miller and Herodotus: three takes on the 300 Spartans», Akroterion 52, 11-35.

Nikoloutsos, K. P. (2008), "The Alexander Bromance: Male Desire and Gender Fluidity in Oliver Stone's Historical Epic», Helios 35/2, 223-251.

Nisbet, G. (2008), Ancient Greece in Film and Popular Culture. Bristol, Phoenix Press.

Nisbet, G. (2009), “Dickus Maximus”: Rome as pornotopia» in D. Lowe, K. Shahabudin, eds., Classics for All: Reworking Antiquity in Mass Culture. Cambridge, Scholars Press, 150-171.

Parker, K. (2000), William Shakespeare's Antony and Cleopatra. Plymouth, Northcote House Publishers.

PARker, R. B. (1982), "Introduction» in The Oxford Shakespeare. Coriolanus. Oxford, University Press, 1-148.

Peers, M. P. (2010), Brothers are better than Sisters: a Semiotic, Feminist Analysis of HBO's Rome. Las Vegas, University of Nevada.

Petrovic, I. (2008), «Plutarch and Stone's Alexander: Fortuna et Virtus» in M. G. Morcillo, I. Berti, eds., Hellas on Screen. Cinematic Receptions of Ancient History, Literature and Myth. Stuttgart, Franz Stein Verlag, 163-184. 
Platt, V. (2010), «Viewing the Past: Cinematic Exegesis in the Cavern of Macedon» in P. Cartledge, F. R. Greenland, eds., Responses to Oliver Stone's Alexander. Film, History and Cultural Studies. Madison, The University of Wisconsin Press, 285-304.

Pomeroy, A. J. (2008), Then it was destroyed by the Volcano». The Ancient World in Film and on Television. London, Duckworth.

Ragalie, M. (2007), «Sex and Scandal with Sword and Sandals: a Study of the Female Characters in HBO's Rome», SMAC 1/1, 1-19.

Reames, J. (2010), "The Cult of Hephaestion» in P. Cartledge, F. R. Greenland, eds., Responses to Oliver Stone's Alexander. Film, History and Cultural Studies. Madison, The University of Wisconsin Press, 183-216.

Reinhold, M. (1984), Classica Americana. The Greek and Roman Heritage in the United States. Detroit, Wayne State University Press.

Rodrigues, N. S. (1999), "O Judeu e a Egípcia: o retrato de Cleópatra em Flávio Josefo», Polis. Revista de Ideas y Formas Políticas de la Antigüedad Clásica 11, 217259.

(1999), "Roma e o Cinema, para uma nova abordagem da História da Antiguidade», Classica. Boletim de Pedagogia e Cultura 23, 113-118. 
(2002), «Plutarco, historiador dos Lágidas: o caso de Cleópatra VII Filopator» in J. Ribeiro Ferreira, coord., Actas do Congresso "Plutarco educador da Europa». Porto, Fundação Eng. A. Almeida, 127-149.

__ (2005), Mitos e Lendas da Roma Antiga. Lisboa, Livros e Livros.

__ (2007), «Plutarco e os "Amores Proibidos"» in J. Ma. Nieto Ibáñez, R. López López, eds., El Amor en Plutarco. León, Universidad de León, 525-541.

___ (2009), «O Batalhão Sagrado de Tebas, uma utopia platónica?» in M. F. Silva, coord., Utopias \& Distopias. Coimbra, Imprensa da Universidade, 107-111.

Russell, D. A. (1973), Plutarch. London, Duckworth.

Sales, J. C. (2009), "Cinema e História Antiga. A propósito do filme Cleopatra (1963) de Joseph Leo Mankiewicz - I parte», Cadmo 19, 131-154.

Salotti, M. (1997), "Note sul cinema mitologico italiano: 1957-1964" in Il mito Classico e il Cinema. Genova, D.AR.FI.CL.ET. «F. Della Corte», 47-57.

SAntos, N. C. (2008), «Ecos de Heródoto e Plutarco no filme 300 de Zack Snyder», BEC 50, 121-124.

Shackford, M. H. (1929), Plutarch in Renaissance 
England with special reference to Shakespeare. Wellesley, Wellesley College.

Shahabudin, K. (2010), "The Appearence of History: Robert Rossen's Alexander the Greats in P. Cartledge, F. R. Greenland, eds., Responses to Oliver Stone's Alexander. Film, History and Cultural Studies. Madison, The University of Wisconsin Press, 92116.

Siarri, N. (1985), "Jules César au cinema», Caesarodunum 20bis, 483-507.

Skinner, M. B. (2010), «Alexander and Ancient Greek Sexuality» in P. Cartledge, F. R. Greenland, eds., Responses to Oliver Stone's Alexander. Film, History and Cultural Studies. Madison, The University of Wisconsin Press, 119-134.

Solomon, J. (1996), "In the Wake of "Cleopatra": The Ancient World in the Cinema since 1963», CJ 91/2, 113-140.

- (2001), The Ancient World in the Cinema. New Haven/London, Yale University Press.

Stonebanks, C. D. (2008), «Spartan Superhunks and Persian Monsters: responding to truth and identity as determined by Hollywood», SSI 31, 207-221.

Theodorakopoulos, E. (2010), Ancient Rome at the Cinema. Story and Spectacle in Hollywood and Rome. Exeter, Bristol, Phoenix Press. 
Viganò, A. (1997), «Il western: una nuova frontiera per il mito" in Il mito Classico e il Cinema. Genova, D.AR.FI.CL.ET. «F. Della Corte», 19-25.

White, H. (1988), «Historiography and Historiophoty», AHR 93, 1193-1199.

Williams, M. (2009), «The Idol Body: Stars, Statuary and the Classical Epic», Film \& History 39/2, 39-48.

Winkler, M. M. (2001a), "The Roman Empire in American Cinema after 1945" in S. R. Joshel, M. Malamud, D. T. McGuire, eds., Imperial Projections. Ancient Rome in Modern Popular Culture. Baltimore/London, The Johns Hopkins University Press, 50-76.

__ (2009), Cinema and Classical Texts. Apollo's New Light. Cambridge, University Press.

- ed. (1991), Classics and Cinema. London/Toronto, Bucknell University Press.

- ed. (2001), Classical Myth and Culture in the Cinema. Oxford, University Press.

—_ ed. (2007), Spartacus. Film and History. Oxford, Blackwell.

Wyxe, M. (1997), Projecting the Past. Ancient Rome, Cinema and History. New York/London, Routledge.

__ (2002), The Roman Mistress. Ancient and Modern 
Representations. Oxford, University Press.

—_ (2004), «Film Style and Fascism: Julius Caesan», Film Studies 4, 58-74. 


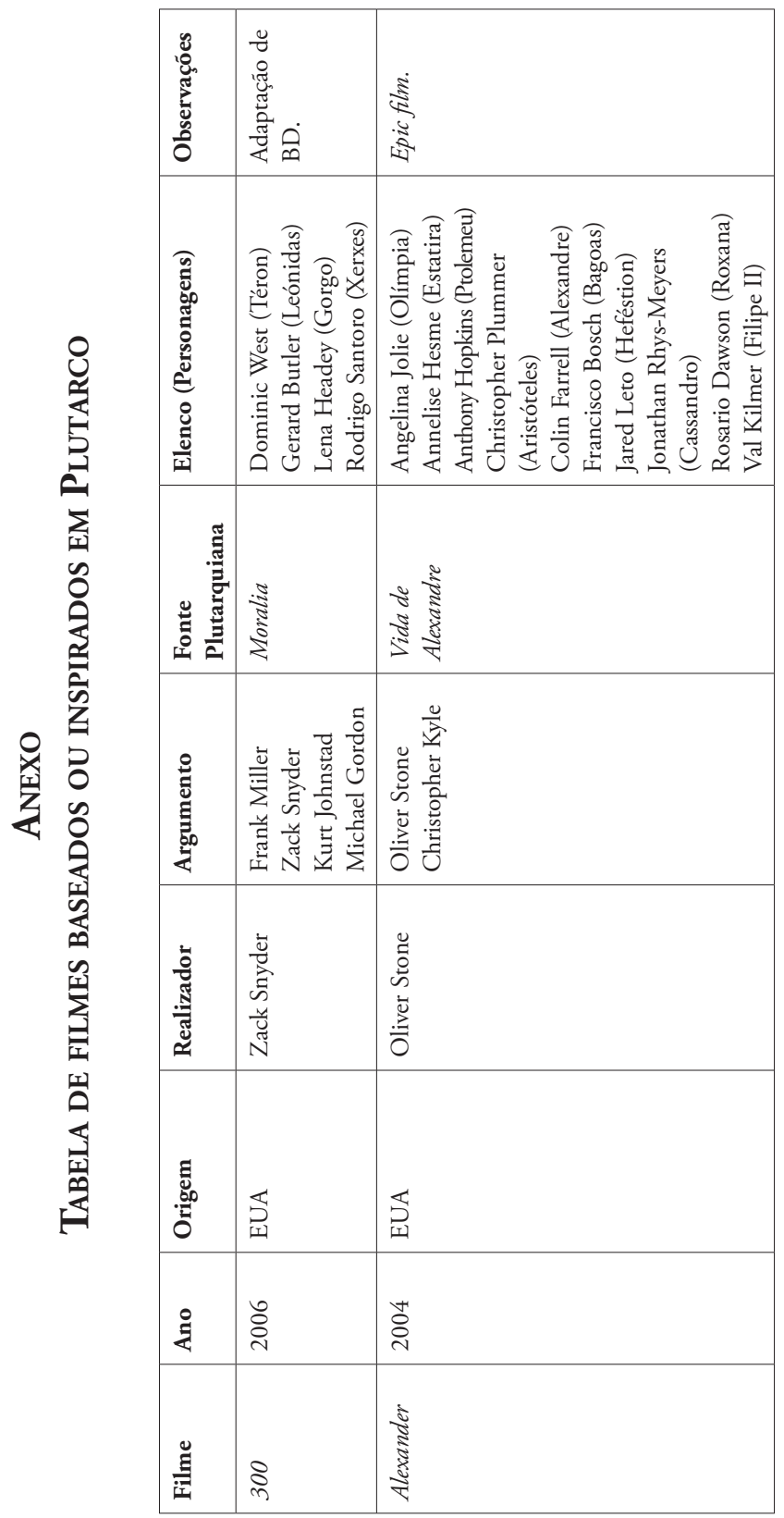

252 


\begin{tabular}{|c|c|c|}
\hline 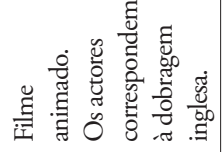 & 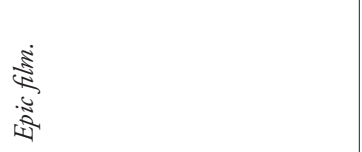 & 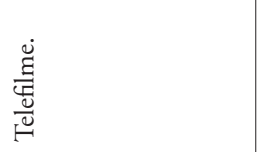 \\
\hline 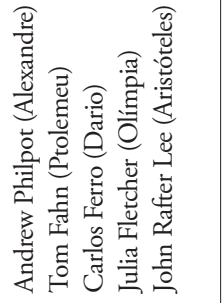 & 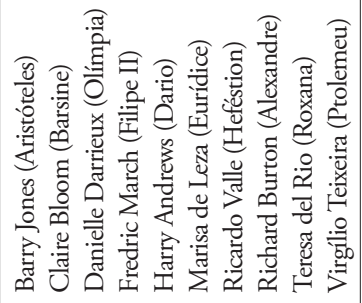 & 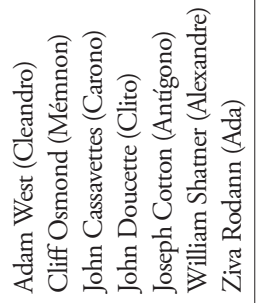 \\
\hline 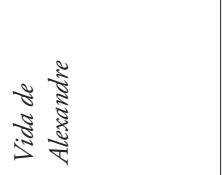 & 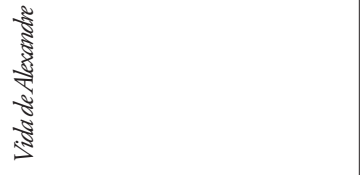 & 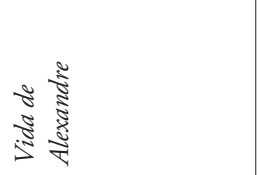 \\
\hline 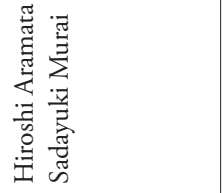 & 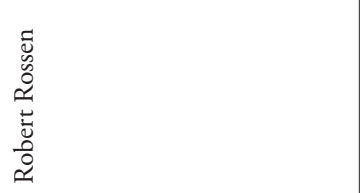 & 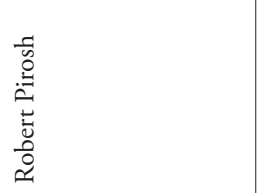 \\
\hline 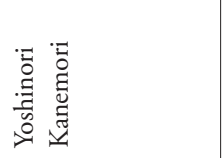 & 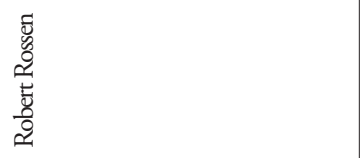 & 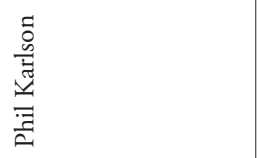 \\
\hline 疍 & 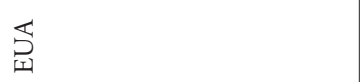 & 劲 \\
\hline$\hat{\widehat{\partial}}$ & 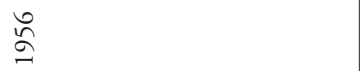 & $\begin{array}{l}\infty \\
\stackrel{\circ}{\circ}\end{array}$ \\
\hline 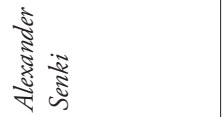 & 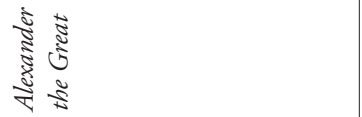 & 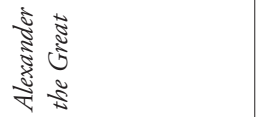 \\
\hline
\end{tabular}




\begin{tabular}{|c|c|c|c|}
\hline 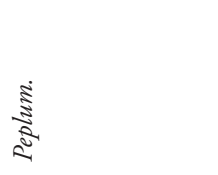 & 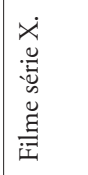 & 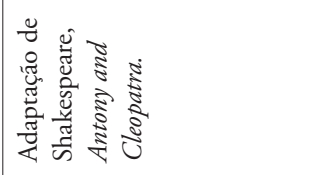 & 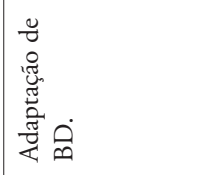 \\
\hline 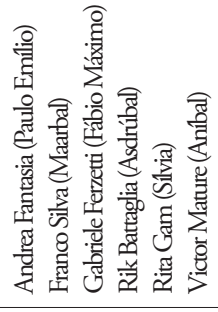 & 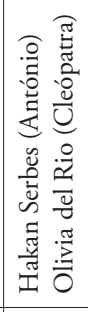 & 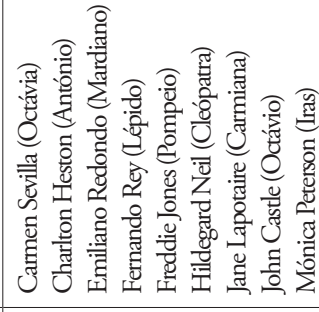 & 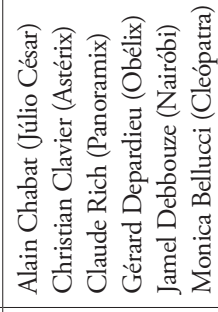 \\
\hline 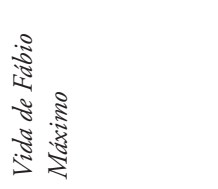 & 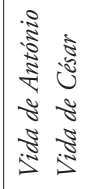 & 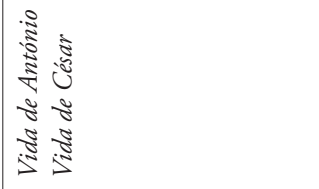 & 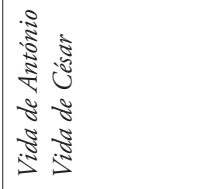 \\
\hline 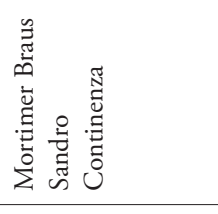 & 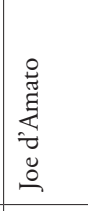 & 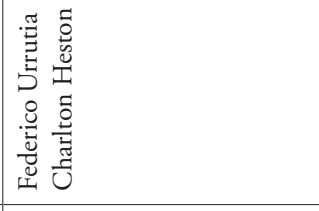 & 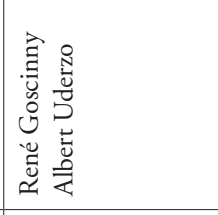 \\
\hline 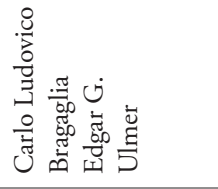 & 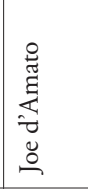 & 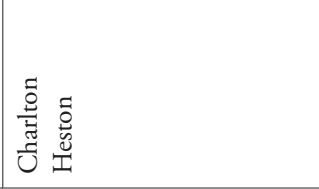 & 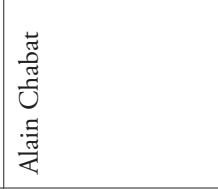 \\
\hline 窇 & 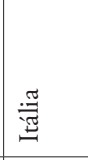 & 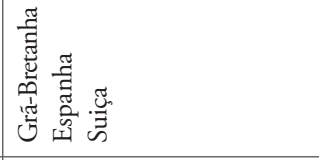 & 焉 \\
\hline$\stackrel{\approx}{\approx}$ & $\stackrel{2}{\curvearrowright}$ & $\stackrel{\Re}{\stackrel{2}{2}}$ & 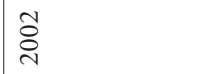 \\
\hline है & 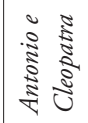 & है & 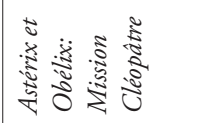 \\
\hline
\end{tabular}




\begin{tabular}{|c|c|c|c|}
\hline 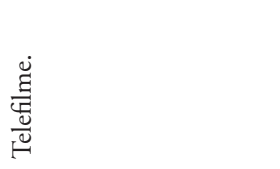 & 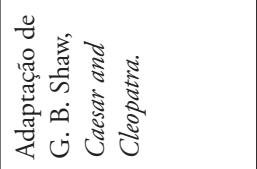 & $\frac{\dot{j}}{\sum_{i}}$ & 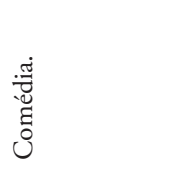 \\
\hline 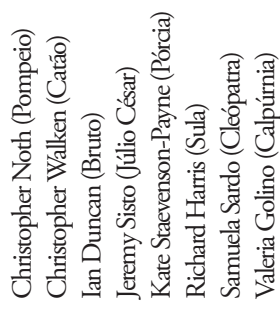 & 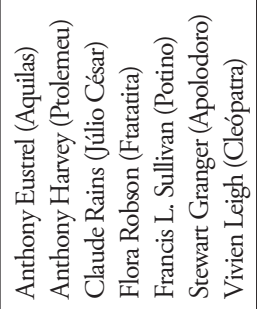 & 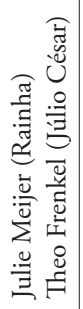 & 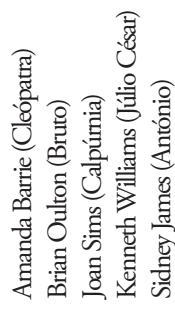 \\
\hline 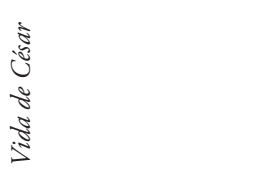 & 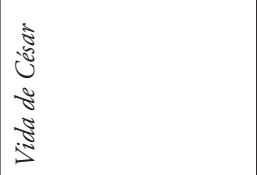 & 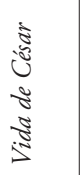 & 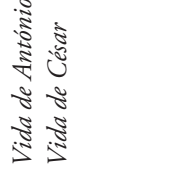 \\
\hline 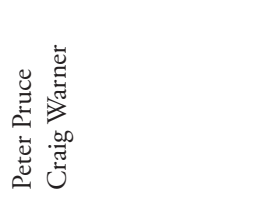 & 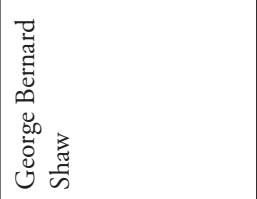 & $n$. & 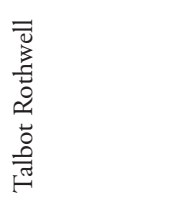 \\
\hline $\begin{array}{l}\frac{\bar{v}}{\bar{y}} \\
\dot{\bar{j}}\end{array}$ & 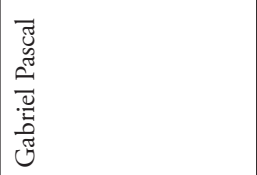 & 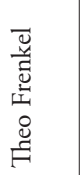 & 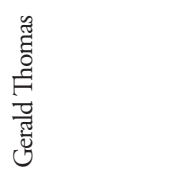 \\
\hline 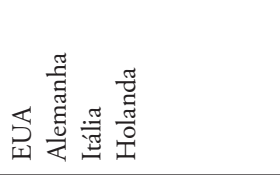 & 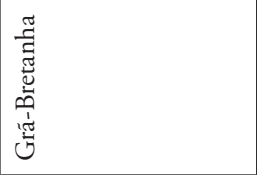 & 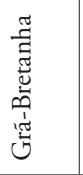 & 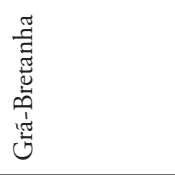 \\
\hline ڤิ & 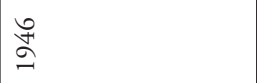 & $\vec{\Xi}$ & \begin{tabular}{l}
\multirow{2}{}{} \\
$\stackrel{2}{ }$
\end{tabular} \\
\hline נू & 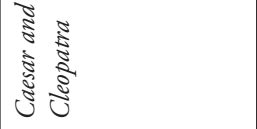 & 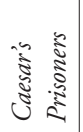 & 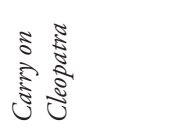 \\
\hline
\end{tabular}




\begin{tabular}{|c|c|c|}
\hline 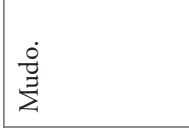 & $\sum_{i}^{8}$ & 离 \\
\hline 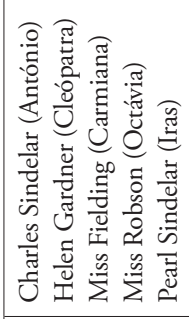 & 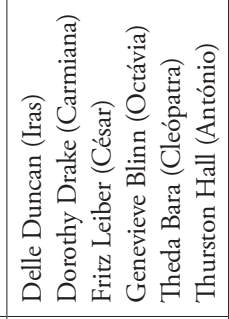 & 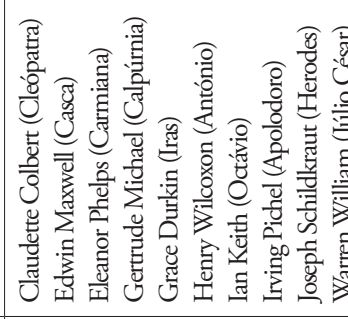 \\
\hline 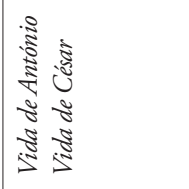 & 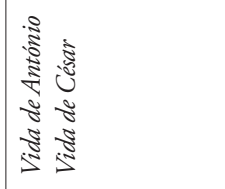 & 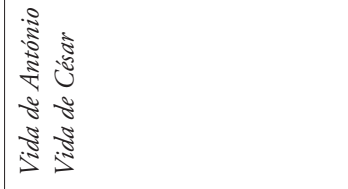 \\
\hline 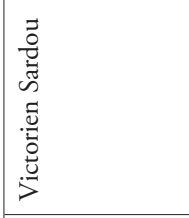 & 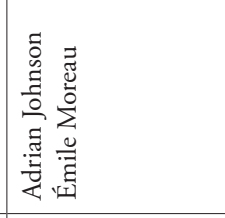 & 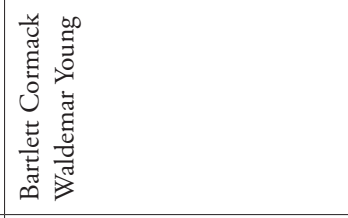 \\
\hline 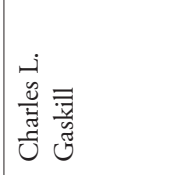 & 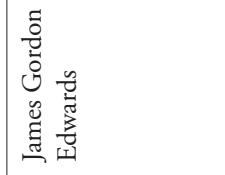 & 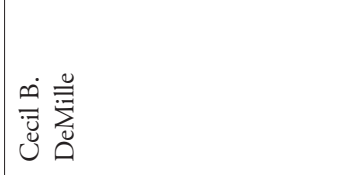 \\
\hline 公 & 壳 & 空 \\
\hline$\stackrel{\Xi}{\Xi}$ & $\widehat{\approx}$ & $\stackrel{+}{\stackrel{\sim}{\Omega}}$ \\
\hline 造 & छै & 造 \\
\hline
\end{tabular}




\begin{tabular}{|c|c|c|}
\hline 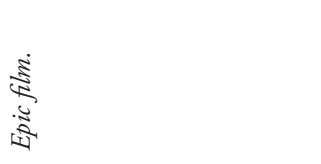 & 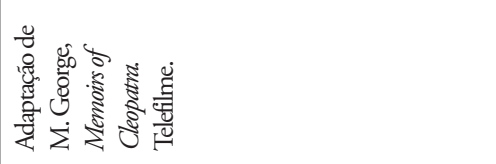 & 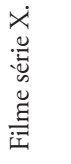 \\
\hline 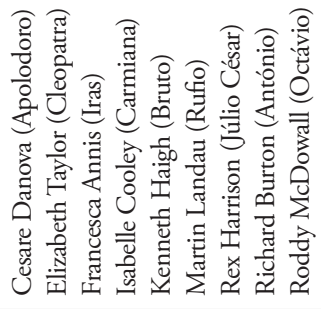 & 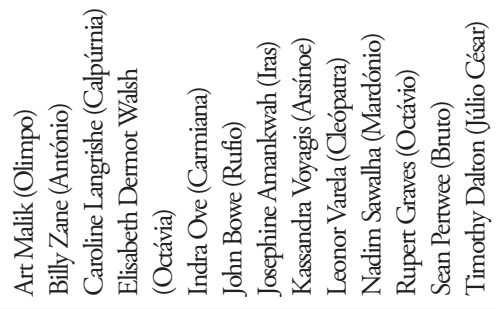 & 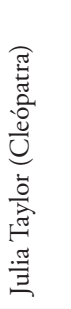 \\
\hline 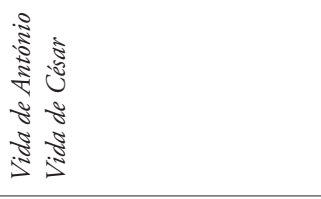 & 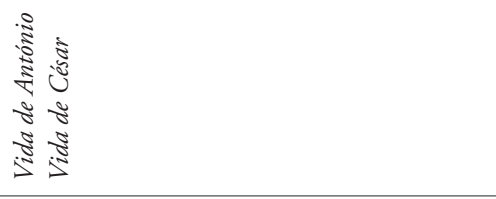 & 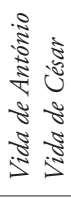 \\
\hline 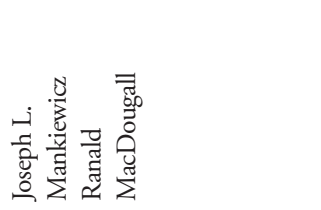 & 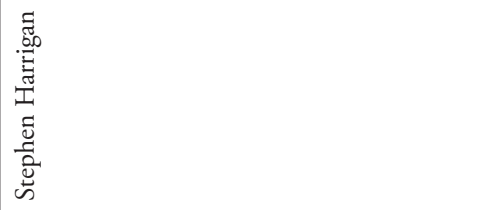 & 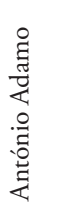 \\
\hline 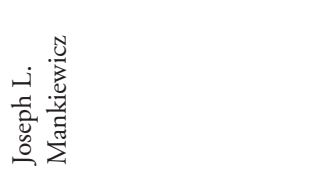 & 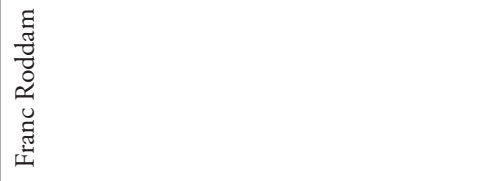 & 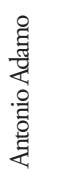 \\
\hline 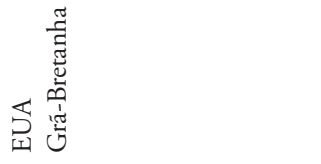 & 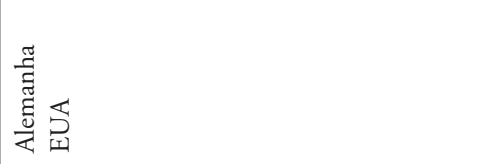 & 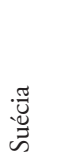 \\
\hline శ్ర & & $\stackrel{\text { }}{\stackrel{\sim}{े}}$ \\
\hline 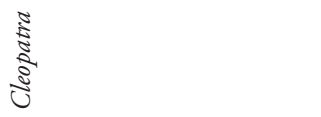 & 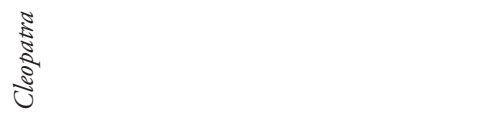 & 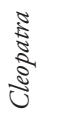 \\
\hline
\end{tabular}




\begin{tabular}{|c|c|c|c|c|c|}
\hline & 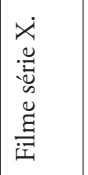 & $\begin{array}{l}\text { है } \\
\text { है } \\
\cong\end{array}$ & & $\mid$ & 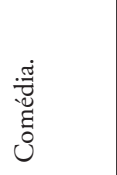 \\
\hline 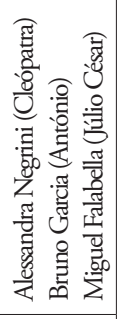 & 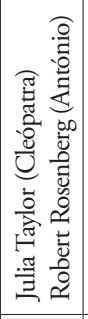 & 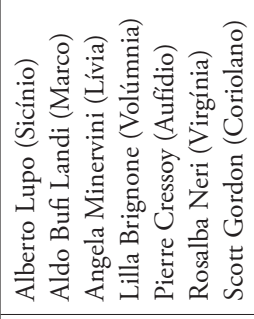 & 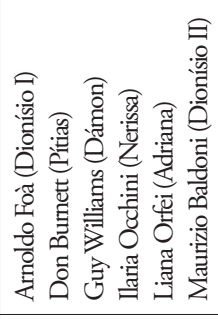 & 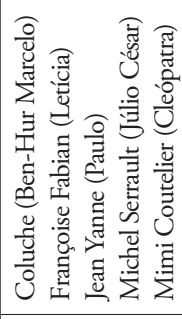 & 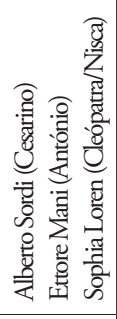 \\
\hline 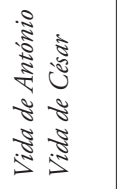 & 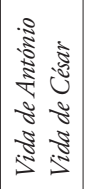 & ฐँ & 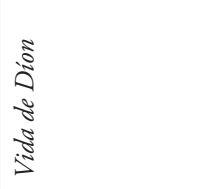 & 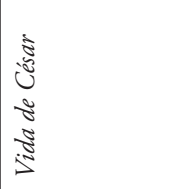 & 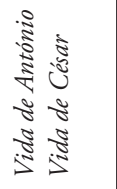 \\
\hline 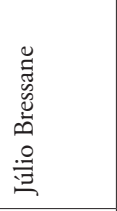 & 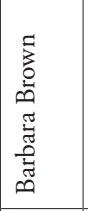 & 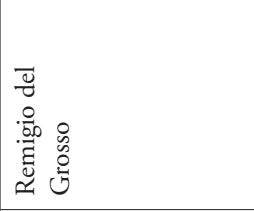 & 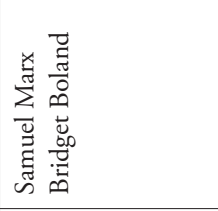 & 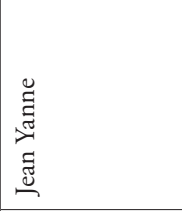 & 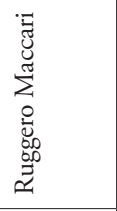 \\
\hline 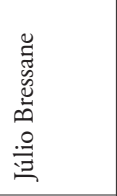 & 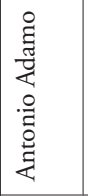 & 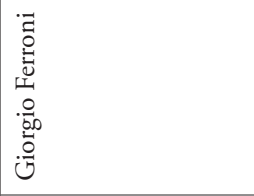 & 竞 & 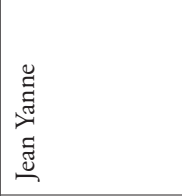 & 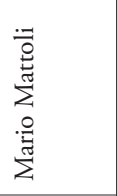 \\
\hline 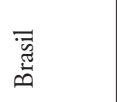 & 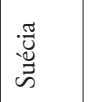 & 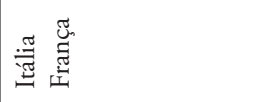 & 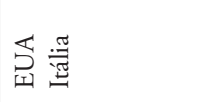 & 莺 & 䔍 \\
\hline ڤ్ & 䓂 & $\begin{array}{l}\stackrel{+}{2} \\
ٌ\end{array}$ & ऽ్ & {$\left[\begin{array}{l}\infty \\
\stackrel{2}{\sigma}\end{array}\right.$} & $\stackrel{\text { }}{\Omega}$ \\
\hline 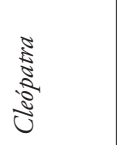 & 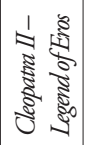 & 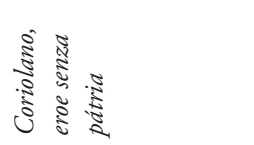 & 章 & 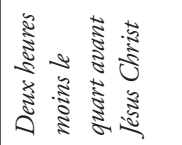 & 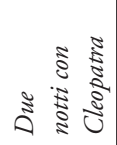 \\
\hline
\end{tabular}




\begin{tabular}{|c|c|c|c|}
\hline$\frac{5}{3}$ & 离 & $\frac{\dot{g}}{\frac{B}{z}}$ & $\frac{\text { है }}{2}$ \\
\hline 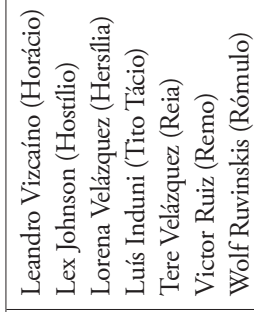 & 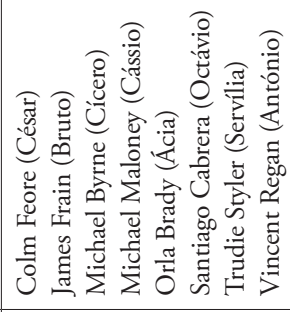 & 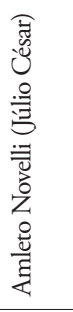 & 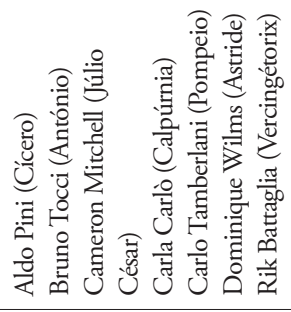 \\
\hline 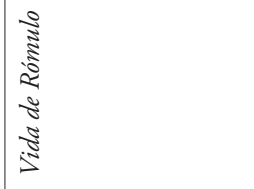 & 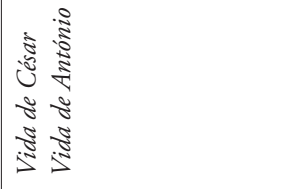 & 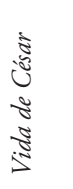 & 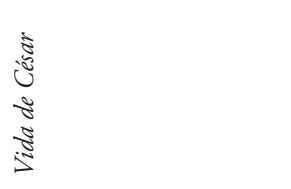 \\
\hline 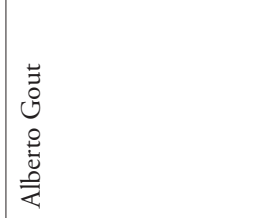 & 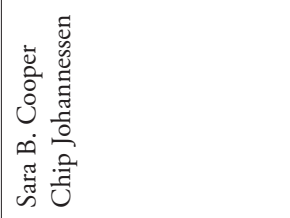 & 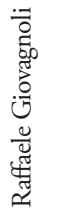 & 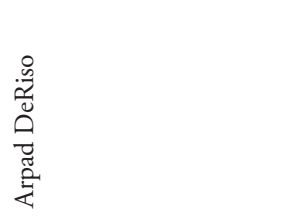 \\
\hline 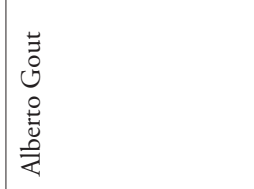 & 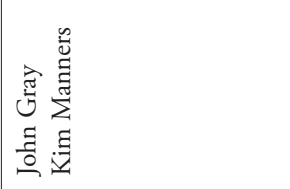 & 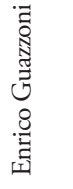 & 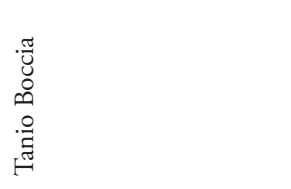 \\
\hline 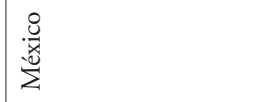 & 恿 & 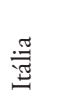 & 䔍 \\
\hline$\stackrel{\circ}{\precsim}$ & 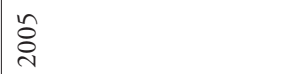 & $\underset{\Xi}{\stackrel{\Xi}{2}}$ & 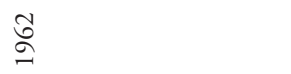 \\
\hline 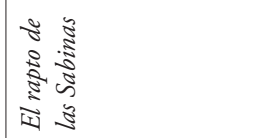 & 离 & है & 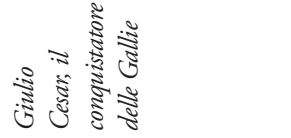 \\
\hline
\end{tabular}




\begin{tabular}{|c|c|c|c|c|}
\hline$\frac{8}{g^{\prime}}$ & 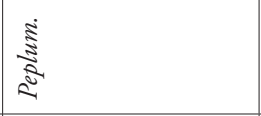 & 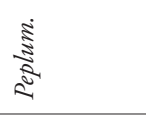 & 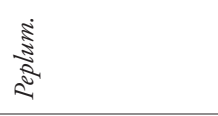 & 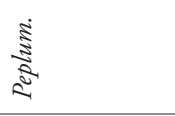 \\
\hline 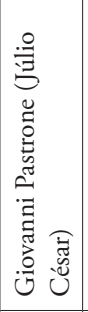 & 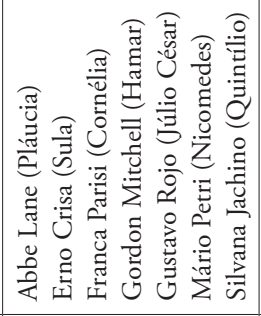 & 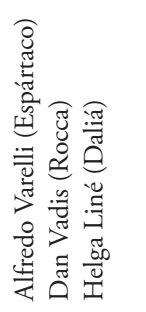 & 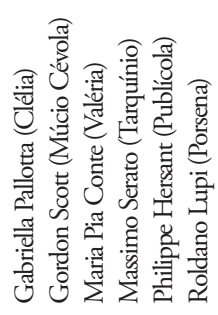 & 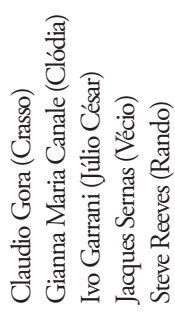 \\
\hline 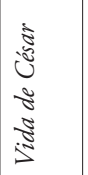 & 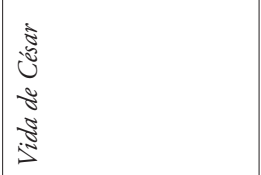 & 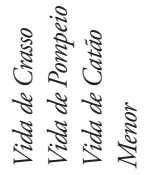 & 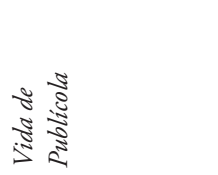 & 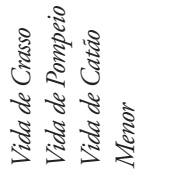 \\
\hline$n$. & 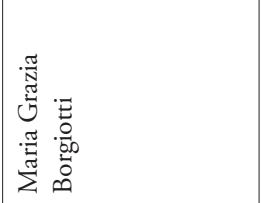 & 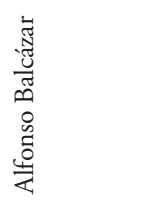 & 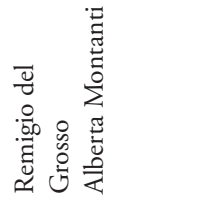 & 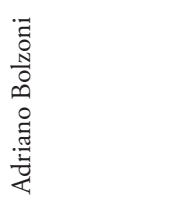 \\
\hline 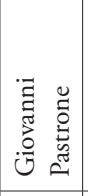 & 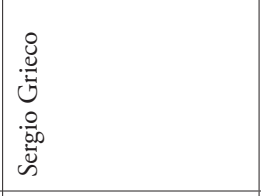 & 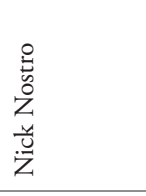 & 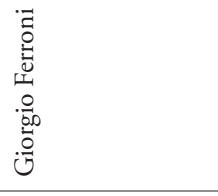 & 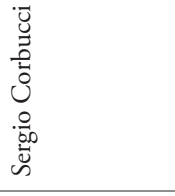 \\
\hline 窇 & 螞 & 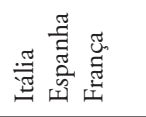 & 专 & 急 \\
\hline ఏ & $\underset{\Xi}{\sigma}$ & 苋 & 苋 & $\stackrel{\mathscr{J}}{\sigma}$ \\
\hline 胥 & 竞 & 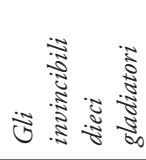 & 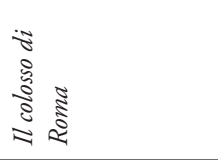 & 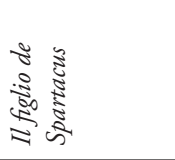 \\
\hline
\end{tabular}




\begin{tabular}{|c|c|}
\hline 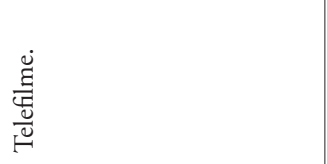 & 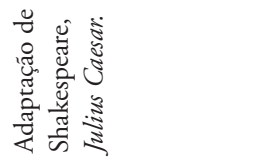 \\
\hline 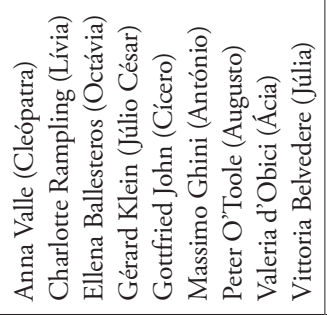 & 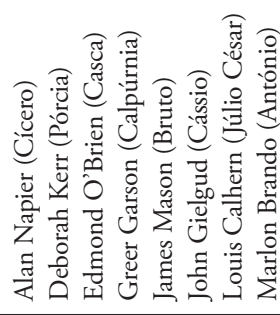 \\
\hline 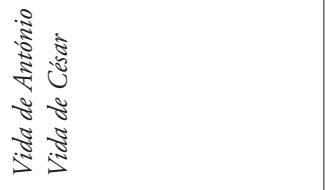 & 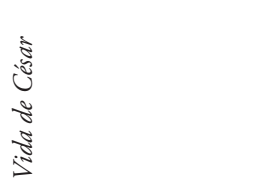 \\
\hline 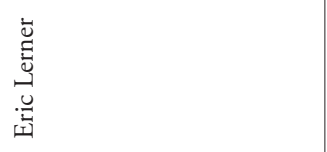 & 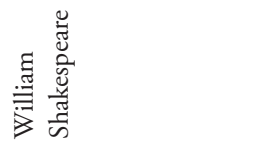 \\
\hline 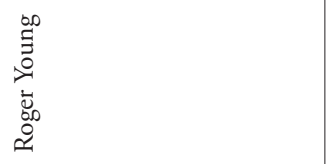 & 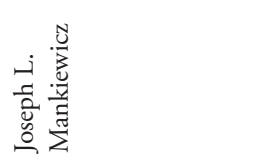 \\
\hline 贫 & 贫 \\
\hline 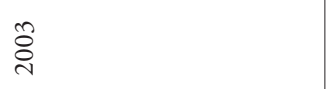 & $\stackrel{\Re}{\approx}$ \\
\hline 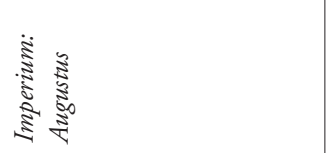 & 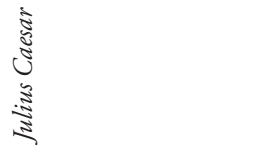 \\
\hline
\end{tabular}




\begin{tabular}{|c|c|c|}
\hline 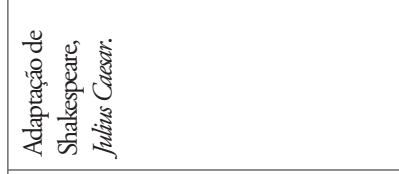 & 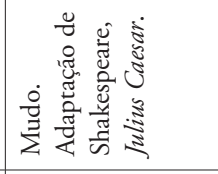 & 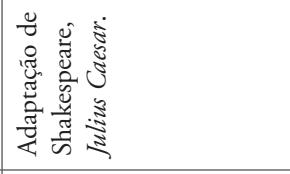 \\
\hline 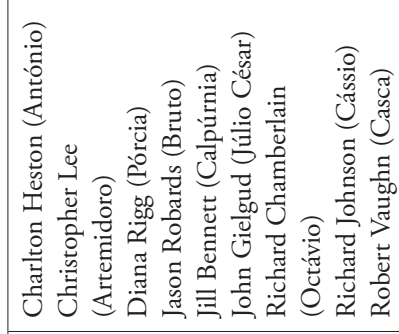 & 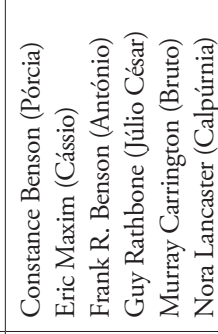 & 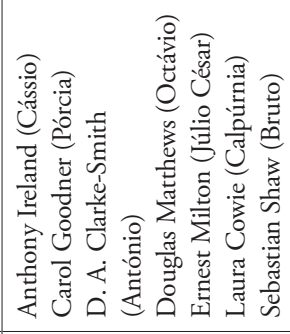 \\
\hline 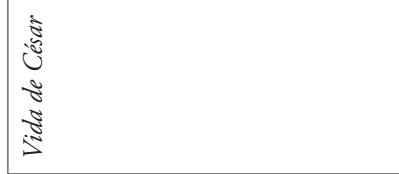 & 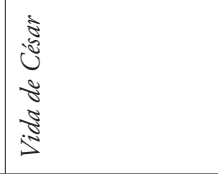 & 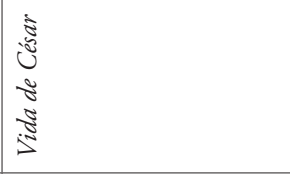 \\
\hline 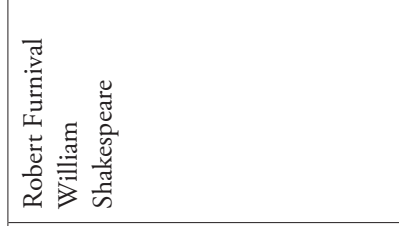 & 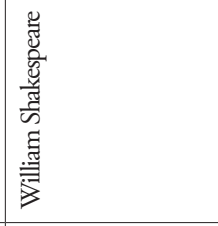 & 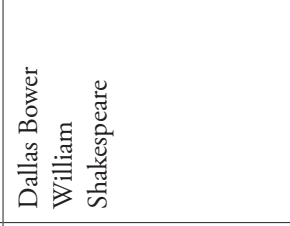 \\
\hline 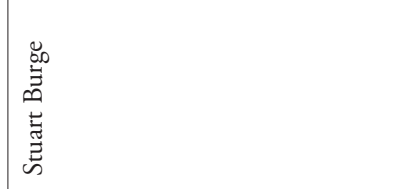 & 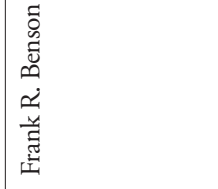 & 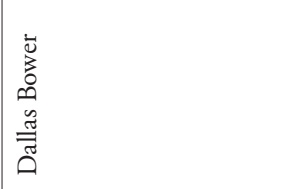 \\
\hline 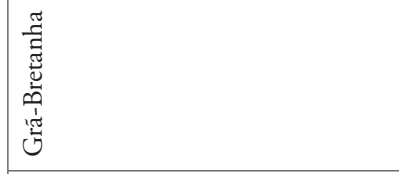 & 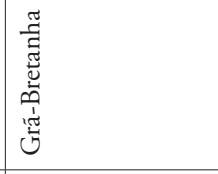 & 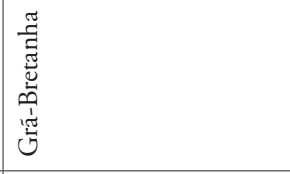 \\
\hline$\stackrel{2}{2}$ & $\bar{\Xi}$ & $\stackrel{\infty}{\stackrel{\infty}{2}}$ \\
\hline 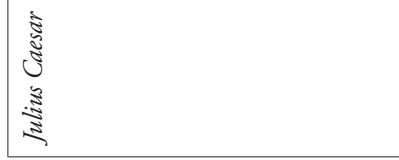 & 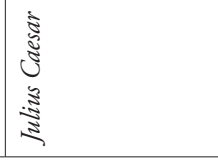 & 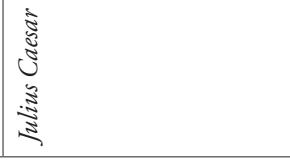 \\
\hline
\end{tabular}




\begin{tabular}{|c|c|c|c|}
\hline 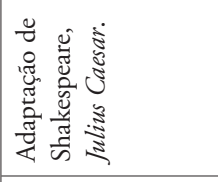 & 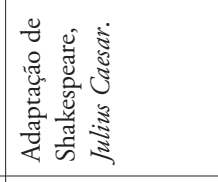 & 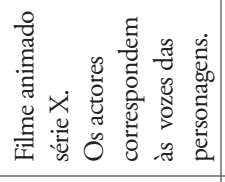 & $\frac{5}{5}$ \\
\hline 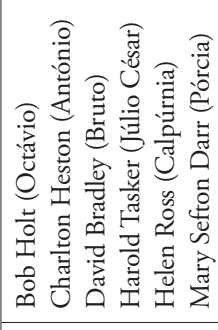 & 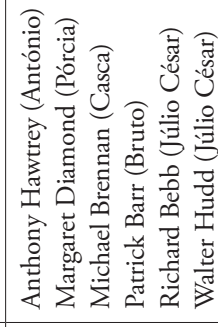 & 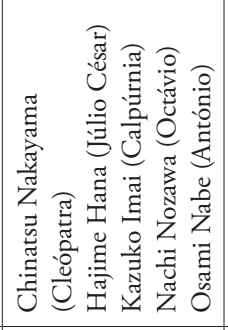 & 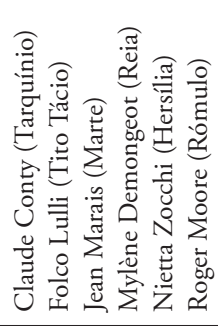 \\
\hline 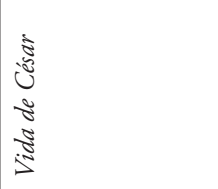 & 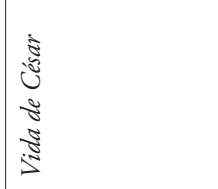 & 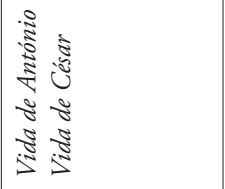 & 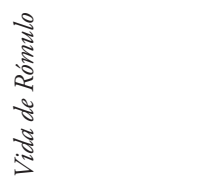 \\
\hline 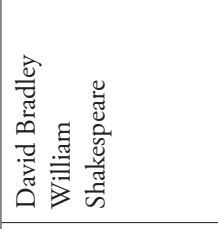 & 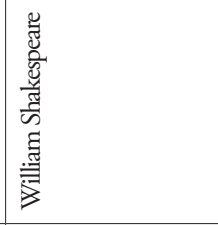 & 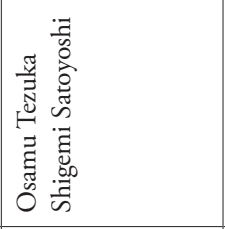 & 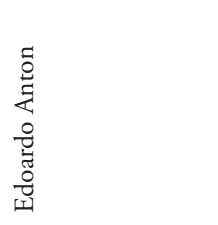 \\
\hline 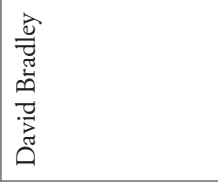 & 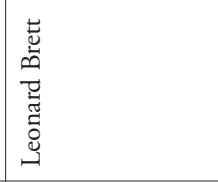 & 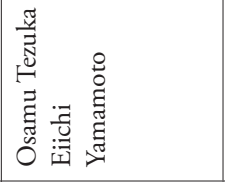 & 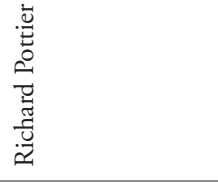 \\
\hline 恿 & 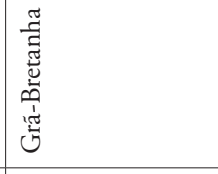 & 总 & 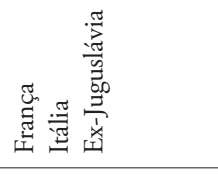 \\
\hline$\stackrel{\text { }}{\check{2}}$ & $\overrightarrow{\check{\Omega}}$ & $\stackrel{尺}{2}$ & $\begin{array}{l}\overrightarrow{0} \\
2\end{array}$ \\
\hline 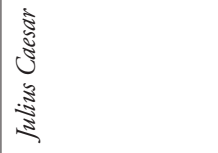 & 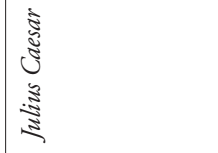 & 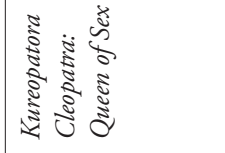 & 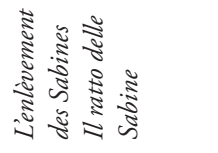 \\
\hline
\end{tabular}




\begin{tabular}{|c|c|c|c|c|}
\hline 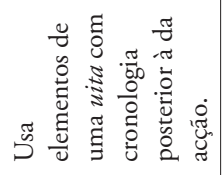 & $\frac{\Omega^{2}}{\frac{5}{5}}$ & 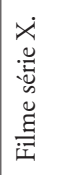 & $\sum_{\dot{n}}^{\dot{g}}$ & \\
\hline 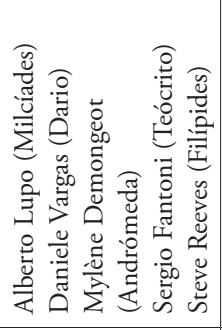 & 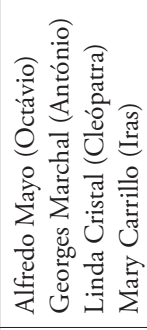 & 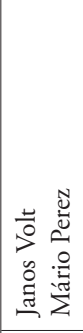 & 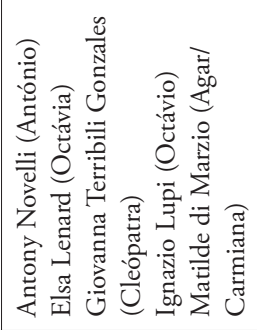 & 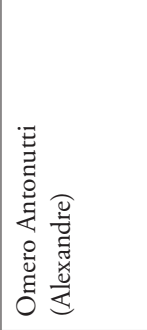 \\
\hline 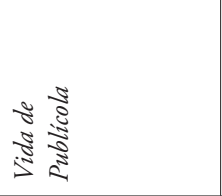 & 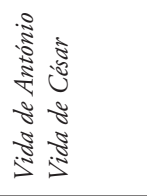 & 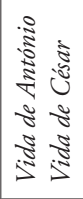 & 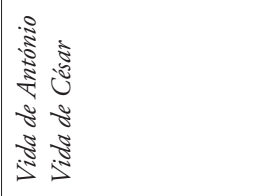 & 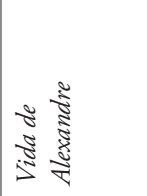 \\
\hline 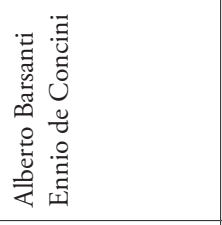 & 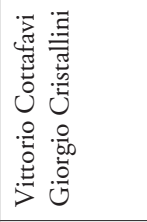 & n. & 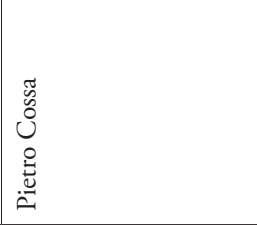 & 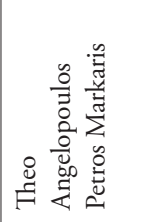 \\
\hline 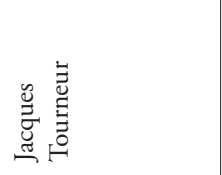 & 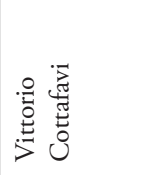 & 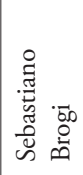 & 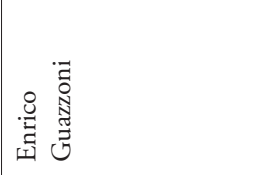 & 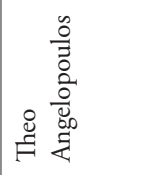 \\
\hline 茎莺 & 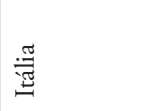 & 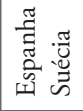 & 穿 & 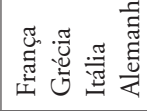 \\
\hline$\stackrel{\approx}{\approx}$ & $\stackrel{\approx}{\approx}$ & ڤ̊̀े & $\stackrel{m}{\stackrel{2}{2}}$ & $\begin{array}{l}\stackrel{\circ}{\stackrel{2}{2}} \\
\end{array}$ \\
\hline 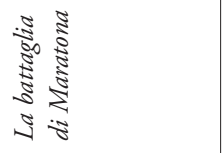 & 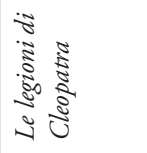 & $\begin{array}{l}\text { हे } \\
\text { हूँ } \\
\text { है }\end{array}$ & 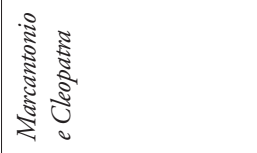 & 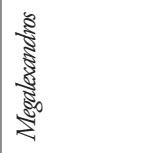 \\
\hline
\end{tabular}




\begin{tabular}{|c|c|c|c|}
\hline 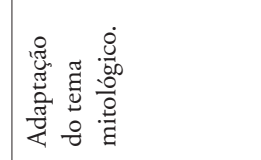 & 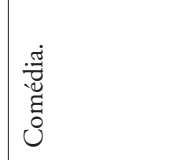 & 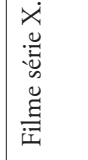 & 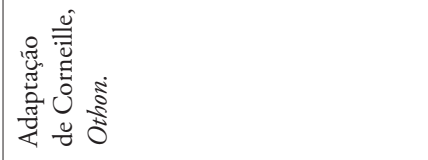 \\
\hline 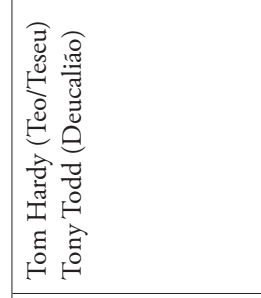 & 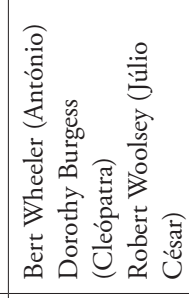 & n. & 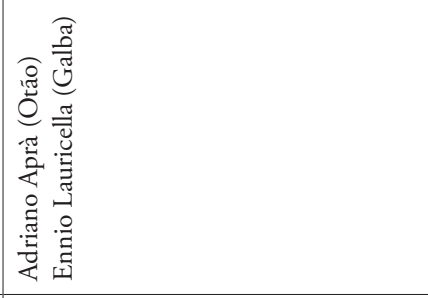 \\
\hline 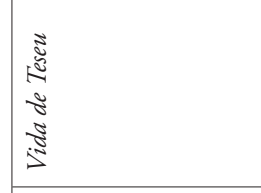 & 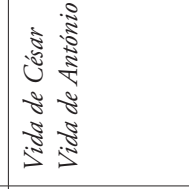 & 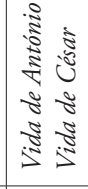 & $\begin{array}{l}8 \\
8 \\
z \\
z \\
5 \\
5\end{array}$ \\
\hline 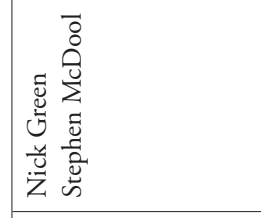 & 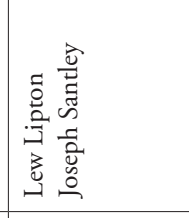 & n. & 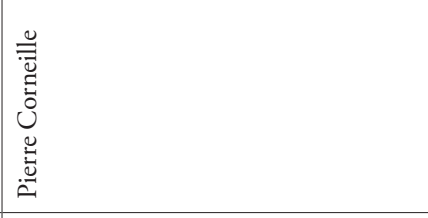 \\
\hline 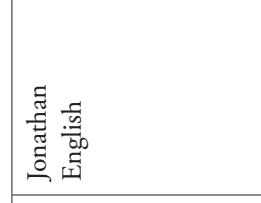 & 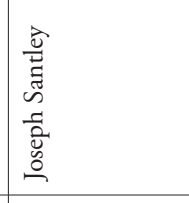 & 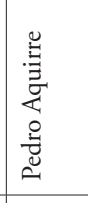 & 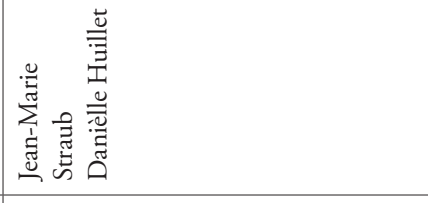 \\
\hline 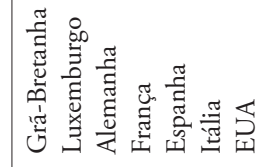 & 岂 & 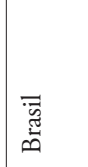 & 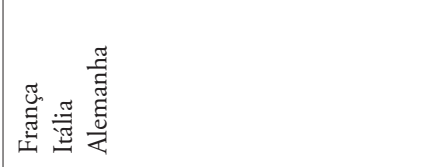 \\
\hline ڤ્స & $\overrightarrow{\widetilde{\Omega}}$ & 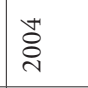 & ڤे \\
\hline है & 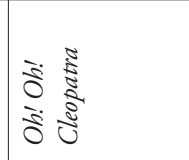 & 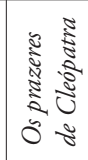 & 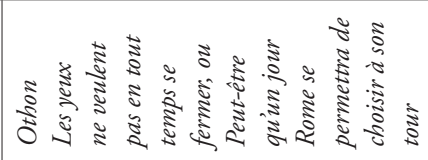 \\
\hline
\end{tabular}




\begin{tabular}{|c|c|}
\hline & 离 \\
\hline 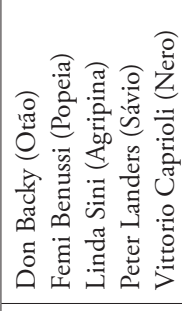 & 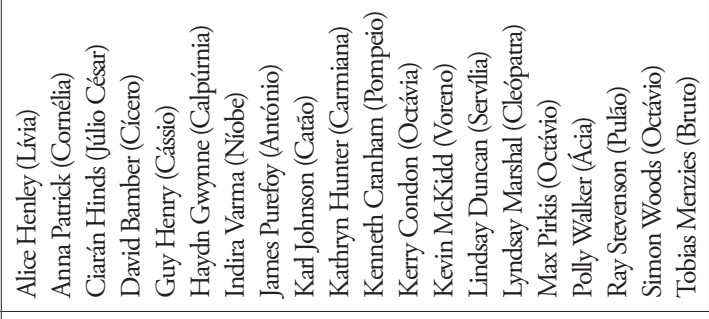 \\
\hline \begin{tabular}{|l}
3 \\
0 \\
8 \\
3 \\
3 \\
$z$
\end{tabular} & 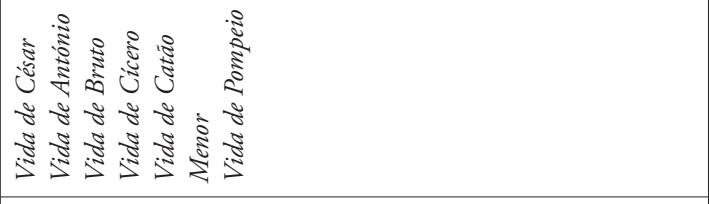 \\
\hline 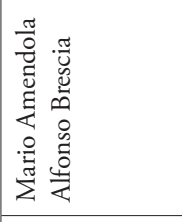 & 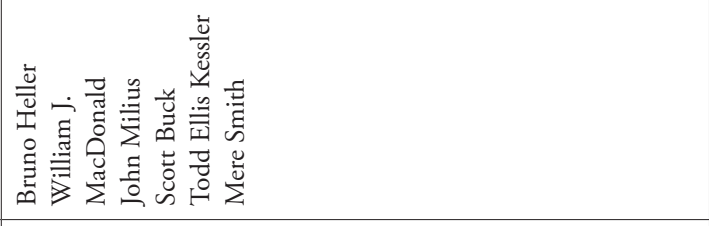 \\
\hline 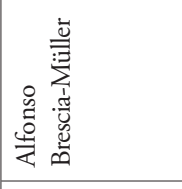 & 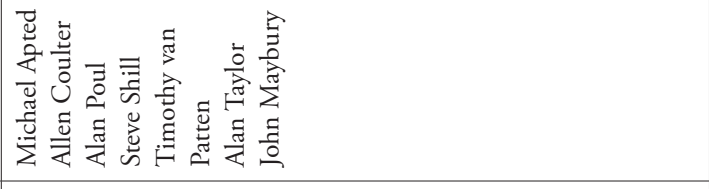 \\
\hline 茎 & 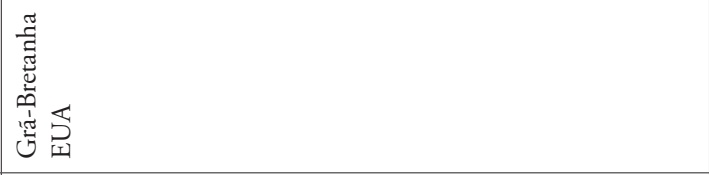 \\
\hline$\stackrel{N}{\stackrel{N}{2}}$ & 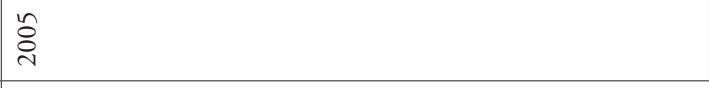 \\
\hline 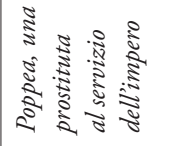 & 气ั \\
\hline
\end{tabular}




\begin{tabular}{|c|c|c|}
\hline$\frac{5}{\sqrt{2}}$ & 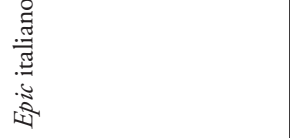 & 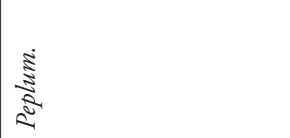 \\
\hline 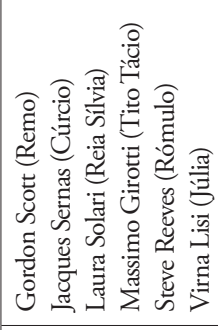 & 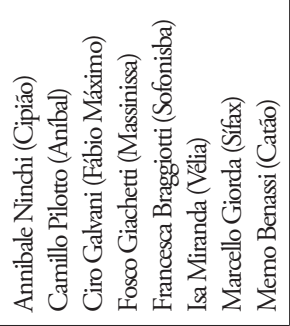 & 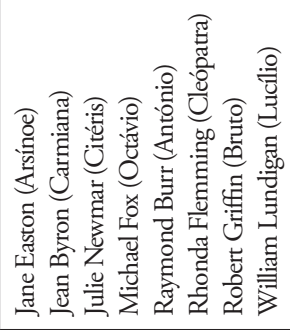 \\
\hline 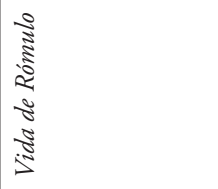 & 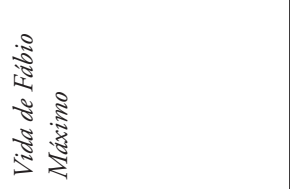 & 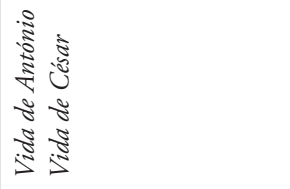 \\
\hline 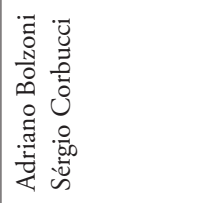 & 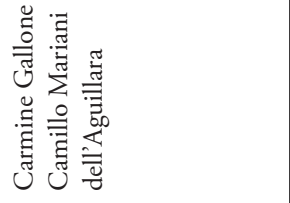 & 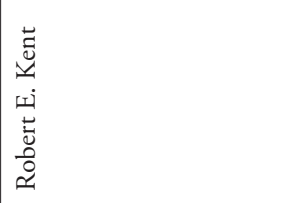 \\
\hline 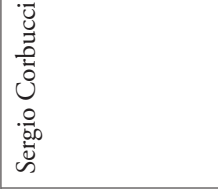 & 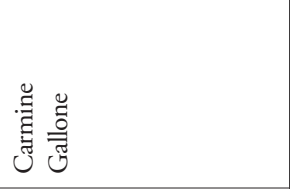 & 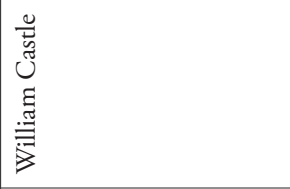 \\
\hline 愛 & 泶 & 壳 \\
\hline$\precsim$ & $\stackrel{\curvearrowright}{\sigma}$ & $\tilde{\Omega}$ \\
\hline 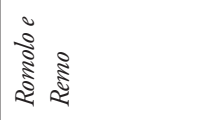 & 言 & 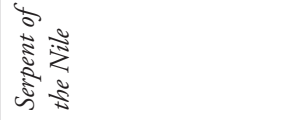 \\
\hline
\end{tabular}




\begin{tabular}{|c|c|c|c|c|}
\hline 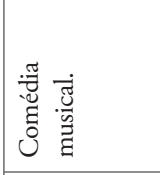 & & 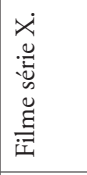 & 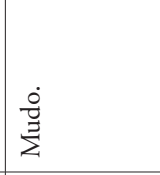 & \\
\hline 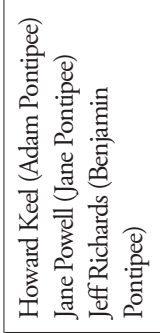 & 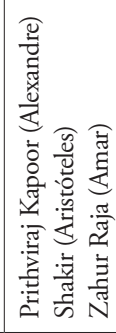 & 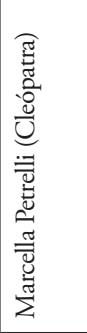 & 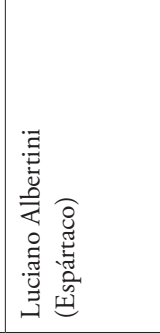 & 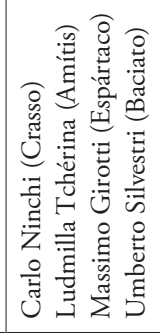 \\
\hline 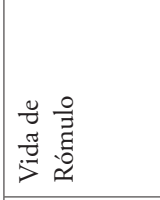 & 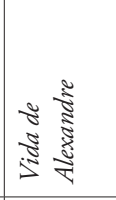 & 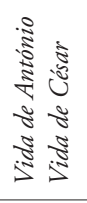 & 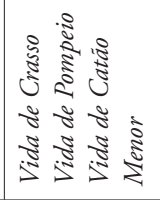 & 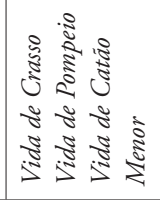 \\
\hline 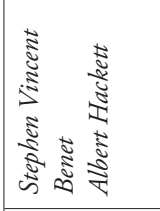 & 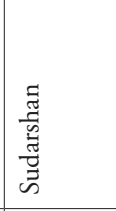 & 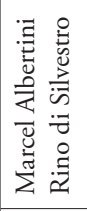 & 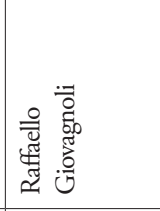 & 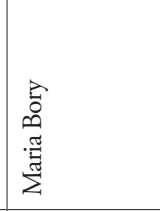 \\
\hline 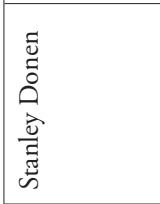 & 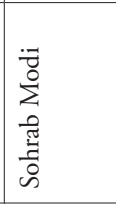 & 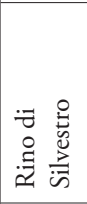 & 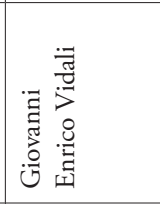 & 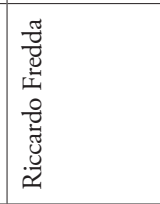 \\
\hline 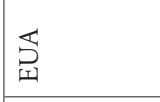 & $\stackrel{\widetilde{g}}{\Xi}$ & 眔营 & 愛 & 恚䔍 \\
\hline 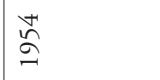 & $\underset{I}{\stackrel{F}{2}}$ & $\begin{array}{l}\mathscr{心} \\
\stackrel{2}{\beth}\end{array}$ & $\stackrel{2}{2}$ & $\tilde{\check{\Omega}}$ \\
\hline 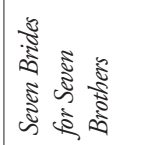 & 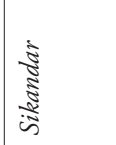 & 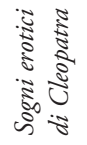 & $\begin{array}{l}\text { हूँ } \\
\text { है } \\
\text { के }\end{array}$ & $\begin{array}{l}\text { हूँ } \\
\text { है } \\
\text { के }\end{array}$ \\
\hline
\end{tabular}




\begin{tabular}{|c|c|c|}
\hline 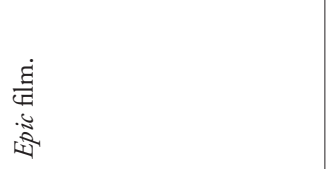 & 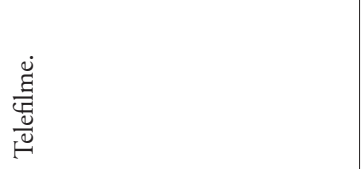 & 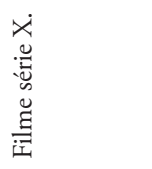 \\
\hline 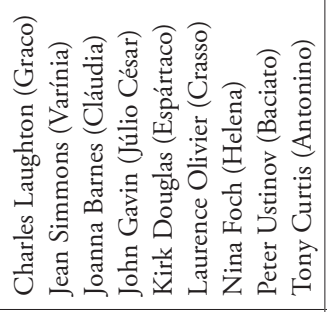 & 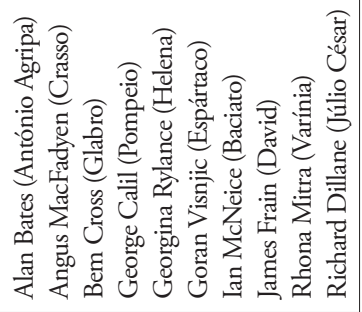 & 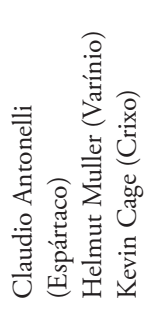 \\
\hline 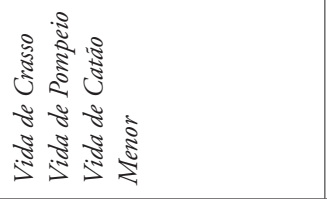 & 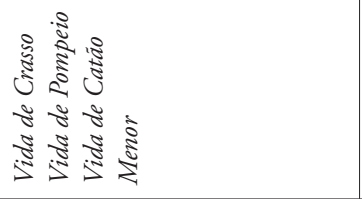 & 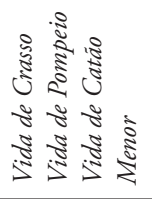 \\
\hline 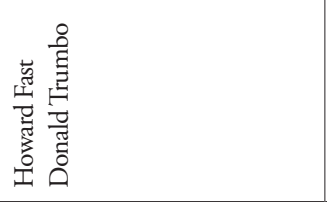 & 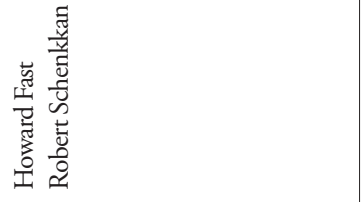 & 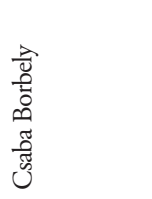 \\
\hline 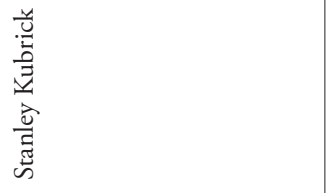 & 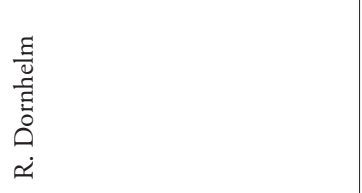 & 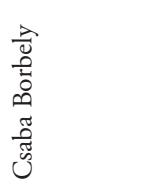 \\
\hline 古 & 贫 & 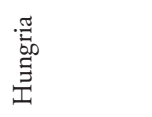 \\
\hline 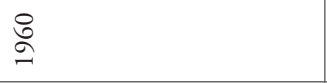 & 浐 & ঃั \\
\hline $\begin{array}{l}\text { हू } \\
\text { s. } \\
\text { की } \\
\text { की }\end{array}$ & $\begin{array}{l}\text { हू } \\
\text { है } \\
\text { की } \\
\text { की }\end{array}$ & $\begin{array}{c}\frac{3}{2} \\
\frac{3}{2} \\
\text { की }\end{array}$ \\
\hline
\end{tabular}




\begin{tabular}{|c|c|c|}
\hline : & 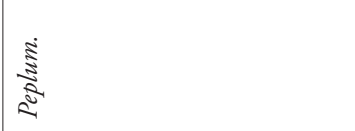 & 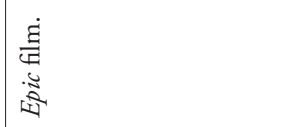 \\
\hline 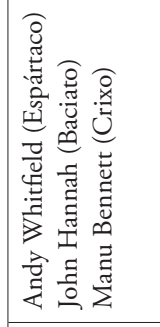 & 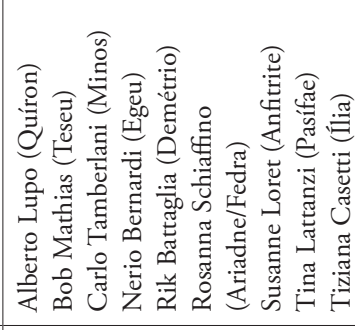 & 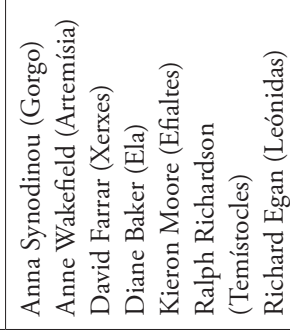 \\
\hline 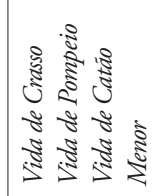 & 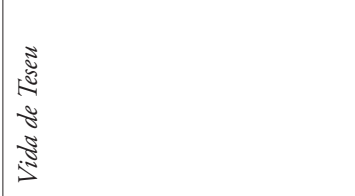 & 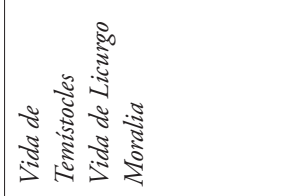 \\
\hline 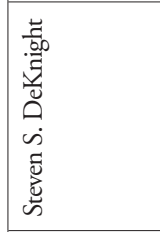 & 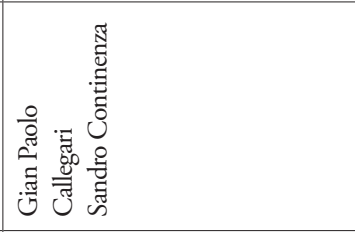 & 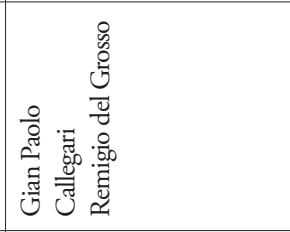 \\
\hline 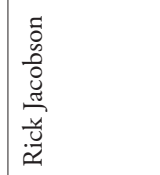 & 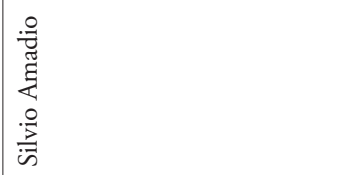 & 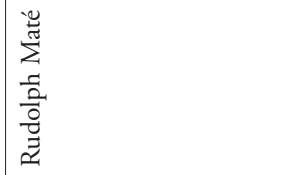 \\
\hline 聲 & 急 & 恿 \\
\hline 용 & 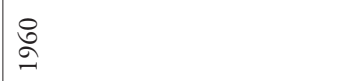 & స్ \\
\hline 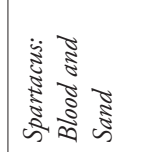 & 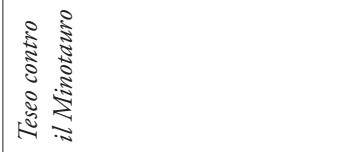 & 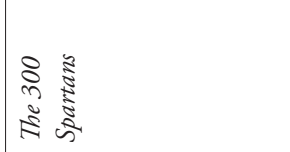 \\
\hline
\end{tabular}




\begin{tabular}{|c|c|c|}
\hline 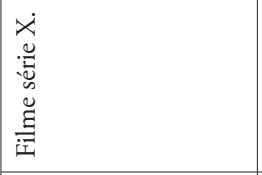 & 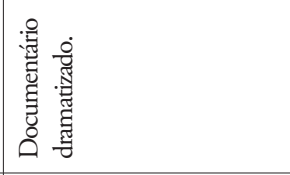 & 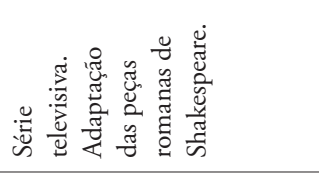 \\
\hline 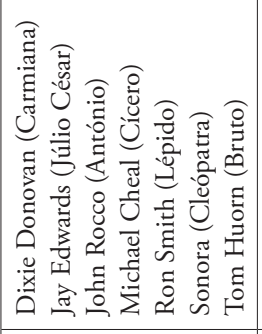 & 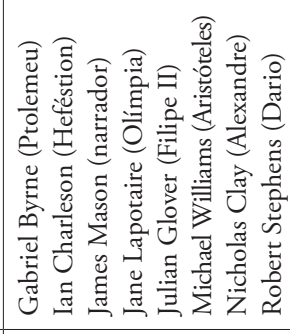 & 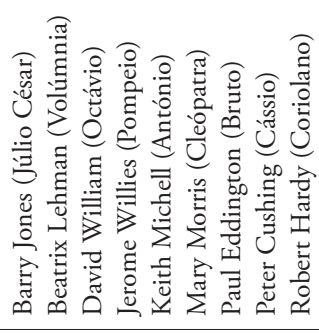 \\
\hline 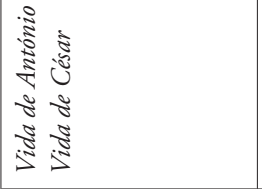 & है & 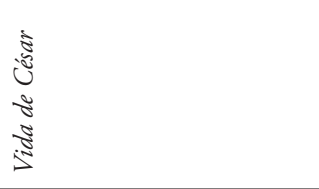 \\
\hline 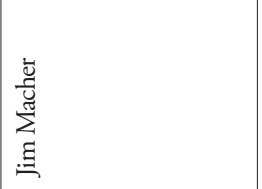 & 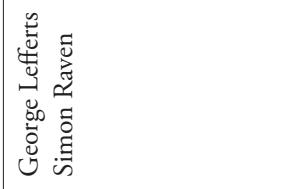 & 苞 \\
\hline 咅 & 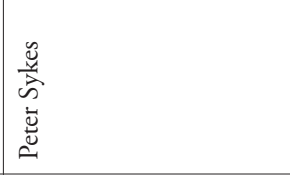 & 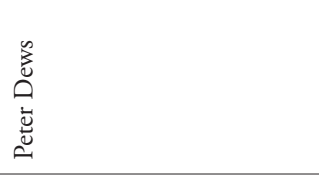 \\
\hline 㤐 & 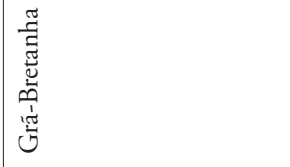 & 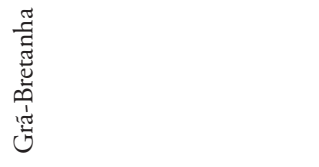 \\
\hline$\stackrel{2}{2}$ & $\vec{\infty}$ & $\stackrel{\overparen{\varrho}}{\cong}$ \\
\hline 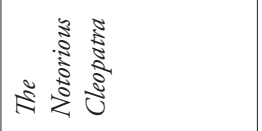 & 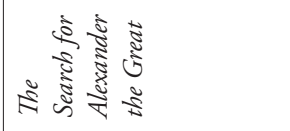 & 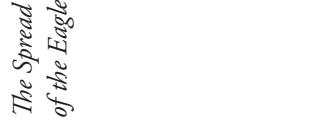 \\
\hline
\end{tabular}




\begin{tabular}{|c|c|c|}
\hline 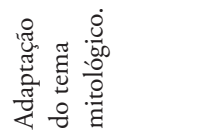 & $\frac{\sqrt{5}}{\sqrt[5]{5}}$ & 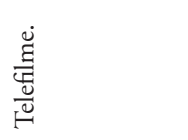 \\
\hline 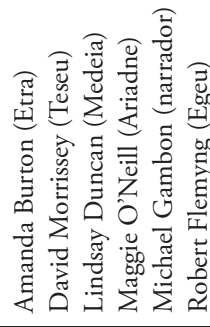 & 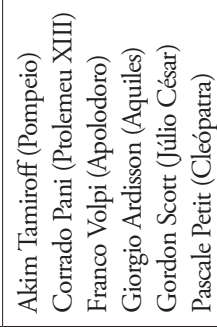 & 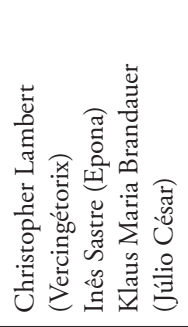 \\
\hline 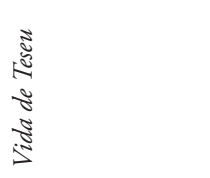 & 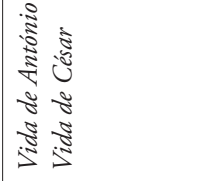 & 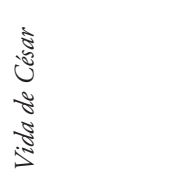 \\
\hline 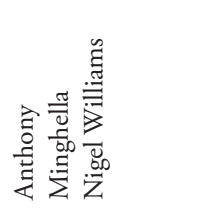 & 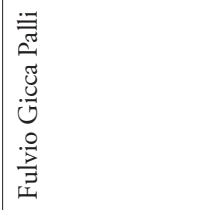 & 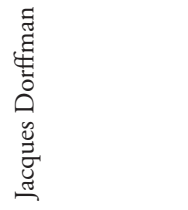 \\
\hline 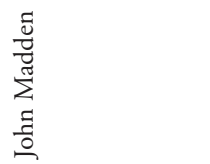 & 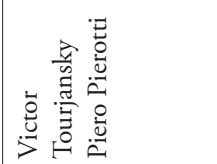 & 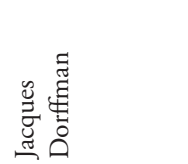 \\
\hline 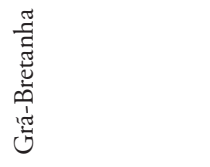 & 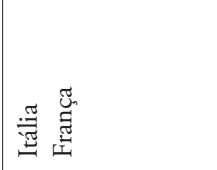 & 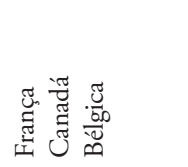 \\
\hline $\bar{\sigma}$ & ర్ర & ¿े \\
\hline 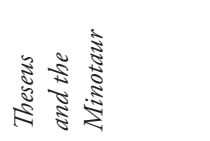 & 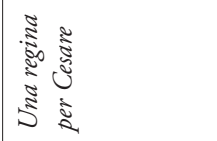 & 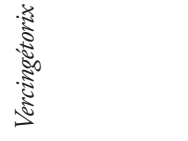 \\
\hline
\end{tabular}




\section{ÍNDICE DE FONTES ANTIGAS}

\section{Apolodoro}

Biblioteca 3.5.3: 22

\section{Aristófanes}

Cavaleiros 560: 20; 1279: 26

Râs 1317: 28

schol. ad $A v$. 1403: 25

Aristóteles

Constituição dos Atenienses 57.3: 20-21

Poética 1448a1-5: 78

\section{Ateneu}

Deipnosophistae 11.466c-d: 31; 13.606c-f: 34

\section{Aulo Gélio}

Noites áticas 6.8: 34; 16.19: 27, 16.19.1: 31

\section{Antologia Grega}

Antologia de Planudes 276: 27

Antologia Palatina 9.308: 27, 39

\section{Cícero}

Tusculanas 21.61-62: 144

\section{Cláudio Eliano}

Natureza dos animais 2.6: 34; 6.15: 34; 8.3: 34; 8.11: 34; 12.45: 27, 28, 64

\section{Dicearco}

Sobre os concursos dionisíacos: 25

Diodoro Sículo: 160

Biblioteca Histórica 18.39.2-4: 155; 19.11.1-8: 155

Diógenes Laércio

Vidas e doutrinas dos filósofos ilustres 1.94-100: 25

\section{Estesícoro}

Fr. $225 P M G: 35$

\section{Estrabáo}

Geografia 13.2.4: 31 


\section{Eurípides}

Electra 435: 28

\section{Eusébio}

Crónica: 25

\section{Flávio Josefo}

Antiguidades Judaicas 15.25-30: 208; 15.89-90: 210

Fragmenta lyrica adespota

Fr. 939 PMG: 28

\section{Helânico}

Lista das vitórias nas Carneias: 25

Heródoto: 9, 17, 24-27, 29-32, 34, 41, 48, 58, 147-149

Histórias: 30,32

1.23: 25; 1.23-24: 17, 24, 58-59; 1.24: 26; 1.24.4-5: 26; 1.24.7:26, 29;

1.24.8: 25, 27, 7. 147; 7.226: 149; 7.99: 147; 8.67-70, 87-89, 101-103: 147

\section{Higino}

De Astronomia 2.17: 22, 27

Fabulae 134: 22; 194: 27

\section{Hinos Homéricos}

Hino Homérico a Apolo: 20

3.388-439, 495: 20

Hino Homérico a Diónisos: 21

7.17-24: $21 ; 7.38-42: 22 ; 7.53: 21$

\section{Juvenal}

6.118: 211

Livro de Jonas 1.2: 23

\section{Luciano}

Diálogos dos deuses marinhos 5: 22, 27

\section{Odisseia}

10.135-574: 205

Ovídio: 42

Fastos 2.79-118: 27, 41; 2.81: 20; 2.115-116: 31; 2.117-118: 41-42

Metamorfoses 3.581-691: 22 


\section{Pausânias}

Descrição da Grécia 3.25.7: 27; 9.30.2: 27; 10.24.1: 25

\section{Píndaro}

Fr. 140b.15-17 Maehler: 28

Fr. 236 Maehler: 21

schol. ad Ol. 13.25: 25

\section{Platáo}

Protágoras 343a: 25

\section{Plínio, o Antigo}

Naturalis Historia 9.20-33: 34

\section{Plínio, o Jovem}

Epistula 9.33: 34

\section{Plutarco: passim}

Vidas Paralelas: 7, 10-13, 32, 66-68, 71, 72, 86, 88, 93, 142, 144, 178 Agesilau 2.2-4: 80

Alexandre 1: 237; 1.2: 163-164; 2-3: 161; 3: 153; 4: 92; 6: 160; 7: 153;

8: 154, 161, 164; 8.3: 159; 9: 153, 155; 10: 154; 11: 154; 14.2-6: 92; 15.8-9: 92; 16: 154; 16.7: 161; 19-29: 154; 21:91, 154, 155, 161; 35: 91; 43: 154; 47: 161; 47.9-10: 156; 49: 161; 50-52: 154; 67.8: 156, 162; 70: 154; 73-77: 154; 74.4-6: 80

António 4.2: 217; 15.1: 225; 25: 217; 26.1-6: 204, 217; 27.2-4: 209, 215; 8: 86, 94; 29: 205; 31.1-5: 225; 54: 216; 60.1: 199, 219; 61-68: 218; 66: 218; 69.1-2: 208; 71: 94, 205, 206; 74: 86; 74.2-3: 94; 75-76: 206; 76: 218; 76-78: 86; 76-78.1: 94; 77-79: 218; 79: 94; 79-87: 199; 84-86: 86, 94; 85.4-8: 199; 86: 206; 87.3: 225; 90.4: 221 Bruto 5.2-4: 180; 10.3: 202; 14.3: 202; 20.4: 179; 35.4: 202; 40.8: 202; 50: 208

Catão-Menor 8.1-2: 188; 24.1-3: 180; 33.7: 225; 64-73: 90

César: 66

10: 196; 14.8: 225; 25-27: 187; 27: 87, 180; 36: 180; 48.5: 94; 49: 94, 227;

49.2: 203; 49.10: 212; 62-67: 90; 63.5-6: 202; 63.8-11: 225; 64.4-6: 225 Cícero 29: 196

Coriolano 1: 177; 7: 174; 11.1: 176; 13: 174; 16: 176; 18: 174; 28: 176; 33: $175 ; 33-36: 91,92 ; 39: 176$

Crasso 8: 192, 193; 8.2: 192; 8.3: 195; 8-11: 188, 193; 9: 194; 11: 194; 36: 188

Díon: 151

Licurgo 14.8: 149 
Lúculo 34.1: 196

Marcelo 15-20: 144

Numa: 173

Otão: 230

Pelópidas 18-19: 151

Pompeio 2: 201; 31: 188; 47.10: 225; 53: 201; 77.3: 212; 77-79: 212; 78.1-7: 212; 79.1-5: 212; 80.8: 212

Publícola 16.6-9: 170; 17: 177, 230

Rómulo: 66

1-4: 89; 4.4-5: 90; 6: 90; 14.7-8: 168; 14.8: 172; 14-19: 89; 14-20: 143;

17.2-7: 170; 18.1: 170; 18.6: 172; 29: 173

Sólon 27.3-4: 150

Temistocles 14.4: 147

Teseu 12: 151; 14.1: 21; 15-20: 151; 18-20: 151

Moralia: 7, 32, 67, 68, 252, 270

Apophthegmata Lacaenarum 240G:149

Apophthegmata Laconica 225A: 149; 225B: 149; 225C-D: 150; 225D: 149

De Herodoti malignitate 866B: 148

De Iside et Osiride 351C: 218

De musica 1140F: 26

De sollertia animalium 969E: 31; 984A: 20; 984B-C: 28; 984D: 31; 984D-985F: 9; 984E: 31; 985B: 31

Mulierium virtutes 242F: 149

Parallela minora 306D: 149

Quaestiones convivales 704F-705A: 28

Septem sapientium convivium: 9, 28, 30, 32, 33

160D: 28-29; 160E-161B: 29; 160E-162B: 17, 27, 59-64; 161A-162B: 9;

161B-C: 29; 161D: 29; 161E-162A: 29-30; 162B: 30; 162C-F: 30; 162F-163A: 34; 163A-C: 9; 163A-D: 30; 163D: 31

Romance de Alexandre: 158

Sófocles: 159

Antígona 333-334: 159

\section{Suda}

A 1701: 26

A 3886: 25

Suetónio: $144,180,187$

César 82: 180

Nero 26: 211 
Tito Lívio: 11, 65, 66, 166, 176, 230

Desde a fundação da cidade 2.40: 176

\section{Vergílio}

Eneida 4.130-197: 169; 5.605-700: 159 
(Página deixada propositadamente em branco) 


\section{ÍNDICE REMISSIVO}

300: 148

A Batalha de Granico: 68

A ilha da Fortuna: 35, 41

A.D. - Anno Domini: 230

Abadía griega de San Nilo (Grottaferrata): 11

Aca Larência: 90

Academia de São Lucas: 84

Academia: 82, 83, 85, 88

Áccio: 198, 206, 211, 217, 222, 223, 224

Ácia: 186

Actos dos Apóstolos: 35

Ada Eurídice: 155

Adamo, Antonio: 229

Adriano: 183

Afrodite: 203, 204, 217, 229

Agar: 199

Agesilau: 79, 80

Akrotiri: 17

Alba Longa: 168, 172

Alberti, Leon Battista: 75-77, 79, 80

Alceu: 25

Alciato (Alciati), Andrea: 10, 37, 38, 39

Alemanha: 37

Alésia: 180

Alexander the Great: 152, 159

Alexander: 152, 161, 166

Alexandre acaba de domar Encéfalos: 68

Alexandre, o Grande: 11, 12, 79, 80, 89, 91, 92, 144, 152-166, 235, 236

Alexandre, o Grande e Campaspe no estúdio de Apeles: 92

Alexandre, o Grande e Roxana perante o túmulo de Aquiles: 91, 92

Alexandria: 215, 226

Amadio, Silvio: 151

Amores: 203

Amyot, Jacques: 32, 33, 66, 178

Anacársis: 30

Andrews, Harry: 154

Andrómeda: 36

Anfitrite: 20, 64

Angelopoulos, Theo: 152 
Aníbal: 230

Annibale: 230

Annis, Francesca: 219

Antígona: 159

Antiguidade Clássica: passim

Antonino: 189

Antonio e Cleopatra: 254

António: 12, 86, 87, 94, 144, 173, 178, 179, 186, 196-199, 201, 203-206,

208, 210-211, 215, 216, 218, 219, 221, 223, 225, 228, ver Marco António Antony and Cleopatra: 141, 197, 219, 221

Apiano: 144, 187

Ápio Cláudio: 35

Apolo Delfínio/Delphinius: 20

Apolo, Febo: 19, 20, 26, 29, 35, 43, 61

Apolodoro (servo de Cleópatra): 203, 218, 227

Aprà, Adriano: 230

Aquiles: 162, 164, 212

Aquirre, P.: 229

Aquitânia: 195

Ardisson, Giorgio: 212

Arion \& the Dolphin: 10, 45, 46, 47

Arion on the Dolphin: 44

Arion riding on a Dolphin: 44

Arion sur un cheval marin: 44

Arion: 44

Aríon: 9, 10, 17, 20, 24, 25, 26, 27, 28, 29, 30, 31, 32, 33, 34, 35, 36,

$38,39,40,41,42,43,44,45,46,47,58,59,60,61,63,64$

Aristobulo: 208

Aristóteles: 153, 156, 166

Aristóxeno: 151

Arriano: 160

Arsínoe: 209

Art Déco: 200

Artabazo: 155

Arte Nova: 200, 202

Artemidoro: 183

Artemísia de Halicarnasso: 147

Ashmolean Museum (Oxford): 44

Ásia: 203

Astérix et Obélix: 228

Astérix: 185, 220 
Átalo: 155

Átamas: 35

Atenas: 19, 23, 147, 150, 157, 158, 226

Atenienses: 145

Ática: 18, 147

Aufídio: 141, 176

Augsburgo: 37

Aurispa, Giovanni: 33

Babilónia: 154, 161

Baciato, Lêntulo: 189, 191, 192, 193, 195

Backy, Don: 230

Bagoas: 156, 162

Baker, Diane: 146

Baker, Stanley: 155

Bamber, David: 186

Banquete de Cleópatra: 86

Bara, Theda: 199

Barcelona: 172

Barnes, Joanna: 192

Barrie, Amanda: 220

Barsine: 154, 155, 158, 162

Barthes, Roland: 182

Batalhão Sagrado: 150

Bates, Alan: 188

BBC: 221

Bellucci, Monica: 228

Benét, Stephen Vincent: 142

Ben-Hur: 166, 213, 222

Bennett, Jill: 184

Benson, Frank R.: 185

Bernhardt, Curtis: 151

Bianchi Ferrari, Francesco: 44

Bianor: 27, 39

Bíblia: 13

Biopics: 141, 161, 184, 232

Blasetti, A.: 188

Blood and Sand: 188

Bloom, Claire: 154

Boccaccio: 86, 93

Boccia, Tanio: 185

Borbely, Csaba: 188 
Bosch, Francisco: 162

Boucher, François: 44

Bouchet, Louis-André-Gabriel: 90

Bouguereau, William-Adolphe: 44

Bouillon, Pierre: 90

Bower, Dallas: 185

Boyd, Stephen: 213

Bradley, David: 184, 185, 221

Brandauer, Klaus Maria: 185

Brando, Marlon: 181, 182

Brasil: 225

Brescia-Müller, Alfonso: 230

Bressane, Júlio: 223

Brett, Leonard: 185

Brignone, Lilla: 175

Britânia: 220

British Museum (Londres): 27, 34

Broadway: 214

Brogi, Sebastiano: 229

Bruegel, Pieter, o Velho: 34

Bruto: 144, 178-183, 186

Bruxelas: 35, 66, 67f

Bucéfalo: 160

Burge, Stuart: 183, 221

Burr, Raymond: 208

Burton, Richard: 152, 158, 214, 215

Butler, Gerard: 141, 148

Byrne, Gabriel: 152

Byron, Jean: 210

Cacoyannis, Michaël: 167

Caesar: 185

Caesar and Cleopatra: 185, 207, 219

Caesar's Prisoners: 185

Calcagno, Giovanni: 187

Calhern, Louis: 181

Calígula: 229

Calpúrnia: 178, 182, 184, 186, 201, 220, 225

Cambray, Fréart de: 82

Camera degli Sposi (Camera Picta): 33

Canale, Gianna Maria: 196

Capela Sistina: 35 
Cápua: 191

Cária: 147

Carlos V: 36, 37

Carmiana: 199, 206, 210, 219, 221, 223, 227

Camuccini, Vincenzo: 90, 91

Carry on Cleo: 210, 219

Carulla, Carmen: 154

Casca: 183

Cassandro: 80

Cassarino, Antonio: 33

Cássio: 182, 186

Castle, John: 221

Castle, William: 208, 210, 211

Catâo Menor: 89, 90, 178, 186, 188

Catulo: 219

César e Cleópatra: 66

Cesarino: 211

Chamberlain, Richard: 183

Chaplin, Saul: 142

Charleson, Ian: 152

Chartres, Bernard de: 72

Chastain, Jessica: 141

Cícero: $75,151,186$

Cidno: 203

Cimbro: 178

Cípselo: 58

Circe: 204, 205

Cláudia: 192

Clay, Nicholas: 152

Clélia: 177

Cleopatra II - Legend of Eros: 229

Cleopatra: 144, 180, 197, 201, 202, 212-214, 219, 224, 228, 229

Cleópatra: 12, 35, 66, 87, 89, 93-95, 141, 144, 153, 155, 173, 178, 179, 180, 187, 196-201, 203-208-212, 214-216, 218-221, 223-230, 236

Clítias: 18

Clódia: 196

Cnossos: 17

Colbert, Claudette: 200-202, 204, 220

Collins, Joan: 212

Condon, Kerry: 186

Constantino: 217 
Contemporaneidade: 91

Cooley, Isabelle: 219

Cooper, Stuart: 230

Corbucci, Sergio: 166-168, 172, 173, 196

Corinto: 24, 25, 26, 45, 58, 59, 61, 63

Coriolano, eroe senza pátria: 174, 176

Coriolano perante a súplica de sua mãe: 92

Coriolano: 12, 89, 91, 92, 144, 145, 173-176, 236

Coriolanus: 141

Cormack, Bartlett: 202

Corneille: 230

Cornélia: 187

Cornélio Nepos: 11

Cortona, Pietro de: 84

Cossa, Pietro: 199

Cottafavi, Vittorio: 210, 211, 213

Courbet, Gustave: 225, 226

Cox, Brian: 141

Cranham, Kenneth: 186

Crasso: 188, 189, 192, 195, 196

Creso: 150

Cressoy, Pierre: 176

Crisa: 20

Cristal, Linda: 211

Cristo Salvador: 23, 43

Cruserius, Hermannus: 32

Cúrcio, Quinto: 160

Cúrcio: 168

Curtis, Tony: 189, 195

D'Amato, Joe: 229

Da Pintura: 75, 76

Damon and Pythias: 151

Dânae: 36

Dario: 91, 154, 161, 166

Darrieux, Danielle: 153

David: 193

Dawson, Rosario: 162

De casibus uirorum ilustrium: 86

De Mulieribus Claris: 93

De Viris Illustrium: 81

DeKnight, Steven: 188 
Delfos: 20

Delphinus (Delfim, Golfinho), constelação: 42

DeMille, Cecil B.: 200, 201, 202, 204-206, 210, 216, 220

Demóstenes: 158

Des cas des nobles hommes et femmes: 86

Deux heures moins le quart avant Jésus Christ: 185

Dexter: 174

Dez Livros de Arquitectura: 78

Diana: 173, 183

DiCaprio, Leonardo: 153

Dido: 169

Diéneces: 149

Dieterle, William: 208

Diógenes e Alexandre: 92

Dionísio de Siracusa: 151

Dioniso: 164, 203, 217, 223, ver Diónisos

Diónisos: 21, 22, 23, ver Dioniso

Donen, Stanley: 142

Dorffman, Jacques: 185, 187

Dornhelm, R.: 188

Douglas, Kirk: 189, 190, 193

Draba: 193

Ducas, Demetrios: 32

Duncan, Lindsay: 151, 179, 186

Dürer, Albrecht: 34, 39, 41

Durkin, Grace: 206

Easton, Jane: 209

Edel, Uli: 185

Édipo: 164

Edwards, James Gordon: 200

Egan, Richard: 146

Egipto: 93, 94, 141, 196, 198-200, 204, 205, 212, 220, 224, 227

El rapto de las Sabinas: 172

Emblematum liber (Emblematum libellus, Emblemata): 37, 39

Empire: 180, 186

Énalo: 30, 31

Eneias: 169

Eneida: 159, 169

English National Opera: 45

English, Jonathan: 151

Entrada de Alexandre em Babilónia: 91 
Epic film: 146, 183, 184, 189, 232

Epiro: 153

Erasmo de Roterdão: 32

Erétria: 18

Ergotimo: 18

Espanha: 35, 157, 222

Esparta: 148, 149

Espártaco: 12, 144, 187-191, 193-196, 229, 236

Espartanos: 145, 149, 150

Ésquines: 158

Estatira: 154, 161, 162

EUA: 165, 193, 198, 213

Eurídice: 155

Europa, princesa: 36

Europa: 37, 67, 85, 143, 179

Exéquias: 21,22

Fábio Máximo: 11

Fabiola: 188

Falabella, Miguel: 224, 225

Farrar, David: 146

Farrell, Colin: 152, 157

Fast, Howard: 190

Fáustulo: 89

Fellini, Federico: 167, 214

Ferroni, Giorgio: 174, 176

Ferzetti, Gabriele: 230

Fiennes, Ralph: 141, 174

Filipe Arrideu: 155

Filipe: 152, 153, 155, 160, 164

Filipos: 178, 183, 184

Finch, Peter: 213

Flandres: 36, 67

Flávio Josefo: 202, 209

Flemming, Rhonda: 207, 209

Florença: 32, 81

Foch, Nina: 189, 192

Fogo do Céu: 163

Fortuna: 35, 36

Fox: 145, 213, 219

França: 85, 92

Francisco de Siena: 11 
Freda, Riccardo: 188

Frenkel, Theo: 185

Ftatatita: 207, 208, 227

Gaius Iulius Caesar: 179

Gallone, C.: 230

Garcia, Bruno: 224

Gardner, Helen: 198

Garrani, Ivo: 196

Garson, Greer: 182

Gaugamelos: 161, 164

Gauleses: 87

Gautier, Théophile: 200,

Gavin, John: 187, 189, 192

Génova: 81

George, Margaret: 222

Gielgud, John: 182, 184

Giovagnoli, Raffaello: 188

Girotti, Massimo: 168, 188

Giulio Cesar, il conquistatore delle Gallie: 185

Giulio Cesare contro i pirati: 185

Giulio Cesare: 185

Glover, Julian: 152

Gora, Claudio: 196

Górdio (Turquia): 18

Górgidas: 150

Gorgo, irmão de Periandro: 9, 28, 29, 30, 59, 60, 63, 64

Gorgo, rainha de Esparta: 148

Goscinny: 185, 220

Gossart, Jan: 35

Gout, Alberto: 172

Graças: 203, 204

Granico: 154, 161

Graphische Sammlung Albertina (Viena de Áustria): 34

Graves, Rupert: 222

Grécia: 9, 18, 25, 145, 147, 150, 157, 159, ver Hélade

Gregos: 18, 20, 23, 78, 145, 149, 159

Grieco, Sergio: 185

Guazzoni, Enrico: 179, 180, 198

Guerra Fria: 146, 190

Guiness, Alec: 213

Gwynne, Haydn: 186 
Habsburgo: 36

Haggard, H. Rider: 200

Hamer, Mary: 94

Harrison, Rex: 215

Hayward, Susan: 212

Hayworth, Rita: 209

HBO: 179, 186, 226

Headey, Lena: 148

Hebreus: 205

Hécuba: 35

Heféstion: 152, 156, 161, 162

Hefestos: 35

Hélade: 145, 160, ver Grécia

Helen Gardner in Cleopatra: 197

Helen Gardner Players: 197

Helena: 189, 192

Heller, Bruno: 186, 187

Henley, Alice: 187

Henry, Guy: 186

Henson, Jim: 151

Hepburn, Audrey: 212

Héracles: 164, 217

Herculano: 85

Hércules: 40, 42, 221

Herodes-o-Grande: 202, 208

Hersília: 168, 169

Hesíodo: 30, 31

Hesme, Annelise: 161

Heston, Charlton: 184, 213, 220-222

Hímera: 25

Hinds, Ciarán: 179, 186

História de Alexandre, o Grande: 68

História de Júlio César: 67

História de Marco António: 68

História de Rómulo e Remo: 66

Holanda, Francisco de: 78, 80

Holland, Philemon: 32

Hommes célèbres d'après Plutarque (História grega ou Homens célebres segundo Plutarco): 66, 67

Horácio Cocles: 170

Hordern, Michael: 158 
Hostílio: 168, 172

Houseman, John: 180

Huillet, Danièle: 230

Hunter, Kathryn: 227, 228

Idade de Ouro: 72

Idade Média: 36, 42, 65, 71, 72, 85, 91

Idos de Março: 90

Il colosso di Roma: 177

Il figlio de Spartacus: 196

Iliada: 160, 164

Império Romano: 88

Império Sacro-Romano: 81

International Plutarch Society: 17

Intervenção das Mulheres Sabinas: 89

Iras: 206, 210, 219, 227

Ísis: 218

Isso: 154

Itália: 10, 20, 58, 59, 61, 159, 179, 191, 213

James, Sidney: 220

Janssens, Victor: 66

Jesus de Nazaré: 194

Jogos Fúnebres: 163

Johnson, Karl: 186

Johnson, Lex: 172

Jolie, Angelina: 141, 162

Jonas: 23

Jones, Barry: 153

Júlia: 168,169

Julieta: 176

Júlio César: 11, 12, 66, 87, 89-91, 93, 94, 144, 173, 178-181, 183-187, 189, 192, 196, 197, 200-203, 206-208, 212, 213, 215, 216, 219, 220, 223-225, 227, 234-236

Julius Caesar: 141, 178, 183-185, 219, 221, 228

Júpiter: 41, 42

Karlson, Phil: 152, 155

Keel, Howard: 142, 143

Kennedy, J. F.: 193

Kerr, Deborah: 182

Kidman, Nicole: 153

Kilmer, Val: 162

Kubrick, Stanley: 187-190, 194, 195 
Kunsthistorisches Museen (Viena): 19

Kureopatora: 229

L'enlèvement des Sabines: 172

L'origine du Monde: 225

La battaglia di Maratona: 150

La dolce vita: 214

Lady Flora: 201

Lady Leda: 201

Lady Vesta: 201

Lambert, Christopher: 185, 187

Landi, Aldo Bufi: 176

Langetti, Giovanni Battista: 92

Lapotaire, Jane: 152, 221

Laughton, Charles: 189, 192

Le Brun, Charles: 68, 82, 91

Le legioni di Cleopatra: 210, 213

Lee, Christopher: 183

Leigh, Vivien: 184, 207

Lenine: 191

Leone, Sergio: 167, 168

Leónidas: 144-146, 148, 149, 229

Lépido: 186

LeRoy, Mervyn: 181, 188, 189

Les yeux ne veulent pas en tout temps se fermer, ou Peut-être qu'un jour Rome se permettra de choisir à son tour: 230

Lésbia: 219

Lesbos: 24, 25, 26, 29, 45, 47

Leto, Jared: 162

Leyniers, Daniel II: 66

Leyniers, Urbain: 66

Liebknecht, Karl: 191

Liga Espartaquista: 191

Lisi, Virna: 168

Lisícrates: 22

Lívia: $175,176,186$

Loren, Sophia: 210, 211, 213

Los Honores (As Honras): 35, 36, 37

Lowell, Robert: 33

Lucas, São: 84

Lucílio: 208

Luçon, Mestre de: 10, 86 
Luhrmann, Baz: 152

Luís XIV: 92

Lundigan, William: 208

Lupercais: 171,172

Lupo, Alberto: 174

Luxemburgo, Rosa: 191

MacDonald, W. J.: 186

Macedónia: 79, 91, 152, 153, 161, 163

Madden, John: 151

Maedi: 195

Magna Grécia: 18, 25

Maneirismo: 81

Mankiewicz, Joseph L.: 144, 180, 181, 183, 207, 210, 212, 214, 216, 219,220

Mantegna, Andrea: 33

Manúcio, Aldo: 32

Mar Egeu: 27

Marais, Jean: 173

Maratona: 151

Marc Anthony: 229

March, Fredric: 153

Marchal, Georges: 211

Marco António: 12, 89, 93, 94, 181, 182, 184, 200, 213, 217, 220, 221, 224, ver António

Marco: 176

Marshal, Lyndsey: 187, 226

Marte: 173

Marte e Reia Silvia: 89

Marx, Karl: 190

Mason, James: 152, 181, 182

Maté, Rudolph: 145, 150

Mattoli, Mario: 210

Mature, Victor: 230

Mayo, Alfredo: 211

McCarthy: 192

McKidd, Kevin: 186

Medeia: 151, 164

Mediterrâneo: 17

Medos: 195

Megalexandros: 152

Mémnon: 155, 156 
Memoirs of Cleopatra: 222

Menénio: 141

Menzies, Tobias: 179, 186

Mercer, Johnny: 142, 143

Messalina: 210, 211, 229

Metimna: 9, 24, 27, 28, 58

Michael, Gertrude: 201

Milius, J.: 186

Miller, Frank: 148

Min: 225

Minervini, Angela: 175

Minghella, Anthony: 151

Minotaur: 151

Minotauro: 151

Mission Cléopâtre: 228

Modernidade: 72

Modi, Sohrab: 152

Moisés: 205

Montanha Sagrada: 169

Moore, Roger: 173

Moreau, Gustave: 44, 45

Moreau, Jeanne: 166

Morte de António e Cleópatra: 86

Múcio Cévola: 177, 230

Munda: 184

Musas: 26

Museo Nazionale del Palazzo di Venezia (Roma): 42

Museo Nazionale di Villa Giulia (Roma): 28

Museu de Francisco Tavares Proença Júnior (Castelo Branco): 67

Museu de Lamego: 68

Museu do Hermitage (S. Petersburgo): 20

Museu do Louvre (Paris): 19

Museu Nacional (Atenas): 17, 19, 23

Museu Nacional de Arte Antiga (Lisboa): 40, 42, 43, 68

Museu Nacional Machado de Castro (Coimbra): 40

Museum of Fine Arts (Boston): 27

Museus do Vaticano (Roma): 19

Napoleão Bonaparte: 85

Nápoles: 216

Negrini, Alessandra: 224

Neil, Hildegard: 221 
Nereides: 203, 204

Nereu: 64

Neri, Rosalba: 175

Nero: 211, 229

Nilo: 210

Nisca: 211

Nord, Paul: 150

North, Alex: 189, 215

North, Thomas: 32,178

Nova Iorque: 26, 33, 197

Novelli, Amleto: 179

Novelli, Antony: 198

Numa Pompílio: 173

O Jovem Persa: 163

O sacrificio de Aristides: 67

O Triunfo de César: 91

Ocidente: 32, 226, 235

Octávia: 186, 199, 221, 225

Octávio: 87, 89, 183, 186, 203, 211, 221, 222

Oh! Oh! Cleopatra: 185

Olímpia: 152, 153, 155, 160, 161, 164

Olivier, Laurence: 189, 192, 195, 213

Ônfale: 217,221

Oriente: 159, 204, 226

Os Prazeres de Cleópatra: 229

Os últimos dias de Pompeia: 169

Óscar: 142, 181, 189, 192, 219

Osíris: 153,218

Otâo: 144,230

Othon: 230

Palácio dos Duques de Bragança (Vila Viçosa): 68

Palácio Ducal de Mântua: 10, 33

Palácio Nacional da Ajuda (Lisboa): 68

Palácio Nacional de Mafra: 68

Palácio Nacional de Sintra: 67

Palacio Real de La Granja de San Ildefonso, Museo de Tapices (Segóvia): 35

Palazzo Vitelli alla Cannoniera (Città di Castello): 11

Pani, Corrado: 212

Pantho: 79

Papado: 81

Paris: $19,32,37,39,44$ 
Partido Comunista: 156

Pascal, Gabriel: 184, 207, 227

Pasolini, Pier Paolo: 167

Pastrone, Giovanni: 185

Patrick, Anna: 187

Património Nacional de Espanha: 35

Pátroclo: 162

Paul, Gene de: 142

Paupertas (Pobreza): 35

Peloponeso: 26, 62

Pélops: 64

Península Itálica: 81

Peplum: 151, 166, 167, 169, 174, 177, 181, 183, 189, 196, 214, 232, 235

Periandro: 24, 25, 26, 28, 29, 30, 45, 58, 59, 61, 64

Perotti, Niccolò: 33

Perry, P.: 228

Persas: 145,146

Persépolis: 157

Perseu: 36

Pérsia: 148, 149, 156, 159, 166

Petit Palais, Musée des Beaux-Arts (Paris): 44

Petit, Pascale: 212

Petrarca: 81

Phelps, Eleanor: 206

Piazza Armerina, Villa Romana del Casale: 31

Pintor de Berlim: 19, 26

Pintor de Brigos: 27

Pintor de Cleófrades: 27

Pintor de Edimburgo: 19

Pirkis, Max: 186

Pítaco: 30

Píton: 29

Plummer, Christopher: 166

Polícrates: 36

Pomoerium: 169

Pompeio: 144, 178, 186, 188, 201, 212, 225, 236

Pompeios: 85

Pontipee, Adam: 142

Popeia Sabina: 200, 220

Poppea, una prostituta al servizio dell'impero: 230

Pórcia: 178, 182, 184 
Portugal: 67

Poséidon: 20, 27, 64

Pottier, Richard: 172

Poussin, Nicolas: 82, 84, 92

Powell, Jane: 143

Princeton University Art Museum: 44

Prometeu: 164

Ptolemeu Auletes XII: 209, 210

Ptolemeu: 152, 159, 165, 209, 212

Publícola: 175

Pulão, Tito: 186,

Purefoy, James: 186

Queroneia: 148, 150, 153, 221, 229, 236

Quintiliano: 75

Quo Vadis?: 160, 166, 188, 189

Rafael (Raffaello Sanzio da Urbino): 35

Rains, Claude: 184, 207

Rapto das Sabinas: 89

Ray, Jane: 47

Redgrave, Vanessa: 141

Reeves, Steve: 167, 196

Regan, Jane: 201

Reia Sílvia: 167, 168

Reino Unido: 213

Remo: 36, 66, 89, 90, 167, 169, 170, 172

Renascimento: 32, 42, 65, 71, 72, 81, 89, 93, 143, 184

Renault, Mary: 163

Revolução Francesa: 85

Reydams, Henri II: 66

Richardson, Ralph: 146

Rigg, Diana: 183, 184

Robards, Jason: 183

Roberts, Florence: 201

Robson, Flora: 207, 208

Roddam, Franc: 222

Roma: 42, 65, 66, 67, 84, 89, 91, 92, 166, 168-170, 172-176, 182, 192, 212, 215, 217, 220, 224, 229

Romanos: 145, 174, 176, 190

Romantismo: 89

Rome: 179, 186, 187, 226, 228

Romeu: 176 
Romolo e Remo: 166, 167

Rómulo: 12, 36, 66, 89, 90, 144, 145, 166, 167, 169, 170, 172, 173

Rossen, Robert: 152, 153, 156-161

Rotari, Pietro António: 92

Roth, Alec: 10, 45

Roxana: 154, 162, 165

Royer, Lionel-Nöel: 87

Rubens, Pieter Paulo: 89

Ruvinskis, Wolf: 172

Ryland, Celia: 201

Sabbatini, Enrico: 222

Sabinas: $12,142,168,172$

Sabinos: 168

Sacchi: 84

Safo: $25,44,45$

Salamina: 147

Salomão: 40

Salome: 208

Samos: 36

Samson and Delilah: 160, 202

Santley, Joseph: 185

Santoro, Rodrigo: 148

Sapho sur le rocher: 45

Sardo, Samuela: 228

Sardou, Victorien: 200

Schildkraut, Joseph: 202

Scipione l'Africano: 230

Scott, Gordon: 167, 174, 177

Seleuco: 35

Sernas, Jacques: 168

Serpent of the Nile: 207

Servília: 179, 186

Sete Sábios: 25

Seth, Vikram: 10, 45, 46, 47

Seven Brides for Seven Brothers: 142, 172

Sevilla, Carmen: 221

Shakespeare, William: 32, 141, 173, 174, 176, 178-181, 183-186, 197, 198, 202, 208, 218, 219, 221, 226, 236

Shatner, William: 152, 158

Shaw, George Bernard: 185, 207, 227

Showtime: 175 
Sicília: 31, 58, 64

Sicínio: 174, 176

Siena: 7

Sikandar: 152

Silvestro, R.: 228

Simmons, Jean: 189, 192

Sims, Joan: 220

Siracusa: 18,151

Six, técnica de: 19

Snyder, Zack: 148

Sogni erotici di Cleopatra: 228

Solari, Laura: 168

Sólon: 30,150

Sordi, Alberto: 211

Spartaco: 188

Spartacus: 161, 187-189, 195, 215

Spartakus: 191

Squire, William: 158

Staatliche Antikensammlungen (Munique): 21

Staatliche Museen (Berlim): 18

Star system: 183

Stephanus, H. (Henri Etienne): 32

Stevenson, Ray: 186

Stone, Harold J.: 193

Stone, Oliver: 152, 153, 156-158, 160-166

Straub, Jean-Marie: 230

Strode, Woody: 193

Susa: 154,157

Tácio, Tito: 168

Tarento: 26, 27, 58, 59

Tarpeia: 170,171

Tarso: 203, 210, 216, 217, 223, 224

Tarzan: 167

Taylor, Elizabeth: 207, 212-215

Tebas: 21

Teixeira, Virgílio: 159

Telémaco: 31

Temístocles: 144-147

Ténaro (Matapan): 26, 27, 28, 58, 59, 64

Tera (Santorini): 17

Termópilas: 12, 145-149, 151 
Terpandro: 26

Teseo contro il Minotauro: 151

Teseu: 151

Téspios: 145

Tezuka, O.: 229

The 300 Spartans: 145

The Cleveland Museum of Art (Ohio): 44

The Fall of the Roman Empire: 213, 222

The Metropolitan Museum of Art (Nova Iorque): 26

The Notorious Cleopatra: 228

The Robe: 160

The Search for Alexander the Great: 152

The Sign of the Cross: 200, 220

The Slave: 196

The Sobbin' Women: 142

The Spread of the Eagle: 174, 186

The Storyteller: 151

The Ten Commandments: 160, 202, 205

Theseus and the Minotaur: 151

Three Men of War in a Tempest Sailing to the Right, with Arion: 34

Tiepolo, Giovanni Battista: 92

Torresanus, Andreas: 32

Tourjansky, Victor: 210

Tourneur, Jacques: 150

Trasibulo: 58

Tróia: 78

Troianos: 159

Trumbo, Donald: 190

Uderzo: 185, 220

Ulisses: 19, 31, 204, 205

Una regina per Cesare: 210

University House (Camberra): 18

Ustinov, Peter: 189, 192

Útica: 186

Valéria: 175

Valério Máximo: 11

Valle, Anna: 228

Valle, Ricardo: 156

Van Aelst, Pieter: 35

Van Orley, Bernard: 35

Vanoni, Ornella: 170 
Varela, Leonor: 222, 228

Varínia: 189, 192-195

Varínio, Públio: 194

Vaughn, Robert: 183

Veneza: 32, 81

Vercingétorix: 87, 187

Vercingétorix: 87, 187

Vercingétorix: 185, 187

Vercingétorix rende-se a César: 87

Vergília: 141, 176

Vesta: 173, 201

Vibert, Ronan: 186

Victoria and Albert Museum (Londres): 45

Vidali, Enrico: 188

Vinci, Leonardo da: 76, 80

Virgínia: 175, 176

Visnjic, Goran: 188

Vitrúvio:78

Volscos: $174-176$

Volúmnia: 141, 175

Voreno, Lúcio: 186, 227

Wakefield, Anne: 147

Walker, Polly: 186

Western: 169, 171, 209

Whitfield, Andy: 188

Wilcoxon, Henry: 200

William, Warren: 200

Williams, Kenneth: 220

Winckelmann, Johann Joachim: 85

Woods, Simon: 186

Xerxes: 145, 146, 148, 149

Xylander, Wilhelm Holtzman: 32

Yamamoto, E.: 229

Yanne, Jean: 185

Zacintos: 31

Zancle: 18

Zeus: 21, 158, 164

Zeus Ámon: 158

Zeus Nemeu: 30

Ziegfeld: 201 
(Página deixada propositadamente em branco) 


\section{COLECÇÃo AUTORES \\ Gregos E LATINos - Série ENSAIOS}

1. Carmen Soares, José Ribeiro Ferreira e Maria do Céu Fialho: Ética e Paideia em Plutarco (Coimbra, $\mathrm{CECH}, 2008)$.

2. Joaquim Pinheiro, José Ribeiro Ferreira e Rita Marnoto: Caminhos de Plutarco na Europa (Coimbra, CECH, 2008).

3. Cláudia Teixeira, Delfim F. Leão and Paulo Sérgio Ferreira: The Satyricon of Petronius: Genre, Wandering and Style (Coimbra, CECH, 2008).

4. Teresa Carvalho, Carlos A. Martins de Jesus: Fragmentos de um Fascinio. Sete ensaios sobre a poesia de José Jorge Letria (Coimbra, CECH, 2009).

5. Delfim Ferreira Leão, José Ribeiro Ferreira e Maria do Céu Fialho: Cidadania e Paideia na Grécia Antiga (Coimbra, CECH, 2010).

6. Maria de Fátima Silva and Susana Hora Marques: Tragic Heroines on Ancient and Modern Stage (Coimbra, $\mathrm{CECH}, 2010)$.

7. Ália Rosa Rodrigues, Carlos A. Martins de Jesus, Rodolfo Lopes: Intervenientes, Discussão e Entretenimento, No Banquete de Plutarco (Coimbra, CECH, 2010).

8.Luísa de Nazaré Ferreira, Paulo Simóes Rodrigues e Nuno Simóes Rodrigues: Plutarco e as Artes. Pintura, Cinema e Artes Decorativas (Coimbra, CECH, 2010). 
(Página deixada propositadamente em branco) 

OBRA PUBLICADA

COM A COORDENAÇÃO

CIENTÍFICA

$\mathrm{ECH}$

- U

C •

IMPRENSA DA ENIVERSIDADE DE COIMBRA

U 